\title{
Comprehensive Study of Drift From Mechanical Draft Cooling Towers \\ Final Report
}
N. S. Laulainen
R. O. Webb
K. R. Wilber
S. L. Ulanski

September 1979

Prepared for the U.S. Department of Energy under Contract EV-76-C-06-1830

Pacific Northwest Laboratory Operated for the U.S. Department of Energy by Battelle Memorial Institute 


\title{
NOTICE
}

This report was prepared as an account of work sponsored by the United States Government, Neither the United States nor the Department of Energy, nor any of their employees, nor any of their contractors, subcontractors. or their employees, makes any warranty, express or implied, or assumes any legal liability or responsibility fot the accuracy, completeness or usefulness of any information, apparatus; product ot process disclosed, or represents that its use would not infringe privately owned rights.

The views, opinions and conclusions contained in this report are those of the contractor and do not necessarily represent those of the United States Government or the United States Department of Energy.

\author{
PACIFIC NORTHWEST LABORATORY \\ operated by \\ BATTELLE \\ for the \\ UNITED STATES DEPARTMENT OF ENERGY. \\ Under Contract EY-76-C-06-7830.
}

\begin{tabular}{|c|c|}
\hline \multicolumn{2}{|c|}{$\begin{array}{c}\text { Printed in the United States of An } \\
\text { Avaliable from } \\
\text { Nationaf Technical Information Se } \\
\text { United States Department of Com } \\
5285 \text { Port Royal Road } \\
\text { Springfield. Virginia 22151 }\end{array}$} \\
\hline e: Printed Copy & - Microl \\
\hline -Pages & $\begin{array}{l}\text { NTIS } \\
\text { Seliing Price }\end{array}$ \\
\hline $001-025$ & 54.00 \\
\hline $026-050$ & $\$ 4.50$ \\
\hline $051-075$ & $\$ 5.25$ \\
\hline $076-100$ & $\$ 6.00$ \\
\hline $101-125$ & $\$ 6.50$ \\
\hline $126-150$ & 57.25 \\
\hline 151.775 & $\$ 8.00$ \\
\hline $176-200$ & $\$ 9 . \infty$ \\
\hline $201-225$ & 59.25 \\
\hline $226-250$ & 59.50 \\
\hline 251.25 & 510.75 \\
\hline $276-300$ & 511.00 \\
\hline
\end{tabular}


PNL -3083

UC -12

\subsection{0}

COMPREHENSIVE STUDY OF DRIFT FROM MECHANICAL DRAFT COOL ING - TOWERS

FINAL REPORT

by

N. S. Laulainen

R. 0. Webb(a)

K. R. Wilber(a)

S. L. Ulanski(b)

September 1979

Pacific Northwest Laboratory

Richland, Washington 99352

Work performed for the U. S. Department of Energy under Contract EY-76-C-06-1830

\footnotetext{
(a) Environmental Systems Corp., Knoxville, TN

(b) James Madison Univ., Dept. of Geology, Harrisonburg, VA 


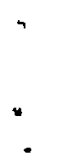

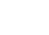




\section{SUMMARY}

A comprehensive experiment to study drift from mechanical draft cooling towers was conducted during June 1978 at the Pacific Gas and Electric Company's (PG\&E) Pittsburg Power Plant located at Pittsburg, California. The objective of the experiment was to establish a data base for use in drift deposition model validation. This objective was met by the simultaneous measurement of cooling tower source emission parameters, meteorological variables and drift deposition patterns during seven of eight test runs. In this report, the results from six of these test runs are presented and discussed.

Environmental Systems Corporation (ESC) conducted the source characterization measurements. These measurements included cooling tower emission parameters such as updraft velocity and temperature profiles, liquid and mineral mass drift emission rates, and drift droplet size distributions. ESC also provided $\mathrm{plant}$ and cooling tower operational parameters, obtained either from its own measurement program or from the PG\&E plant log.

Pacific Northwest Laboratory (PNL) carried out the meteorological and surface drift deposition measurements. The meteorological measurements included wet- and dry-bulb temperature and wind speed and direction on a continuous basis from sensors on a $10 \mathrm{~m}$ tower and on antermittent basis from an instrumented tethered balloon system. The latter measurements provided information on the vertical structure of temperature, moisture and mass transport. Surface deposition measurements included both droplet and bulk mineral mass deposition rates.

Substantial variation in drift emissions were noticed. Large day-today variations for a given cell and large cell-to-cell variations were observed. Because of the large variability of drift mass emission a representative emission rate per cell was calculated by ESC using a weighted average based on both the pretest survey and the detailed characterization of seven cells. The problem of deriving a total droplet emission spectrum and rate from one or two towers is complicated and the modeler must decide on the amount of detail he needs to satisfactorily predict downwind deposition patterns. 
Assuming that ESC's averaging procedure was reasonable, the emission rate per cell was found to be $4.8 \mathrm{~g} \mathrm{~s}^{-1}$. If all $26 \mathrm{cells}$ were operating the total emission rate would be $124 \mathrm{~g} \mathrm{~s}^{-1}$. The latter value may be uncertain by anywhere from 30 to $70 \%$, depending upon the validity of the averaging procedure. With a total circulating water flow rate of $20 \mathrm{~m}^{3} \mathrm{~s}^{-1}$, the $124 \mathrm{~g} \mathrm{~s}^{-1}$ emission rate corresponds to a drift fraction of $0.0006 \%$ compared to the guaranteed drift rate of $0.004 \%$.

Meteorological conditions during the drift study were characterized by relatively high winds, warm temperatures and moderate humidities. The relatively high winds increased the uncertainty in the measured deposition patterns. In spite of the large (factor of 2 or 3) uncertainty in the measured deposition rates, preliminary calculations of drift deposition rates by ESC using its own model and the source and meteorological data described above are in agreement with each other for test run 1, 6-16-78.

Although the present study did not encompass as wide a range of meteorological conditions as would be required for complete validation of various drift models, it has contributed a unique set of data for that purpose. 


\section{CONTENTS}

SUMMARY •

TABLES • • • • • • • • • • • • • • • • • • • • • vi

FIGURES • • • • • • • • • • • • • • • • • • • • • ix

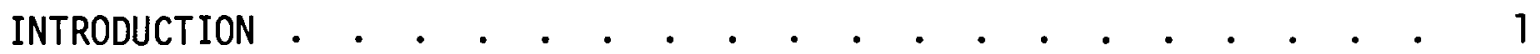

CONCLUSIONS AND RECOMMENDATIONS • • • • • • • • • • • • • • • • •

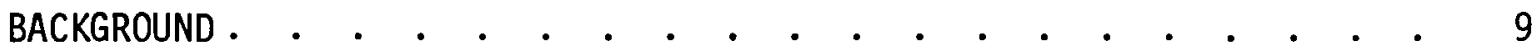

SITE EVALUATION AND SELECTION • • • • •

PG\&E PITTSBURG POWER PLANT DESCRIPTION • • • • • • • • • • • 11

PREL IMINARY TESTS •

EXPERIMENTAL •

SOURCE CHARACTERIZATION . . . . . . . . . . . . . . . 20

METEOROLOGY • • • • • • • • • • • • • • • • • • • • 29

DRIFT DEPOSITION • • • • • • • • • • • • • • • . 34

RESULTS • • • • • • • • • • • • • • • • • • • • • • •

SOURCE CHARACTERIZATION . • . • . . . • . . . . . . . . . 51

METEOROLOGY • • • • • • • • . • . • • • • . . . 68

DRIFT DEPOSITION • • • • • • • • • • • • • • • • • •

Droplet Deposition Patterns • • • • • • • • . • . 71

Mineral Ion Deposition Patterns . . . . . . . . 92

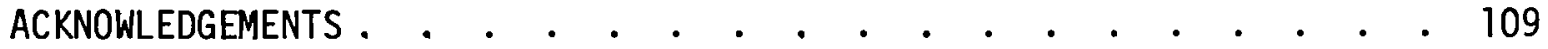

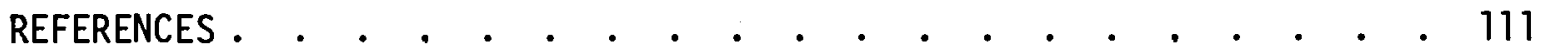

APPENDIX A: COOLING WATER MINERAL ANALYSIS . . • . • . • . .

APPENDIX B: SAMPLING STATION IDENTIFICATION

APPENDIX C: METEOROLOGICAL SUMMARIES • • • • • • • • • • • •

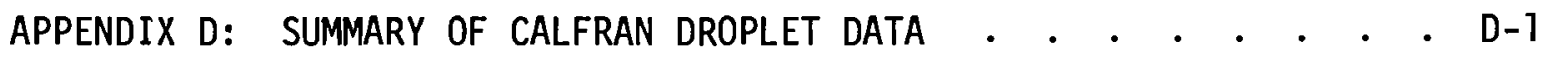

APPENDIX E: DEPOSITION LISTINGS • • • • • • • • • • • • •

1. Droplet Data • • • • • • • • • • • • E-1

2. Mineral Ion Data . . . . . . . . E E-46 
. 


\section{LIST OF TABLES}

\section{1}

3

4

5

6

7

8

9

10

11

12

13

14

Summary of Test Runs and Average Meteorological

Conditions During the June 1978 Pittsburg

Drift Study.

Summary of ESC Data Acquisition for the June 1978

Pittsburg Drift Study . . . . . . . . . . . 26

Downwind Sampling Station Identification and

Location Relative to Both Cooling Towers . . . . . 36

ESC Stain Shape Classification . . . . . . . . 45

Plant Operational Data (ESC). . . . . . . . . 52

Cooling Tower Operational Data (ESC) . . . . . . 53

Cooling Tower Air Flow Rates (ESC) . . . . . . 56

Sodium Ion Concentration and Mineral Ion

Concentration Ratios of the Pittsburg Unit 7

Cooling Tower Circulating Water . . . . . . . 58

Pittsburg Plant Cooling Tower Drift and Mineral

Mass Emission Rates (ESC). . . . . . . . . . 61

Representative Drift Mass Emission Per Cell as a

Function of Droplet Size for the Pittsburg Plant

Cooling Towers (ESC). . . . . . . . . . 63

Comparison of SP and PILLS Drift Mass Flux in the

Droplet Size Range 70-300 $\mu \mathrm{m}$ (ESC Data for Cell 1-9, 6-18-78).

Comparison of SP (ESC) and Photographic (Calfran)

Methods for Measurement of Drift Mass Flux for

Droplets Larger Than $100 \mu \mathrm{m}$ for Reference Cel 1

1-7 of the Pittsburg Plant Cooling Towers.

Hourly Average Meteorological Data for the

Pittsburg Power Plant Site During the June

METER Drift Study.

Drift Droplet Deposition Patterns for Test Run 1,

6-16-78 (See Table El.1 for Detailed

Droplet Spectra). 
15 Drift Droplet Deposition Patterns for Test Run 2, 6.17.78 (See Table ET.2 for Detatled

Droplet Spectra).......

16 Drift Droplet Deposition Patterns for Test Run 3, 6-15-78 (See Table El.3 for Detailed

Droplet Spectra). . . . . . . . . . . . 74

17 Drift Droplet Deposition Patterns for Test Run 4, 6-21-78 (See Table E1.4 for Detailed

Droplet Spectra) . . . . . . . . . . . . . 75

18 Drift Droplet Deposition Patterns for Test Run 5, 6-18-78 (See Table El.5 for Detailed Droplet Spectra). . . . . . . . . . . 76

19 Drift Droplet Deposition Patterns for Test Run 6, 6-22-78 (See Table El.6 for Detailed Droplet Spectra). . . . • . . . . . . . 77

20 Drift Droplet Deposition Patterns for Test Run $X$, 6-25-78 (See Table El.X for Detailed Droplet Spectra). . . . . . . . . . . . . 78

21 Mean Droplet Salinity Values as a Function of Downwind Distance for Each Test Run. . . . . . . 107 


\section{$\underline{\text { LIST OF FIGURES }}$}

Location of the PG\&E Pittsburg Power Plant on the South Shore of Suisun Bay in California, , . , 12

Frequencies of Winds with Speeds $\leq 5.4 \mathrm{~m} \mathrm{~s}^{-1}$ during June at Pittsburg, California as a Function of Wind Direction for Various 2-hr Time Periods . . . . 16

Frequencies of Wind with Speeds $\geq 5.4 \mathrm{~m} \mathrm{~s}^{-1}$ during June at Pittsburg, California as a Function of Wind Direction for Various 2-hr Time Periods

Cooling Tower Layout, Cell Designation and Identification of Cells Selected for Intensive Characterization. Measurement Location of Cool ing Tower Parameters are Also Shown and Identified in the Legend (ESC, PG\&E Drawing) . . . . 22

Equal Area Measurement Points for the PG\&E Pittsburg Unit \#7 Cooling Tower Fan Stack (ESC Drawing). Intensive Characterization was Carried Out at Points 1-12. ESC and Calfran Droplet Comparison Studies were Made at Points A-F . . . . . . . . . . . 24

6 Schematic of the Field Deployment of the Doppler Acoustic Wind Sensor Showing the Transmitter, 3 Receivers and 3 Spatial Cells from Which the 3-Component Winds are Computed . . . . .

Sampling Station and Plant Layout for the PG\&E

Pittsburg Power Plant Cooling Tower Drift Study . . 35

Droplet Diameter Versus Stain Diameter or Width for Droplets Settling at $0 \mathrm{~m} \mathrm{~s}^{-1}$ Simulated Horizontal Wind Speed and for Droplets Impacting on a Tilted $45^{\circ}$ Angle Surface at $7.5 \mathrm{~m} \mathrm{~s}^{-1}$. . . . 46

Droplet Diameter Versus Stain Diameter or Width for Droplets Impacting at Simulated Horizontal Wind Speeds of $0,2.5,5,7.5$ and $10 \mathrm{~m} \mathrm{~s}^{-1} . . .$. .

Updraft Air Speed and Dry-Bulb Temperature Profiles for the PG\&E Pittsburg Unit 7, Cooling Tower 7-1, Cel1 12, 6-16-78, 0730-1200 PDT (ESC). 
Sodium Ion Concentration of the Cooling Tower Circulating Water as a Function of Sample Collection Time and Day. The PG\&E Value is Calculated from a Total Salt Concentration, Assuming that $\mathrm{Na}^{+}$is $34 \%$ of the Salts in Seawater . . . . . . . . . 57

12 Representative Drift Mass Emission Spectrum Per Ce11 for the PG\&E Pittsburg Cooling Towers (ESC) . . . 65

Drift Droplet Mass Deposition Pattern for Test Run 1,6-16-78, with Both Towers Operating . . . . . 79

Drift Droplet Mass Deposition Pattern for Test Run 2,6-17-78, with Both Towers Operating . . . . 80

Drift Droplet Mass Deposition Pattern for Test Run 3,6-15-78, with Both Towers Operating . .

Drift Droplet Mass Deposition Pattern for Test Run 4, 6-21-78, with Tower 7-2 Operating Only . . . . 82

Drift Droplet Mass Deposition Pattern for Test Run 5, 6-18-78, with Tower 7-1 Operating Only . . . . 83

Drift Droplet Mass Deposition Pattern for Test Run 6,6-22-78, with Both Towers Operating . . . . . 84

Peak Drift Droplet Mass Deposition Rate as a Function of Downwind Distance for Test Runs 1-6 . . . 85

Comparison of Drift Droplet Size Spectra Obtained by Various Interrogations of SP Sample $0 A-2(T i l t)$, 6-21-78. Curves a-d are discussed in the Text. . . . 86

Empirical Constants $a$ and $b$ for the Calibration Equation $D_{d}=A D_{s}{ }^{b}$ as a Function of Wind Speed . . 89

Sampling Geometry for the Near Tower Drift Test, Test Run $x, 6-25-78$, Tower 7-1. The Dots $(\bullet)$ Show the Sampling Locations; the Numbers Identify Them.

Sodium Drift Mass Deposition Pattern for Test Run 1,6-16-78, with Both Towers Operating .

Sodium Drift Mass Deposition Pattern for Test Run 2, 6-17-78, with Tower 7-1 Operating Only . . . . 94 
Sodium Drift Mass Deposition Pattern for Test Run 4, 6-21-78, with Tower 7-2 Operating Only. . . . 96

Sodium Drift Mass Deposition Pattern for Test Run 5, 6-18-78, with Tower 7-1 Operating Only. . . . 97

Sodium Drift Mass Deposition Pattern for Test Run 6, 6-27-78, with Both Towers Operating.

Sodium Drift Deposition Rate as a Function of Downwind Distance for Test Run 1, 6-16-78, with Both Towers Operating. Experimental Values are Compared to Those Calculated by ESC for a Droplet Salinity of a) $750 \mathrm{ppm}$ and b) $250 \mathrm{ppm}$. . . . . . 99

Sodium Drift Deposition Rates as a Function of Downwind Distance for Test Runs 2, 4 and 5 for Single Tower Operation Oniy. . . . . . . . . . 100 Downwind Distance for Test Runs 3 and 6 , with Both Towers Operating. 
.

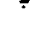




\section{INTRODUCTION}

Both the Electric Power Research Institute's (EPRI) Reject Heat Management Program and the U.S. Department of Energy's Meteorological Effects of Thermal Energy Releases (METER) Program are investigating the environmental and meteorological effects of power plant cooling systems. An important element of this research is the study of drift from cooling towers. An essential step in the prediction and mitigation of drift effects is the modeling and prediction of drift dispersion patterns and concentrations. While a number of analytical models have been formulated to do this, there are little data available to validate and improve these models.

Drift is defined as that component of the circulating water that is entrained in the cooling tower exhaust airflow as small droplets and is carried out beyond the tower where it eventually is deposited on the ground. The drift droplets are produced mechanically within the tower whereas the visible plume condensate droplets are created through cooling of the saturated tower exhaust air. The differentiation between these droplet sources is important since the drift will contain concentrations of dissolved minerals and chemicals similar, if not identical, to concentrations of the circulating water. Depending upon the chemicals present in the circulating water, drift may have an adverse effect on the environment. Consequently, in order to assess environmental impact, it is important that the amount of drift and its resulting distributions in the air and on the ground be determined.

Each cooling tower can be expected to yield a unique drift distribution, depending on the type and size of the tower and the design of the drift eliminators. Meteorological conditions also play an important role in determining drift distribution. Generally, a complex model is required to provide cooling tower drift assessment for any particular tower under the varied modes of its operation and the range of meteorological conditions to which it will be subjected. 
A number of models have been developed to estimate drift distributions. Chen (1977) and Policastro et al. (1978) have reviewed several of these models. By using a common set of input parameters based on representative values obtained from various field experiments, Chen (1977) found that among the 10 models which he considers the maximum deposition differs by two orders of magnitude with a wide range in downwind location of the peak deposition. He concluded that no particular model can claim superiority over another without verification from field data, in particular surface drift deposition measurements.

Policastro et al. (1978) compared the predictions of 10 models with field data taken during the Chalk Point dye tracer study, the most comprehensive study to date of drift from a single natural draft cooling tower (Webb, et a 1., 1977, 1978; Meyer and Stanbro, 1977, 1978). They found that three models, the ESC/Schrecker, Hosler-Pena-Pena and WigleySlawson models, compared most favorably with the deposition data and the predictions were generally within the error bounds of the data. Some discrepancies were noted, such as predictions of larger droplet diameters at deposition than were measured. In fact, they found that no model predicted each of the deposition parameters consistently within a factor of three.

At present several of the models are being fine tuned in an attempt to account more realistically for droplet breakaway and droplet evaporation (Chen and Jung, 1978; Hanna, 1978). Hanna has applied his model to data from the Chalk Point dye tracer experiment and has found that his predicted deposition rate is about a factor of three greater than the observed rate even though the predicted mass median droplet diameters are within $50 \%$ of the observed values.

The objective of the experimental work described in this report was to develop a data base that can be used for validation of drift deposition models for mechanical draft cooling towers. As in the Chalk Point study, the key experimental requirements were concurrent measurements of drift emission characteristics, ambient meteorological conditions 
and downwind drift deposition patterns. The source characteristics, including drift mass emission, drift droplet size distribution and temperature and velocity profiles, and the meteorological data, including wind speed and direction and wet- and dry-bulb temperature profiles, provide the needed input to the models. The measured deposition patterns serve as comparisons to model outputs.

The drift study was conducted at the Pacific Gas and Electric (PG\&E) oil fired Pittsburg Power Plant at Pittsburg, CA during the two week period June 12-26, 1978. The experiment was a cooperative effort involving the U.S. Department of Energy (DOE) through its METER (Meteorological Effects of Thermal Energy Releases) Program and the Electric Power Research Institute (EPRI), several contractors, including Pacific Northwest Laboratory (PNL) as the project coordinator, Environmental Systems Corporation (ESC, Knoxville, TN), Calfran Industries (Springfield, MA) and Xonics (Van Nuys, CA), and, of course PG\&E. J. H. Meyer of Johns Hopkins University, Applied Physics Laboratory (JHU-APL) served as a technical consultant to the experiment.

Source characterization measurements were performed by ESC under EPRI sponsorship. Meteorological and surface deposition measurements were carried out by PNL. In addition other limited comparison tests were conducted by Calfran and Xonics. Calfran used a photographic technique to measure source drift droplet size distributions. These measurements were to be compared to the ESC derived size distributions and drift emission rates. The Calfran tests were performed after the June test rather than concurrently with ESC's measurements. During the final days of the June test and continuing until the end of the month, Xonics provided remote measurements of vertical wind profiles with a doppler acoustic radar system to compare to the wind measurements from the PNL tethered balloon system.

Analyses of the various data were carried out by the individual contractors. Assembly of the final report, including the coordination of all data was the responsibility of PNL. In addition, ESC also carried out a 
calibration study of drift droplets impacting on water sensitive papers (SP) at oblique incidence. This study was jointly sponsored by PNL and EPRI.

This report is divided into sections describing the conclusions, background information about the Pittsburg site, experiment design and execution, data analysis and reductions, and summary of results. Included in the Appendices are detailed listings of the meteorological and deposition data. No attempt is made in this report to use these data for drift model validation, although a comparison of measured deposition rates is compared to those calculated by R. Moore of ESC using the ESC model. 


\section{CONCLUSIONS AND RECOMMENDATIONS}

A comprehensive experiment to study drift from mechanical draft cooling towers was conducted during June 1978 at the Pacific Gas and Electric Company's (PG\&E) Pittsburg Power Plant located at Pittsburg, California. The objective of the experiment was to establish a data base for use in drift deposition model validation. This objective was met by the simultaneous measurement of cooling tower source emission parameters, meteorological variables and drift deposition patterns during seven of eight test runs. In this report, the results from six of these test runs are presented and discussed.

Environmental Systems Corporation (ESC) conducted the source characterization measurements. These measurements included cooling tower emission parameters such as updraft velocity and temperature profiles, liquid and mineral mass drift emission rates, and drift droplet size distributions. ESC also provided plant and cooling tower operational parameters, obtained either from its own measurement program or from the PG\&E plant log.

Pacific Northwest Laboratory (PNL) carried out the meteorological and surface drift deposition measurements. The meteorological measurements included wet- and dry-bulb temperature and wind speed and direction on a continuous basis from sensors on a $10 \mathrm{~m}$ tower and on an intermittent basis from an instrumented tethered balloon system. The latter measurements provided information on the vertical structure of temperature, moisture and mass transport. Surface deposition measurements included both droplet and bulk mineral mass deposition rates.

Substantial variation in drift emissions were noticed. Large day-today variations for a given cell and large cell-to-cell variations were observed. Because of the large variability of drift mass emission a representative emission rate per cell was calculated by ESC using a weighted average based on both the pretest survey and the detailed characterization of seven cells. The problem of deriving a total droplet emission spectrum and rate from one or two twoers is complicated and the modeler must decide on the amount of detail he needs to satisfactorily predict downwind deposition patterns. 
Assuming that ESC's averaging procedure was reasonable, the emission rate per cell was found to be $4.8 \mathrm{~g} \mathrm{~s}^{-1}$. If all $26 \mathrm{cells}$ were operating the total emission rate would be $124 \mathrm{~g} \mathrm{~s}^{-1}$. The latter value may be uncertain by anywhere from 30 to $70 \%$, depending upon the validity of the averaging procedure. With a total circulating water flow rate of $20 \mathrm{~m}^{3} \mathrm{~s}^{-1}$, the $124 \mathrm{~g} \mathrm{~s}^{-1}$ emission rate corresponds to a drift fraction of $0.0006 \%$ compared to the guaranteed drift rate of $0.004 \%$.

Comparison of drift droplet size distributions emitted from a reference cell on Tower 7-1 by several techniques were not as satisfactory as originally planned. The sensitive paper (SP) and light scattering (PILLS) devices were compared only on one day as a result of equipment malfunction. The results indicated that the PILLS device produced drift mass emission rates which were typically 20\% lower than the SP method. On the other hand, data from the photographic device were not compared with simultaneous SP-acquired data, since these measurements were acquired nearly a month after completion of the main drift experiment. Consequently, while the photographic data show variations similar to those obtained by the SP method there was no way of proving whether the cooling towers were operating in similar modes during the two different test periods.

Meteorological conditions during the drift study were characterized by relatively high winds, warm temperatures and moderate humidities. The relatively high winds increased the uncertainty in the measured deposition patterns. In spite of the large (factor of 2 or 3 ) uncertainty in the measured deposition rates, prel iminary calculations of drift deposition rates by ESC using its own model and the source and meteorological data described above are in agreement with each other for test run 1, 6-16-78.

Mineral depositions arising mainly from blowing dust produced substantial interference with the downwind deposition patterns, especially at the greater downwind distances where drift deposition rates were small. The measured drift mineral deposition rates were uncertain by as much as a factor of two or more after this variable background component was estimated and subtracted from the total deposition rates. The effects of various 
structures, such as the electrical switchyards were apparent in data for the three days when winds were from the west or WNW.

Droplet deposition rates were also uncertain as a result of the relatively high winds, which produced droplet stains on the sensitive papers that were streaked and difficult to analyze in an automated manner. Calibration of sensitive papers for droplets incident as oblique angles was necessary to properly interpret these data.

The meteorological conditions during the test period did not provide drift data representative of all the conditions which would be encountered at the Pittsburg Plant, but they probably gave a reasonable picture of drift emissions and depositions during the dry, warm-to-hot summer conditions of the area. Winds were typically $5 \mathrm{~m} \mathrm{~s}^{-1}$ or larger from the 240300 direction. Relative humidities and dry bulb temperatures were typically 50-60\% and 15-20 C, respectively, during the experiment. Such warm temperatures, low humidities and high winds had the effect of rapidly drying out the drift droplets and dispersing them over a broad area. From a practical, experimental point of view this meant that the anticipated drift accumulation at the receptors was much smaller than what one might observe in the winter months at this site.

Comparison between several systems for the measurement of various meteorological variables, in particular the vertical profile of wind direction and speed, were carried out. In general there was favorable agreement between the in situ and remote sensing measurements.

In view of the uncertainties that arose in the interrogation of the deposition SP as a result of using an incorrect calibration equation and as a result of problems of measurement of the droplet stains with an automated scanning and reading device, certain (or a11) of the SPs could be remeasured using a more manual approach.

Although the experiment plan had the benefit of input from several other groups that have been involved in drift experiments (e.g., the Chalk Point Cooling Tower Project), several improvements to the experiment design could have been made. Larger deposition pans would have made the 
analysis of the bulk mineral deposition much easier and less uncertain. Some type of wind screen to reduce the horizontal wind component might have allowed for better control of the stain images. High-volume samplers should have been used to measure the air concentration of the dry nondepositing drift material.

While the present study did not encompass as wide a range of meteorological conditions as would be required for complete validation of various drift models, it has contributed a unique set of data for that purpose. 
BACKGROUND

\section{SITE EVALUATION AND SELECTION}

Because of potential drift interferences from other sources, e.g., drift from the stack plume at Chalk Point (Meyer and Stanbro, 1977), plans were made to give high priority to nuclear power plants with mechanical draft cooling towers, such as the Palisades plant at South Haven, MI, the Duane Arnold plant near Cedar Rapids, IA, or the Prairie Island plant near Red Wind, MN. The oil-fired PG\&E Pittsburg plant at Pittsburg, CA and the fossil fuel Jack Watson plant at Gulfport, MS, were also considered acceptable since they did not use saline or brackish waters for stack scrubbers.

Of this list of candidate sites, responsible personnel at only two plants were sufficiently familiar with the objectives of the proposed experiment to assure permission to conduct the study in the spring 1978. These two sites were the Palisades and Pittsburg plants. A site visit of the Palisades plant on 31 october 1977 was conducted. The site was found to be unacceptable because of terrain (numerous ridges of sand dunes) and ground cover (heavily forested with considerable underbrush) problems.

On 19 December 1977 a visit to the Pittsburg site was made. A maintenance outage was in effect on the unit using the two Marley cooling towers during the site visit so that actual operation of the towers could not be observed and preliminary test field samples could not be taken. In addition to examining the cooling towers, which were being plugged for leaks around the drift el iminators by PG\&E and Marley personnel, potential ground-level sampling station locations were investigated, including those used by ESC during a cooling tower performance test conducted for PG\&E in November 1977.

The site appeared to be suitable for the kind of drift study required for validation of drift models. Advantages of the site were: 
- Drift data, already acquired at the site, could be used with PG\&E's approval in program planning.

- The cooling towers employed salt water. Sodium had been used with good success for mineral measurements in previous drift programs.

- The site was flat with a number of potential ground-level measurement station locations; site plans and an aerial photograph of the site were to be provided by PG\&E.

- Winds were said to be fairly constant from the west, which were verified subsequently on closer examination of the wind rose data supplied by PG\&E from the on-site meteorology station.

- Liaison with PG\&E and the plant had been established, and PG\&E personnel had experience with drift measurement programs.

- The plant is currently undergoing maintenance so that the possibility of outage during anticipated spring measurements was expected to be small.

Disadvantages of the site were:

- The switchyards may sweep out droplets from the cooling towers under high wind conditions altering the droplet component downwind. In general, westerly winds will carry the drift over areas that have switchyards, oil storage tanks and other buildings that can influence downwind drift data.

- Under dry conditions, the area upwind of the switchyards is sprayed with salt water to prevent dust formation. This spraying must be coordinated with the measurements.

- Wind conditions, though steady from the west, may be too high to interpret deposition results reliably.

- The plant boundaries extend only $1 \mathrm{~km}$ from the cooling towers such that placement of stations beyond this point in residential areas could have required close supervision.

- The subject of emissions from the plant (including the cooling towers) were a sensitive one to PG\&E since the plant falls within the jurisdiction of the Bay Area Air Pollution Control District. 
On the basis of this site visit it was decided that the advantages outweighed the disadvantages and that the site was acceptable for the test.

Several other Pittsburg site visits were conducted after the maintenance outage was completed to examine the site in some detail for the location of the ground-based sampling stations, a 10-m meteorological tower and sites for operation of a tethered-balloon system. The most critical evaluations made were for the sampling station location to be free from interference from various structures, such as transmission lines and towers, electrical switchyards, fences and buildings. Several serious questions were raised concerning these possible interferences by J. H. Meyer (JHU/APL) who took part in one of the site visits. A subsequent survey indicated that only 4-5 of a tatal of 25-35 stations would be seriously shadowed by various structures. The decision was made to continue with the Pittsburg Power Plant as the prime study site.

\section{PG\&E PITTSBURG POWER PLANT DESCRIPTION}

The site is located on the shore of Suisun Bay near the confluence of the Sacramento and San Joaquin Rivers (Fig. 1). The plant consists of seven oil-fired units. Units 1-6 employ once-through cooling, while Unit 7 (rated at 720 MWe net) is cooled by two 13-cell Marley rectangular mechanical draft cooling towers located, approximately $0.5 \mathrm{~km}$ from the unit, on the center berm in a cooling canal west of the plant. The two cooling tower units are identified as Tower 7-1 and Tower 7-2; Tower 7-2 is about $325 \mathrm{~m}$ west of Tower 7-1 measured from center to center (each tower is about $143 \mathrm{~m}$ in length). Individual cells are numbered 1-13 from west to east, Cell exit diameter is $10 \mathrm{~m}$ with the exit plane $5.5 \mathrm{~m}$ above the fan deck and $18 \mathrm{~m}$ above ground level. The canal was previously used as a spray canal for Unit 7.

Towers $7-1$ and $7-2$ are unique in the sense that no direct connection exists between the condenser cooling water flow and the tower water flow. Cooling water for the Unit 7 condenser is withdrawn from one end (cold) of the canal and discharged to the other (hot). The two cooling towers 


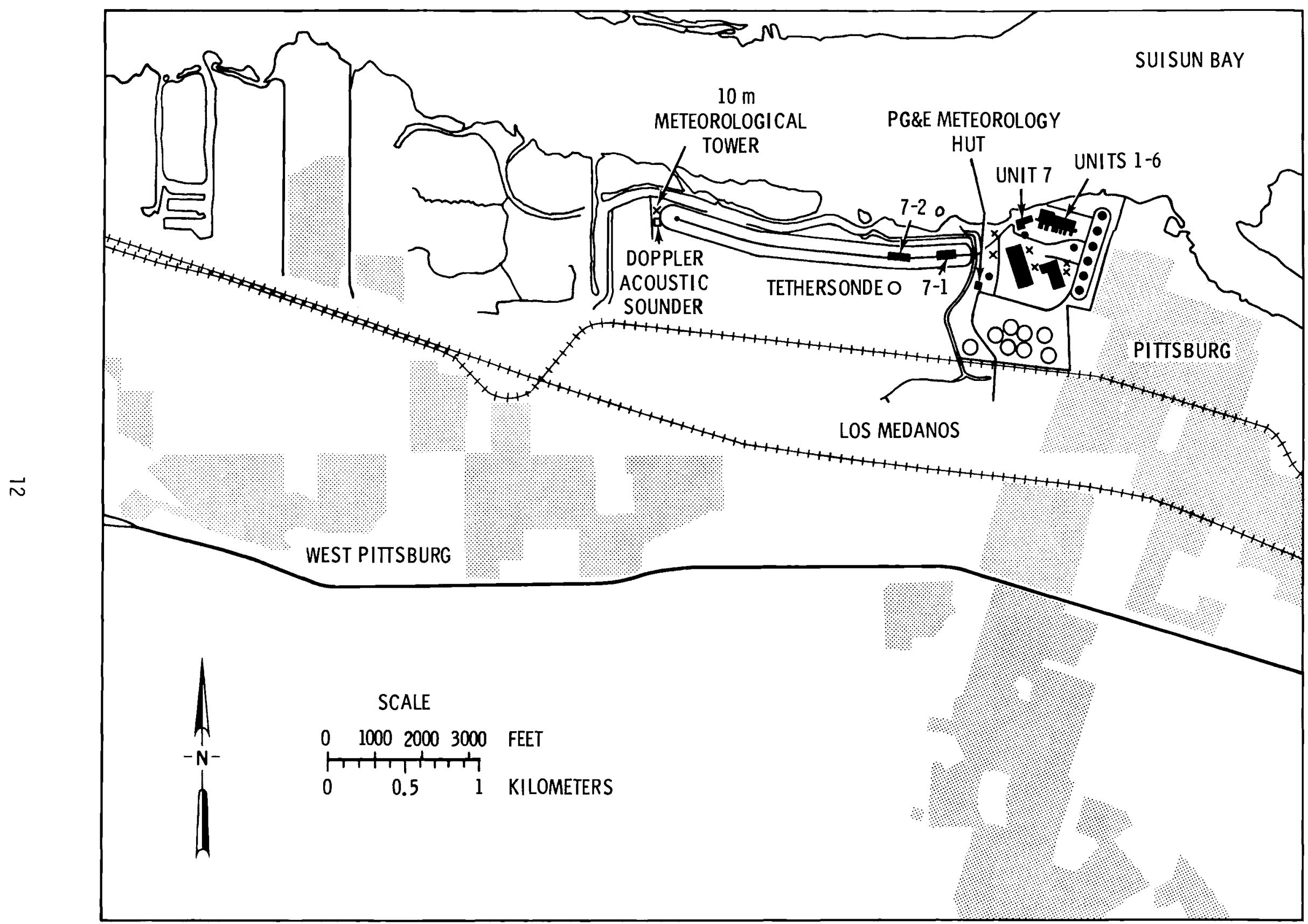

FIGURE 1. Location of the PG\&E Pittsburg Power Plant on the South Shore of Suisan Bay in California 
withdraw water from the hot leg and discharge it to the cold leg. The possibility existed that inlet water temperatures might be slightly different since the withdrawal points were not exactly the same in the hot leg. This difference, however, turned out to be small $\left(<1.1^{\circ} \mathrm{C}\right.$ on the average). Since plume buoyancy is determined primarily by exit air conditions, which were monitored continuously during the source measurements, it should be possible to establish the relationship between net generation and tower load from these and other operational parameters to satisfy the requirements of model inputs.

The towers were stated to have a guaranteed drift rate of $0.004 \%$ and a nominal circulating water flow of $23.5 \mathrm{~m}^{3} \mathrm{~s}^{-1}$. Because leaks were sealed around the cooling tower drift el iminators during the December 1977 maintenance outage, tower performance should have been near to the manufacturers specifications. Other factors related to cooling tower were blowdown and makeup rates. Makeup water was added to the cooling system at a constant rate throughout the day near the cold end of the canal. The canal water level was regulated by the blowdown rate.

Total dissolved solids concentration of the canal water has been found to vary over several orders of magnitude, with sodium ion concentrations varying between 0.01 and $1.5 \%$ by weight.

\section{PRELIMINARY TESTS}

Several tests were conducted at the site and in the laboratory to evaluate sampling methodology and to define measurement strategies. These included:

- pretest observations of drift eliminator condition;

- evaluation of drift emission characteristics of all operating cells using sensitive papers;

- evaluation of wind rose climatology for June from PG\&E wind data over the seven year period, December 1970 - November 1977; 
- basin/canal water dissolved solids;

- evaluation of deposition pans for background interference, recovery efficiency and recovery sensitivity.

ESC conducted the first two of the above tests while PNL carried out the rest.

The purpose of the source pretests was to devise a sampling strategy that would yield representative drift emission characteristics for both towers. It was clearly impractical to measure all twenty-six cells of Towers 7-1 and 7-2 simultaneously. Even if it were available most models could not accept such detailed information. However, knowledge of the magnitude of cell-to-cell variations, systematic variations with cell location and variations within a particular cell would be necessary to specify the range of variation of source parameters.

Practical considerations of instrument sample time and cell exit plane access dictated that comprehensive drift emissions measurements be limited to one cell characterization per day of testing for a minimum of six cells. Selection of individual cells for intensive measurement was on the basis of the pretest visual examination of drift el iminator condition, of droplet discharge in the plenum through leaks, and of drift at the fan stack exit plane and by exposure of sensitive papers for relative ranking of cell emissions.

Although leaks had been caulked during the maintenance outage, there still existed in the majority of the cells water droplet streams from the fill area that splashed on structural members in the plenum generating droplets small enough to be entrained in the updraft air flow. Because of the irregular spatial and temporal nature of their generation and the fact that they did not pass through the drift el iminators, these droplets could be expected to modify the emitted drift droplet size distribution. This point will be addressed in more detail in the discussion of results. 
Ranking of cell emissions was divided into categories of high, medium and low drift emissions. It was found from examination of the sensitive papers (SPs) that all cells of Tower 7-1 were ranked medium, except for cell 3, which was high and cells 8 and 9, which were low; for Tower 7-2 4 cells were high (\# 4,9,11,12), 6 cells were medium (\# 1,2,3,6, $7,8)$ and 3 cells were not operating (\#5,10,13).

The decision was made to devote full characterization of 4 cells on Tower 7-1 (\#3,7,9,12--one high, 2 medium and 1 low), and of 2 or 3 cells on Tower 7-2 (\#3,7,12--one high and one or two medium). Furthermore, the middle cells of each tower (\#7) were designated reference cells where 1 imited SP exposures would be made daily (provided the tower was operating) as an indication of daily cell droplet emission variation. Details of the pretest source measurements are contained elsewhere (Webb, 1979).

Layout of ground-level stations for the measurement of drift deposition required the evaluation of the expected wind rose at the PG\&E Pittsburg Plant during June. PG\&E provided summaries of wind measurements over a seven-year period from 1971-1977 for the month of June and for different times of the day. Frequencies of winds with speeds $\leq 5.4 \mathrm{~m} \mathrm{~s}^{-1}$ and $\geq 5.4 \mathrm{~m} \mathrm{~s}^{-1}$ as a function of direction and time of day are shown in Figs. 2 and 3 , respectively. These figures show that winds are persistently from the west with wind speeds exceeding $5.4 \mathrm{~m} \mathrm{~s}^{-1}$ more frequently than below $5.4 \mathrm{~m} \mathrm{~s}^{-1}$ for all hours of the day except early morning hours. Consequently early morning starts for the tests were desirable.

During the later site visits, several deposition pans were exposed for a short time near one of the operating towers to test handling and recovery procedures as well as examine recovery sensitivity. Unexposed and exposed deposition pans were rinsed and the resulting samples were analyzed for various negative ion concentrations, including $\mathrm{Cl}^{-}$and $\mathrm{SO}_{4}{ }^{--}$. It was found that ion interference from unexposed pans (either prerinsed or unrinsed) was small and that an 8-min sample showed sufficient deposition 


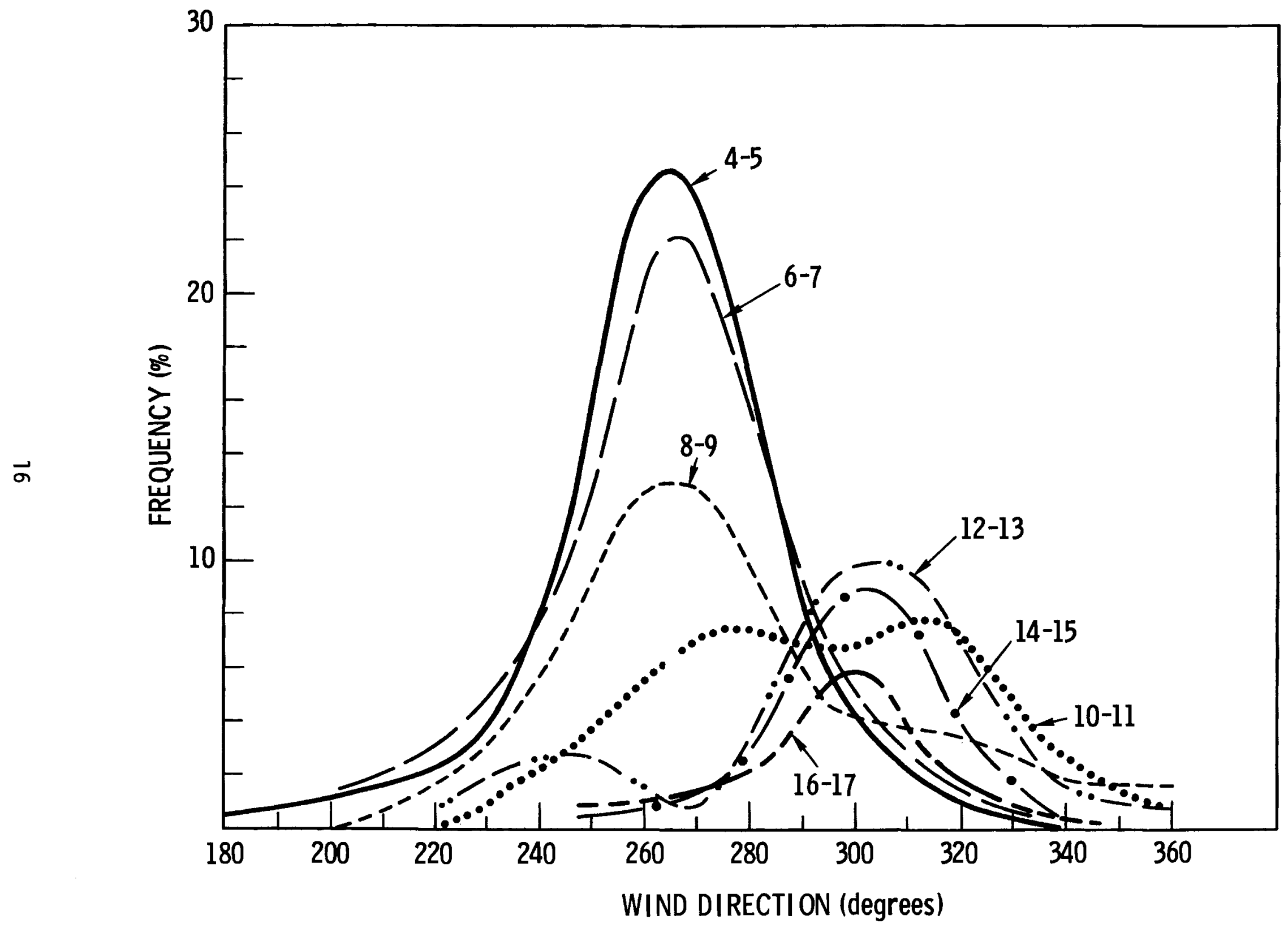

FIGURE 2. Frequencies of Winds with Speeds $\leq 5.4 \mathrm{~m} \mathrm{~s}^{-1}$ during June at Pittsburg, California as a Function of Wind Direction for Various 2-hr Time Periods 


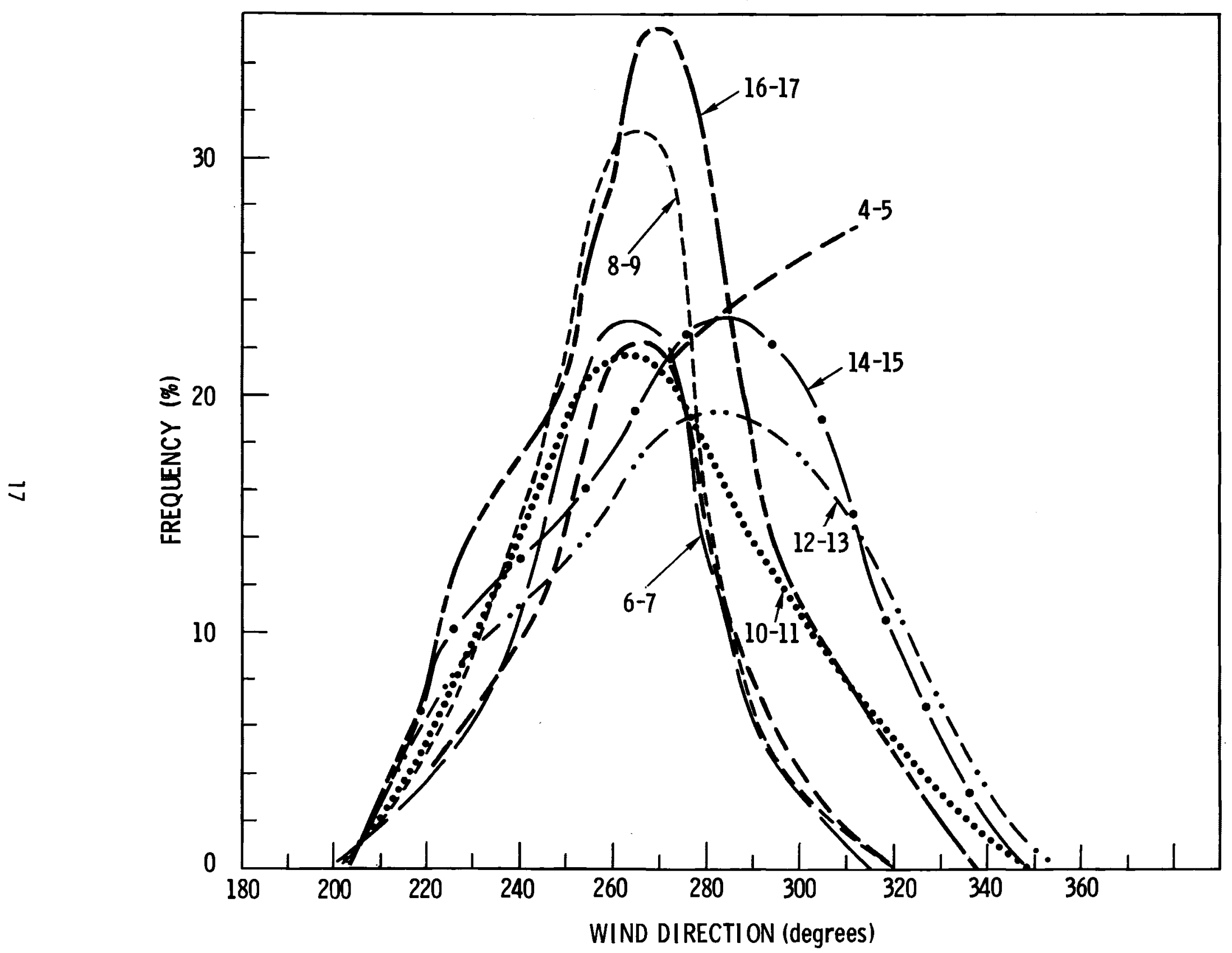

FIGURE 3. Frequencies of Winds with Speeds $\geq 5.4 \mathrm{~m} \mathrm{~s}^{-1}$ during June at Pittsburg, Cal ifornia as a Function of Wind Direction for Various 2-hr Time Periods 
material to be within the sensitivity range of the analyzer instruments (a discussion of the analyzers and recovery procedure follows in a later section). In addition, a known quantity of $\mathrm{NaCl}$ was deposited in an unexposed pan to test recovery efficiency. The results of this test showed that nearly all of the sample was recovered from the pan.

In summary the results of the various pretests gave reasonable assurance that sampling procedures and methodology to be employed in the comprehensive tests would result in successful recovery of information required for establishing a data base for drift from mechanical draft cooling towers. 


\section{EXPERIMENTAL}

Eight test runs were conducted during the June $1978 \mathrm{drift}$ study at the Pittsburg Power Plant. Downwind deposition measurements were coordinated with ESC's source measurements on the first seven tests. The eighth test was conducted with no concurrent source measurements. In addition, limited droplet measurements were made on the fan deck of a single tower to examine near-field deposition during a ninth and final test. The tests were divided into two-tower operation (three tests), Tower 7-2 alone (two tests), and Tower 7-1 alone (three tests).

Meteorological conditions were much windier than the previous June cl imatology indicated. The winds, though persistently from SW to $W$ to NW, were more intense during the morning hours than usual. Only two test runs were made where the wind speed could be classified as $5 \mathrm{~m} \mathrm{~s}^{-1}$ or less. The other tests were carried out under conditions where wind speeds ranged from 5 to $10 \mathrm{~m} \mathrm{~s}^{-1}$. A summary of the test runs and average meteorological conditions is found in Table 1.

TABLE 1. Summary of Test Runs and Average Meteorological Conditions During the June 1978 Pittsburg Drift Study

\begin{tabular}{|c|c|c|c|c|c|c|}
\hline Date & $\begin{array}{l}\text { Run } \\
\text { No. }\end{array}$ & $\begin{array}{c}\text { Temperature } \\
\left({ }^{\circ} \mathrm{C}\right)\end{array}$ & $\begin{array}{c}\text { Relative } \\
\text { Humidity } \\
(\%) \\
\end{array}$ & $\begin{array}{l}\text { Wind } \\
\text { Speed } \\
\left(\mathrm{ms}^{-1}\right) \\
\end{array}$ & $\begin{array}{c}\text { Wind } \\
\text { Direction } \\
\left({ }^{\circ}\right)\end{array}$ & Comment \\
\hline $6-15$ & 3 & 23.6 & 43 & 6.6 & 292 & Both towers \\
\hline $6-16$ & 1 & 18.4 & 55 & 4.8 & 269 & Both towers \\
\hline $6-17$ & 2 & 19.7 & 57 & 3.9 & 265 & Tower 7-1 only \\
\hline $6-18$ & 5 & 16.9 & 63 & 7.1 & 241 & Tower 7-1 only \\
\hline $6-20$ & 8 & 13.5 & 85 & 7.6 & 242 & Tower 7-2 on ly \\
\hline $6-21$ & 4 & 18.3 & 65 & 5.7 & 246 & Tower 7-2 on $1 y$ \\
\hline $6-22$ & 6 & 16.8 & 66 & 6.4 & 248 & Both towers \\
\hline $6-24$ & 7 & 16.7 & 61 & 7.7 & 248 & Tower 7-1 only \\
\hline $6-25$ & $x$ & 15.9 & 65 & 5.4 & 268 & Tower $7-1$ only \\
\hline
\end{tabular}


In the following sections a description of the field experiment setup and test procedure and analysis procedures for the source characterization, meteorological, deposition, and other relevant measurements are given. Since a complete summary of the source measurements is contained in ESC's Final Report (Webb, 1979) only a condensed summary of these measurements with illustrative tables and figures is given here.

\section{SOURCE CHARACTERIZATION}

Because of the unique linkage between condenser cooling and the operation of the cooling towers, it was necessary to have a complete description of both plant and cooling tower systems. Such a description included:

- unit 7 generating load,

- L'nit 7 condenser water flow rate,

- unit 7 condenser inlet and outlet water temperature,

- canal inlet and outlet temperature,

- cooling Tower 7-1 water flow rate,

- cooling Tower 7-1 inlet and discharge water temperature,

- cooling Tower 7-2 water flow rate,

- cooling Tower 7-2 inlet and discharge water temperature,

- cooling Tower 7-1 total fan power (airflow),

- cooling Tower 7-2 total fan power (airflow),

- flow rate, inlet/outlet water temperatures, and fan power for individual cell being monitored.

Plant and tower operational data were acquired from the PG\&E plant log and data acquisition system or from instrumentation set up by ESC. Operational parameters available from PG\&E sources included: 
- instantaneous net-power generation at half hour intervals recorded on the half-hour and hour,

- condenser inlet and outlet circulating water temperatures (sensors and sensor accuracies not specified),

- cooling tower cold water temperatures,

- fan power from power meters located in each cooling tower control center (read and estimated by ESC).

Operational parameters acquired by ESC included:

- ambient wet- and dry-bulb temperatures,

- canal inlet and outlet temperatures,

- cooling tower hot and cold water temperatures,

- cooling tower water flow rate.

A11 ESC-acquired temperature measurements were obtained with platinum resistance temperature devices (RTD's) multiplexed to a data acquisition system. Data were acquired concurrently with cooling tower drift source and ground-level measurements.

Cooling tower water flow rate measurements were conducted only once for each tower and compared to values obtained by PG\&E personnel. Since these measurements were within $5 \%$ of the PG\&E values, more frequent checks were deemed unnecessary. Fan horsepower estimates were also compared to more accurate PG\&E determinations.

Sensor deployment and other determinations of cooling tower operational parameters are shown schematically in Fig. 4.

Source characteristics included measurements of those variables required to describe the air/vapor and drift emissions from the fan stack. These variables included:

- updraft air velocity profiles,

- air dry- and wet-bulb temperature profiles,

- drift (water) flux profiles, 

$\Theta^{\mathrm{T}}$ COLD
$\oplus \mathrm{T}_{\mathrm{HOT}}$
(W) TEET BULB
(D) TDRY BULB
- HORSEPOWER MEASUREMENTS
$\Delta$ WATER FLOW MEASUREMENTS
(1) CELL NOT OPERATING
$\otimes$ INTENSIVE CHARACTERIZATION

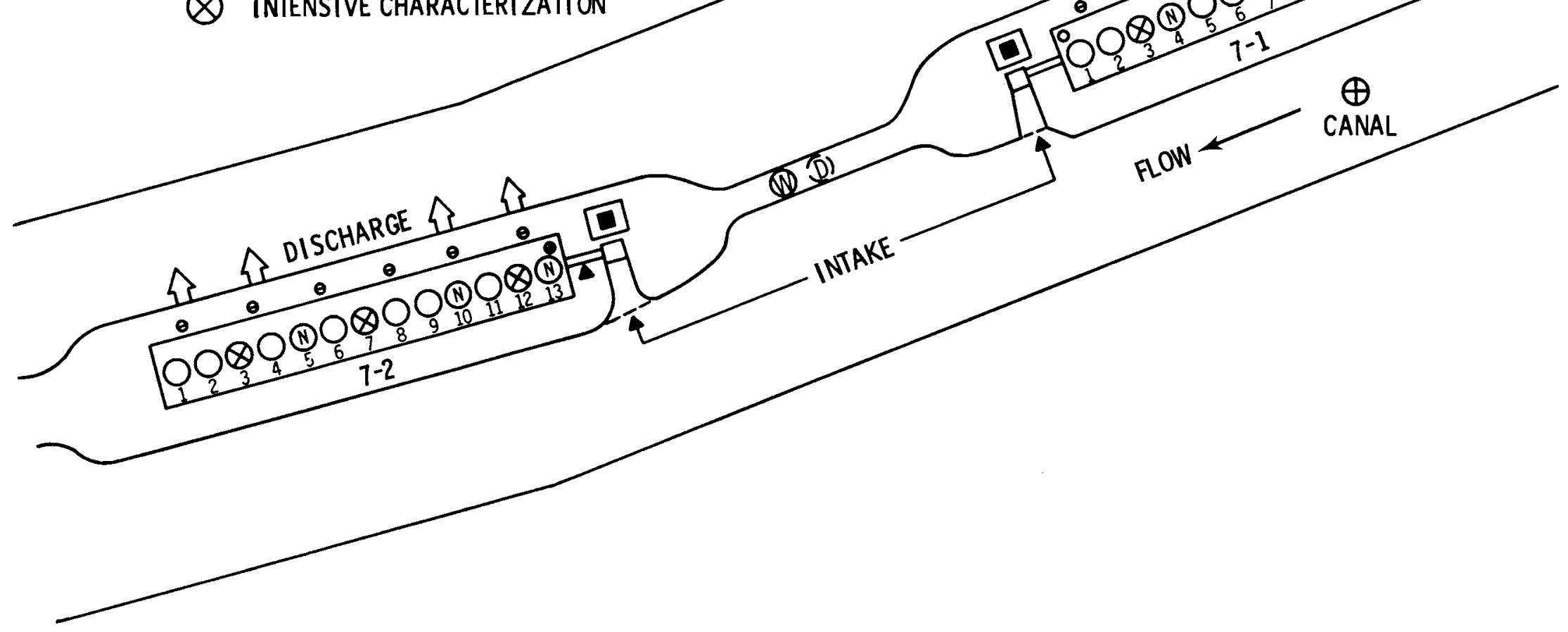

FIGURE 4. Cooling Tower Layout, Cell Designation and Identification of Cells Selected for Intensive Characterization. Measurement Location of Cooling Tower

Parameters are Also Shown and Identified in the Legend (ESC, PG\&E Drawing) 
- mineral mass-flux profiles,

- drift droplet size distribution,

- droplet salinity vs. droplet diameter.

Drift emission measurements were made near the exit plane of selected cell fan stacks on both cooling towers while cooling tower and plant operational data were also acquired. Cells were selected for intensive measurement in accordance with the measurement strategy developed in the pretest plan described earlier (see Fig. 4). For characterization of cooling tower source emissions, measurements of droplet size, mineral mass flux, updraft air velocity and updraft air temperature were performed by ESC using the following instrumentation:

- Sensitive Paper System (SP),

- Particulate Instrumentation by Laser Light Scattering System (PILLS II),

- heated Glass Bead Isokinetic Sampling System (IK),

- Gill propeller anemometer,

- electronic psychrometer.

A sample of the circulating water was also acquired from the hot water basin of the cell under measurement for later chemical analysis of the mineral tracers, sodium and magnesium. Limited sensitive paper exposures were taken daily on designated reference cells as an indication of daily cell droplet emission variation.

In order to measure the drift emission of one cell, traverses were made across two orthogonal diameters of the exit plane of the cell fan stack. The exit plane is divided into annular regions whose areas are equal; the instrument package is located at a measurement point in each area. A diagram of one of the Pittsburg fan stack exit planes with the measurement points shown is given in Figure 5 . For the Pittsburg measurements, each cell was divided into three annular areas each with four measurement points each as shown in the figure (Positions 1-12). Updraft 


\section{NORTHERN SIDE OF TOWER}

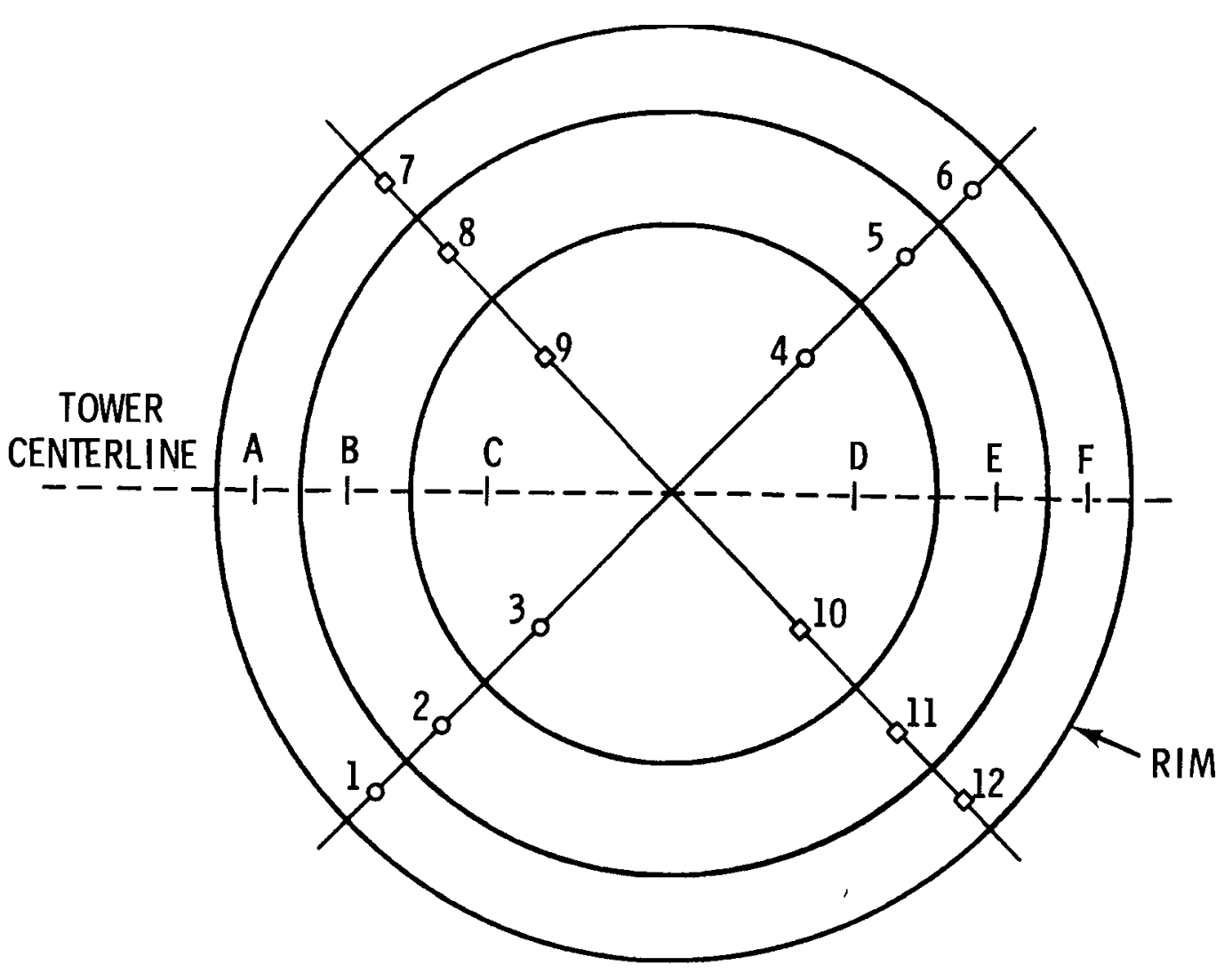

\begin{tabular}{cc}
$\begin{array}{c}\text { DRIFT } \\
\text { MEASUREMENT } \\
\text { POINT }\end{array}$ & $\begin{array}{c}\text { DISTANCE } \\
\text { FROM RIM (m) }\end{array}$ \\
\hline 1 & 0.44 \\
2 & 1.45 \\
3 & 2.95 \\
4 & 2.95 \\
5 & 1.45 \\
6 & 0.44 \\
\hline 7 & 0.44 \\
8 & 1.45 \\
9 & 2.95 \\
10 & 2.95 \\
11 & 1.45 \\
12 & 0.44 \\
\hline
\end{tabular}

DIAMETER $=9.96$ meters

FIGURE 5. Equal Area Measurement Points for a PG\&E Pittsburg Unit \#7 Cooling Tower Fan Stack (ESC Drawing). Intensive Characterization was Carried Out at Points 1-12. ESC and Calfran Droplet Comparison Studies were Made at Points A-F 
air speed and temperature were also acquired at the center of the exit plane.

A summary of the pretest and comprehensive measurements is shown in Table 2 with pertinent comments. Cell characterization indicates measurements at 12 equal area points on cross diameters in the cell exit plane with SP, IK, anemometer, and $T_{\text {wet }} / T_{\text {dry }}$. The cells characterized are also marked with an $X$ indicating the cross diameters in Figure 4 . Although the PILLS instrument was available for use from June 15 through 18, equipment malfunction prevented its use until the 18th. On June 19, no source measurements were conducted while the equipment and scaffolding were moved from Tower 7-1 to 7-2.

It was intended that several different methods for measuring the emitted drift droplet size distribution be carried out simultaneously. ESC was to provide data with their SP and PILLS systems, as already indicated, while Calfran Industries was to demonstrate a photographic technique. Because of equipment and other problems, Calfran was unable to set up its instrumentation in time for coordinated measurements with ESC. Calfran eventually completed these measurements on the reference cell (\#7) of Tower 7-1 toward the end of July.

In principle, the results of the photographic technique and the PILLS system are directly comparable since they both provide a measure of droplet size and number density in the cooling towers. However, since the PILLS system was only used during a limited test period, the more meaningful comparisons would be with the SP exposures. Since the SPs measure a droplet flux, intercomparisons of the PILLS, photographic and SP techniques can be made only by converting the measured droplet densities to droplet fluxes by means of the average updraft velocity at each measurement point and the size dependent settling velocity of each droplet size category. A more complete discussion of these points may be found elsewhere (Webb, 1979; Schrecker, et a1., 1975). 
TABLE 2. Summary of ESC Data Acquisition for the June 1978 Pittsburg Drift Study

\begin{tabular}{|c|c|c|c|c|c|c|c|c|c|c|c|}
\hline $\begin{array}{l}\text { June } \\
\text { Date }\end{array}$ & $\begin{array}{c}\text { Time of } \\
\text { Runs (PDT) } \\
\end{array}$ & $\begin{array}{r}\text { Num } \\
C \\
\text { Ope } \\
\bar{T} \\
7-1\end{array}$ & $\begin{array}{l}\text { er of } \\
11 \mathrm{~s} \\
\text { ting } \\
\begin{array}{l}\text { ver } \\
7-2\end{array} \\
\end{array}$ & $\begin{array}{l}\text { Cell \# } \\
\text { Charac- } \\
\text { terized }\end{array}$ & $\underline{S P}$ & $\underline{I K}$ & PILLS & $\begin{array}{l}\text { Opera- } \\
\text { tional } \\
\text { Param. } \\
\text { Acqu. } \\
\end{array}$ & $\begin{array}{r}\operatorname{Re} \\
\text { Spo } \\
1-7 \\
\end{array}$ & $\begin{array}{l}\text { ecked } \\
\underline{2-7} \\
\end{array}$ & Comments \\
\hline 13 & -- & 13 & $10^{\mathrm{a}}$ & & $x$ & & & & $x$ & $x$ & Pretest \\
\hline 14 & -- & 13 & 10 & & $x$ & & & & & & Pretest \\
\hline 15 & $12: 31-17: 02$ & 12 & 10 & $1-7$ & $x$ & $x$ & & $x$ & & $x$ & \\
\hline 16 & $7: 30-12: 00$ & 12 & 10 & $1-12$ & $x$ & $x$ & & $x$ & $x$ & $x$ & $\begin{array}{l}\text { Anemometer } \\
\text { Malfunction }\end{array}$ \\
\hline 17 & $7: 50-12: 15$ & 12 & $0^{b}$ & $1-3$ & $x$ & $x$ & & $x$ & $x$ & & \\
\hline 18 & $7: 33-13: 02$ & 12 & 0 & $1-9$ & $x$ & $x$ & $x$ & $x$ & $x$ & & \\
\hline 19 & -- & -- & -- & -- & -- & -- & -- & -- & -- & -- & $\begin{array}{l}\text { Moved Equipment } \\
\text { from } 7-1 \text { to } 7-2\end{array}$ \\
\hline 20 & $8: 51-13: 22$ & 0 & 10 & $2-7$ & $x$ & $x$ & & $x$ & & & \\
\hline 21 & $8: 35-12: 56$ & 0 & 10 & $2-12$ & $x$ & $x$ & & $x$ & & $x$ & \\
\hline 22 & $8: 00-12: 27$ & 12 & 10 & $2-3$ & $x$ & $x$ & & $x$ & $x$ & $x$ & $\begin{array}{l}\text { Tower } 1 \text { Reference } \\
\text { Data Acquired } \\
6-23-78\end{array}$ \\
\hline
\end{tabular}

\footnotetext{
${ }^{a}$ Three of the 13 cells with water flow but no fan operation.

$b_{0}$ indicates no water pump or fan operation.
} 
The Sensitive Paper methodology requires further elaboration since ESC's sampling procedures were modified to improve counting reliability and counting statistics, particularly for the larger droplet sizes. Two SP sizes were employed in the Pittsburg measurements (with their respective holder/mechanical shutter mechanisms). A small-area SP (47 mm in diameter) was employed for good collection efficiency of small droplets and was interrogated for droplets in the size range of approximately 10 to $100 \mu \mathrm{m}$ in diameter. A large-area SP (142 $\mathrm{mm}$ in diameter) was employed for better sample statistics in the larger size ranges $(>100 \mu \mathrm{m})$ that typically occur less frequently than the small droplets in a cooling tower.

The processing of these exposed sensitive papers, which are chemically treated so that a droplet impinging on them will generate well-defined dark blue stains on the pale yellow background of the papers, consisted of measuring the stain diameters by means of a microscope and a semi-automated 1ight-pen counter 1 inked to a minicomputer. The counts of a 11 measured stains were grouped by stain size ranges. Since the number of stains per stain size range usually decreased with increasing stain size, three

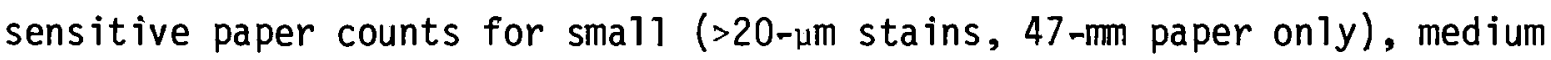
(200 to 1500-um diameter stains, 142-mm paper only) and large stains (>1000- $\mu \mathrm{m}$ diameters, 142-mm paper on1y) were typically made. The paper was divided into frames approximately $3 \mathrm{~mm}$ on a side for facilitating the counting procedure. The stain diameters given here should not be confused with drift droplet diameters which must be inferred from calibration data. The accuracy of the droplet diameter sizing of the SP methodology has been determined to be within $\pm 15 \%$ of the true droplet diameter.

Once the stain sizes are counted and grouped according to size, calibration curves for specific droplet sizes and impaction velocities were employed via computer programs to generate the original droplet sizes from which the stains were formed. In addition, an experimentally determined correction factor was applied to the data for droplet diameters below 50 $\mu \mathrm{m}$ to account for the reduction in collection efficiency with decreasing droplet diameter for the specific size of the SP disc collector and impaction velocity. 
Mineral mass flux emission rates were determined by heated glass bead isokinetic (IK) sampling tubes. The air velocity through the tube was adjusted so that it was equal to the time-mean velocity of the updraft air as determined by measurements with the propeller anemometer. The minerals collected in the IK tubes were stripped from the tubes with a wash solution which was then analyzed by atomic absorption or flame emission spectrophotometry. In this test, the wash solutions were analyzed for sodium and magnesium. The accuracy of the IK System has been determined to be within $\pm 15 \%$ of the stated mineral mass fluxes for trace elements characteristically used in these evaluations (e.g., $\mathrm{Na}, \mathrm{Mg}$, etc.). In these instances, the chemical assays are considered straightforward and routine.

The mean drift droplet salinity may be estimated by computing the ratio of total mineral mass emission rate to total drift water mass emission rate. The resultant number may also be compared to the mean basin water salinity to estimate the amount of evaporation of the drift droplets that must have occurred in the fill and/or plenum sections of the cooling tower. It would have been desirable to have determined drift droplet salinity as a function of droplet size by some independent technique in order to identify physical processes occurring within the cooling tower that may alter droplet mineral concentrations. No technique, however, was readily available at the time of this study.

The remaining instrumentation used in the tower source measurements were the Gill propeller anemometer for updraft to air speed and an ESCdeveloped electronic psychrometer for updraft air wet-bulb and dry-bulb temperatures. The anemometer was mounted in a manner that gave the vertical component of the updraft air velocity.

For characterization of the drift emission of a cell, moveable scaffolding was erected on the fan deck to support a beam which would be positioned over the exit plane of the fan stacks. The instrumentation was mounted on a carriage which could be moved back and forth along the traverse-beam once it was in position above one of the stacks. The instruments were linked via an umbilical cable to the control equipment which was situated in an enclosure on the fan deck. 


\section{METEOROLOGY}

Meteorological parameters were measured in the boundary layer by a variety of instruments, including:

- instrumented 10-m tower,

- tethered-balloon system,

- monostatic acoustic sounder system,

- doppler acoustic wind system,

- a11-sky camera,

- time-1apse camera systems.

Data collected on the $10 \mathrm{~m}$ tower included:

- dry-bulb temperature,

- wet-bulb temperature,

- three-component $u, v$, and $w$ winds.

Temperatures were measured with precision matched thermistors. Winds were measured with a three-component Gill anemometer. Data from these sensors were interrogated and stored by the data acquisition system every $2 \mathrm{~s}$. Subsequently, 1-min averages were computed and recorded onto a seven track magnetic tape. The system was in continuous operation over the entire experimental period (June 16-25), except for occasional system checks.

A portable tethered balloon system (Tethersonde: Ambient Analysis, Inc.) provided vertical profiles of temperature, moisture and horizontal wind speed and direction within the vicinity of the cooling towers as well as upwind of the towers. Profiling was performed from the surface up to as high as $400 \mathrm{~m}$ on one occasion. However, the bulk of the profiles extended up to only $100 \mathrm{~m}$. During the experimental period, the tetheredballoon system was flown on only 7 days (June 15, 16, 17, 21, 23, 24 and 25). Its operation was 1 imited to wind speeds $\stackrel{2}{<} 10 \mathrm{~m} \mathrm{~s}^{-1}$. The system was interfaced with a desk-top calculator (HP-97) and provided the following printed outputs on paper tape at approximately 30 -s intervals: 
- time,

- pressure,

- height,

- temperature,

- relative humidity,

- mixing ratio,

- wind speed and direction,

- potential temperature.

The tethered-balloon system wind speed was measured by a three-cup anemometer driving a miniature tachometer/generator. The output voltage was a linear function of RPM, which in turn was linear with wind speed, with a stated accuracy of $\pm 0.25 \mathrm{~m} \mathrm{~s}^{-1}$ over 0.5 to $20 \mathrm{~m} \mathrm{~s}^{-1}$. The wind direction sensor was a magnetically actuated circular potentiometer. The direction measurement relied on the balloon as an effective wind vane to orient the instrument package into the prevailing wind with a stated accuracy of \pm 2 degrees. The pressure change was detected by a temperature compensated aneroid, piezoresistive strain gauge element. Height was determined from the indicated pressure change. The data were telemetered to the ground receiver and converted to engineering units. (See Morris, et al., 1975 for a comprehensive review of the balloon system).

During the last 3 days of the experiment a Doppler acoustic wind system (Xondar 600, Xonics, Inc.) was employed to determine the wind profile in the boundary layer. Measurements of the horizontal wind speed and direction by the Doppler acoustic system were compared with those determined from the tethered-balloon system. Fixed level (time series analysis) as well as profiling modes provided the basis for the comparison. In addition, vertical velocity data from the acoustic sensor were matched against those obtained from the Gill anemometer on the 10-m meteorological 
tower. The Doppler acoustic system, balloon system and tower were operated approximately $1.5 \mathrm{~km}$ upwind of the cooling towers during this study.

A schematic of the Doppler acoustic wind system field setup is shown in Fig. 6. The system contains two receiver antennas which were placed to form a right angle, with the transmitter antenna at the apex. This general configuration enables determination of the horizontal wind field. With the addition of a third receiver, collocated with the transmitter antenna, the vertical component of the wind is attainable. The distance by which the receivers were displaced from the transmitter was approximately the same as the maximum altitude $(400 \mathrm{~m})$ at which the wind was to be sampled. A lower altitude limit $(150 \mathrm{~m})$ was chosen so that the elevation angle from the receiver to the scattering region at maximum altitude was not to exceed $50^{\circ}$.

The transmitter generates radiated pulses every $5 \mathrm{~s}$ in a pencil beam vertically upward, with a pulse of energy occupying at any instant only a spatial cell at some determinable altitude. Similarly, the receiver antenna forms a fan beam, narrow in azimuth to match the width of the transmitter beam it intercepts and broad in elevation to cover the desired range of altitudes. The scattered pulse arrives at the receiver after the time interval required to traverse the distance up to the altitude in question and thence to the receiver. Differentiation between signals from various altitudes can be determined by their time of arrival at the receiver; that is, signals from the lowest altitudes arrive before those from the higher altitudes. In a11, the velocity components from six altitudes were attainable at 50-m intervals.

The portion of the received signal that is associated with each altitude is transformed so that its frequency spectrum, with regard to the Doppler shift, can be examined. In order to produce a confident estimate of the received signal, an integration of a number of spectra is performed. This final averaging period is 2 min during which time 20-30 signals are processed. Following this processing, real-time display of the wind field 


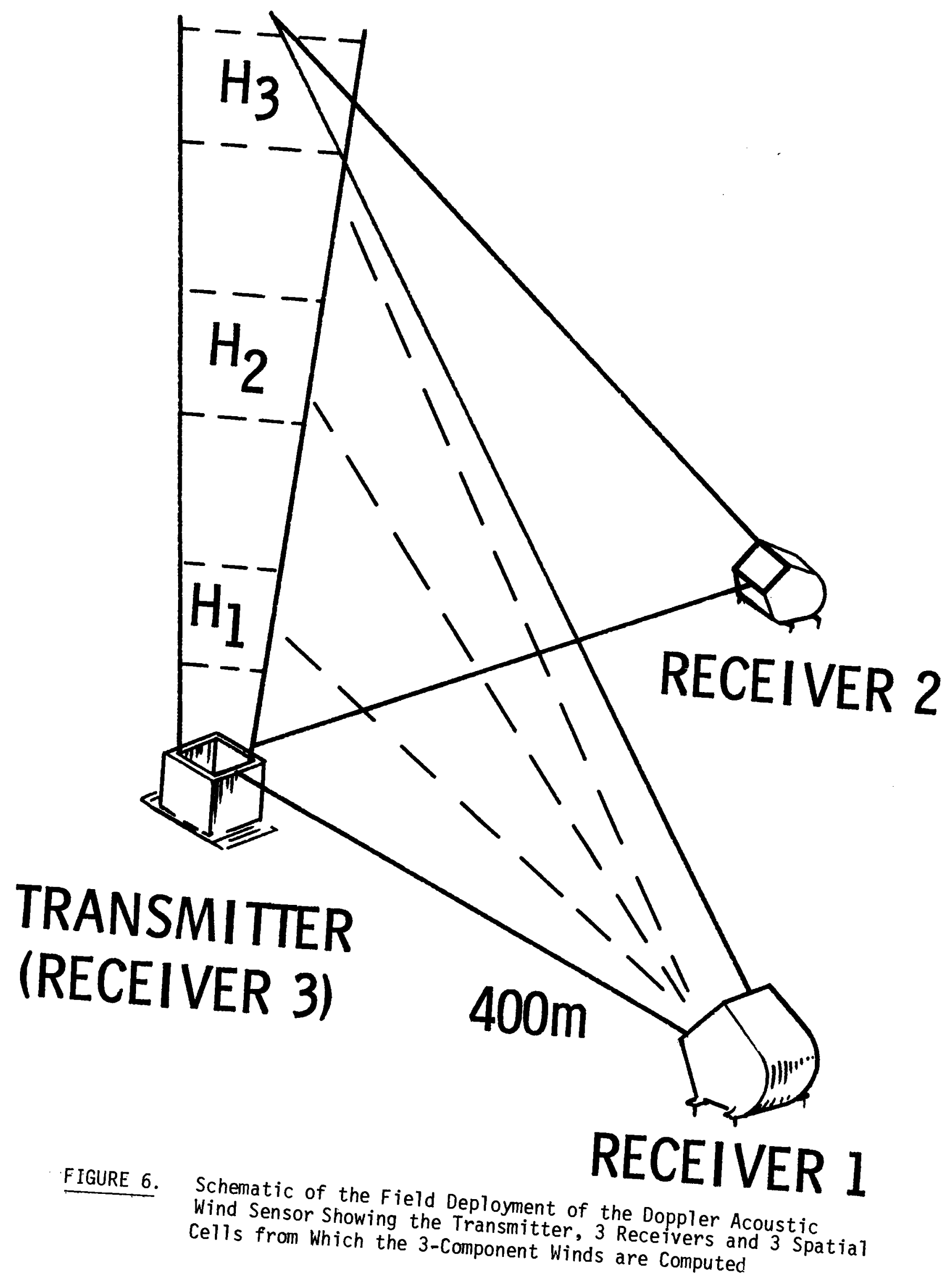


with height is provided via a teletype. Further details of the principles and application of Doppler frequency shift to determine wind velocity components are discussed by Balser, et al. (1976), Little (1969) and McAllister, et al. (1969).

A monostatic acoustic sounder (Eschosonde, Scientific Engineering Systems) was also employed during the drift study. The sounder was operated continuously during the test period, with the data from this device recorded on a strip chart. The acoustic sounder provided primarily qualitative data of temperature variability to heights of a few hundred meters in the atmosphere. These data were complementary to the tower and balloon data from some tens of meters above the ground and on up. Real-time information was displayed for general condition with respect to atmospheric stability and the presence of convection proceeding from the surface.

Sky condition, relative to the presence of visible cooling tower plumes, was recorded with an all-sky camera (35-mm Nikon camera with a 7.5-mm fisheye lens). In general, skies were clear for almost the entire duration of the test, with the exception of some occasional morning stratus clouds. Consequently, while these data would be available for further examination, no further reference will be made to them in this report.

Plume photography was also conducted during the experiment using two automatic time-lapse camera systems (16-mm Boley $\mathrm{H}-16$ Reflex movie camera with MRI Model 107-E Intervalometer for automatic time-lapse control and a 16 to $100-\mathrm{mm}$ zoom lens at the $16-\mathrm{mm}$ setting). Time lapse movies were made at a rate of about 3 frams $\min ^{-1}$. The cameras were set up at two widely separated locations with the frame centered on the cooling tower cell under intensive measurement; the wide angle 16-mm lens setting, however, usually included the entire tower or both towers. The location geometry was selected such that plume dimensions and directions could be estimated by triangulation. Visible plume lengths were, in general, very short during the test period, hence, as with respect to sky condition, no further reference is made to this phase of the study. 
In addition, standard meteorological parameters were recorded at a PG\&E meteorological facility on the plant site, southeast of the cooling towers. Data from this facility were used occasionally to fill in dropouts from the instrumented $10-\mathrm{m}$ tower record.

\section{DRIFT DEPOSITION}

Experience (Schrecker, et a1., 1975; Webb, et a1., 1977) and modeling studies (Chen, 1977; Policastro, et al., 1978) of drift from natural draft and mechanical draft cooling towers have indicated that the amount of drift material deposited downwind can be quire small. Moreover, nearly 100\% of the drift mass is deposited within 1-2 km of the tower. Therefore, the results of field measurements of drift deposition would be sensitive to the accuracy and precision of the collection methods used, the density of sampling stations employed and the magnitude and variability of background deposition other than drift. In addition, structures of various types could cause interferences in the measured deposition patterns.

The sampling configuration and deposition receptors used in the Pittsburg drift study were designed and selected to optimize the recovery of drift deposition rates from total deposition rates. To insure that the drift plume was intercepted by the downwind sampling stations, a series of arcs, roughly at distances of $1 / 4,1 / 2$ or $3 / 4 \mathrm{~km}$ from Tower $7-1$, were established downwind of the towers. An intermediate arc, roughly at 0.3 $\mathrm{km}$ from Tower 7-1, was set up after the second test day to better define the drift entering the switchyard area. Individual stations were surveyed along each arc with angular spacings of roughly 10-15 degrees with respect to one of the towers (typically Tower 7-1). The lateral extent of each arc was chosen to accomodate wind direction changes typical of normal climatological variation at Pittsburg in June as well as to allow for the extremes of each arc to provide information on background deposition. In addition, several upwind stations were also established for background data. This sampling configuration was patterned after that used by Meyer and Stanbro (1977a) in the Chalk Point Cooling Tower Project. The sampling 


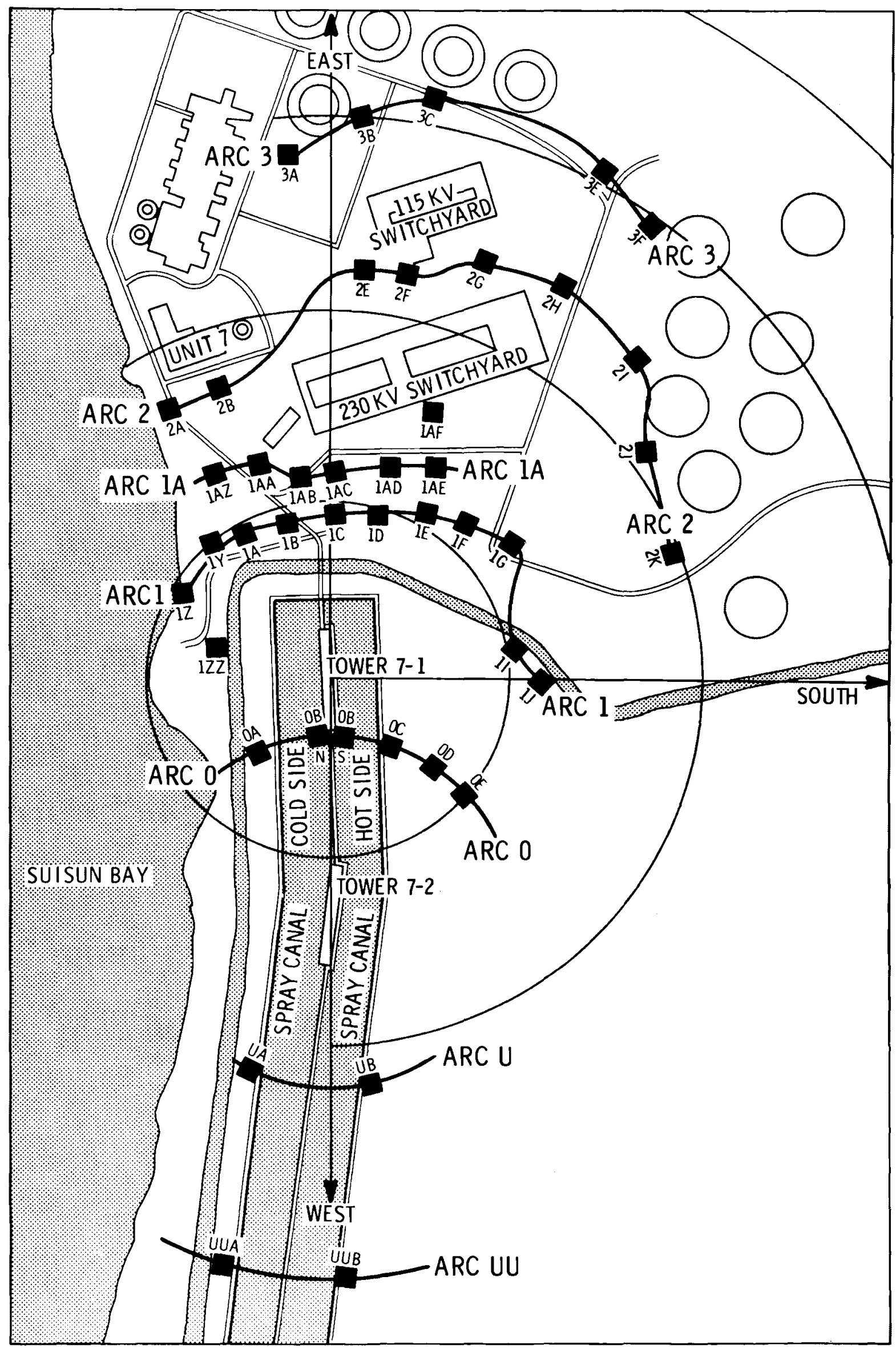

FIGURE 7. Sampling Station and Plant Layout for the PG\&E Pittsburg Power Plant Cooling Tower Drift Study 
TABLE 3. Downwind Sampling Station Identification and Location Relative to Both Cooling Towers

$$
\left(\theta=0^{\circ}=\text { North }\right)
$$

\begin{tabular}{|c|c|c|c|c|c|c|c|c|c|}
\hline $\begin{array}{c}\text { Station } \\
\text { ID } \\
\end{array}$ & $\begin{array}{l}\text { Tower } \\
\mathbf{R}_{1}(\mathrm{~m})\end{array}$ & $\begin{array}{l}7-1 \\
\theta_{3}\left({ }^{\circ}\right)\end{array}$ & $\begin{array}{c}\text { Tower } \\
\mathrm{R}_{2} \text { (m) }\end{array}$ & $\begin{array}{l}7-2 \\
\theta_{2}\left({ }^{\circ}\right)\end{array}$ & $\begin{array}{c}\text { Station } \\
\text { ID } \\
\end{array}$ & $\begin{array}{l}\begin{array}{l}\text { Tower } \\
\mathrm{R}_{1}(\mathrm{~m})\end{array} \\
\end{array}$ & $\begin{array}{l}7-1 \\
\theta_{1}\left({ }^{\circ}\right) \\
\end{array}$ & $\begin{array}{c}\text { Tower } \\
\mathrm{R}_{2}(\mathrm{~m})\end{array}$ & $\begin{array}{l}7-2 \\
\theta_{2}\left({ }^{\circ}\right)\end{array}$ \\
\hline UUA & 821 & 278 & 500 & 280 & $2 A$ & \multirow{8}{*}{$\begin{array}{l}420 \\
420 \\
560 \\
550 \\
595 \\
625 \\
605 \\
505 \\
480\end{array}$} & \multirow{8}{*}{$\begin{array}{r}60 \\
68 \\
95 \\
101 \\
110 \\
120 \\
132 \\
144 \\
158\end{array}$} & \multirow{8}{*}{$\begin{array}{l}722 \\
733 \\
884 \\
871 \\
906 \\
919 \\
871 \\
741 \\
664\end{array}$} & \multirow{3}{*}{$\begin{array}{l}73 \\
77 \\
93 \\
97\end{array}$} \\
\hline UUB & 825 & 269 & 500 & 265 & $2 B$ & & & & \\
\hline UA & 566 & 280 & 250 & 290 & $2 F$ & & & & \\
\hline UE & 573 & 267 & 250 & 260 & $2 G$ & & & & 103 \\
\hline & & & & & $2 \mathrm{H}$ & & & & 110 \\
\hline $\begin{array}{l}O A \\
O B N\end{array}$ & 125 & $\begin{array}{l}310 \\
275\end{array}$ & $\begin{array}{l}245 \\
216\end{array}$ & $\begin{array}{l}69 \\
86\end{array}$ & 21 & & & & $\begin{array}{l}117 \\
123\end{array}$ \\
\hline OBS & 110 & 256 & 219 & $\begin{array}{l}00 \\
95\end{array}$ & $2 k$ & & & & $\begin{array}{l}123 \\
131\end{array}$ \\
\hline OC & 115 & 230 & 246 & 106 & & & & & \\
\hline OD & 170 & 220 & 249 & 120 & $3 A$ & 695 & 86 & 1020 & 87 \\
\hline$O E$ & 250 & 220 & 248 & 139 & $\begin{array}{l}3 B \\
3 C\end{array}$ & $\begin{array}{l}750 \\
775\end{array}$ & $\begin{array}{r}94 \\
101\end{array}$ & $\begin{array}{l}1074 \\
1095\end{array}$ & $\begin{array}{l}92 \\
97\end{array}$ \\
\hline $1 x$ & 160 & 6 & 379 & 64 & $3 E$ & 765 & 119 & 1059 & 110 \\
\hline $12 z$ & 135 & 20 & 394 & 70 & $3 F$ & 745 & 124 & 1028 & 114 \\
\hline 12 & 230 & 37 & 501 & 68 & & & & & \\
\hline IA & $\begin{array}{l}230 \\
215\end{array}$ & $\begin{array}{l}53 \\
64\end{array}$ & $\begin{array}{l}529 \\
528\end{array}$ & $\begin{array}{l}74 \\
79\end{array}$ & Tower 7-2 & 325 & 269 & - & - \\
\hline $1 \mathrm{~B}$ & 215 & $\begin{array}{l}77 \\
9 ?\end{array}$ & 537 & 84 & Tower 7-1 & - & - & 325 & 89 \\
\hline $\begin{array}{l}1 \mathrm{IC} \\
1 \mathrm{D}\end{array}$ & $\begin{array}{l}215 \\
225\end{array}$ & $\begin{array}{r}92 \\
105\end{array}$ & $\begin{array}{l}540 \\
545\end{array}$ & $\begin{array}{l}90 \\
96\end{array}$ & & & & & \\
\hline $1 E$ & 255 & 120 & 559 & 103 & & & & & \\
\hline IF & 275 & 130 & 562 & 108 & & & & & \\
\hline 16 & 300 & 144 & 555 & 115 & & & & & \\
\hline $1 \mathrm{I}$ & 235 & 163 & 451 & 119 & & & & & \\
\hline $1 \mathrm{~J}$ & 275 & 178 & 42 & 129 & & & & & \\
\hline IAZ & 320 & 62 & 627 & 76 & & & & & \\
\hline IAA & 305 & 72 & 623 & 81 & & & & & \\
\hline $1 \mathrm{AB}$ & 270 & 84 & 594 & 87 & & & & & \\
\hline $\begin{array}{l}\text { TAC } \\
\text { IAD }\end{array}$ & $\begin{array}{l}285 \\
305\end{array}$ & $\begin{array}{r}90 \\
105\end{array}$ & $\begin{array}{l}610 \\
624\end{array}$ & $\begin{array}{l}89 \\
97\end{array}$ & & & & & \\
\hline IAE & 325 & 116 & 632 & 103 & & & & & \\
\hline $1 \mathrm{~A}$ & & I & 687 & 101 & & & & & \\
\hline
\end{tabular}


station configuration and plant layout are shown in Fig. 7. Station identification and location relative to the cooling towers are given in Table 3. All sampling sites were located to with in $\pm 10 \mathrm{~m}$.

Inspection of Fig. 7 reveals several important features. Because of structural interferences such as buildings, fences, electrical switchyards, transmission towers, etc., it was not possible or practical to set up the stations on true arc circles or at equal angular spacings. Some stations were near roads, which, if unpaved and dusty, could result in receptor contamination. Structural interferences may also affect drift deposition patterns by acting as screening agents. The effect of such interferences, of course, would be difficult to model. In an attempt to establish a visual record of potential interferences, photographs were taken of each station along a line of view towards the cooling towers. For upwind stations, photographs were taken toward the prevailing upwind direction also. These photographs and their identifications may be found in Appendix B, Sampling Station Identification.

At each sampling station, receptors were deployed to measure deposition of

- bulk mineral mass,

- drift droplet mass,

- drift droplet size distribution.

Deposition buckets were used to collect total mineral deposition. These buckets consisted of circular plastic cartons with tight-fitting snap on lids with dimensions $15 \mathrm{~cm}$ in diameter and $\sim 7 \mathrm{~cm}$ high. These type of buckets, as opposed to deposition funnels and bottles as alternatives, could be covered and stored indefinitely without additional handling, such as rinsing. Since each bucket could be rinsed in a clean laboratory environment, rather than in the field, it was felt that the chances for additional contamination were minimized. 
Large sensitive papers (293-mm dia, Millipore, Type HA filter paper, sensitized by J. H. Meyer), similar to those used by ESC for the source measurements, were employed to collect drift water droplets. Other large filter papers (Millipore HA and Whatman No. 1) were also used to collect drift. The latter papers could be developed for $\mathrm{Cl}^{-}$ion by a procedure using $\mathrm{AgNO}_{3}$ and exposure to bright light and would produce stain images similar to those produced directly by water drops on the sensitive papers.

In addition, it was felt that these untreated papers could be used as backup deposition pans. Subsequent laboratory analys is of filter blanks indicated substantial quantities of the same mineral ions that were used as drift tracers and, therefore, the untreated papers may be unsuitable as backups for the deposition pans.

Each sampling station consisted of two buckets, one sensitive paper, and one or two untreated filter papers. Each sampler was mounted on a square plywood platform $(30.5 \mathrm{~cm} \times 30.5 \mathrm{~cm})$ nailed to the top of a wooden stake driven into the ground. The platforms were approximately $1 \mathrm{~m}$ above the surface and set up along a line perpendicular to the stations radius from the cooling tower (usually Tower 7-1). The samplers were maintained in a horizontal attitude.

The sampling buckets were held in place on the platform by placing them into identical plastic cartons stapled to the platform. Small strips of masking tape were used to insure that the buckets were not blown out of their holders by gusting winds. The filter papers were premounted on square sheets of poster board $(30.5 \mathrm{~cm} \times 30.5 \mathrm{~cm})$ and covered by a second sheet that had a $27.9 \mathrm{~cm}$ circular hole cut in it. The papers were further protected by a waxed-paper cover sheet, which accompanied the packaged filter papers as separator sheets.

In addition, an attempt was made to measure air concentrations of drift downwind from the cooling towers. Rotating arm samplers similar to those described by Schrecker, et a1. (1975) were employed. Both sensitive and untreated filter papers, in the form of $2.5-\mathrm{cm} \times 15-\mathrm{cm}$ strips premounted on poster board, were exposed with this device. 
Because of the windy conditions which were encountered during the test, a few SPs were exposed at an angle to the horizontal. The tilt angle was usually between 45 and 60 degrees and the droplet stains were more nearly circular than those on the horizontal SPs. With such a sampling attitude, however, the measurements were no longer those of deposition but rather of impaction, although it was felt that these measurements would provide additional information on drift concentration and drift deposition rates.

Not all of the sampling stations shown in Figure 7 were used during any one experiment. The sampling array was centered along the mean wind direction at the beginning of a test run. The angular sector of each downwind arc, referenced to Tower 7-1, was typically 60-80 degrees, although occasionally, with two tower operation, the sector was expanded to about 100 degrees.

Based on earlier unpublished estimates and measurements of downwind drift deposition by ESC for PG\&E at the Pittsburg plant and also on measurements at Chalk Point by Meyer and Stanbro (1977a), a mininum exposure time of $2 \mathrm{hr}$ was estimated to be necessary to insure that the depositions were within the sensitivity and analysis limits. On the average, the test runs were of about $4 \mathrm{hr}$ duration, which should have been adequate to meet the analysis requirements.

Test runs were initiated on the basis of wind speed and direction. The ideal plan was to wait for light wind conditions, i.e., wind speeds $\leq 5 \mathrm{~m} \mathrm{~s}^{-1}$ and for the wind to be blowing in a direction to intercept the sampling arc. The climatological data, which was discussed earlier in the pretest summary, indicated that the prevailing winds would be westerly at speeds near $5 \mathrm{~m} \mathrm{~s}^{-1}$, or perhaps greater. Actual wind conditions were more vigorous than anticipated, as indicated in Table 1. Because of ESC's schedule constraints, it was decided that coordination of deposition measurements with source measurements were more desirable than waiting 
for some indefinite time for light winds; consequently, wind conditions were frequently less than ideal. Once the wind pattern established itself in the morning, it persisted in that direction for most of the day.

With the plume centerline established from the mean wind direction, the sampling stations to be used were identified and the deposition buckets and filter papers were pre-labeled with the date and station identification. The station array was divided into areas so that all samplers could be opened and closed within 15-20 minutes. At the beginning of the experiment, the samplers were set out and uncovered; the start time was recorded on each sampler. At the end of the experiment, the samplers were covered and the stop time was recorded. The samplers were periodically monitored. The SP samplers located nearest the cooling towers along the plume centerline often had to be covered and replaced during a run. On other occasions, such as after a wind shift, the condition of SPs located near the plume boundary was noted, along with the time, directly onto the sampler cover.

Once the experiment was underway and the deposition samplers were set out and uncovered, the rotating arm samplers were set up near stations along the plume centerline. In addition, samples of basin (cold) water and canal water were taken periodically during the test run. On several occasions, blank deposition buckets were taken. Handling procedures were identical to those used to set out and take up the field samples except that the exposure time was very brief, $\stackrel{\sim}{<} \mathrm{min}$. Whenever wind conditions permitted, the tethered-balloon system was operated just south of the cooling towers to provide vertical profiles of wind, temperature and relative humidity.

The analysis of the deposition samples were of two types:

- chemical analysis of the bulk deposition,

- droplet size distribution analysis of sensitive papers.

In addition, chemical analysis of the canal and basin water samples was also required. 
Chemical analysis was carried out using ion chromatography (Ion Chromatograph, Dionx System 10). Two instruments were available; one was used for quantitative analysis of positive ions, including $\mathrm{Na}^{+}, \mathrm{NH}_{4}^{+}$and $\mathrm{K}^{+}$, and the other was used for quantitative analysis of negative ions, including $\mathrm{Cl}^{-}, \mathrm{NO}_{3}{ }^{-}$and $\mathrm{SO}_{4}{ }^{2}$. In addition, atomic absorption spectrophotography (Atomic Absorption Spectrophotometer, Perkin Elmer 306) was used for quantitative analysis of $\mathrm{Ca}^{++}$and $\mathrm{Mg}^{++}$. The purpose in analyzing the samples for such a large number of (tracer) ions was the redundancy they provided in separating drift from background deposition by a statistical technique, which is described later in the results. The choice of ions was by no means unique. In fact the ion species, $\mathrm{NH}_{4}^{+}$and $\mathrm{NO}_{3}{ }^{-}$, were near or below the detection limits of the ion chromatographs and perhaps other species, such as metallic ions, might have provided suitable tracers also. The available instrumentation, however, was set up for this particular set of ions for several other projects and was used for the drift samples on a time shared basis. The choice of ions was one of convenience. (ESC, for example, only analyzed for $\mathrm{Na}^{+}$and $\mathrm{Mg}^{++}$in the basin water samples).

Samples were recovered from the deposition pans by rinsing with $10 \mathrm{ml}$ of double-distilled, deionized water. Since two buckets were exposed at each station, analysis could be done by combining both buckets or by using each bucket individually. Both methods were used in this study in order to

- examine sample variability from bucket to bucket, or to

- average the samples from each station.

In some cases, individual or combined samples were analyzed more than once in order to

- examine instrument reproducibility.

Each sample would then have a quantitative uncertainty that was the result of

- deposition variability

- instrument reproducibility. 
The uncertainty in the drift deposition rates arose from these two uncertainties and also the uncertainty in determining background deposition rates. Deposition bucket handling blanks were analyzed in the same manner as the regular deposition buckets.

Canal and basin water samples were analyzed on the ion chromatography and atomic absorption instruments only after dilution by factors of 10 and/or 100 with double-distilled, deionized water. Analysis of several water samples were repeated with different dilution factors to estimate reproducibility. Basin water samples obtained by ESC were also analyzed.

Drift droplet size distributions were obtained from the sensitive papers with an automated scanning and sizing device, the Quantimet 720 system. The system was interfaced with a mini-computer which allowed the measured stain sizes to be converted to droplet sizes from suitable calibration data and binned according to size category. The number and volume size distributions were stored on cassette tape for later hard copy retrieval.

Under normal magnification ( $\left.x_{1}\right)$, the lower resolution limit was a stain size $300 \mathrm{~m}$. A magnification factor of about 10 could be used for droplet stains in the range $730 \mu \mathrm{m}$. Analysis time at this $\times 10$ magnification would be roughly 100 times as great for the same area at $X 1$ magnification. Some compromises were, therefore, necessary in the actual analysis process. The main analys is effort was made at $X 1$ magnification. Intensive analyses of several SPs were made at both magnifications. The program written for the mini-computer automatically merged the distributions obtained at different magnifications and analyzed areas.

Analysis of the sensitive papers was complicated because of the non-circular, often streaky character of the stains arising from the very-windy conditions encountered during the experiment. The Quantimet system was capable of two modes of measurement in which the stain diameter or width could be obtained: 
- stain area (area method), or

- stain chord width (feret method).

The former method is applicable when the stains are circular or nearly circular, for then

$$
\text { Stain diameter } D_{S}=2(\text { stain area } / \pi)^{1 / 2} \text {. }
$$

The latter method is applicable in any case, but a problem arises in the interpretation of the measured chord length, $\mathrm{L}_{\mathrm{Ch}}$. Although little guidance was available, it was postulated that the width of an elongated stain or streak was more readily related to true droplet diameter, than, for example, its length.

In order to test this hypothesis, a study was conducted for EPRI and PNL by ESC to establish a relationship between stain sizes and shapes of known droplet sizes impacting on water sensitive papers under conditions simulating those encountered in the field, including oblique angle impaction under windy conditions. A complete discussion of this study is found elsewhere (Webb et a1., 1979); only a summary of results is given here.

The calibration experiment was conducted with a range of drop sizes that could be expected to be seen at ground level downwind of a mechanical draft cooling tower at distances between $100 \mathrm{~m}$ to $1000 \mathrm{~m}$ from the source. Five droplet sizes were chosen to cover this size range (nominally these were $200,300,400,600$ and $800 \mu \mathrm{m}$ in diameter). The droplets were allowed to impact on sensitive papers supplied by ESC. In two cases the actual papers employed in the field experiment were used as a basis for comparison.

For simulation of droplet deposition under windy conditions, the droplets were allowed to reach their natural settling velocity and to impact upon horizontally oriented sensitive papers moving at a known velocity. The horizontal velocity of the papers was obtained by positioning them on a rotating disk at known distances from its center. The area around the 
papers was covered by an absorbent material to avoid possible droplet splashing. For droplet impaction simulating $0 \mathrm{~m} \mathrm{~s}^{-1}$ wind speed conditions (i.e., vertical settling), the disk was at rest. As a reference, droplets were also allowed to impact at $45^{\circ}$ onto a paper moving at $7.5 \mathrm{~m} \mathrm{~s}^{-1}$. This was accomplished by mounting the paper on an arm connected to the motor and orienting the holder at the proper angle.

Stain dimensions were measured using techniques already discussed by ESC (see Webb, 1979). Since a variety of stain shapes were seen, a classification table (Table 4) was assembled to show how stain dimensions were acquired. In this table, images of actual droplet stains together with diagrams indicating the dimensions of stain length, $L$, and stain width, $W$, are also shown. In all cases, the stain length denotes the longer dimension of an elongated stain. Furthermore, as expected, the stain elongation was always in the direction of travel of the paper. In general, the widest portion of an unsymmetrical stain (such as the bowling pin shape) was nearest the point of first impact of the droplet.

The results of this study indicate that stain width is related consistently with droplet size and simulated horizontal wind speed, whereas stain length resulted in considerable ambiguity. Figures 8 and 9 summarize the relationship between droplet size and stain width for various impaction conditions. In general, for a constant droplet size, increasing simulated wind speed results in decreased stain width with the amount of decrease dependent on droplet size. It also appeared, that, for the range of simulated wind speeds and droplet sizes used in this study, droplets larger than about $800 \mu \mathrm{m}$ produce nearly circular stains and follow a calibration curve appropriate for settling alone. Further studies with droplets larger than $800 \mu \mathrm{m}$ would be required to verify this conjecture.

The results of the calibration study can be used to interpret the drift droplet stains measured using the feret or chord method on the Quantimet system. However another uncertainty in the determination of droplet size distributions arose. Because of wind direction variability, the elongated droplet stains and streaks were not all parallel to one 
TABLE 4. ESC Stain Shape Classification
A. CIRCULAR
$6 \frac{\bar{W}}{\mid \mathrm{L}}$
3
INCOMPLETE

B. ELLIPSE

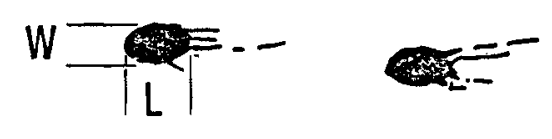

C. ELLIPSE W/TAIL DOT

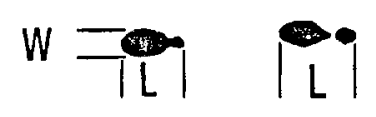

D. FOOTPRINT

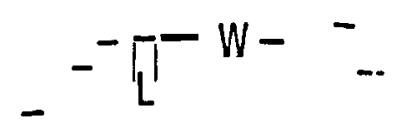

E. BOWLING PIN

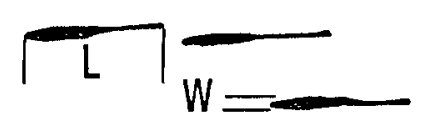

F. SPOON

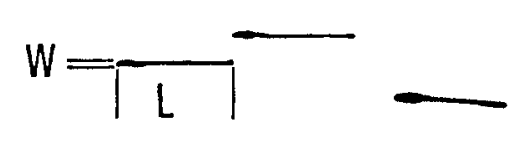

G. STREAK

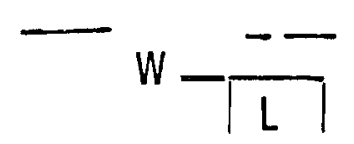




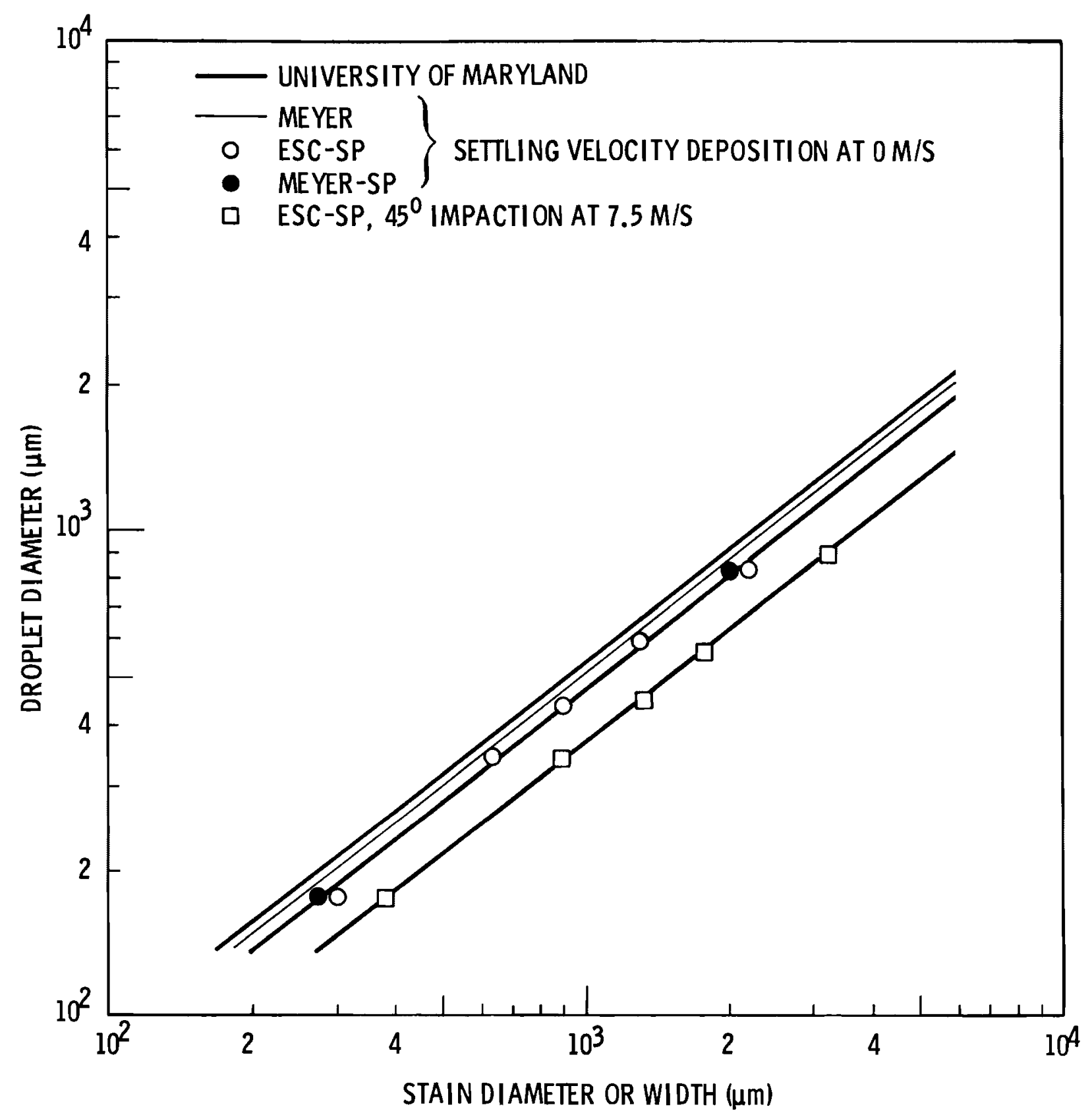

FIGURE 8. Droplet Diameter Versus Stain Diameter or Width for Droplets Settling at $0 \mathrm{~m} \mathrm{~s}-1$ Simulated Horizontal Wind Speed and for Droplets Impacting on a Tilted $45^{\circ}$ Angle Surface at $7.5 \mathrm{~m} \mathrm{~s}^{-1}$ 


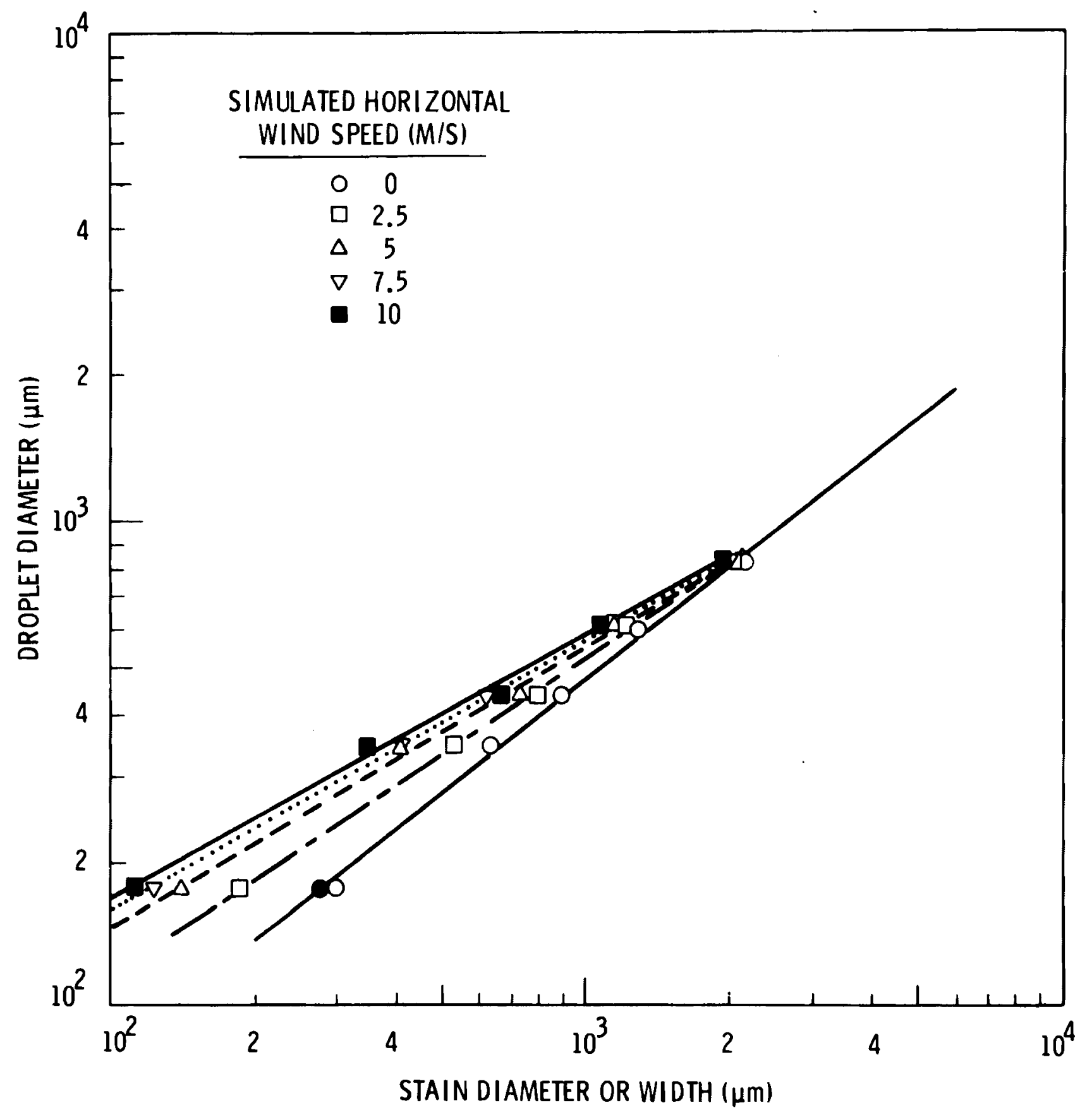

FIGURE 9. Droplet Diameter Versus Stain Diameter or Width for Droplets Impacting at Simulated Horizontal Wind Speeds of $0,2.5,5,7.5$ and $10 \mathrm{~m} \mathrm{~s}^{-1}$ 
another. Since a preferred axis or orientation of the SP was required for using the feret method, stains that were not aligned along this preferred direction would have had their apparent widths overestimated.

Most of the SP droplet stain analysis had been completed prior to the calibration study, where the calibration curve supplied by Meyer with the SPs (see curve labeled Meyer in Fig. 8) was used to convert measured stain widths to droplet diameters. Consequently, some correction of these results were required. A quantitative discussion of how these corrections were made will be given later with the results.

Procedures for analyzing the untreated filter paper samples were not developed in detail as these samples were regarded as backup to the main experiment and no analysis of these papers was carried out. In principle, these papers could be used to

- verify droplet size distributions derived from the SPS,

- verify drift deposition rates derived from the bucket samplers.

In order to analyze the untreated filter papers for droplet size information, they would have to be developed with a $\mathrm{AgNO}_{3}$ solution and exposed to bright light, and interrogated in a manner similar to that used for the SPS, although different calibration curves might be necessary.

Mineral ion deposition rates could be determined by rinsing the papers and analyzing for the various ion species as done for the deposition pans. But as described earlier, substantial interference of most of these ions was present in unexposed papers. In any case, none of the untreated papers have been analyzed by any method but will be kept in storage if later analysis is required.

A similar discussion applies to the analysis of the SPs and untreated papers (UPs) exposed on the rotating arm samplers. The SPs, of course, could be analyzed directly; the UPs could be developed or rinsed. No analysis of these samples has been carried out. These samples also are in storage until later analysis is indicated. 
Once the results of the chemical and droplet analyses were available, they were then converted to deposition rates using the actual sampling time and exposed or analyzed area. The downwind deposition patterns were obtained by combining data from all of the sampling stations in each arc. It became apparent from preliminary analysis of the test run 1, 6-16-78, that larger background values of mineral deposition were present in the data than originally anticipated, primarily as a result of the windy conditions at the site. Fortunately, the sampling procedure allowed for enought outside-the-plume stations such that, with suitable statistical procedures, it was possible to eliminate most of the influence of this variable background component.

Ratios of mineral ion mass deposition provided a convenient method to distinguish drift from non-soil, background aerosol since the ratios for drift droplets should be similar to those of the basin and/or canal water. The problem of soil contamination in the deposition pans was not so straightforward. This is because the soil had been exposed to drift deposition, and, more importantly, canal water from spray trucks as a part of PG\&E's dust abatement efforts. The upwind and off-plume stations in most cases provided a useful indicator for estimating the non-soil background. Soil samples, collected near many of the sampling stations, were examined to see if any useful method for qualitative estimates of soil/dust contamination could be found. These samples, however, were too inhomogeneous to help in the evaluation of the soil background. 


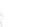

- 


\section{$\underline{\text { RESULTS }}$}

In the following sections, the results from the source characterization, meteorological conditions and deposition measurements are summarized for the June 1978 Pittsburg drift study. Source measurements are summarized for all seven tests, including all days from 15 June through 22 June (except 19 June which was used to transfer equipment from Tower 7-1 to Tower 7-2). Details of the source measurements and results are given elsewhere (Webb, 1979) and, hence, only a summary is given below. Meteorological data are presented for the period 6-15-78 through 6-24-78. Drift deposition data are presented only for test runs 1 through 6 , as 1 isted in Table 1, and include all test runs from 6-15-78 through 6-22-78, except for the 6-20-78 run (test run 8 ).

\section{SOURCE CHARACTERIZATION}

Average plant and cooling tower operational parameters obtained by ESC during the drift study are summarized in Tables 5 and 6 . Although most tests were conducted in the morning (largely because winds were lighter and the expected problems with ground-level droplet determinations were less), the tower operating parameters remained reasonably uniform. The stability in operating conditions was mainly attributable to steady plant load and a rise in wet-bulb temperature of typically $4^{\circ} \mathrm{C}$ or less during the test. The associated rise in tower operating equilibrium was typically 4 to $5^{\circ} \mathrm{C}$ as a function of time for each test day (about $5 \mathrm{hr}$ duration). Because plant load was held essentially constant for the tests, variations in cold water temperature for the test cell and tower closely paralleled those of the hot water temperature.

Average Unit \#7 plant load varied from $682 \mathrm{MW}$ to $416 \mathrm{MW}$ over the 7 days of measurements. Rated capacity for Unit \#7 is $720 \mathrm{MW}$ net. Average condenser hot water temperature varied from $30.3^{\circ} \mathrm{C}$ to $36.5^{\circ} \mathrm{C}$ over the 7 days. Cooling Tower 7-1 operated during 5 of the test days and Tower 7-2 also operated during 5 test days. (Both towers were in operation during 3 of the test days.) Cooling tower average hot water 
TABLE 5. Plant Operational Data

\begin{tabular}{|c|c|c|c|c|c|c|c|c|c|}
\hline \multirow[b]{2}{*}{ Date } & \multicolumn{2}{|c|}{ Time (PST) } & \multirow{2}{*}{$\begin{array}{l}\text { Plant Load' } \\
\text { (MWe) }\end{array}$} & \multicolumn{4}{|c|}{ Water Temperatures $\left({ }^{\circ} \mathrm{C}\right)$} & \multicolumn{2}{|c|}{ Avg Amb $\cdots t$} \\
\hline & Start & Stop & & Inlet & Outlet & Inlet & Outlet & Drybult & ivetbulb \\
\hline $6-15$ & 1130 & 1610 & 517 & 26.2 & 34.3 & 33.3 & 25.5 & 23.9 & 16.3 \\
\hline $6-16$ & 0630 & 1115 & 682 & 25.6 & 36.5 & 35.7 & 25.5 & 20.9 & 14.6 \\
\hline $6-17$ & 0630 & 1130 & 493 & 24.6 & 32.6 & 32.0 & 24.6 & 21.6 & 17.6 \\
\hline $6-18$ & 0630 & 1215 & 504 & 24.2 & 32.3 & 31.6 & 24.0 & 18.9 & 14.1 \\
\hline $6-20$ & 0745 & 1230 & 518 & 24.1 & 32.2 & 31.5 & 24.1 & 19.0 & 14.8 \\
\hline $6-21$ & 0730 & 1200 & 416 & 23.5 & 30.3 & 30.3 & 23.9 & 20.3 & 16.2 \\
\hline $6-22$ & 0700 & 1130 & 512 & 24.5 & 32.8 & 32.0 & 24.1 & 20.0 & 15.1 \\
\hline $6-24$ & 0700 & 1200 & 511 & 22.8 & 31.1 & - & - & & \\
\hline $6-25$ & 0730 & 0900 & 509 & 29.1 & 37.2 & - & - & & \\
\hline
\end{tabular}

${ }^{1}$ Average, PG\&E Plant Hour or Demand Log, Instantaneous Net generation at $1 / 2-1 \mathrm{hr}$ intervals.

2Average, PGBE Plant Hour or Demand Log, condenser circulating water temperatures. 
TABLE 6. Cooling Tower Operational Data

\begin{tabular}{|c|c|c|c|c|c|c|c|c|c|c|c|}
\hline \multirow{3}{*}{ Date } & \multirow{3}{*}{$\begin{array}{l}\text { Time } \\
\text { Start }\end{array}$} & \multirow{3}{*}{$\frac{\text { (PST) }}{\text { Stop }}$} & \multirow{3}{*}{$\begin{array}{l}\text { Tower } \\
\text { ID } \\
\end{array}$} & \multirow{3}{*}{$\begin{array}{l}\text { Operating } \\
\text { Cell1s } \\
\end{array}$} & \multirow{3}{*}{$\begin{array}{c}\text { Water } \\
\text { Flow } \\
\left(\mathrm{m}^{3} / \mathrm{s}\right) \\
\end{array}$} & \multirow{3}{*}{$\begin{array}{c}\text { Fan } \\
\text { Power } \\
(\mathrm{kw}) \\
\end{array}$} & \multicolumn{4}{|c|}{ Water Temperature $\left({ }^{\circ} \mathrm{C}\right)$} & \multirow{3}{*}{$\begin{array}{l}\text { Test } \\
\text { Cell } \\
\text { ID } \\
\end{array}$} \\
\hline & & & & & & & Al1 & ells & & Cells & \\
\hline & & & & & & & HO & $\underline{c o}$ & $\underline{\text { HOL }}$ & $\underline{\mathrm{Co}}$ & \\
\hline \multirow[t]{2}{*}{$6-15$} & 1130 & 1610 & $7-1$ & 12 & 9.5 & 153 & 33.4 & 25.0 & 33.3 & 23.7 & 7 \\
\hline & . & & $7-2$ & 10 & 10.4 & 151 & 32.2 & 27.3 & - & - & - \\
\hline \multirow[t]{2}{*}{$6-16$} & 0630 & 1115 & $7-1$ & 12 & 9.5 & 155 & 35.6 & 24.5 & 35.6 & 26.5 & 12 \\
\hline & & & $7-2$ & 10 & 10.4 & 154 & 34.6 & 27.6 & 一 & - & - \\
\hline \multirow[t]{2}{*}{$6-17$} & 0630 & 1130 & $7-1$ & 12 & 9.5 & 153 & 32.0 & 23.9 & 32.0 & 22.9 & 3 \\
\hline & & & $7-2$ & 0 & - & 一 & - & - & - & - & - \\
\hline \multirow[t]{2}{*}{$6-18$} & 0630 & 1215 & $7-1$ & 12 & 9.5 & 156 & 31.6 & 22.8 & 31.6 & 23.9 & 9 \\
\hline & & & $7-2$ & 0 & - & - & - & - & - & - & - \\
\hline \multirow[t]{2}{*}{$6-20$} & 0745 & 1230 & $7-1$ & 0 & - & - & - & - & - & - & - \\
\hline & & & $7-2$ & 10 & 10.4 & 156 & 31.2 & 25.2 & 31.5 & 22.5 & 7 \\
\hline \multirow[t]{2}{*}{$6-21$} & 0730 & 1200 & $7-1$ & 0 & - & - & - & - & - & - & - \\
\hline & & & $7-2$ & 10 & 10.4 & 151 & 29.9 & 24.9 & 30.0 & 24.7 & 12 \\
\hline \multirow[t]{2}{*}{$6-22$} & 0700 & 1130 & $7-1$ & 12 & 9.5 & 155 & 32.1 & 23.5 & - & - & - \\
\hline & & & $7-2$ & 10 & 10.4 & 154 & 31.4 & 25.6 & 31.3 & 23.7 & 3 \\
\hline \multirow[t]{2}{*}{$6-24$} & 0700 & 1200 & $7-1$ & 11 & 9.5 & ح155 & 25.8 & 21.7 & - & - & - \\
\hline & & & $7-2$ & 0 & - & - & - & - & - & - & - \\
\hline \multirow[t]{2}{*}{$6-25$} & 0730 & 0900 & $7-1$ & 11 & 9.5 & ح155 & $\sim 30.5$ & 24.1 & - & - & - \\
\hline & & & $7-2$ & 0 & - & - & - & - & - & - & - \\
\hline
\end{tabular}

${ }^{1}$ Cell 4 on $7-1$, Cells $5,10,13$ on 7-2 not operating, cell 12 on 7-1 out on 6-24, 6-25.

${ }^{2}$ Average, PG\&E Cooling Tower Data Logger paper tape printout.

${ }^{3}$ Average fan power per cell at the fan based on volt-ampere readings, fan efficiency of about 0.92 , ambient psychrometric state and other cooling tower operating parameters. 
temperatures for Towers 7-1 and 7-2 differed by as much as $1.2^{\circ} \mathrm{C}$ for those days when both towers operated while average cold water temperatures differed by as much as $3.1^{\circ} \mathrm{C}$, with Tower 7-2 yielding warmer water. The large variations (i.e., up to $5^{\circ} \mathrm{C}$ ) seen in the cold water temperature measurements made at the north-side weirs of each cooling tower were attributable to the lack of mixing and the fact that some fans were not operational (cel1 number 4 on Tower 7-1 and numbers 5, 10, and 13 on Tower 7-2).

With regard to water flow rate, little change was expected or noted for either tower. Similarly, for horsepower, variations of less than 10 percent from the average of approximately 205 horsepower were noted from cell to cell, suggesting that expected volumetric air flows could be within 3 percent from cell to cell. Because of decreasing air density, fan horsepower usually dropped approximately 2-3 percent from the morning to the afternoon. Finally, compared to design conditions, the water flow rate was approximately 19 percent below design for Tower 7-1 and 11 percent below design for Tower 7-2. Horsepower for both towers was approximately 8 percent above design.

Drift emission characteristics are based upon data derived from updraft air speed, temperature, mineral and liquid drift mass emission measurements from four cells of Tower 7-1 and three cells of Tower 7-2. The velocity profile for each cell exhibited the double-lobed structure common to fan driven flows. The highest observed average air speed was $12.7 \mathrm{~m} \mathrm{~s}^{-1}$ in one of the lobe regions and the lowest speed was $-4.6 \mathrm{~m} \mathrm{~s}^{-1}$ in the center region over the hub of the fan (see Figure 10 for a typical example). The air speed profiles were not bilaterally symmetric, as a result of the influence of external crosswinds. Calculated volumetric air flow rates were 557 $\pm 17 \mathrm{~m}^{3} \mathrm{~s}^{-1}$, which corresponds to an average updraft air velocity of $7.1 \pm$ $0.2 \mathrm{~m} \mathrm{~s}^{-1}$ for a cell exit area of $77.8 \mathrm{~m}^{2}$. Individual cooling tower air flow rates are given in Table 7 . 


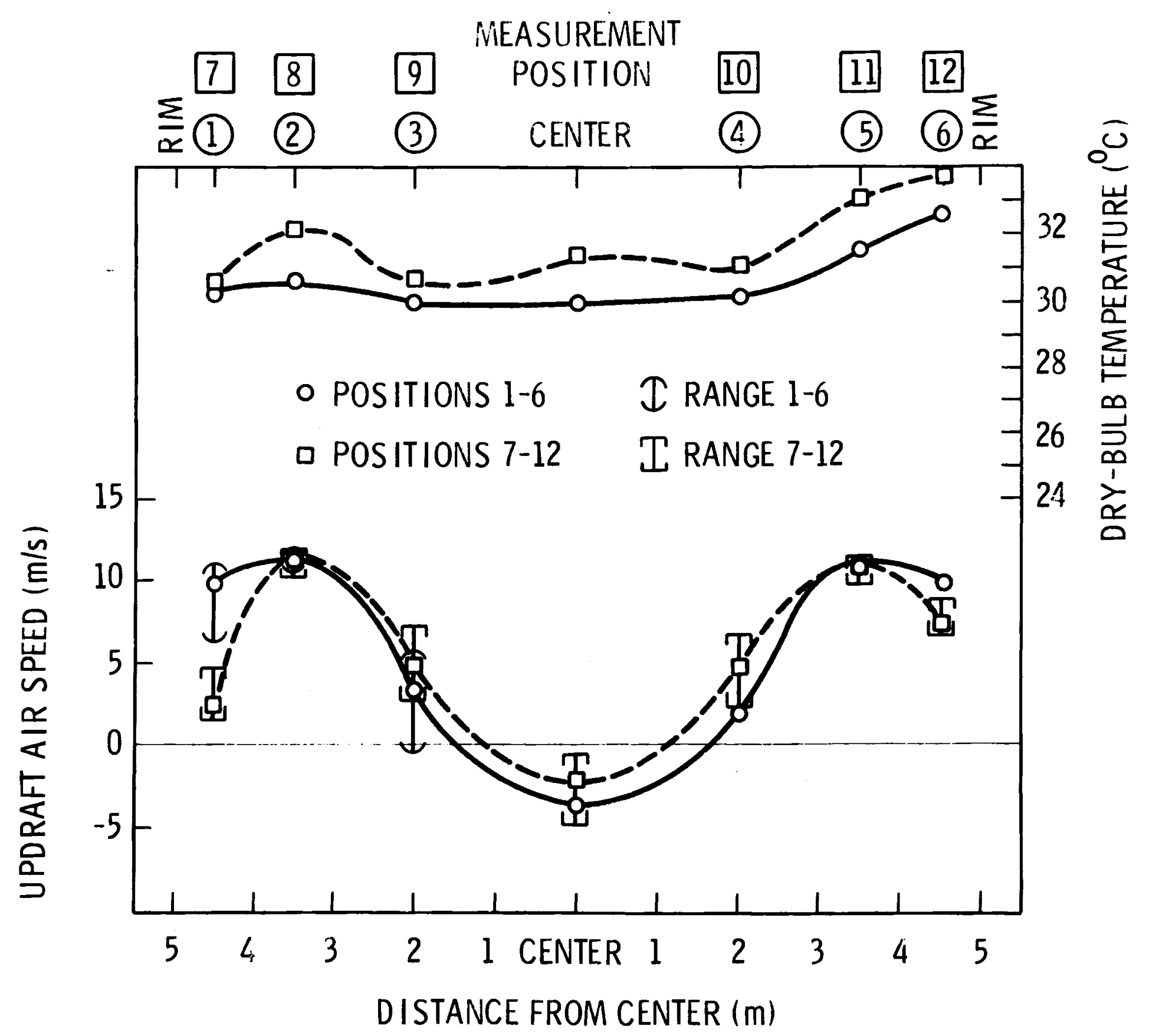

FIGURE 10. Updraft Air Speed and Dry-Bulb Temperature Profiles for the PG\&E Pittsburg Unit 7, Cooling Tower 7-1, Ce11 12, 6-16-78, 0730-1200 PDT (ESC) 


\section{TABLE 7. Cool ing Tower Air-Flow Rates (ESC)}

\begin{tabular}{cccc} 
Date & $\begin{array}{c}\text { Location } \\
\text { (Tower-Cel1) }\end{array}$ & $\begin{array}{c}\text { Net Updraft } \\
\text { Volumetric } \\
\text { Air-Flow } \\
\left(\mathrm{m}^{3} / \mathrm{s}\right)\end{array}$ & $\begin{array}{c}\text { Avg. Updraft } \\
\text { Air Velocity } \\
\text { (m/s) }\end{array}$ \\
\hline $6-15-78$ & $1-7$ & 579 & 7.4 \\
$6-16-78$ & $1-12$ & 535 & 6.9 \\
$6-17-78$ & $1-3$ & 535 & 6.9 \\
$6-18-78$ & $1-9$ & 562 & 7.2 \\
$6-20-78$ & $2-7$ & 571 & 7.3 \\
$6-21-78$ & $2-12$ & 564 & 7.2 \\
$6-22-78$ & $2-3$ & 554 & 7.1
\end{tabular}

Typical cell temperature profiles are also shown in Figure 10; these profiles were not bilaterally symmetric either, with higher temperatures toward the rim on the downwind side of the cell. As expected for saturated air, wet- and dry-bulb temperatures were the same within sensor accuracy $\left( \pm 0.2^{\circ} \mathrm{C}\right)$; dry-bulb temperatures varied by as much as $6^{\circ} \mathrm{C}$ during a given day's characterization. Temperature profiles, in general, reflected the increase in ambient temperature through the day and varied from cell to cell.

Mineral concentration of the cooling tower circulating water increased dramatically during the field test. Sodium ion concentration derived from chemical analysis of circulating water samples collected by ESC and PNL are shown in Figure 11 and Table 8. Values calculated from PG\&E's cooling tower water analysis, assuming that $\mathrm{Na}^{+}$represents $34 \%$ of the salts in seawater, are also shown. Mineral ion ratios, referenced to $\mathrm{Na}^{+}$, are listed in Table 8 for completeness. 


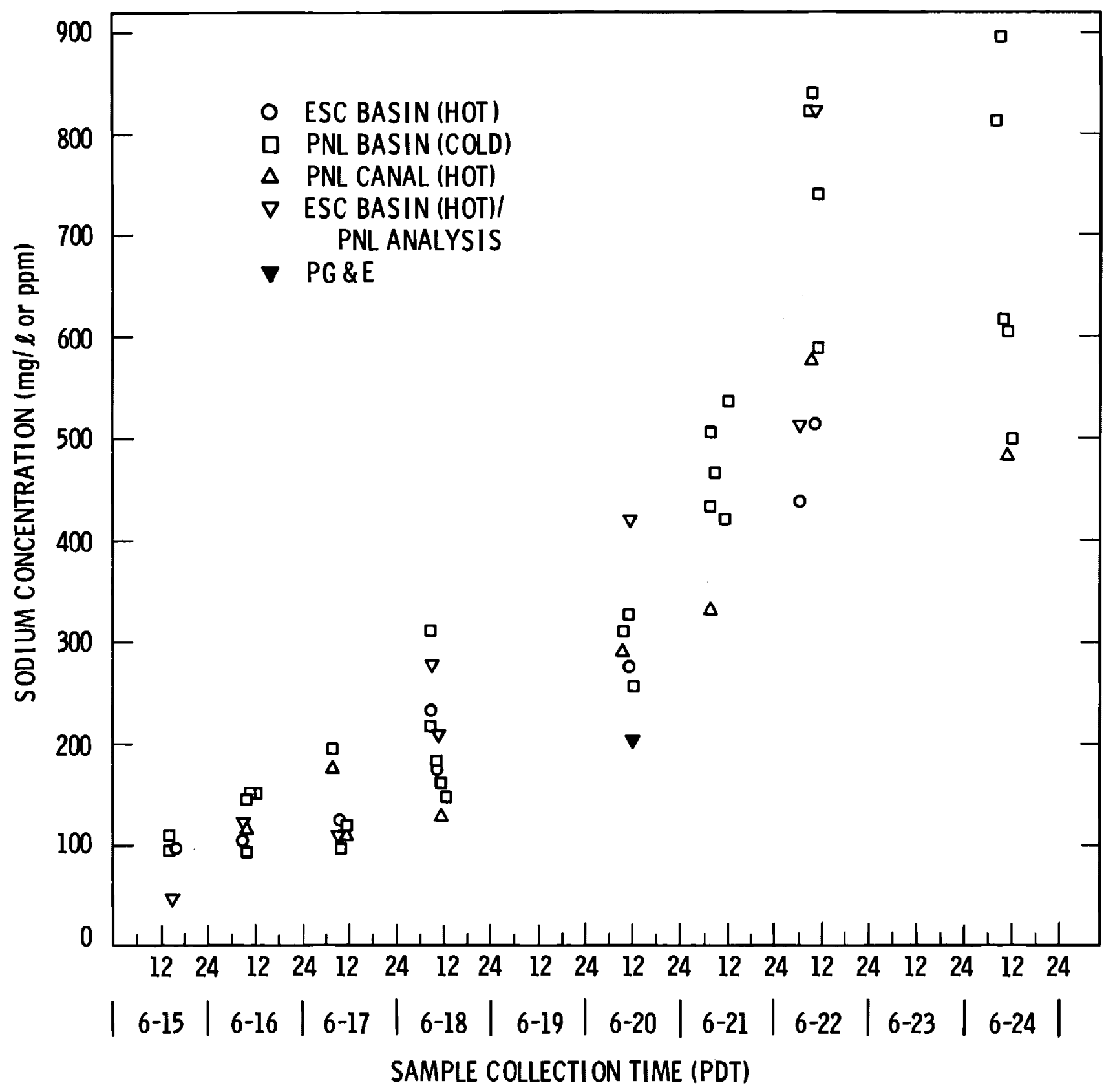

FIGURE 11. Sodium Ion Concentration of the Cooling Tower Circulating Water as a Function of Sample Collection Time and Day. The PG\&E Value is Calculated from a Total Salt Concentration, Assuming that $\mathrm{Na}^{+}$is $34 \%$ of the Salts in Seawater 
TABLE 8. Sodium Ion Concentration and Mineral Ion Concentration Ratios of the Pittsburg Unit 7 Cooling Tower Circulating Water

Mineral Ion Concentration Ratio 5

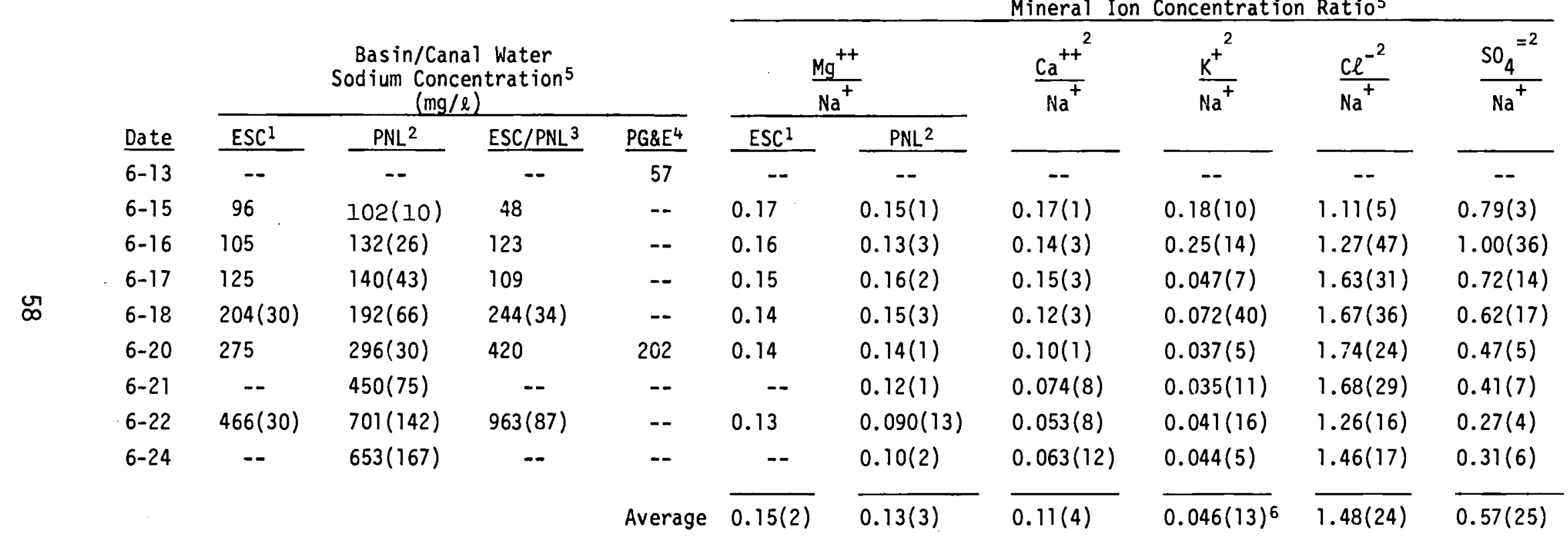

IESC analysis of ESC samples.

${ }^{2}$ PNL analysis of PNL samples.

${ }^{3}$ PNL analysis of ESC samples.

${ }^{4}$ Calculated by ESC from PG\&E analysis, assuming $\mathrm{Na}^{+}$is $34 \%$ of salts in seawater.

${ }^{5}$ Shorthand notation for standard deviation, e.g., $204(30)=204 \pm 30,0.15(1)=0.15 \pm 0.01$

${ }^{6}$ Averaged $w / 0 \quad 6-15$ and 6-16. 
As Table 8 shows, the sodium concentration increased by a factor of 5-7 during the test. In addition it appeared in the PNL samples that sodium concentration was highest at the beginning of a test run early in the morning and decreased to lower values toward the end of the experiment. While there was general agreement between the ESC and PNL values, some large discrepancies were also apparent, especially for the data of 6-22-78. The PNL analysis of the samples taken by ESC were not consistent with either the ESC or PNL analyses of their own samples, respectively.

The ratio between magnesium to sodium were in fair agreement for all days except 6-22. There also appeared to be a general decrease in the mineral ion ratios $\mathrm{Mg}^{++} / \mathrm{Na}^{+}, \mathrm{Ca}^{++} / \mathrm{Na}^{+}$, and $\mathrm{SO}_{4}{ }^{--} / \mathrm{Na}^{+}$during the experiment. Except for $6-15$ and $6-16$, the $\mathrm{K}^{+} / \mathrm{Na}^{+}$ratio was relatively constant. The $\mathrm{Ce}^{-} / \mathrm{Na}^{+}$ratio increased through 6-21 but abruptly decreased on 6-22.

An explanation to account for all of the observed changes in sodium concentration during a given test run and in the mineral ratios is lacking at the present time. Either makeup and/or blowdown rates were not as stated or the canal water was not uniformly mixed or the makeup water from Suisun Bay exhibits large diurnal variations in mineral ion concentration. The latter explanation is probably correct because of tidal action. Incoming tides would bring in saline water from San Francisco Bay while outgoing tides would result in dilution by fresh river water. Complete listings of mineral ion concentrations and mineral ion ratios for all samples are found in Appendix A, Cooling Water Mineral Analysis.

Based on the analysis of the IK samples, the sodium mass emission rates of the seven characterized cells varied in the range 1380 to 3890 $\mu \mathrm{g} \mathrm{s}^{-1}$. The average ratio of $\mathrm{Mg}^{++}$to $\mathrm{Na}^{+}$emission rates was $0.11 \pm 0.02$, compared to the basin water concentration ratio of $0.15 \pm 0.01$. An explanation for this difference cannot be given.

If no evaporation of droplets occurred in the fill region, then the mineral $\left(\mathrm{Na}^{+}\right)$mass emission rates coupled with the basin water mineral $\left(\mathrm{Na}^{+}\right)$concentration yield a liquid mass emission rate in the range 6.8 to $18.2 \mathrm{~g} \mathrm{~s}^{-1}$. The corresponding range of values of liquid mass emission from 
analysis of SP drift droplet spectra were 2.6 to $8.2 \mathrm{~g} \mathrm{~s}^{-1}$. The ratio of IK to SP 1 iquid madd emission values varied from 1.3 to 6.2 with an average value of 2.8, indicating that evaporation effects within the fill may be significant and that the mineral concentration of the drift droplets is higher than that of the circulating water (see Schrecker et al., 1975 for a discussion of similar findings in other measurement programs). The drift and mineral mass emission data are summarized in Table 9.

As discussed in detail by Webb (1979), considerable variation in mass emission rates (by as much as an order of magnitude) was found within an individual cell, from cell to cell (see also Table 9), and from day to day for the reference cells (cell 7 of each tower). Variations of these rates within a cell can be understood because of the dependence of drift emissions on updraft air speed, i.e., high updraft air speed points generally showed the highest flux values and the larger droplets, with the largest droplet observed in the 3200 to $3400 \mu \mathrm{m}$ bin. The cell-to-cell variations appear to be related to droplet leakage within the plenum, as noted in the pretest. Day-to-day variations may also be the result of irregular droplet leakage. With reference to Table 9 , it is noticed that the droplet emissions from the test cells all have mass median diameters (MMDs) greater than $500 \mu \mathrm{m}$, except for the reference cells, which have MMD values less than $100 \mu \mathrm{m}$. Since the reference cells were sampled with the 142-mm SP on a daily basis and whenever the cells were in operation, additional data was available for examining variations in the large droplet $(>90 \mu \mathrm{m})$ emissions. When these data were included into the drift mass emission spectrum, the MMD values both increased to over $500 \mu \mathrm{m}$ as seen in Table 9 . It is not presently known whether the mass peaks greater than $100 \mu \mathrm{m}$ (typically observed at 300 and $900 \mu \mathrm{m}$, respectively) are features that came and went on a daily basis or were a consequence of 1 imited sample points and sample duration of the SPS.

Because of the variability of drift mass emission from cell to cell, a representative emission rate per cell was calculated by ESC using a weighted average of those cells judged during a pretest survey to have high, medium or low emissions. The representative drift mass emission spectrum is listed 
TABLE 9. Pittsburg Plant Cooling Tower Drift

and Mineral Mass Emission Rates (ESC)

\begin{tabular}{|c|c|c|c|c|c|c|c|c|c|c|}
\hline \multirow[b]{2}{*}{ Date } & \multirow[b]{2}{*}{$\begin{array}{c}\text { Test Cell } \\
\text { (Tower Cell) }\end{array}$} & \multirow[b]{2}{*}{$\begin{array}{c}\text { Pretest } \\
\text { Rank }\end{array}$} & \multicolumn{2}{|c|}{$\begin{array}{c}\text { MME }^{1} \\
\text { Rate } \\
\left(\mu \mathrm{g}^{-1} \mathrm{~s}^{-1}\right)\end{array}$} & \multirow{2}{*}{$\begin{array}{c}\text { IK Based }{ }^{2} \\
\mathrm{DME}^{3} \\
\left(\mathrm{~g} \mathrm{~s}^{-1}\right)\end{array}$} & \multirow{2}{*}{$\begin{array}{c}\text { SP-Based } \\
\text { DME } \\
\left(g s^{-1}\right)\end{array}$} & \multirow{2}{*}{$\begin{array}{l}\text { Ratio of } \\
\text { IK to } \\
\text { SP Based }\end{array}$} & \multirow[b]{2}{*}{$\begin{array}{c}\mathrm{MMD}^{4} \\
(\mu \mathrm{m})\end{array}$} & \multicolumn{2}{|c|}{$\begin{array}{l}\text { Reference Cell } \\
\text { Data Above } 90 \mu \mathrm{m} \\
\text { DME }^{3}\end{array}$} \\
\hline & & & $\mathrm{Na}^{+}$ & $\mathrm{Mg}^{++}$ & & & & & $\begin{array}{c}\text { Rate } \\
\left(\mathrm{g} \mathrm{s}^{-1}\right)\end{array}$ & $\begin{array}{l}\mathrm{MMD}^{4} \\
(\mu \mathrm{m})\end{array}$ \\
\hline $6-15$ & $1-7$ & Medium & 1540 & 192 & 16.0 & 2.59 & 6.2 & 73 & 4.70 & 720 \\
\hline $6-16$ & $1-12$ & Medium & 1910 & 171 & 18.2 & 4.57 & 4.0 & 785 & & \\
\hline $6-17$ & $1-3$ & High & 1830 & 194 & 14.7 & 6.76 & 2.2 & 721 & & \\
\hline $6-18$ & $1-9$ & Low & 1380 & 157 & 6.77 & 4.23 & 1.6 & 638 & & \\
\hline $6-20$ & $2-7$ & Medium & 2650 & 268 & 9.64 & 4.59 & 2.1 & 81.9 & 6.48 & 503 \\
\hline $6-21$ & $2-12$ & High & $3670^{5}$ & $523^{5}$ & 10.8 & 8.17 & 1.3 & 507 & & \\
\hline $6-22$ & $2-3$ & $\mathrm{gg}^{++} / \mathrm{Na}^{+}$ & $\frac{3890}{0.11 \pm}$ & $\frac{294}{0.02}$ & 8.34 & 4.08 & 2.0 & 692 & & \\
\hline
\end{tabular}

${ }^{1}$ MME $=$ Mineral Mass Emission.

${ }^{2}$ Calculated using assumption that sodium concentration of drift droplets equals that of circulating water.

${ }^{3}$ DME = Drift Mass Emission.

${ }^{4}$ MMD $=$ Mass Median Diameter.

${ }^{5}$ Based on interpolated basin water concentration values. 
in Table 10 and is shown in Figure 12. The mass peak near $30 \mu \mathrm{m}$ probably represents droplets from the fill that have passed through the drift el iminators while the mass peaks at $300 \mu \mathrm{m}$ and beyond are probably the result of large droplets formed by leakage of water into the tower plenum.

The emission rate per cell was found to be $4.8 \mathrm{~g} \mathrm{~s}^{-1}$ resulting in a total emission rate of $124 \mathrm{~g} \mathrm{~s}^{-1}$ if all 26 cells are operating. The total emission rate corresponds to a drift fraction of $0.0006 \%$ for a total circulating water flow rate of $20 \mathrm{~m}^{3} \mathrm{~s}^{-1}$. The measured drift rate is consistent with results of other measurement programs on modern cooling towers that have current drift el iminator design.

ESC made comparisons between the SP and the PILLS droplet measurement acquired on the same cell on the same day. The photographic measurements were taken considerably after the main drift study at the Pittsburg $\mathrm{Plant}$ and, in view of the variability of droplet emissions discussed previously, there is some question as to how meaningful any comparison of results of the photographic method with those obtained by the SP and PILLS methods would be.

ESC found that emission values obtained by the PILLS and SP methods for the same droplet size category were in agreement in some instances but were in only fiar to poor agreement in others. These differences are partly the result of the limited range of the PILLS and its smaller sampling volume. The latter is especially critical for large drops $(>300 \mu \mathrm{m})$ in which the counting error is large compared with the SP system. A comparison of total emission values in the droplet size range $70-300 \mu \mathrm{m}$ is given in Table 11 summed over equivalent measurement points (see Fig. 5) of cel1 1-9 acquired on 6-18. Table 11 indicates that even in this droplet range, the PILLS system tends to underestimate the drift mass flux relative to the SP systems. The PILLS data were not used in final calculations of total cell drift mass emission rates.

Comparisons were also made between the photographic and SP techniques on the cell 1-7 but at considerably different times. The results presented in Appendix D, Summary of Calfran Droplet Data, were in a form that were 
TABLE 10. Representative Drift Mass Emission Per Cell as a Function of Droplet Size for the Pittsburg Plant Cool ing Towers (ESC)

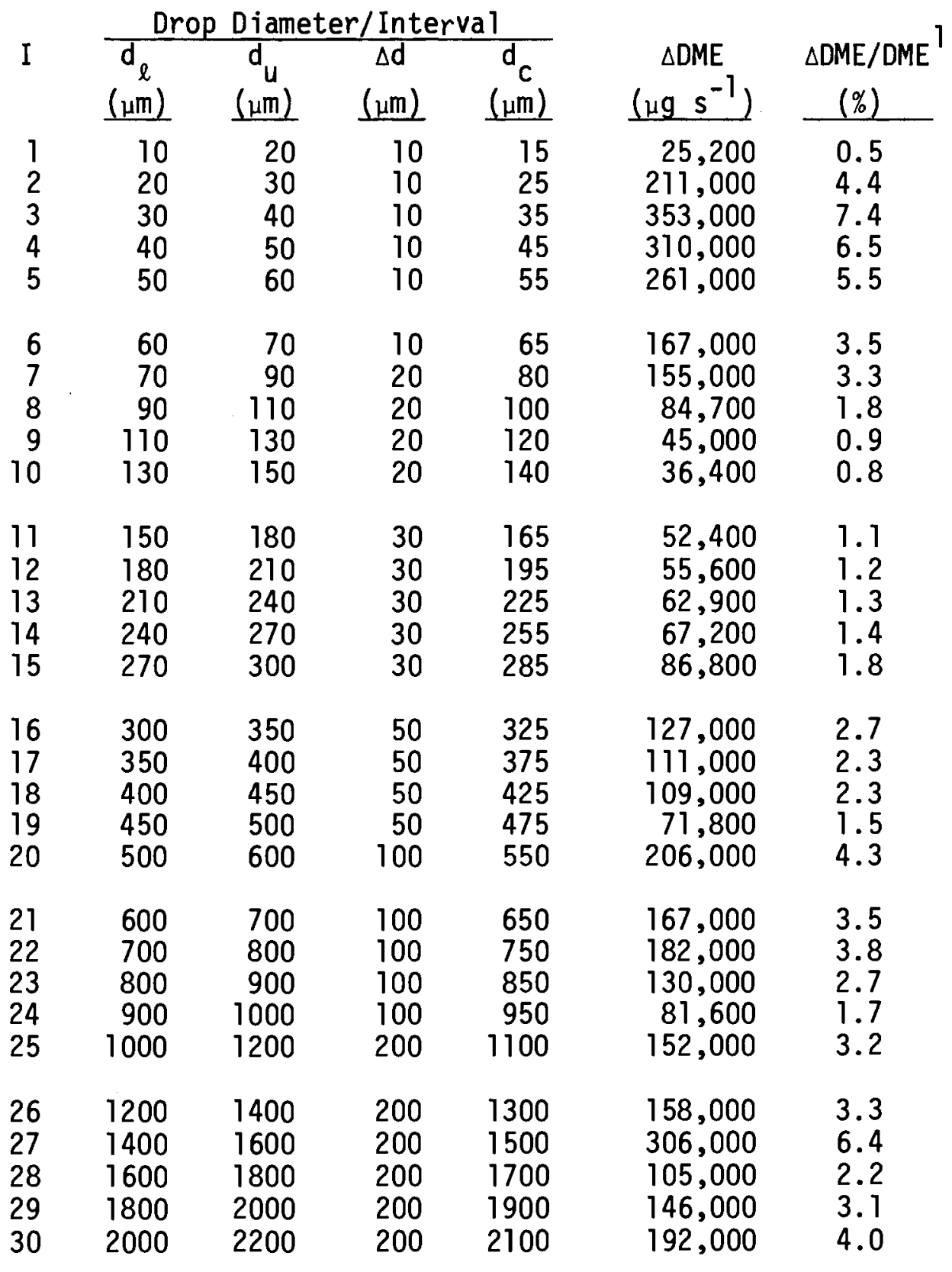


TABLE 10. (Continued)

$\begin{array}{rrrrrrr}31 & 2200 & 2400 & 200 & 2300 & 100,000 & 2.1 \\ 32 & 2400 & 2600 & 200 & 2500 & 77,000 & 1.6 \\ 33 & 2600 & 2800 & 200 & 2700 & 145,000 & 3.0 \\ 34 & 2800 & 3000 & 200 & 2900 & 80,100 & 1.7 \\ 35 & 3000 & 3200 & 200 & 3100 & 83,000 & 1.7 \\ 36 & 3200 & 3400 & 200 & 3300 & 59,200 & 1.2 \\ & & & & & & \end{array}$

Total Drift Mass Emission $4.76 \mathrm{gm} / \mathrm{sec}$ Mass Median Diameter $492 \mu \mathrm{m}$

${ }^{1}$ The summation of this column is not $100.0 \%$ due to rounding. 


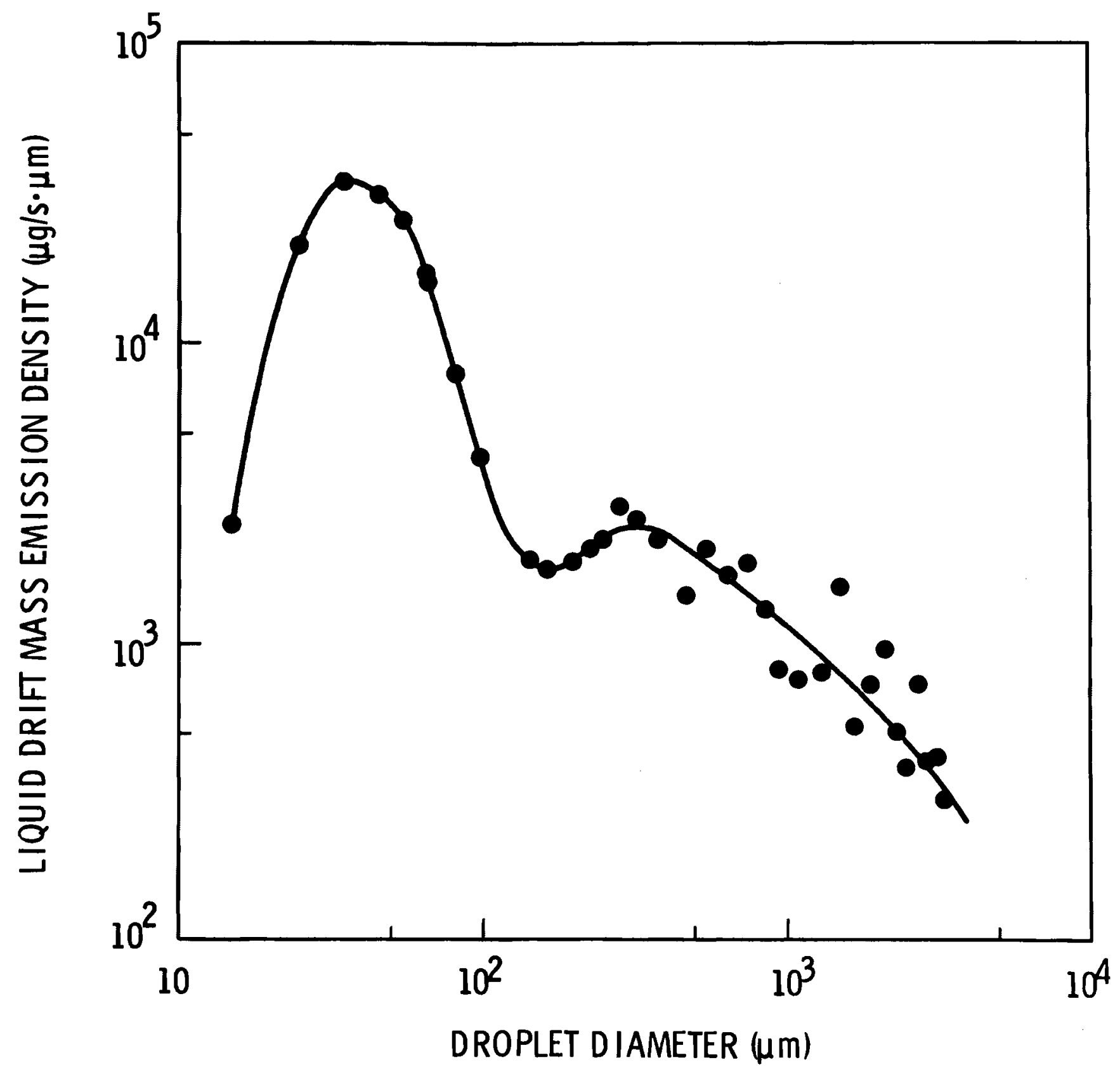

FIGURE 12. Representative Drift Mass Emission Spectrum Per Cel1 for the PG\&E Pittsburg Cooling Towers (ESC) 
TABLE 11. Comparison of SP and PILLS Drift Mass Flux in the Droplet Size Range 70-300 $\mu \mathrm{m}$. (ESC Data for Cell 1-9, 6-18-78)

\begin{tabular}{|c|c|c|c|}
\hline \multirow[t]{2}{*}{$\begin{array}{l}\text { Measurement } \\
\text { Position } 1 \\
\end{array}$} & \multicolumn{2}{|c|}{$\begin{array}{l}\text { Drift Mass Flux } \\
\left(\mu \mathrm{g} \cdot \mathrm{m}^{-2} \cdot \mathrm{s}^{-1}\right) \\
\end{array}$} & \multirow[t]{2}{*}{$\begin{array}{c}\text { Percent Difference } \\
\text { SP - PILLS } \\
\end{array}$} \\
\hline & SP & PILLS & \\
\hline $1,6,7,12$ & 26,450 & 20,940 & +21 \\
\hline $2,5,8,11$ & 46,400 & 34,650 & +25 \\
\hline $3,4,9,10$ & 9,930 & 10,500 & -6 \\
\hline Total & 82,800 & 66,100 & +20 \\
\hline
\end{tabular}

${ }^{1}$ See Fig. 5 for measurement position identification.

not convenient for a comparison with the ESC SP results. Aside from a few technical difficulties with regard to calibration and counting statistics, the droplet data indicated behavior similar to that reported by ESC, viz. mass median diameters of the droplet density size distributions were typically larger than $500 \mu \mathrm{m}$ (although minimum droplet sizes were 300 and $100 \mathrm{~m}$ respectively for the two magnifications used), and droplet densities varied considerably with location within the cell and from day to day at the same measurement points.

The Calfran droplet densities for each size range were converted to a drift mass flux by means of the ESC-acquired updraft air speed and drift droplet settling speed. In this form, the photographic data can be compared to the ESC SP data (see Table 12; see also tabulations in Appendix D). Individual drift mass flux values were at least consistent between the two methods; however there was no way of knowing whether the cooling towers were operating in similar modes during the two different test periods. This unfortunate circumstance illustrates the need for nearly simultaneous measurements in order to compare properly the various techniques. 
TABLE 12. Comparison of SP (ESC) and Photographic (Calfran) Methods for Measurement of Drift Mass Flux for Droplets Larger Than 100 um for Reference Cell 1-7 of the Pittsburg Plant Cooling Towers

\begin{tabular}{|c|c|c|c|c|c|c|c|c|c|c|c|c|c|c|}
\hline \multirow{3}{*}{$\begin{array}{l}\text { Diameter } \\
\text { Lower } \\
(\mu \mathrm{m})\end{array}$} & \multirow{3}{*}{$\begin{array}{l}\text { Range } \\
\text { Upper } \\
(\mu \mathrm{m}) \\
\end{array}$} & \multicolumn{13}{|c|}{ Drift Mass Flux $\left(\mu \mathrm{g} \cdot \mathrm{m}^{-2} \cdot \mathrm{s}^{-1}\right)$} \\
\hline & & \multicolumn{7}{|c|}{ ESC Data } & \multicolumn{6}{|c|}{ Calfran Data } \\
\hline & & $6-15^{1}$ & $\underline{6-16^{1}}$ & $6-17^{1}$ & $\underline{6-18^{1}}$ & $6-23^{1}$ & $6-23$ & Avg & $7-20$ & $7-21$ & $7-22$ & $7-25$ & $7-26$ & Avg \\
\hline 100 & 200 & 2320 & 2230 & 1240 & 1740 & 3300 & 4310 & 2520 & & & & 323 & 304 & 314 \\
\hline 200 & 300 & 2480 & 6180 & 2530 & 4630 & 3110 & 11470 & 5070 & & & & 675 & 1560 & 1120 \\
\hline 300 & 400 & 950 & 1490 & 1160 & 2460 & 2200 & 8960 & 2870 & 4990 & 5110 & 2720 & 221 & 1550 & 2120 \\
\hline 400 & 500 & 1400 & 1080 & 1220 & 1430 & 1980 & 17600 & 4120 & 9960 & 3480 & 6260 & 452 & 1810 & 4390 \\
\hline 500 & 600 & 810 & 1885 & 808 & $4 \mathrm{C4}$ & 3000 & 22400 & 4880 & 13500 & 3070 & 3680 & 0 & 1600 & 4370 \\
\hline 600 & 700 & 1330 & 670 & 665 & 1330 & 4670 & 23800 & 5410 & 12900 & 9660 & 6760 & 1260 & 0 & 6120 \\
\hline 700 & 800 & 1030 & 0 & 1025 & 2050 & 6840 & 23100 & 5670 & 13200 & 12800 & 7100 & 1850 & 3690 & 7730 \\
\hline 800 & 900 & 500 & 500 & 995 & 1990 & 5470 & 15600 & 4180 & 25000 & 5920 & 3950 & 2570 & 0 & 7490 \\
\hline 900 & 1000 & 2090 & 1395 & 0 & 0 & 2780 & 6870 & 2190 & 12200 & 13100 & 0 & 8540 & 1710 & 7110 \\
\hline 1000 & 1200 & 2150 & 4315 & 2160 & 1080 & 6470 & 8880 & 4180 & 49300 & 15700 & 4370 & 0 & 5680 & 15000 \\
\hline 1200 & 1400 & 1780 & 0 & 1780 & 1780 & 5350 & 5860 & 2760 & 31300 & 11700 & 6420 & 0 & 7630 & 11420 \\
\hline 1400 & 1600 & 2740 & 10900 & 0 & 0 & 8200 & 9010 & 5140 & 42100 & 32400 & 9150 & 5020 & 0 & 17700 \\
\hline 1600 & 1800 & & 0 & 9530 & 0 & 0 & 13100 & 3770 & 29900 & 0 & 45000 & 7770 & 0 & 16500 \\
\hline 1800 & 2000 & & 5550 & 5550 & 0 & 0 & & 1850 & 29600 & 15400 & 29000 & 10000 & 0 & 16800 \\
\hline 2000 & 2200 & & & & 7500 & 7500 & & 2500 & 71500 & 0 & 19200 & 0 & 12500 & 20640 \\
\hline 2200 & 2400 & & & & & 0 & & 0 & 15400 & 42200 & 46100 & & & 20700 \\
\hline 2400 & 2600 & & & & & 0 & & 0 & 53800 & 0 & & & & 10800 \\
\hline 2600 & 2800 & & & & & 0 & & 0 & 19200 & 30700 & & & - & 9980 \\
\hline 2800 & 3000 & & & & & 19750 & & 3290 & 22600 & 0 & & & & 4520 \\
\hline 3000 & 3200 & & & & & & & & 0 & 0 & & & & 0 \\
\hline 3200 & 3400 & & & & & & & & 25600 & 37600 & & & & 12600 \\
\hline Total ( & $>100 \mu \mathrm{m})$ & 19600 & 36200 & 28700 & 26400 & 80600 & 171000 & 60400 & - & - & - & 37700 & 38000 & - \\
\hline Total ( & $>300 \mu \mathrm{m})$ & 14800 & 27800 & 24900 & 20000 & 74210 & 155000 & 52800 & 482000 & 239000 & 189000 & 37700 & 36100 & 197000 \\
\hline
\end{tabular}




\section{METEOROLOGY}

Meteorological conditions were quite similar during the test period. Generally fair weather prevailed with clear skies, warm temperatures and moderate to high winds. Since all the test runs, except for test run 3 , 6-15-78, were conducted during the morning hours, surface temperatures increased from an average low value of about $15^{\circ} \mathrm{C}$ at the beginning of a test run to an average high of about $23^{\circ} \mathrm{C}$ at the end of it. Relative humidities decreased from $\sim 75 \%$ to $\sim 50 \%$ during the same time period. Winds generally increased by $1-3 \mathrm{~m} \mathrm{~s}^{-1}$ with an average value during the test period of about $6 \mathrm{~m} \mathrm{~s}^{-1}$. Wind direction was from the west $\left(270^{\circ}\right)$ during the first three test days, but was from the WSW $\left(245^{\circ}\right)$ for the remainder of the test period. Standard deviations of wind direction were quite low,

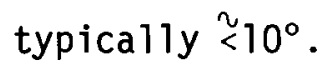

The warmest and calmest day was on 6-17-78. Some cloudiness occurred during the late morning hours. Winds were noticably lower, averaging $\sim 4 \mathrm{~m} \mathrm{~s}^{-1}$. Temperatures ranged from $17^{\circ} \mathrm{C}$ to $26^{\circ} \mathrm{C}$ with an average of around $20^{\circ} \mathrm{C}$. The coolest day occurred on $6-20$ (average temperature $213^{\circ} \mathrm{C}$ ); it was also the most windy $\left(\sim 8 \mathrm{~m} \mathrm{~s}^{-1}\right)$. Skies were cloudy (scattered) and relative humidity was high $(\sim 85 \%)$.

Averaged values of dry-bulb temperature, relative humidity, and wind speed and direction were computed and synthesized from data obtained from the 10-m meteorological tower, tethered balloon system and the PG\&E onplant meteorological facility.

Hourly and 10-min averaging periods were chosen. The hourly meteorological data are displayed in Table 13; the averages are centered on the hour. The 10-min averages are given in Appendic $C$, Meteorological Summaries.

Vertical profiles of temperature, wind and relative humidity were also derived from the tethered balloon system measurements. These data are also summarized in Appendix C. Generally, wind speeds were too great to effectively use the system. 
TABLE 13. Hourly Average Meteorological Data for the Pittsburg Power Plant Site During the June METER Drift Study

\begin{tabular}{|c|c|c|c|c|c|}
\hline Date & Time(PST) & Temp. $\left(C^{\circ}\right)$ & R.H. (\%) & Wind Speed $\left(\mathrm{ms}^{-1}\right)$ & Wind Direc. $\left({ }^{\circ}\right)$ \\
\hline 15 June & $\begin{array}{l}0700 \\
0800 \\
0900 \\
1000 \\
1100 \\
1200 \\
1300 \\
1400 \\
1500 \\
1600 \\
1700 \\
1800\end{array}$ & $\begin{array}{l}14.6 \\
16.8 \\
19.0 \\
20.7 \\
21.8 \\
22.4 \\
23.0 \\
23.5 \\
25.2 \\
26.3 \\
26.8 \\
24.7\end{array}$ & $\begin{array}{l}65.7 \\
57.7 \\
50.0 \\
46.3 \\
45.7 \\
45.7 \\
43.7 \\
41 \\
43 \\
40 \\
30 \\
35\end{array}$ & $\begin{array}{l}4.5 \\
4.8 \\
4.7 \\
4.5 \\
4.7 \\
5.6 \\
6.2 \\
6.8 \\
6.8 \\
6.8 \\
6.3 \\
7.2\end{array}$ & $\begin{array}{l}258.3 \\
256.7 \\
251.7 \\
206.7 \\
281.7 \\
295.0 \\
298.3 \\
300.4 \\
295.6 \\
275.3 \\
248.9 \\
219.6\end{array}$ \\
\hline 16 June & $\begin{array}{l}0700 \\
0800 \\
0900 \\
1000 \\
1100 \\
1200 \\
1300\end{array}$ & $\begin{array}{l}14.9 \\
16.8 \\
19.0 \\
21.1 \\
22.8 \\
24.1 \\
25.0\end{array}$ & $\begin{array}{l}68.7 \\
61.3 \\
52.0 \\
45.0 \\
40.7 \\
37.3 \\
34.7\end{array}$ & $\begin{array}{l}4.1 \\
4.4 \\
4.8 \\
4.8 \\
5.1 \\
5.0 \\
5.0\end{array}$ & $\begin{array}{l}266.7 \\
266.7 \\
265.0 \\
266.7 \\
268.3 \\
278.3 \\
388.3\end{array}$ \\
\hline 17 June & $\begin{array}{l}0700 \\
0800 \\
0900 \\
1000 \\
1100 \\
1200 \\
1300\end{array}$ & $\begin{array}{l}17.4 \\
18.7 \\
20.2 \\
21.3 \\
22.8 \\
24.3 \\
26.1\end{array}$ & $\begin{array}{l}59.0 \\
56.7 \\
56.3 \\
55.7 \\
54.7 \\
47.0 \\
36.7\end{array}$ & $\begin{array}{l}2.7 \\
2.1 \\
3.0 \\
4.1 \\
5.0 \\
5.4 \\
5.4\end{array}$ & $\begin{array}{l}156.7 \\
191.7 \\
253.3 \\
290.4 \\
295.0 \\
292.5 \\
292.5\end{array}$ \\
\hline 18 June & $\begin{array}{l}0700 \\
0800 \\
0900 \\
1000 \\
1100 \\
1200 \\
1300\end{array}$ & $\begin{array}{l}14.8 \\
15.7 \\
16.8 \\
17.9 \\
19.4 \\
20.7 \\
21.8\end{array}$ & $\begin{array}{l}71.0 \\
67.0 \\
63.0 \\
60.0 \\
55.7 \\
52.7 \\
50.0\end{array}$ & $\begin{array}{l}7.2 \\
7.2 \\
7.0 \\
7.0 \\
7.0 \\
7.5 \\
7.7\end{array}$ & $\begin{array}{l}235.0 \\
232.3 \\
236.7 \\
240.0 \\
245.0 \\
253.3 \\
256.7\end{array}$ \\
\hline 19 June & $\begin{array}{l}0700 \\
0800 \\
0900 \\
1000 \\
1100 \\
1200 \\
1300\end{array}$ & $\begin{array}{l}14.9 \\
17.2 \\
19.4 \\
21.7 \\
23.0 \\
23.8 \\
24.1\end{array}$ & $\begin{array}{l}80.3 \\
71.3 \\
63.0 \\
54.7 \\
53.0 \\
53.0 \\
52.3\end{array}$ & $\begin{array}{l}4.3 \\
4.1 \\
4.4 \\
4.5 \\
5.4 \\
6.2 \\
5.9\end{array}$ & $\begin{array}{l}267.5 \\
260.0 \\
253.3 \\
253.3 \\
268.3 \\
285.0 \\
298.4\end{array}$ \\
\hline
\end{tabular}




\section{TABLE 13. (Continued)}

\begin{tabular}{|c|c|c|c|c|c|}
\hline Date & Time (PST) & Temp. $\left(C^{\circ}\right)$ & R.H. (\%) & Wind Speed $\left(m s^{-1}\right)$ & Wind Direc. $\left({ }^{\circ}\right)$ \\
\hline 20 June & $\begin{array}{l}0700 \\
0800 \\
0900 \\
1000 \\
1100 \\
1200 \\
1300\end{array}$ & $\begin{array}{l}12.9 \\
12.6 \\
12.6 \\
13.3 \\
14.6 \\
15.7 \\
17.2\end{array}$ & $\begin{array}{l}85.3 \\
87.7 \\
90.0 \\
86.7 \\
80.0 \\
71.7 \\
65.0\end{array}$ & $\begin{array}{l}7.2 \\
7.2 \\
7.5 \\
8.0 \\
7.7 \\
7.5 \\
6.9\end{array}$ & $\begin{array}{l}237.1 \\
237.4 \\
240.0 \\
242.3 \\
247.0 \\
245.0 \\
244.4\end{array}$ \\
\hline 21 June & $\begin{array}{l}0700 \\
0800 \\
0900 \\
1000 \\
1100 \\
1200 \\
1300\end{array}$ & $\begin{array}{l}14.4 \\
16.1 \\
17.7 \\
19.6 \\
21.3 \\
23.0 \\
23.7\end{array}$ & $\begin{array}{l}79.3 \\
73.3 \\
67.0 \\
60.3 \\
55.0 \\
50.0 \\
46.0\end{array}$ & $\begin{array}{l}4.1 \\
4.1 \\
6.3 \\
6.2 \\
6.3 \\
5.4 \\
5.4\end{array}$ & $\begin{array}{l}265.0 \\
250.4 \\
245.3 \\
245.0 \\
245.7 \\
246.0 \\
270.0\end{array}$ \\
\hline 22 June & $\begin{array}{l}0700 \\
0800 \\
0900 \\
1000 \\
1100 \\
1200 \\
1300\end{array}$ & $\begin{array}{l}14.6 \\
15.7 \\
16.8 \\
18.5 \\
20.7 \\
22.4 \\
23.0\end{array}$ & $\begin{array}{l}72.4 \\
69.5 \\
67.3 \\
60.4 \\
55.2 \\
49.1 \\
48.0\end{array}$ & $\begin{array}{l}6.3 \\
5.6 \\
6.8 \\
6.8 \\
6.3 \\
6.3 \\
8.1\end{array}$ & $\begin{array}{l}211.4 \\
227.0 \\
247.5 \\
245.0 \\
246.4 \\
252.4 \\
255.8\end{array}$ \\
\hline 23 June & $\begin{array}{l}0700 \\
0800 \\
0900 \\
1000 \\
1100 \\
1200 \\
1300\end{array}$ & $\begin{array}{l}14.0 \\
14.6 \\
15.7 \\
17.4 \\
19.0 \\
20.7 \\
22.4\end{array}$ & $\begin{array}{l}80.1 \\
80.0 \\
74.0 \\
68.9 \\
61.4 \\
53.9 \\
47.4\end{array}$ & $\begin{array}{r}6.3 \\
9.9 \\
12.0 \\
11.0 \\
8.3 \\
6.5 \\
7.0\end{array}$ & $\begin{array}{l}244.0 \\
245.6 \\
243.2 \\
244.5 \\
248.0 \\
236.0 \\
230.3\end{array}$ \\
\hline 24 June & $\begin{array}{r}0700 \\
0800 \\
0900 \\
.1000 \\
1100 \\
1200 \\
1300\end{array}$ & $\begin{array}{l}13.4 \\
14.6 \\
16.8 \\
18.5 \\
20.2 \\
22.4 \\
23.1\end{array}$ & $\begin{array}{l}75.0 \\
68.6 \\
61.4 \\
52.3 \\
47.1 \\
42.3 \\
39.7\end{array}$ & $\begin{array}{l}9.0 \\
6.5 \\
8.3 \\
9.0 \\
7.7 \\
7.2 \\
7.0\end{array}$ & $\begin{array}{l}235.0 \\
249.7 \\
238.0 \\
256.0 \\
250.2 \\
248.0 \\
254.7\end{array}$ \\
\hline
\end{tabular}

1 Averages centered on the hour. 
DRIFT DEPOSITION

Droplet Deposition Patterns

The results of the SP interrogations for the first 6 test runs and the near tower test (test run $\mathrm{x}$ ) are listed in Tables 14-20 and shown in Figs. 13-18. Detailed droplet spectra are found in Appendix E, Tables E1.1 - El.X. Peak drift droplet mass deposition rates for each of the test runs are shown in Fig. 19 as a function of downwind distance.

Before discussing each individual test run, some additional comments on analysis procedures and interpretations not covered earlier are in order. In the tabulations and graphs, a range of values for the droplet mass deposition rates is given. This range of values arises from several considerations.

To begin with, a majority of the SP interrogations had been completed before the completion of the SP calibration study. For these interrogations, the relationship (calibration equation) between true droplet size and stain width or diameter was the curve supplied by Meyer for droplets settling at terminal velocity at normal incidence (see Fig. 8). Furthermore, measured stain widths were overestimated because the droplet stains and streaks were not all aligned along the mean axis of the SP. Several interrogation tests were carried out subsequent to the calibration study to examine this effect in detail. The results of these tests are shown in Fig. 20.

For the interrogation test the SP sample, $\mathrm{OA}-2$ ( $T i l t$ ) of $6-21-78$, was reanalyzed. ESC evaluated the droplet size distribution of this SP using their own analysis methods and calibration curve (terminal droplet settling velocity at normal incidence). Their results are shown in Fig. 20 as curve a. For comparison, the first PNL interrogation (10-27-78) results are shown as curve $b$ (note that the ordinate explicitly shows a deposition rate, independent of analysis area). Several differences are immediately obvious; these are: 
TABLE 14. Drift Droplet Deposition Patterns for Test Run 1, $6-16-78$

(see Table El.1 for detailed droplet spectra)

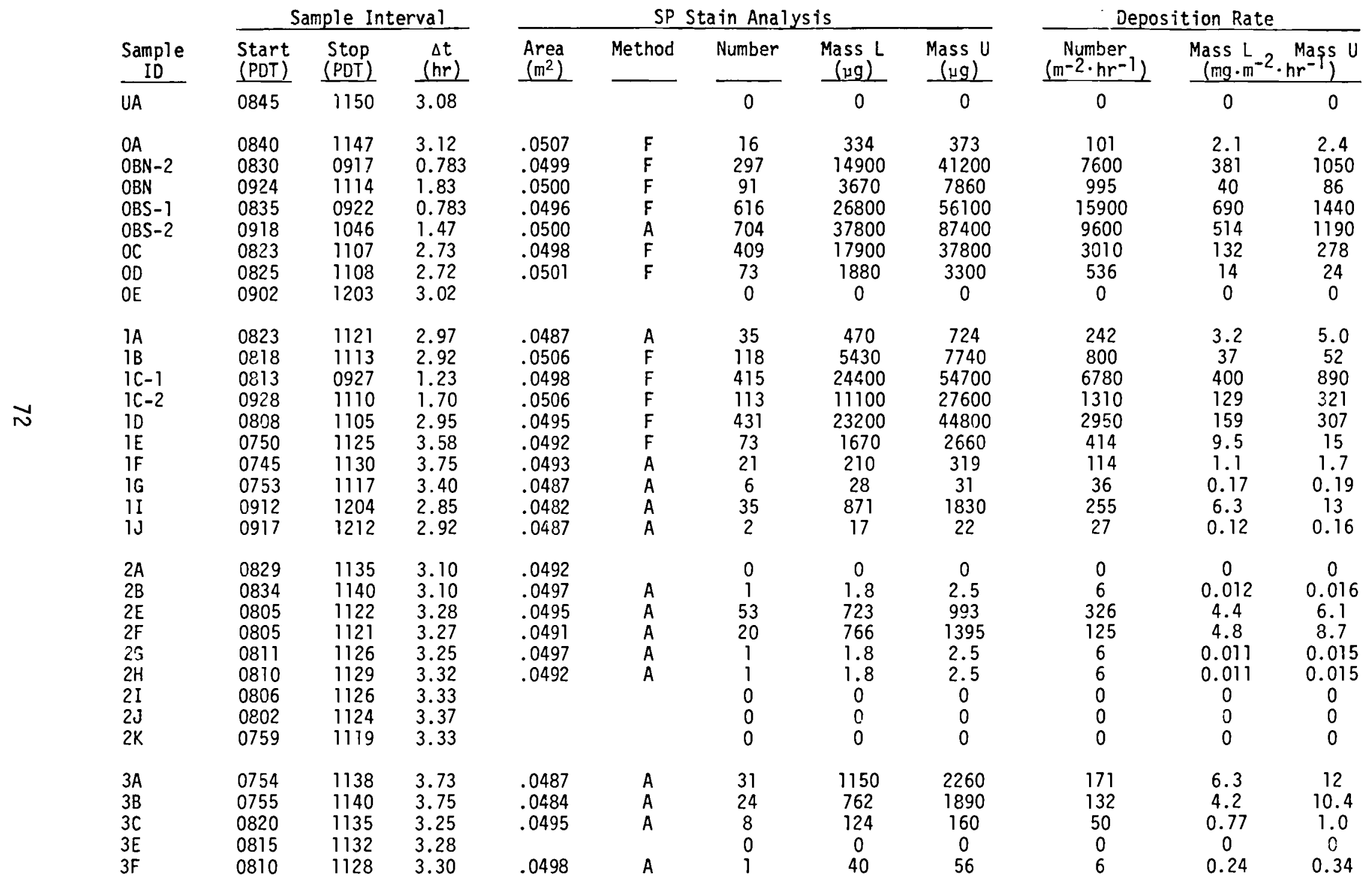


TABLE 15. Drift Droplet Deposition Patterns for Test Run 2, 6-17-78 (see Table El.2 for detailed droplet spectra)

\begin{tabular}{|c|c|c|c|c|c|c|c|c|c|c|c|}
\hline & \multicolumn{3}{|c|}{ Sample Interval } & \multicolumn{5}{|c|}{ SP Stain Analysis } & \multicolumn{3}{|c|}{ Deposition Rate } \\
\hline $\begin{array}{c}\text { Sample } \\
\text { ID } \\
\end{array}$ & $\begin{array}{l}\text { Start } \\
\text { (PDT) }\end{array}$ & $\begin{array}{l}\text { Stop } \\
\text { (PDT) }\end{array}$ & $\begin{array}{c}\Delta t \\
(h r) \\
\end{array}$ & $\begin{array}{l}\text { Area } \\
\left(m^{2}\right) \\
\end{array}$ & Method & Number & $\begin{array}{c}\text { Mass L } \\
(\mu g) \\
\end{array}$ & $\begin{array}{c}\text { Mass U } \\
(\mu g) \\
\end{array}$ & $\begin{array}{c}\text { Number } \\
\left(\mathrm{m}^{-2} \cdot \mathrm{hr}^{-1}\right)\end{array}$ & $\begin{array}{r}\text { Mass L } \\
(\mathrm{mg} \cdot \mathrm{m} \\
\end{array}$ & $\begin{array}{c}\text { Mass U } \\
\left.h r^{-1}\right)\end{array}$ \\
\hline $\begin{array}{l}O A \\
O B N \\
O C\end{array}$ & $\begin{array}{l}0945 \\
0941 \\
0935\end{array}$ & $\begin{array}{l}1304 \\
1221 \\
1308\end{array}$ & $\begin{array}{l}3.32 \\
2.67 \\
3.55\end{array}$ & .0490 & A & $\begin{array}{l}0 \\
0 \\
2\end{array}$ & $\begin{array}{c}0 \\
0 \\
68\end{array}$ & $\begin{array}{c}0 \\
0 \\
96\end{array}$ & $\begin{array}{c}0 \\
0 \\
11.5\end{array}$ & $\begin{array}{c}0 \\
0 \\
0.39\end{array}$ & $\begin{array}{c}0 \\
0 \\
0.55\end{array}$ \\
\hline $\begin{array}{l}1 \mathrm{C} \\
10-1 \\
10-2 \\
1 E \\
1 F\end{array}$ & $\begin{array}{l}0842 \\
0846 \\
1002 \\
0922 \\
0930\end{array}$ & $\begin{array}{l}1301 \\
1001 \\
1239 \\
1243 \\
1247\end{array}$ & $\begin{array}{l}4.32 \\
1.25 \\
2.62 \\
3.35 \\
3.28\end{array}$ & $\begin{array}{l}.0483 \\
.0496 \\
.0495 \\
.0495\end{array}$ & $\begin{array}{l}A \\
A \\
F \\
F\end{array}$ & $\begin{array}{c}0 \\
630 \\
215 \\
150 \\
35\end{array}$ & $\begin{array}{c}0 \\
17200 \\
9460 \\
2770 \\
1790\end{array}$ & $\begin{array}{c}0 \\
32100 \\
18700 \\
4070 \\
4140\end{array}$ & $\begin{array}{c}0 \\
10400 \\
1650 \\
905 \\
220\end{array}$ & $\begin{array}{c}0 \\
285 \\
73 \\
17 \\
11\end{array}$ & $\begin{array}{c}0 \\
532 \\
144 \\
25 \\
25\end{array}$ \\
\hline $\begin{array}{l}\text { TAA } \\
\text { IAB } \\
\text { IAC } \\
\text { IAD } \\
\text { IAE } \\
\text { IAF }\end{array}$ & $\begin{array}{l}0907 \\
.0903 \\
0852 \\
0923 \\
1036\end{array}$ & $\begin{array}{l}1255 \\
1251 \\
1230 \\
1223 \\
1306\end{array}$ & $\begin{array}{l}3.80 \\
3.80 \\
3.63 \\
3.00 \\
2.50\end{array}$ & $\begin{array}{l}.0496 \\
.0492 \\
.0482\end{array}$ & $\begin{array}{l}F \\
F \\
F\end{array}$ & $\begin{array}{c}0 \\
0 \\
0 \\
70 \\
199 \\
5\end{array}$ & $\begin{array}{c}0 \\
0 \\
0 \\
4230 \\
5840 \\
129\end{array}$ & $\begin{array}{c}0 \\
0 \\
0 \\
10300 \\
10900 \\
201\end{array}$ & $\begin{array}{c}0 \\
0 \\
0 \\
390 \\
1350 \\
41\end{array}$ & $\begin{array}{c}0 \\
0 \\
0 \\
23 \\
40 \\
1.1\end{array}$ & $\begin{array}{c}0 \\
0 \\
0 \\
57 \\
74 \\
1.7\end{array}$ \\
\hline $\begin{array}{l}2 E \\
2 F \\
2 G \\
2 H\end{array}$ & $\begin{array}{l}0858 \\
0847 \\
0851 \\
0854\end{array}$ & $\begin{array}{l}1305 \\
1308 \\
1310 \\
1313\end{array}$ & $\begin{array}{l}4.12 \\
4.35 \\
4.32 \\
4.32\end{array}$ & $\begin{array}{l}.0492 \\
.0495\end{array}$ & $\begin{array}{l}F \\
F\end{array}$ & $\begin{array}{l}0 \\
0 \\
7 \\
8\end{array}$ & $\begin{array}{c}0 \\
0 \\
110 \\
179\end{array}$ & $\begin{array}{c}0 \\
0 \\
140 \\
265\end{array}$ & $\begin{array}{c}0 \\
0 \\
33 \\
37\end{array}$ & $\begin{array}{c}0 \\
0 \\
0.52 \\
0.84\end{array}$ & $\begin{array}{c}0 \\
0 \\
0.66 \\
1.24\end{array}$ \\
\hline $\begin{array}{l}3 B \\
3 C \\
3 E\end{array}$ & $\begin{array}{l}0912 \\
0902 \\
0906\end{array}$ & $\begin{array}{l}1233 \\
1243 \\
1251\end{array}$ & $\begin{array}{l}3.35 \\
3.68 \\
3.75\end{array}$ & & & $\begin{array}{l}0 \\
0 \\
0\end{array}$ & $\begin{array}{l}0 \\
0 \\
0\end{array}$ & $\begin{array}{l}0 \\
0 \\
0\end{array}$ & $\begin{array}{l}0 \\
0 \\
0\end{array}$ & $\begin{array}{l}0 \\
0 \\
0\end{array}$ & $\begin{array}{l}0 \\
0 \\
0\end{array}$ \\
\hline
\end{tabular}


TABLE 16. Drift Droplet Deposition Patterns for Test Run 3, 6-15-78

(see Table El.3 for detailed droplet spectra)

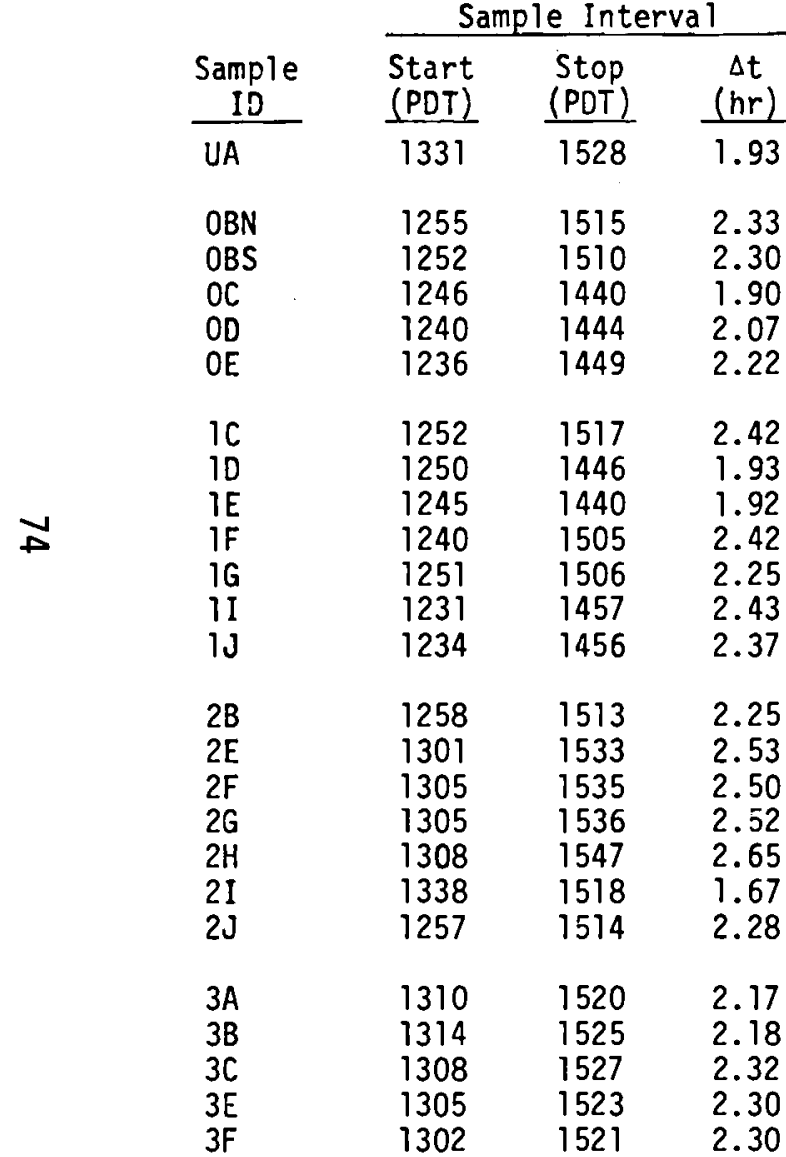

\begin{tabular}{|c|c|c|c|c|}
\hline $\begin{array}{l}\text { Area } \\
\left(m^{2}\right)\end{array}$ & Method & Number & $\begin{array}{c}\text { Mass L } \\
(\mu g)\end{array}$ & $\begin{array}{c}\text { Mass U } \\
(\mu g)\end{array}$ \\
\hline \multirow[t]{2}{*}{.0498} & $F$ & 1 & & 56 \\
\hline & & $\begin{array}{l}0 \\
0\end{array}$ & $\begin{array}{l}0 \\
0\end{array}$ & $\begin{array}{l}0 \\
0\end{array}$ \\
\hline \multirow[t]{2}{*}{$\begin{array}{l}.0504 \\
.0488\end{array}$} & $\begin{array}{l}F \\
F\end{array}$ & $\begin{array}{c}200 \\
504 \\
0\end{array}$ & $\begin{array}{c}9550 \\
12900 \\
0\end{array}$ & $\begin{array}{c}20000 \\
21900 \\
0\end{array}$ \\
\hline & & 0 & 0 & 0 \\
\hline .0481 & $F$ & 179 & 6940 & 14100 \\
\hline .0488 & $\mathrm{~F}$ & $\begin{array}{c}108 \\
0\end{array}$ & $\begin{array}{c}2870 \\
0\end{array}$ & $\begin{array}{c}5070 \\
0\end{array}$ \\
\hline \multirow{6}{*}{$\begin{array}{l}.0484 \\
.0471 \\
.0481\end{array}$} & $\begin{array}{l}F \\
F\end{array}$ & $\begin{array}{l}17 \\
23\end{array}$ & $\begin{array}{l}440 \\
770\end{array}$ & $\begin{array}{l}722 \\
1430\end{array}$ \\
\hline & $F$ & 5 & 170 & 260 \\
\hline & & 0 & 0 & 0 \\
\hline & & 0 & 0 & 0 \\
\hline & & 0 & 0 & 0 \\
\hline & & 0 & 0 & 0 \\
\hline \multirow[t]{8}{*}{.0476} & $F$ & 7 & 370 & 660 \\
\hline & & 0 & 0 & 0 \\
\hline & & 0 & 0 & 0 \\
\hline & & 0 & 0 & 0 \\
\hline & & 0 & 0 & 0 \\
\hline & & 0 & 0 & 0 \\
\hline & & 0 & 0 & 0 \\
\hline & & 0 & 0 & 0 \\
\hline
\end{tabular}

\begin{tabular}{|c|c|c|}
\hline $\begin{array}{c}\text { Number } \\
\left(\mathrm{m}^{-2} \cdot \mathrm{hr}^{-1}\right) \\
\end{array}$ & $\begin{array}{l}\text { Mass } L \\
\left(m g \cdot m^{-2}\right.\end{array}$ & $\begin{array}{c}\text { Mass U } \\
\left.h r^{-1}\right)\end{array}$ \\
\hline 10 & & 0.6 \\
\hline $\begin{array}{c}0 \\
0 \\
2090 \\
4990 \\
0\end{array}$ & $\begin{array}{c}0 \\
0 \\
100 \\
128 \\
0\end{array}$ & $\begin{array}{c}0 \\
0 \\
210 \\
217 \\
0\end{array}$ \\
\hline $\begin{array}{c}0 \\
1930 \\
1150 \\
0 \\
155 \\
201 \\
44\end{array}$ & $\begin{array}{c}0 \\
75 \\
31 \\
0 \\
4.0 \\
6.7 \\
1.5\end{array}$ & $\begin{array}{c}0 \\
152 \\
54 \\
0 \\
6.6 \\
12.5 \\
2.3\end{array}$ \\
\hline $\begin{array}{c}0 \\
0 \\
0 \\
0 \\
55 \\
0 \\
0\end{array}$ & $\begin{array}{c}0 \\
0 \\
0 \\
0 \\
2.9 \\
0 \\
0\end{array}$ & $\begin{array}{c}0 \\
0 \\
0 \\
0 \\
5.2 \\
0 \\
0\end{array}$ \\
\hline $\begin{array}{l}0 \\
0 \\
0 \\
0 \\
0\end{array}$ & $\begin{array}{l}0 \\
0 \\
0 \\
0 \\
0\end{array}$ & $\begin{array}{l}0 \\
0 \\
0 \\
0 \\
0\end{array}$ \\
\hline
\end{tabular}


TABLE 17. Drift Droplet Deposition Patterns for Test Run 4, 6-21-78 (see Table El.4 for detailed droplet spectra)

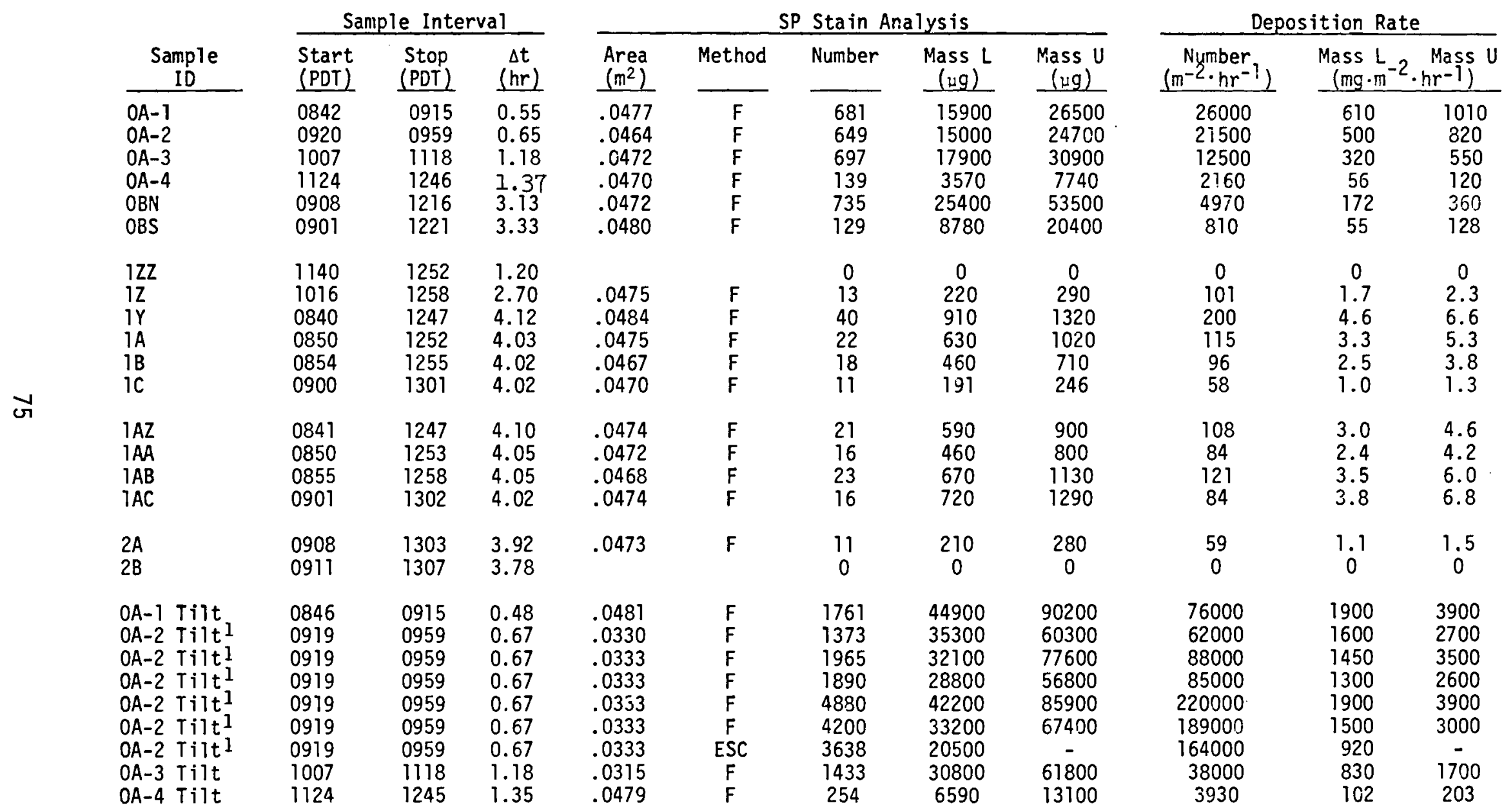

${ }^{1}$ See text and Table El.4 for discussion of these values. 
TABLE 18. Drift Oroplet Deposition Patterns for Test Run 5, 6-18-78 (see Table El.5 for detailed droplet spectra)

\begin{tabular}{|c|c|c|c|c|c|c|c|c|c|c|c|}
\hline \multirow[b]{2}{*}{ Sample } & \multicolumn{3}{|c|}{ Sample Inte } & \multicolumn{5}{|c|}{ tain Analysis } & \multicolumn{3}{|c|}{ Deposition Rate } \\
\hline & $\begin{array}{l}\text { Start } \\
\text { (PDT) }\end{array}$ & $\begin{array}{c}\text { Stop } \\
\text { (PDT) }\end{array}$ & $\begin{array}{c}\Delta t \\
(h r) \\
\end{array}$ & $\begin{array}{l}\text { Area } \\
\left(\mathrm{m}^{2}\right) \\
\end{array}$ & Method & Number & $\begin{array}{c}\text { Mass L } \\
(\mathrm{Hg})\end{array}$ & $\begin{array}{l}\text { Mass U } \\
(\mu g)\end{array}$ & $\begin{array}{c}\text { Number } \\
\left(\mathrm{m}^{-2} \cdot \mathrm{hr}^{-1}\right)\end{array}$ & $\begin{array}{r}\text { Mass L } \\
(\mathrm{mg} \cdot \mathrm{m} \\
\end{array}$ & $\begin{array}{l}\text { Mass U } \\
\left.a r^{-1}\right)\end{array}$ \\
\hline $\begin{array}{l}O A \\
O C\end{array}$ & $\begin{array}{l}0819 \\
0813\end{array}$ & $\begin{array}{l}1223 \\
1215\end{array}$ & $\begin{array}{l}4.07 \\
4.03\end{array}$ & & & $\begin{array}{l}0 \\
0\end{array}$ & $\begin{array}{l}0 \\
0\end{array}$ & $\begin{array}{l}0 \\
0\end{array}$ & $\begin{array}{l}0 \\
0\end{array}$ & $\begin{array}{l}0 \\
0\end{array}$ & $\begin{array}{l}0 \\
0\end{array}$ \\
\hline $\begin{array}{l}1 Z \\
1 Y-1 \\
1 Y-2 \\
1 A-1 \\
1 A-2 \\
1 A-3 \\
1 B-1 \\
1 B-2 \\
1 B-3 \\
1 C\end{array}$ & $\begin{array}{l}0846 \\
0845 \\
1043 \\
0837 \\
1015 \\
1128 \\
0900 \\
1009 \\
1122 \\
1000\end{array}$ & $\begin{array}{l}1229 \\
1039 \\
1214 \\
1012 \\
1128 \\
1208 \\
1007 \\
1121 \\
1216 \\
1208\end{array}$ & $\begin{array}{l}3.72 \\
1.90 \\
1.52 \\
1.58 \\
1.22 \\
0.67 \\
1.12 \\
1.20 \\
0.90 \\
2.13\end{array}$ & $\begin{array}{l}.0465 \\
.0460 \\
.0456 \\
.0469 \\
.0451 \\
.0454 \\
.0456 \\
.0467 \\
.0459 \\
.0459\end{array}$ & $\begin{array}{l}F \\
F \\
F \\
F \\
F \\
F \\
F \\
F \\
F \\
F\end{array}$ & $\begin{array}{c}9 \\
367 \\
59 \\
477 \\
418 \\
150 \\
715 \\
477 \\
353 \\
176\end{array}$ & $\begin{array}{c}120 \\
13400 \\
1280 \\
18300 \\
17800 \\
4580 \\
26500 \\
17200 \\
13000 \\
6780\end{array}$ & $\begin{array}{c}159 \\
29200 \\
1920 \\
37100 \\
37700 \\
9230 \\
55600 \\
33100 \\
34300 \\
15100\end{array}$ & $\begin{array}{c}52 \\
4200 \\
850 \\
6400 \\
7600 \\
4950 \\
14000 \\
8500 \\
8500 \\
1800\end{array}$ & $\begin{array}{c}0.69 \\
153 \\
18 \\
250 \\
320 \\
151 \\
520 \\
310 \\
310 \\
69\end{array}$ & $\begin{array}{c}0.92 \\
334 \\
28 \\
500 \\
690 \\
305 \\
1090 \\
590 \\
830 \\
154\end{array}$ \\
\hline $\begin{array}{l}\text { IAZ } \\
\text { IAA-1 } \\
\text { IAA-2 } \\
\text { IAB }\end{array}$ & $\begin{array}{l}0831 \\
0837 \\
1033 \\
0928\end{array}$ & $\begin{array}{l}1219 \\
1031 \\
1222 \\
1202\end{array}$ & $\begin{array}{l}3.80 \\
1.90 \\
1.82 \\
2.57\end{array}$ & $\begin{array}{l}.0463 \\
.0461 \\
.0454 \\
.0464\end{array}$ & $\begin{array}{l}F \\
F \\
F \\
F\end{array}$ & $\begin{array}{l}70 \\
643 \\
160 \\
209\end{array}$ & $\begin{array}{r}2160 \\
32700 \\
5270 \\
12100\end{array}$ & $\begin{array}{c}4040 \\
71100 \\
10300 \\
27800\end{array}$ & $\begin{array}{l}400 \\
7300 \\
1940 \\
1750\end{array}$ & $\begin{array}{c}12 \\
370 \\
64 \\
101\end{array}$ & $\begin{array}{l}23 \\
810 \\
125 \\
233\end{array}$ \\
\hline $\begin{array}{l}2 A \\
2 B\end{array}$ & $\begin{array}{l}0829 \\
0834\end{array}$ & $\begin{array}{l}1225 \\
1229\end{array}$ & $\begin{array}{l}3.93 \\
3.92\end{array}$ & $\begin{array}{l}.0458 \\
.0461\end{array}$ & $\begin{array}{l}F \\
F\end{array}$ & $\begin{array}{r}98 \\
230\end{array}$ & $\begin{array}{l}2780 \\
7010\end{array}$ & $\begin{array}{c}4930 \\
16000\end{array}$ & $\begin{array}{c}540 \\
1270\end{array}$ & $\begin{array}{l}15 \\
39\end{array}$ & $\begin{array}{l}27 \\
89\end{array}$ \\
\hline
\end{tabular}


TABLE 19. Drift Droplet Deposition Patterns for Test Run 6, 6-22-78

(see Table El.6 for detailed droplet spectra)

\begin{tabular}{|c|c|c|c|c|c|c|c|c|c|c|c|}
\hline $\begin{array}{c}\text { Sample } \\
\text { ID }\end{array}$ & \multicolumn{3}{|c|}{ Sample Interval } & \multicolumn{5}{|c|}{ SP Stain Analysis } & \multicolumn{3}{|c|}{ Deposition Rate } \\
\hline $\begin{array}{l}O A-1 \\
O A-2 \\
O A-3 \\
O A-4 \\
O B N-1 \\
O B N-2 \\
O B N-3 \\
O B S\end{array}$ & $\begin{array}{l}0820 \\
0859 \\
1001 \\
1057 \\
0808 \\
0950 \\
1047 \\
0803\end{array}$ & $\begin{array}{l}0853 \\
0955 \\
1052 \\
1146 \\
0946 \\
1045 \\
1154 \\
1159\end{array}$ & $\begin{array}{l}0.55 \\
0.93 \\
0.85 \\
0.82 \\
1.63 \\
0.92 \\
1.12 \\
3.93\end{array}$ & $\begin{array}{l}.0464 \\
.0466 \\
.0457 \\
.0463 \\
.0456 \\
.0462 \\
.0451 \\
.0468\end{array}$ & $\begin{array}{l}F \\
F \\
F \\
F \\
F \\
F \\
F \\
F\end{array}$ & $\begin{array}{c}637 \\
1148 \\
767 \\
577 \\
897 \\
1064 \\
726 \\
37\end{array}$ & $\begin{array}{c}14300 \\
29900 \\
14700 \\
10100 \\
24400 \\
37200 \\
21900 \\
520\end{array}$ & $\begin{array}{c}25400 \\
58100 \\
25900 \\
16700 \\
48300 \\
80900 \\
43100 \\
760\end{array}$ & $\begin{array}{c}25000 \\
26400 \\
19700 \\
15300 \\
12000 \\
25100 \\
14400 \\
201\end{array}$ & $\begin{array}{l}560 \\
690 \\
380 \\
270 \\
330 \\
880 \\
430 \\
2.8\end{array}$ & $\begin{array}{c}1000 \\
1340 \\
670 \\
440 \\
650 \\
1910 \\
850 \\
4.1\end{array}$ \\
\hline $\begin{array}{l}2 A \\
2 B\end{array}$ & $\begin{array}{l}0819 \\
0824\end{array}$ & $\begin{array}{l}1205 \\
1209\end{array}$ & $\begin{array}{l}3.77 \\
3.75\end{array}$ & $\begin{array}{l}.0456 \\
.0458\end{array}$ & $\begin{array}{l}F \\
F\end{array}$ & $\begin{array}{l}134 \\
331\end{array}$ & $\begin{array}{c}2870 \\
10600\end{array}$ & $\begin{array}{c}4950 \\
22100\end{array}$ & $\begin{array}{c}780 \\
1930\end{array}$ & $\begin{array}{l}17 \\
62\end{array}$ & $\begin{array}{c}29 \\
129\end{array}$ \\
\hline $\begin{array}{l}O A-1 \text { Tilt } \\
O A-2 \text { Tilt } \\
O A-3 \text { Tilt } \\
O A-4 \text { Tilt }\end{array}$ & $\begin{array}{l}0820 \\
0859 \\
1001 \\
1057\end{array}$ & $\begin{array}{l}0853 \\
0955 \\
1052 \\
1146\end{array}$ & $\begin{array}{l}0.55 \\
0.93 \\
0.85 \\
0.82\end{array}$ & $\begin{array}{l}.0333 \\
.0166 \\
.0342 \\
.0232\end{array}$ & $\begin{array}{l}F \\
F \\
F \\
F\end{array}$ & $\begin{array}{c}1333 \\
991 \\
1380 \\
1077\end{array}$ & $\begin{array}{l}34200 \\
32100 \\
37300 \\
33700\end{array}$ & $\begin{array}{l}68100 \\
64400 \\
74500 \\
50800\end{array}$ & $\begin{array}{c}73000 \\
64000 \\
47400 \\
57000\end{array}$ & $\begin{array}{l}1870 \\
2070 \\
1280 \\
1780\end{array}$ & $\begin{array}{l}3720 \\
4160 \\
2560 \\
2680\end{array}$ \\
\hline $\begin{array}{l}\text { lA Tilt } \\
\text { lB-1 Tilt } \\
\text { lB-2 Tilt } \\
\text { lB-3 Tilt }\end{array}$ & $\begin{array}{l}0934 \\
0918 \\
1013 \\
1105\end{array}$ & $\begin{array}{l}1051 \\
1004 \\
1054 \\
1204\end{array}$ & $\begin{array}{l}1.28 \\
0.77 \\
0.68 \\
0.98\end{array}$ & $\begin{array}{l}.0226 \\
.0342 \\
.0459 \\
.0337\end{array}$ & $\begin{array}{l}F \\
F \\
F \\
F\end{array}$ & $\begin{array}{l}1067 \\
1607 \\
1091 \\
1395\end{array}$ & $\begin{array}{l}29200 \\
61800 \\
56100 \\
69900\end{array}$ & $\begin{array}{l}58500 \\
150000 \\
132000 \\
140000\end{array}$ & $\begin{array}{l}36900 \\
61000 \\
34800 \\
42100\end{array}$ & $\begin{array}{l}1010 \\
2360 \\
1790 \\
2110\end{array}$ & $\begin{array}{l}2020 \\
5720 \\
4210 \\
4230\end{array}$ \\
\hline
\end{tabular}


TABLE 20. Orift Droplet Deposition Patterns for Test Run $x, 6-25-78$ (see Table El.X for detailed droplet spectra)

\begin{tabular}{|c|c|c|c|c|c|c|c|c|c|c|c|}
\hline & \multicolumn{3}{|c|}{ Sample Interval } & \multicolumn{5}{|c|}{ SP Stain Analysis } & \multicolumn{3}{|c|}{ Deposition Rate } \\
\hline $\begin{array}{c}\text { Sample } \\
\text { ID } \\
\end{array}$ & $\begin{array}{l}\text { Start } \\
\text { (PDT) }\end{array}$ & $\begin{array}{c}\text { Stop } \\
\text { (PDT) } \\
\end{array}$ & $\begin{array}{c}\Delta t \\
(h r) \\
\end{array}$ & $\begin{array}{l}\text { Area } \\
\left(m^{2}\right\rangle \\
\end{array}$ & Method & Number & $\begin{array}{l}\text { Mass L } \\
(\mu \mathrm{g}) \\
\end{array}$ & $\begin{array}{l}\text { Mass U } \\
(\mu \mathrm{g}) \\
\end{array}$ & 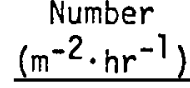 & $\begin{array}{l}\text { Mass } 1 \\
\text { (mg. }\end{array}$ & $\begin{array}{c}\text { Mass U } \\
\left.h r^{-1}\right)\end{array}$ \\
\hline $1-1-5 U$ & 0912 & 0942 & 0.50 & .0134 & $F$ & 21 & 510 & 770 & 3130 & 76 & 115 \\
\hline $\begin{array}{l}1-1-N \\
1-1-5\end{array}$ & $\begin{array}{l}0826 \\
0828\end{array}$ & $\begin{array}{l}0843 \\
0844\end{array}$ & $\begin{array}{l}0.28 \\
0.27\end{array}$ & $\begin{array}{l}.0130 \\
.0130\end{array}$ & $\begin{array}{l}F \\
F\end{array}$ & $\begin{array}{l}147 \\
129\end{array}$ & $\begin{array}{l}51000 \\
14200\end{array}$ & $\begin{array}{c}143000 \\
42400\end{array}$ & $\begin{array}{l}40500 \\
37200\end{array}$ & $\begin{array}{c}14000 \\
4100\end{array}$ & $\begin{array}{l}39000 \\
12000\end{array}$ \\
\hline $\begin{array}{l}1-2-N \\
1-2-2\end{array}$ & $\begin{array}{l}0832 \\
0830\end{array}$ & $\begin{array}{l}0839 \\
0837\end{array}$ & $\begin{array}{l}0.12 \\
0.12\end{array}$ & $\begin{array}{l}.0134 \\
.0131\end{array}$ & $\begin{array}{l}F \\
F\end{array}$ & $\begin{array}{c}89 \\
284\end{array}$ & $\begin{array}{l}60000 \\
34600\end{array}$ & $\begin{array}{c}168000 \\
88800\end{array}$ & $\begin{array}{c}55000 \\
185000\end{array}$ & $\begin{array}{l}37000 \\
23000\end{array}$ & $\begin{array}{r}104000 \\
58000\end{array}$ \\
\hline $\begin{array}{l}1-3-N \\
1-3-5\end{array}$ & $\begin{array}{l}0848 \\
0846\end{array}$ & $\begin{array}{l}0856 \\
0854.5\end{array}$ & $\begin{array}{l}0.13 \\
0.14\end{array}$ & $\begin{array}{l}.0132 \\
.0135\end{array}$ & $\begin{array}{l}F \\
F\end{array}$ & $\begin{array}{l}326 \\
231\end{array}$ & $\begin{array}{l}54400 \\
45900\end{array}$ & $\begin{array}{l}145000 \\
124000\end{array}$ & $\begin{array}{l}191000 \\
121000\end{array}$ & $\begin{array}{l}32000 \\
24000\end{array}$ & $\begin{array}{l}85000 \\
65000\end{array}$ \\
\hline $1-4-N$ & 0851 & 0859 & 0.13 & .0131 & $\mathrm{~F}$ & 188 & 48000 & 124000 & - 11000 & 28000 & 73000 \\
\hline $\begin{array}{l}1-7-N \\
1-7-S\end{array}$ & $\begin{array}{l}0904 \\
0902\end{array}$ & $\begin{array}{l}0909 \\
0906\end{array}$ & $\begin{array}{l}.083 \\
.067\end{array}$ & $\begin{array}{l}.0125 \\
.0132\end{array}$ & $\begin{array}{l}F \\
F\end{array}$ & $\begin{array}{l}82 \\
136\end{array}$ & $\begin{array}{c}223000 \\
58000\end{array}$ & $\begin{array}{c}63300 \\
161000\end{array}$ & $\begin{array}{c}79000 \\
154000\end{array}$ & $\begin{array}{l}21000 \\
66000\end{array}$ & $\begin{array}{c}61000 \\
182000\end{array}$ \\
\hline $\begin{array}{l}1-13-G \\
1-13-G S\end{array}$ & $\begin{array}{l}0914 \\
0918\end{array}$ & $\begin{array}{l}0944 \\
0942\end{array}$ & $\begin{array}{l}0.50 \\
0.40\end{array}$ & $\begin{array}{l}.0134 \\
.0131\end{array}$ & $\begin{array}{l}F \\
F\end{array}$ & $\begin{array}{l}111 \\
112\end{array}$ & $\begin{array}{l}25800 \\
38600\end{array}$ & $\begin{array}{c}46800 \\
105000\end{array}$ & $\begin{array}{l}.17000 \\
21000\end{array}$ & $\begin{array}{l}3900 \\
7400\end{array}$ & $\begin{array}{c}7000 \\
20000\end{array}$ \\
\hline
\end{tabular}




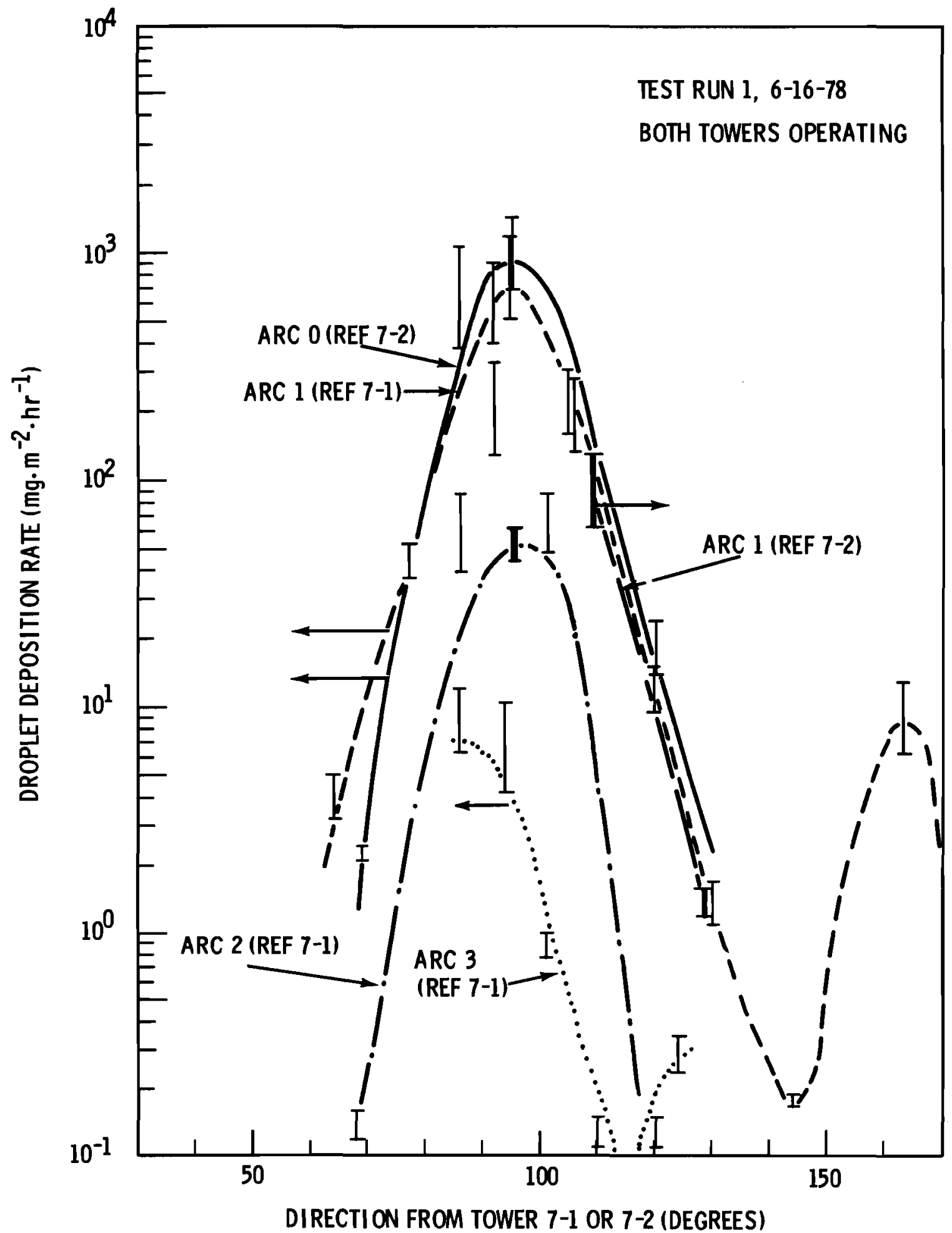

FIGURE 13. Drift Droplet Mass Deposition Pattern for Test Run 1, 6-16-78, with Both Towers Operating 


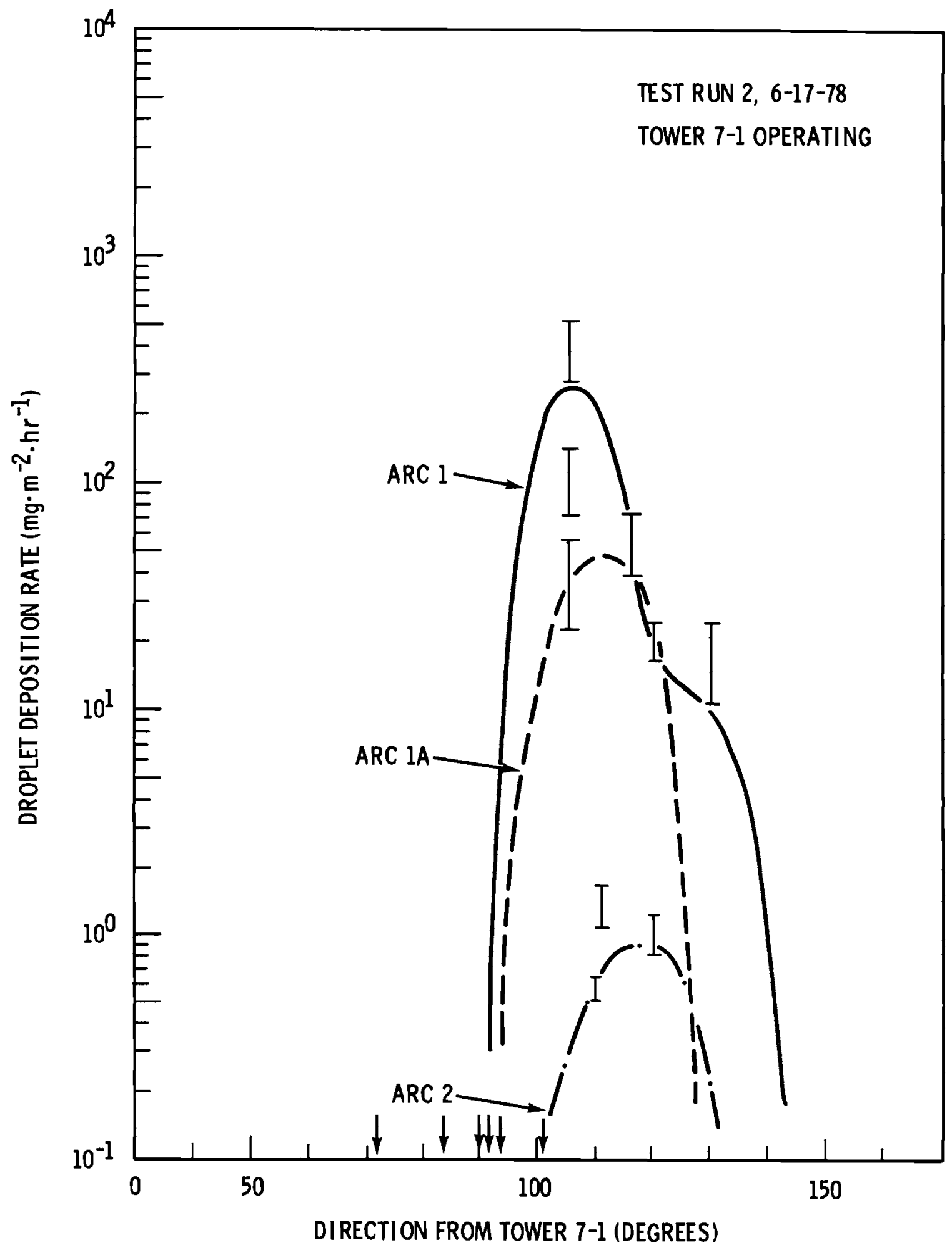

FIGURE 14. Drift Droplet Mass Deposition Pattern for Test Run 2, 6-17-78, with Tower 7-1 Operating On 1y 


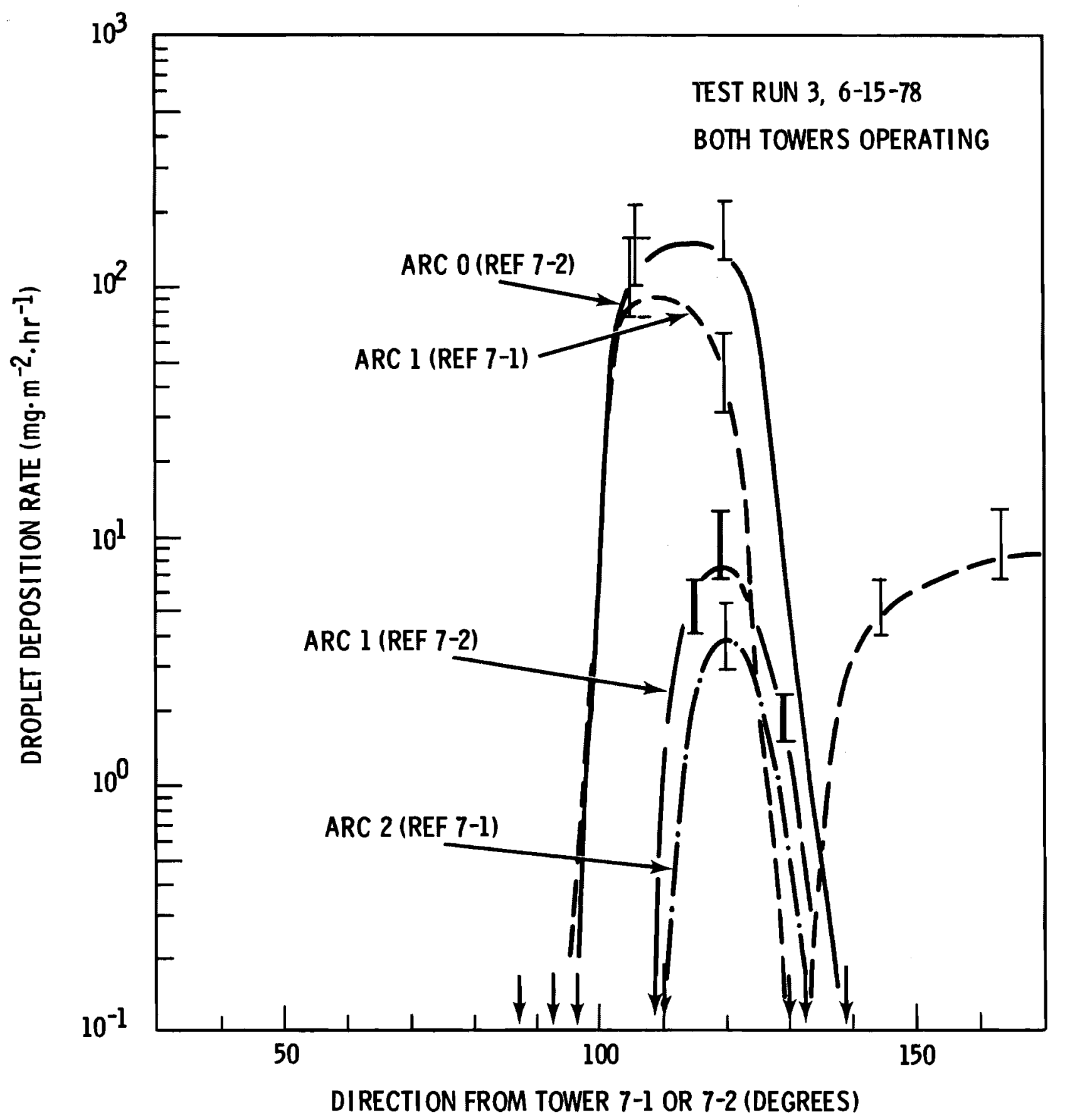

FIGURE 15. Drift Droplet Mass Deposition Pattern for Test Run 3, 6-15-78, with Both Towers Operating 


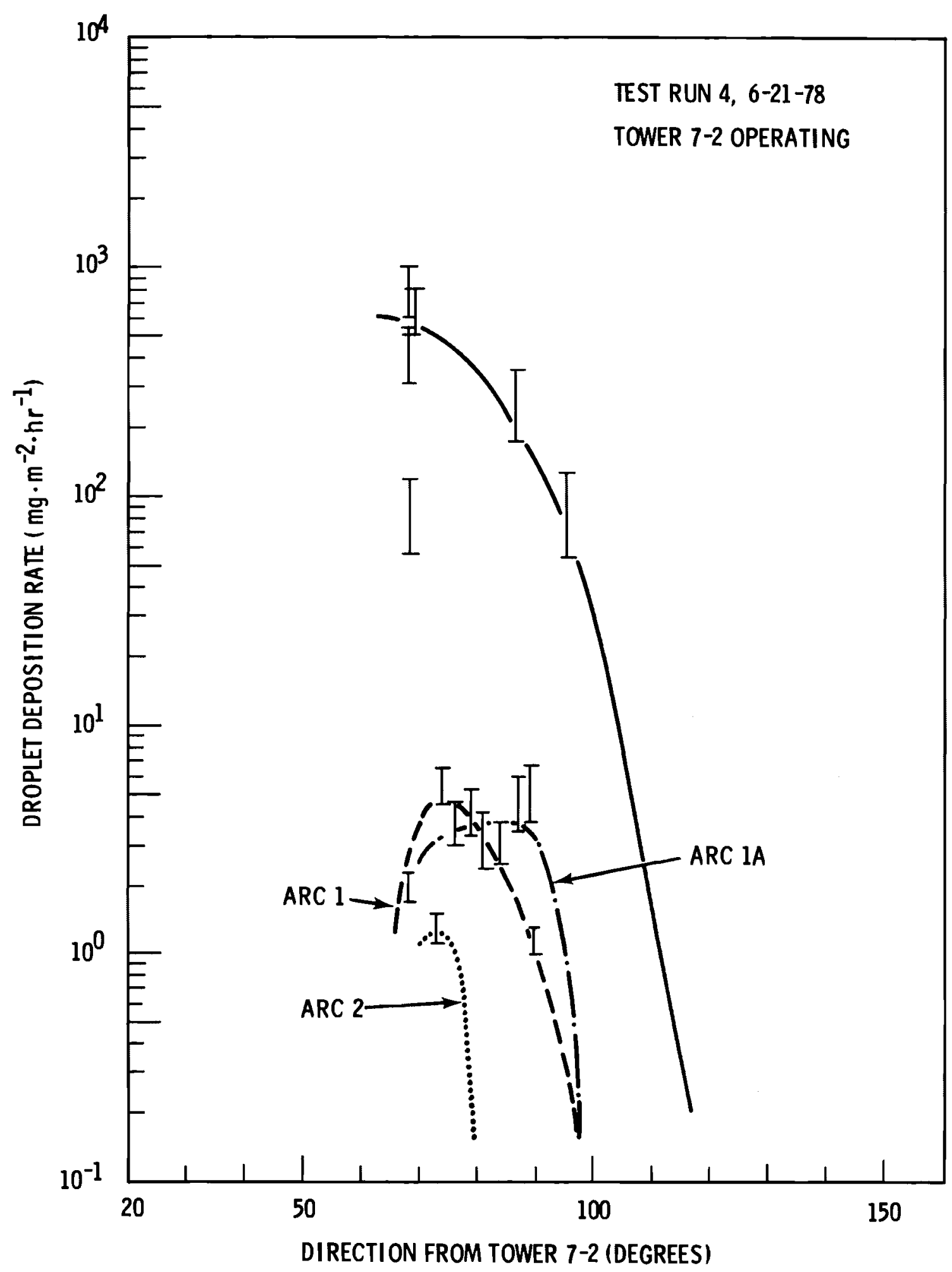

FIGURE 16. Drift Droplet Mass Deposition Pattern for Test Run 4, 6-21-78, with Tower 7-2 Operating Only 


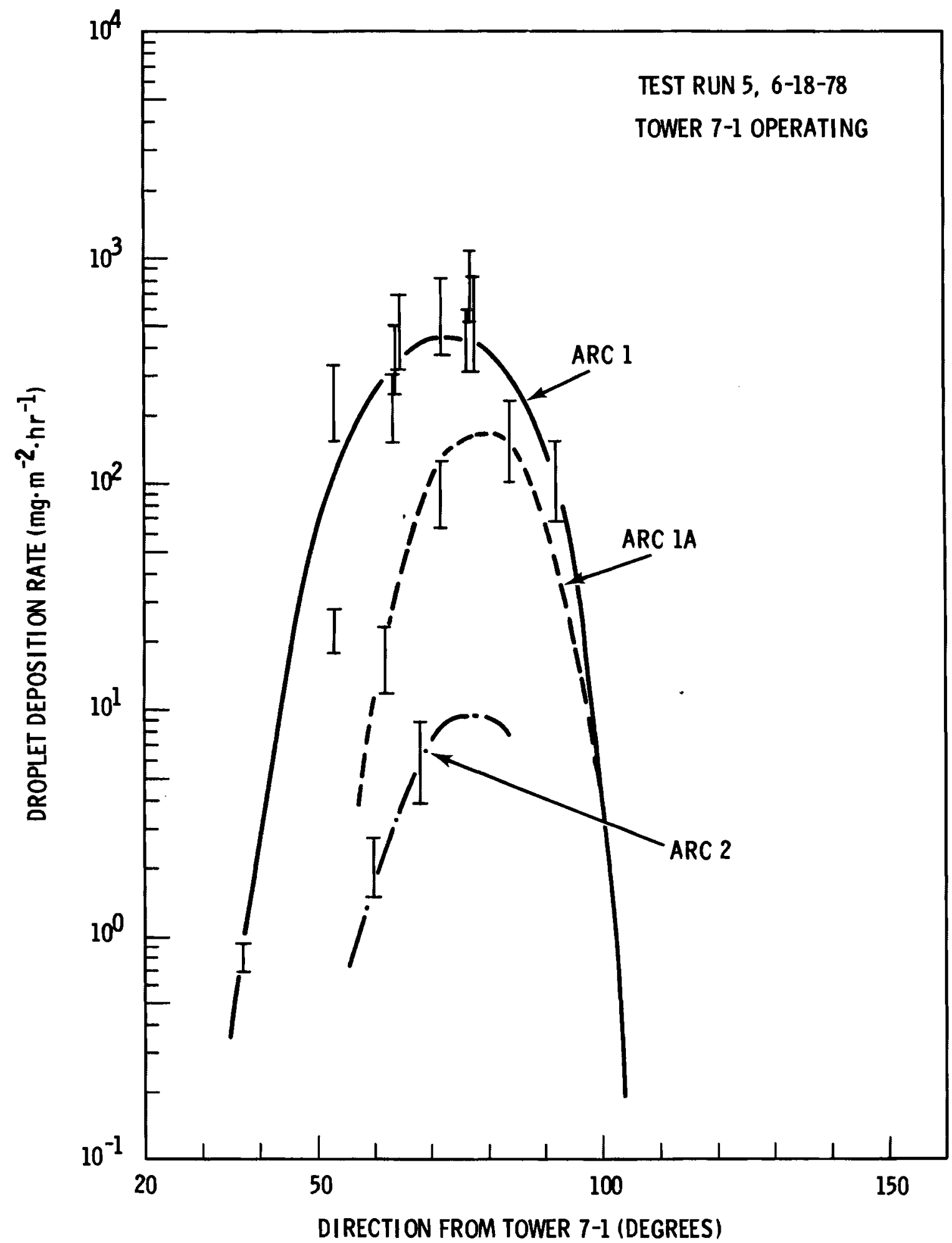

FIGURE 17. Drift Droplet Mass Deposition Pattern for Test Run 5, 6-18-78, with Tower 7-1 Operating Only 


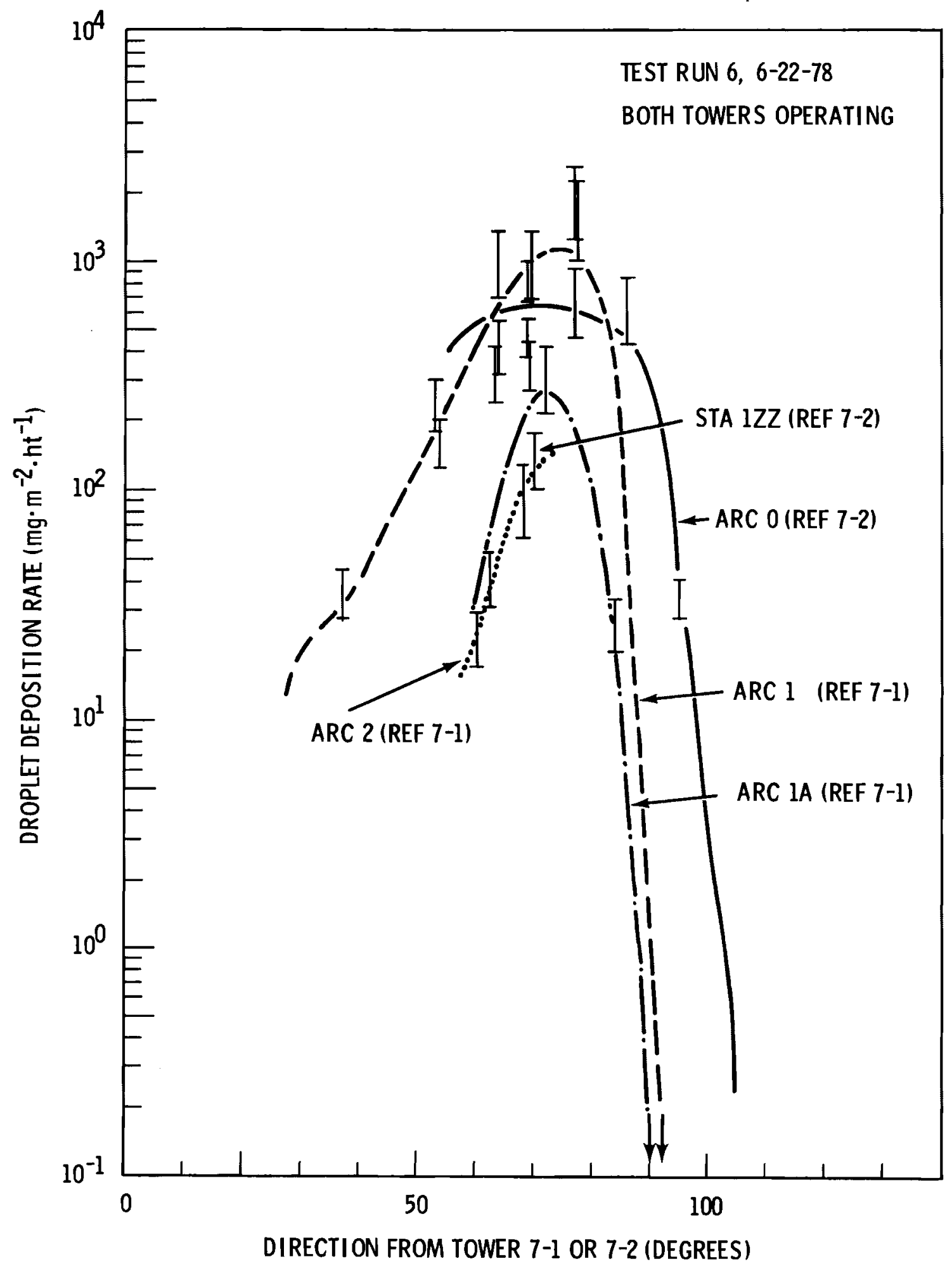

FIGURE 18. Drift Droplet Mass Deposition Pattern for Test Run 6, 6-22-78, with Both Towers Operating 


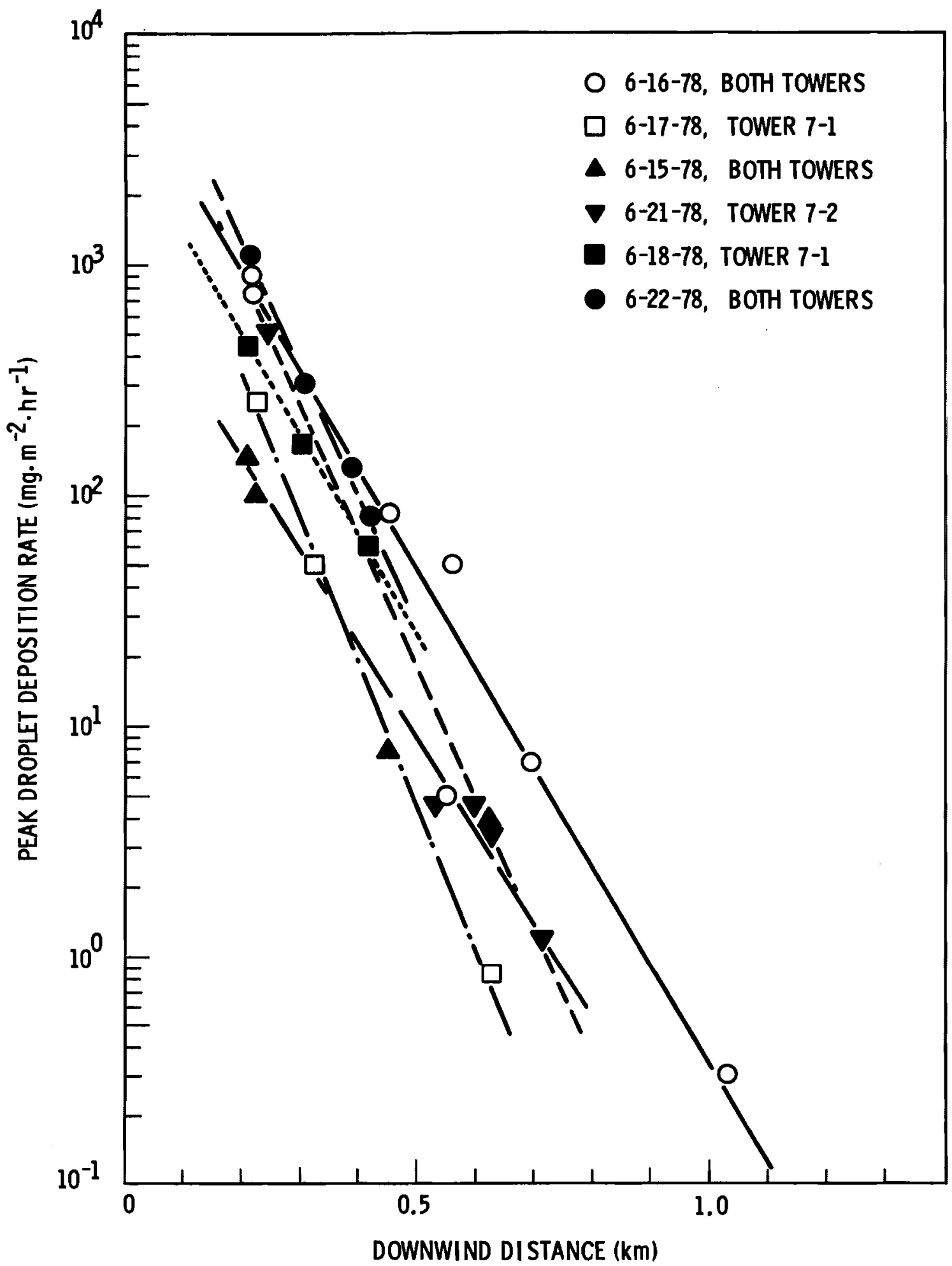

FIGURE 19. Peak Drift Droplet Mass Deposition Rate as a Function of Downwind Distance for Test Runs 1-6 


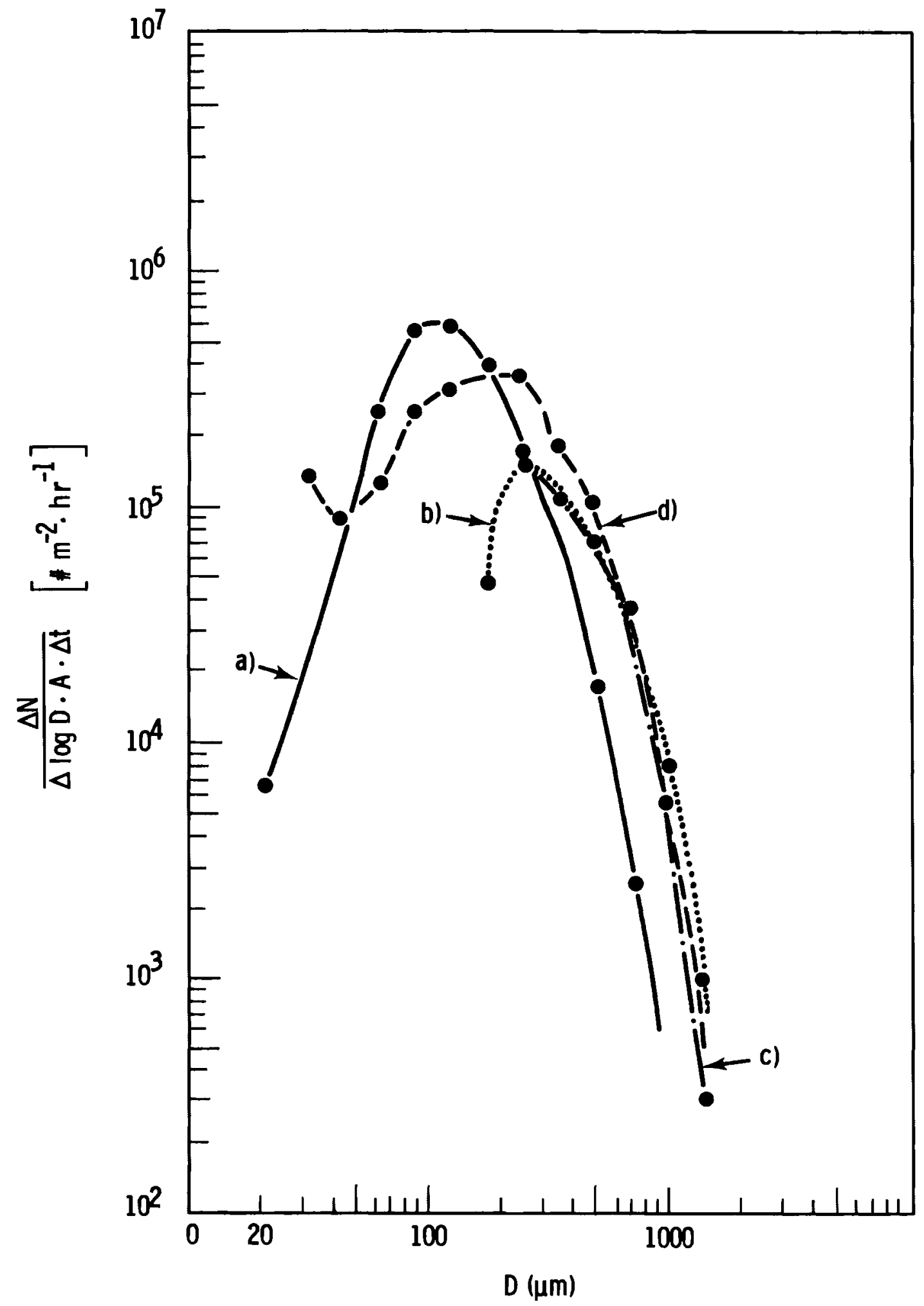

FIGURE 20. Comparison of Drift Droplet Size Spectra Obtained by Various Interrogations of SP Sample OA-2 (Tilt), 6-21-78. Curves a-d are discussed in the Text 
- the ESC spectrum covers a larger size range, $20-1000 \mu \mathrm{m}$ than the PNL spectrum, 150-1500 $\mu \mathrm{m}$;

- droplet count at the low end $(2200 \mu \mathrm{m})$ of the PNL spectrum is lower than the ESC values;

- although the shape of the curves are similar for diameter $\because 300 \mu \mathrm{m}$, the PNL curve is shifted to larger diameters by a factor of 1.5, which would result in a grossly larger estimate of droplet mass.

The PNL interrogation of 10-22-78 was corrected to the ESC calibration curve (see Fig. 8 for terminal droplet settling velocity at normal incidence). The results of this correction are shown as curve $c$ which is nearly indistinguishable from curve $b$.

Results of the reanalys is of this same SP by PNL (4-10-79) over the size range, 50-1500 $\mu \mathrm{m}$ are shown as curve d. It is seen that the droplet counts were increased considerably below $400 \mu \mathrm{m}$ with the extended range when compared to the earlier result (curve b). (The Quantimet operator noted that stain contrast had improved considerably between the October 1978 and April 1979 interrogations so that the smaller stains were easier to read.) The offset between the ESC and PNL curves by a factor of $\sim 1.5$ still exists, even though the number and the curve shape are more compatible. The reason for this difference does not appear to be related to differences in calibration curves but rather measurement procedure.

Since the ESC analysis method (1ight pen/minicomputer) differs considerably from the PNL chord width method (Quantimet/Feret), the differences are most likely the result of differences in measurement of the streak or stain widths. This condition also suggests that the directional distribution of stain axes on the SPS, which could not be accommodated by the automated PNL system, resulted in droplet spectra that were shifted towards larger droplets. 
Short of a costly reanalysis of all of the SPs, it was decided to adjust the results of the interrogations and to interpret the original PNL measured spectra using the Meyer calibration as an upper bound on the droplet mass (mass $U$ in Tables 14-20) and the adjusted spectra as a lower bound (mass $L$ in Tables 14-20). The adjustment consisted of recomputing the stain size from the Meyer calibration, reducing the stain size by a factor which would bring curves a and $d$ of $F i g .20$ into congruence (this same factor was used throughout) and to use the calibration curve (Fig. 9) appropriate for the wind speed conditions encountered during a given test. The calibration curve is approximated by

$$
D_{d}=A \quad D_{S}^{b},
$$

where

$$
\begin{aligned}
D_{d} & =\text { true droplet diameter } \\
D_{S} & =\text { measured stain diameter or width } \\
A, b & =\text { empirical constants to fit the data. }
\end{aligned}
$$

The empirical constants are found from Fig. 21 for the appropriate wind speed (see Appendix $C$ for additional discussion). With these comments in mind, the individual test runs can be discussed.

Test Run 1, 6-16-78 (Fig. 13, Table 14). Both towers were operating during this run. Arcs $0,1,2$ and 3 were set up for sampling. The drift plume centerline appeared to 1 ie between $90^{\circ}$ and $100^{\circ}$ (recall that $0^{\circ}$ is North). In Fig. 13, arc 0 is referenced to Tower 7-2 while the other arcs are referenced to Tower 7-1. The curve for arc 1 shows, in addition to the main peak at $95^{\circ}$, a smaller peak at $\sim 160^{\circ}$. If this portion of the arc 1 curve is referenced instead to Tower $7-2$, the peak shifts over to 110$120^{\circ}$. This result is also shown in Fig. 13 on the same vertical scale as for arc 2. It is apparent that this peak is the result of contributions from Tower 7-2. 


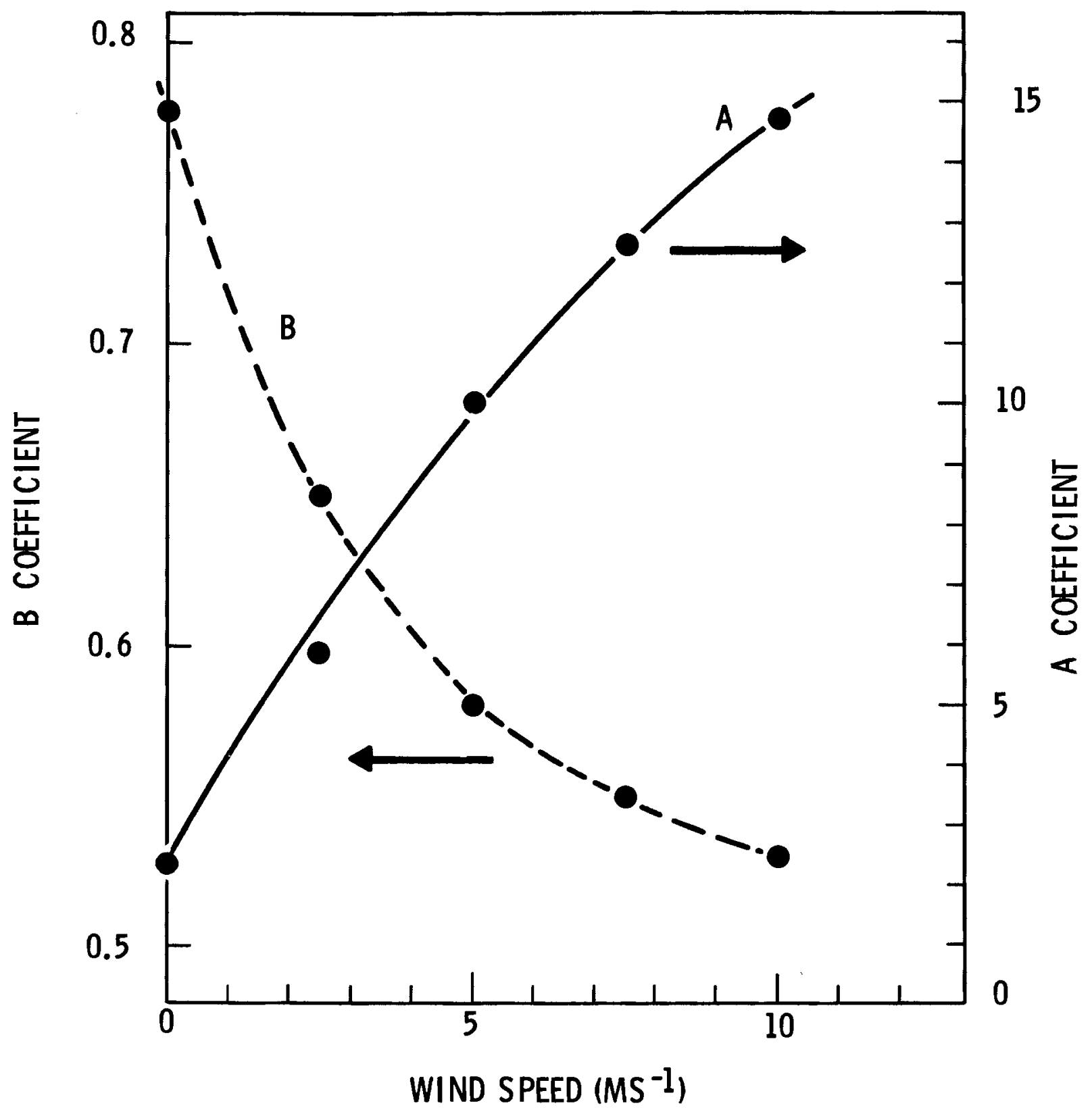

FIGURE 21. Empirical Constants $a$ and $b$ for the Calibration Equation $D_{d}=A D_{s}{ }$ as a Function of Wind Speed 
Test Run 2, 6-17-78 (Fig. 14, Table 15). Only Tower 7-1 was operating. The drift plume centerl ine appeared to be $110^{\circ}$, in agreement with winds from the WNW. Arc $1 A$ was installed in time for this test run in order to define drift entering the electrical switch yard area. No droplets were observed at arc 3 .

Test Run 3, 6-15-78 (Fig. 15, Table 16). Chronologically this was the first test run and was the only afternoon test. During this run, both towers were operating. The mineral mass deposition collections were of poor quality but the droplet data showed a distinct separation between Towers 7-1 and 7-2, especially for arc 1. As above for test run 1, when arc 1 is referenced to Tower 7-1, a smaller second peak appears at $\sim 160^{\circ}$, which shifts to $\sim 120^{\circ}$ when referenced to Tower 7-2. With winds out of $300^{\circ}$, the expected centerline should be around $120^{\circ}$, which is observed.

Test Run 4, 6-21-78 (Fig. 16, Table 17). With only Tower 7-2 operating and the winds from the 245 direction, the drift plume was observed out to $3 / 4$ $\mathrm{km}$ with very few structural interferences.

Test Run 5, 6-18-78 (Fig. 17, Table 18). Again only single tower operation (7-1) with relatively high winds $\left(\sim 7 \mathrm{~ms}^{-1}\right)$ at $\sim 245^{\circ}$.

Test Run 6, 6-22-78 (Fig. 18, Table 19). Both towers were operating with winds at $\sim 6 \mathrm{~ms}^{-1}$ from the 250 direction. Contributions from Tower 7-2 are barely apparent on the arc 1 curve near $40^{\circ}$ (referenced to Tower 7-1).

Test Run $x, 6-25-78$ (Fig. 19, Table 20). The sampling positions for this near tower test (mostly on the fan deck) are shown in Fig. 22. No mineral mass deposition data has been analyzed for this run. Winds were at 5.4 $\mathrm{ms}^{-1}$ from the $270 \pm 10^{\circ}$ direction while the temperature averaged $15.6 \pm$ $1 \mathrm{C}$ with an relative humidity of $66 \pm 4 \%$ during the test run.

The peak droplet mass deposition values in Fig. 19 for each test run as a function of downwind show remarkable similarities as well as differences. The slopes of the lines are roughly the same when both towers are operating and decrease exponentially at vexp(-10x), where $x$ is the downwind distance. For single-tower operation the slopes are again similar 


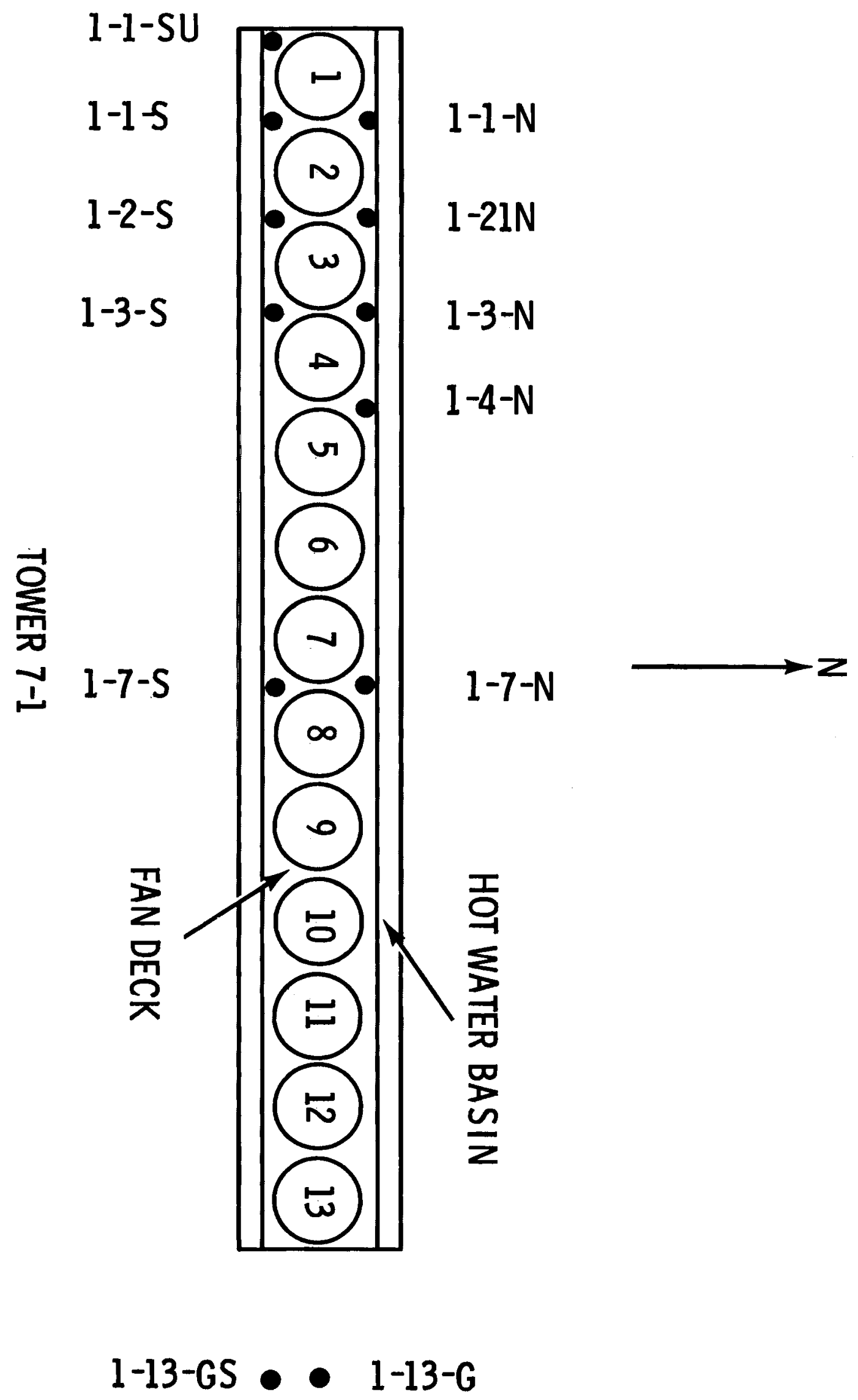

FIGURE 22. Sampling Geometry for the Near Tower Drift Test, Test Run X, 6-25-78, Tower 7-7. The Dots (•)

Show the Sampling Locations; the Numbers Identify

Them 
but larger than the two-tower value, decreasing exponentially at vexp(-15x). In the cases where both towers were operating, it was also possible to infer values from Twoer 7-2, as discussed above; these values are also included in Fig. 19.

Deposition values at $.2 \mathrm{~km}$ are nearly a factor of 10 larger for test run 1 than for test run 3. Mean temperatures, relative humidities and wind speeds were 18.4 and $23.6^{\circ} \mathrm{C}, 55$ and $43 \%$, and 4.8 and $6.6 \mathrm{~m} \mathrm{~s}^{-1}$, respectively during runs 1 and 3. Plant loads were 680 and 520 MWe, respectively, during the tests. Modeling studies would be required to discern which of these factors played a dominant role in the downwind drift deposition. Deposition values for the other test runs were found between these two extremes.

\section{Mineral Ion Deposition Patterns}

The results of chemical analysis of the bulk deposition samples for test runs 1-6 are shown in Figs, 23-28 for $\mathrm{Na}^{+}$ion. Detailed 1 isting of the mineral ion deposition rates are found in Appendix E, Tables E2.1-E2.6, for the ions $\mathrm{SO}_{4}^{--}, \mathrm{NO}_{3}^{-}, \mathrm{Cl}^{-}, \mathrm{Na}^{+}, \mathrm{K}^{+}, \mathrm{Ca}^{++}$and $\mathrm{Mg}^{++}$. Peak sodium drift mass deposition rates for each test run are shown in Figs. 29-31 as a function of downwind distance. (The conversion factor, $1 \mu \mathrm{g} \cdot \mathrm{m}^{-2} \cdot \mathrm{hr}^{-1}=$ $0.72 \mathrm{~kg} \cdot \mathrm{km}^{-2} \cdot \mathrm{mo}^{-1}$, was used for the ordinate in Figs. 29-31.) The results for the test runs are grouped according to single or double tower operation.

Inspection of Figs. 23-31 and Tables E2.1-E2.6 for the mineral mass data in comparison to Figs. 13-19 for the droplet data shows that the mineral mass deposition was much more irregular and variable than the droplet deposition. This variability is mainly due to background deposition and sample contamination arising from a variety of sources. Since the droplets are detected by the SPs by virtue of their water content, only particles that contain water produce an image; these presumably must originate from the cooling towers. (Only a few examples of droplets arriving from sources other than the cooling towers were observed -- once from the spray canal and once from Suisun Bay.) Dry particles, drift or otherwise, produce no stain on the SPS. 

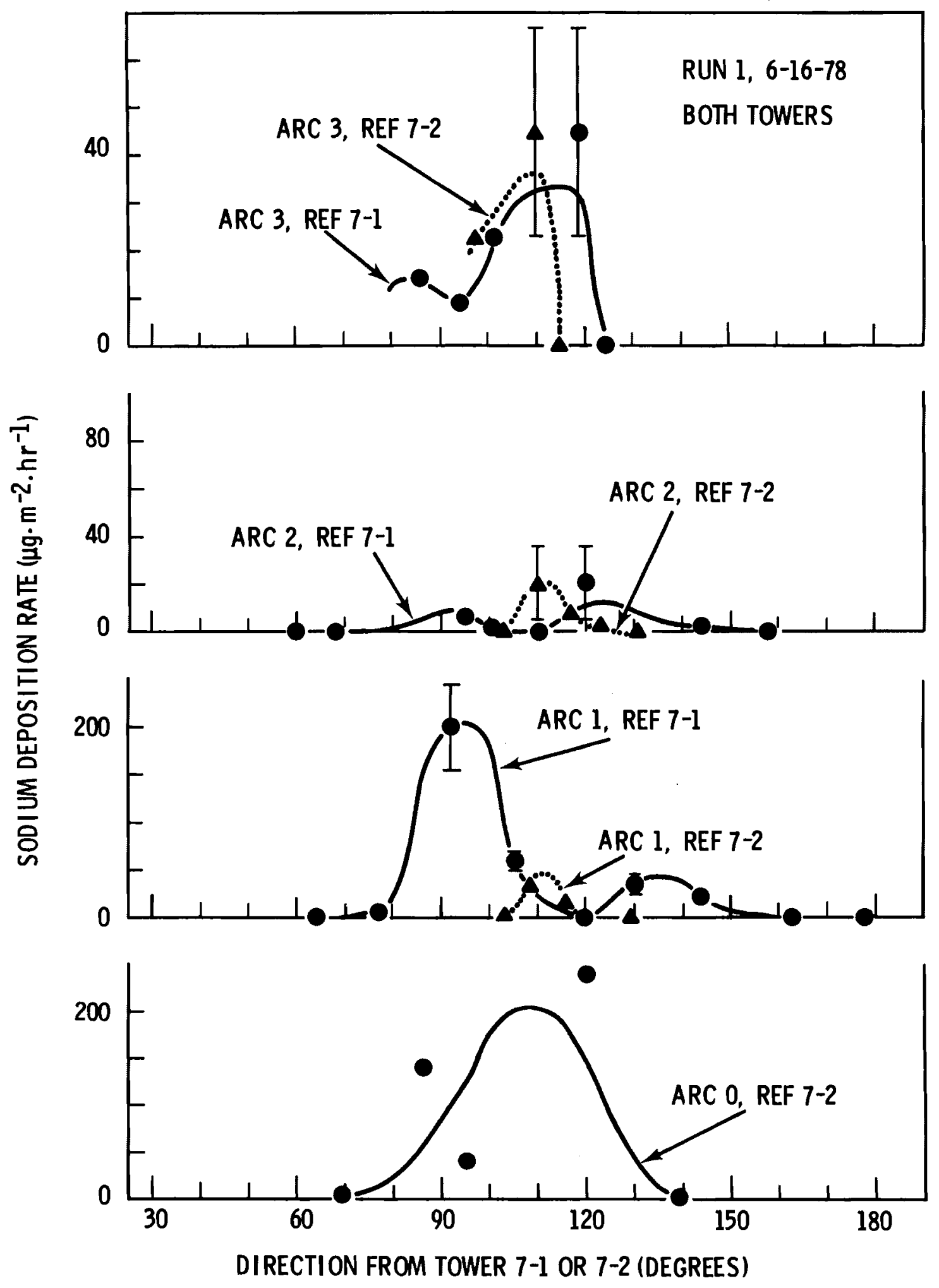

FIGURE 23. Sodium Drift Mass Deposition Pattern for Test Run 1 , 6-16-78, with Both Towers Operating 


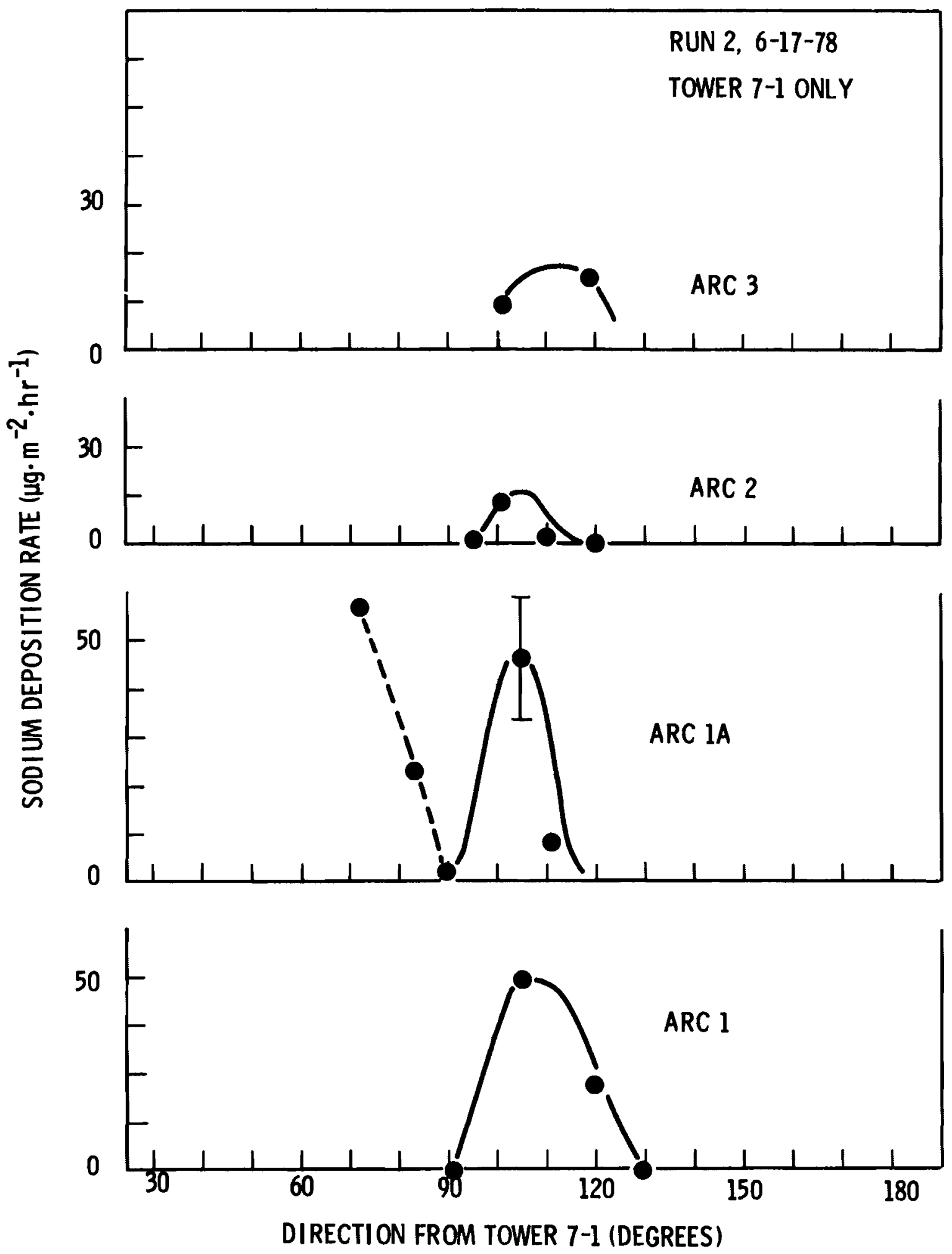

FIGURE 24. Sodium Drift Mass Deposition Pattern for Test Run 2, 6-17-78, with Tower 7-1 Operating Only 

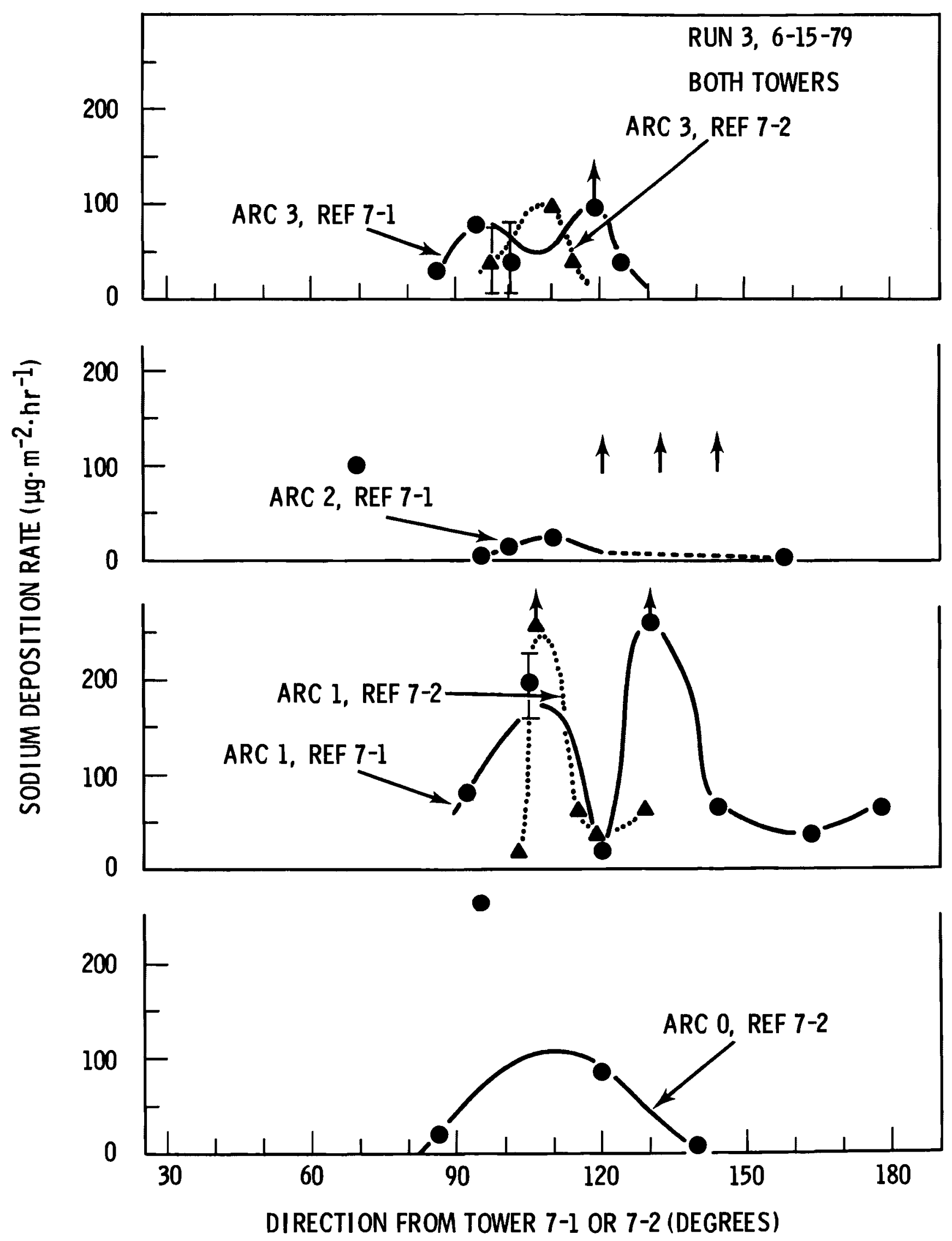

FIGURE 25. Sodium Drift Mass Deposition Pattern for Test Run 3, 6-15-78, with Both Towers Operating 


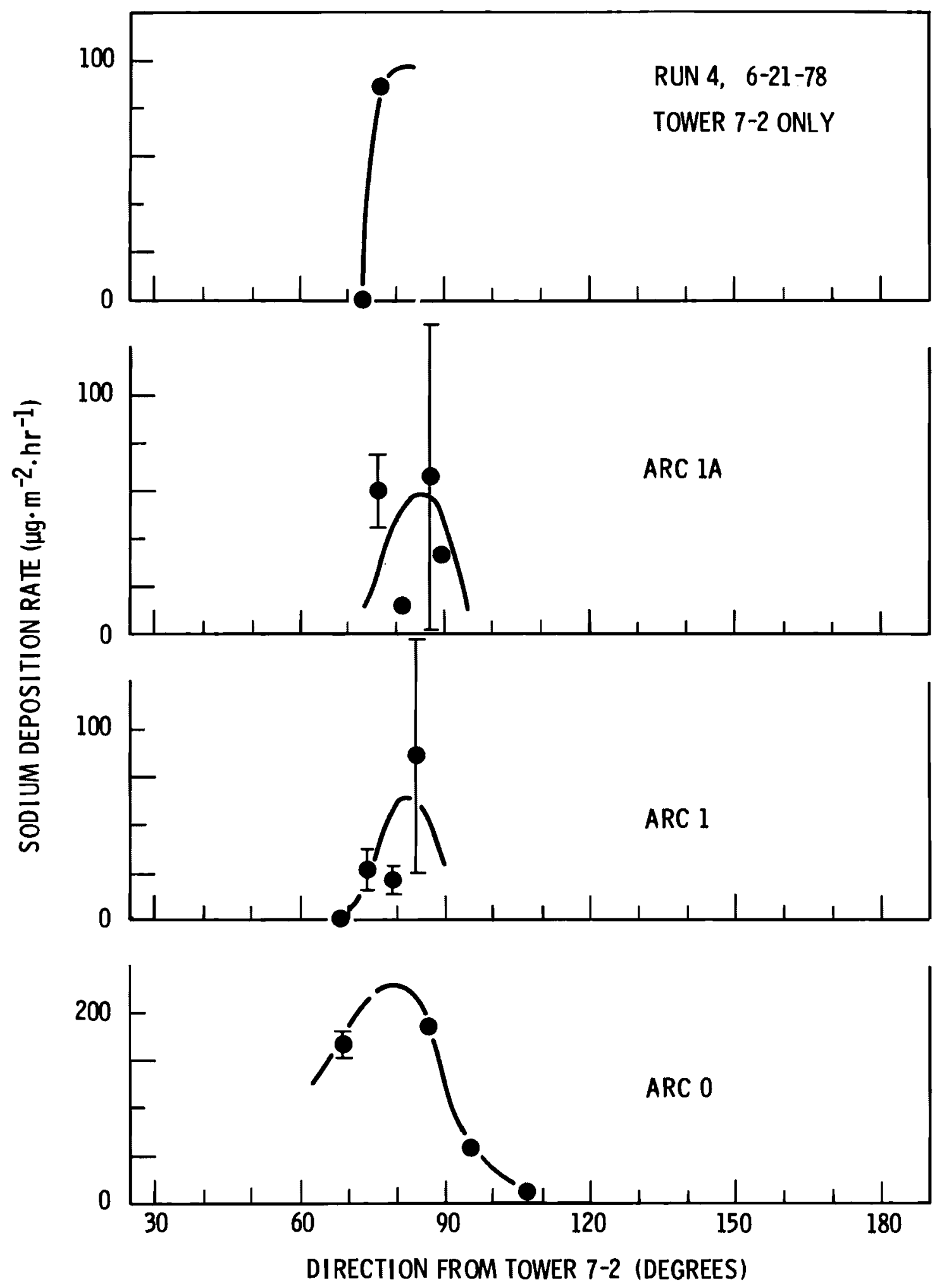

FIGURE 26. Sodium Drift Mass Deposition Pattern for Test Run 4, 6-21-78, with Tower 7-2 Operating Only 


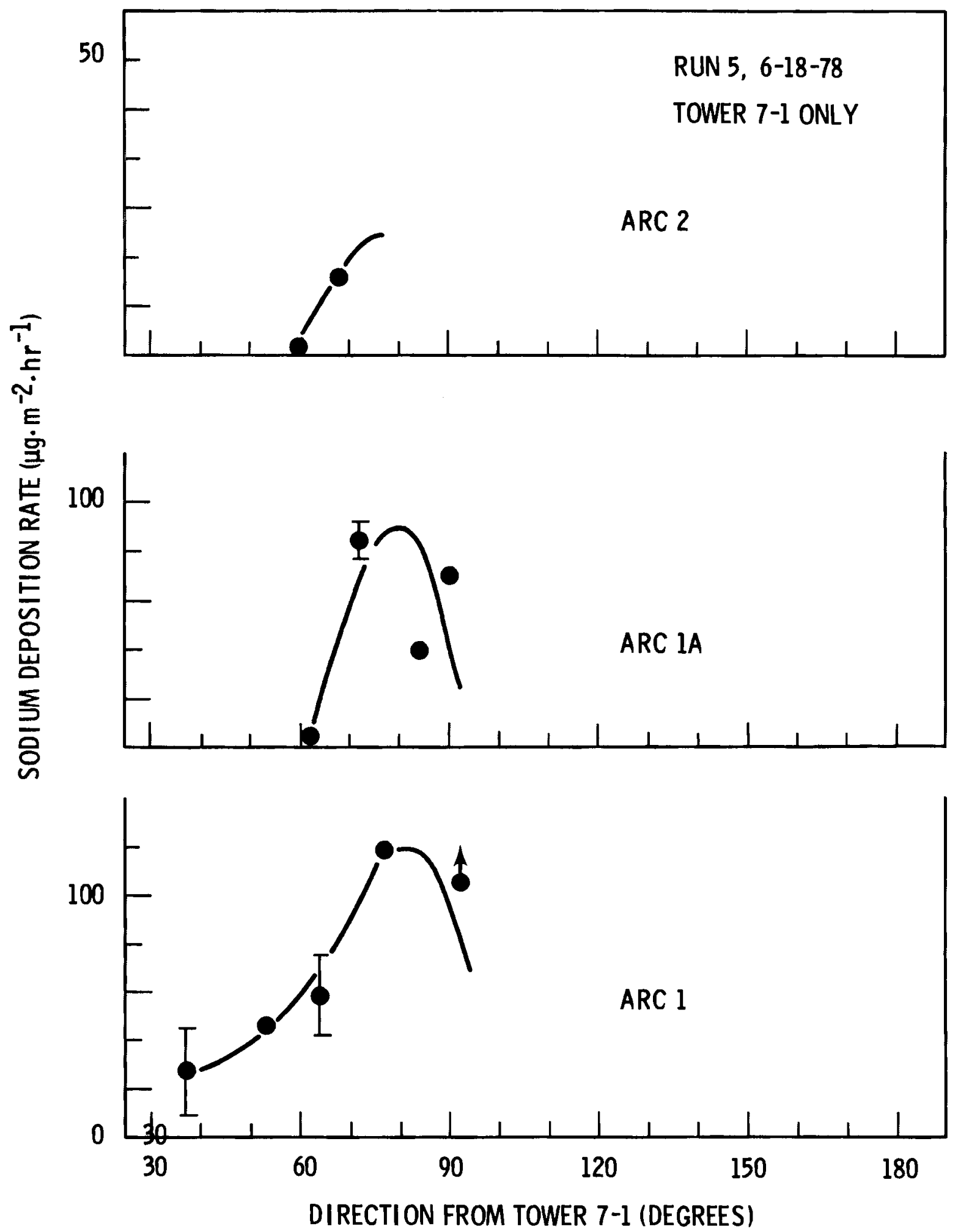

FIGURE 27. Sodium Drift Mass Deposition Pattern for Test Run 5, 6-18-78, with Tower 7-1 Operating On1y 


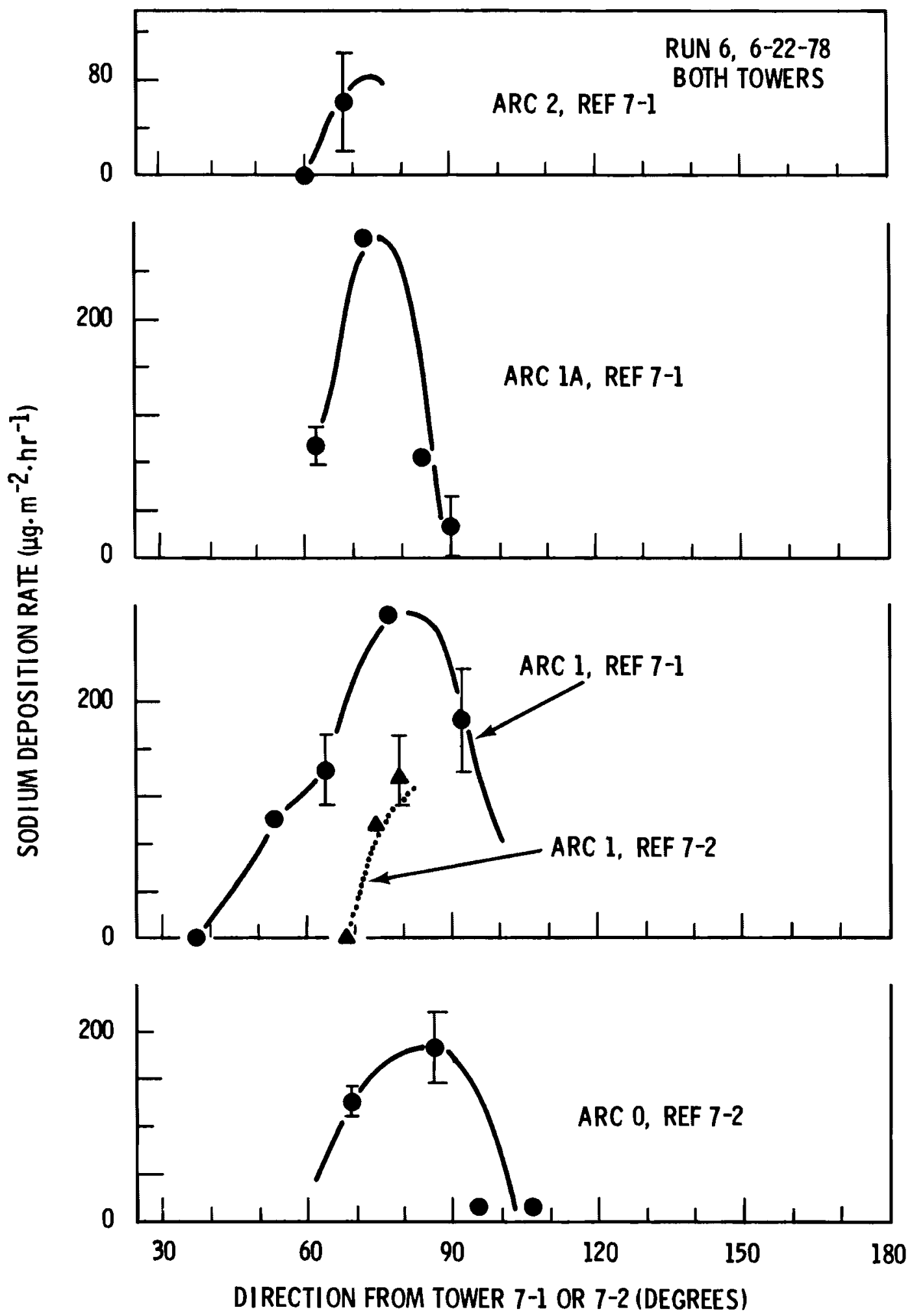

FIGURE 28. Sodium Drift Mass Deposition Pattern for Test Run 6, 6-27-78, with Both Towers Operating 


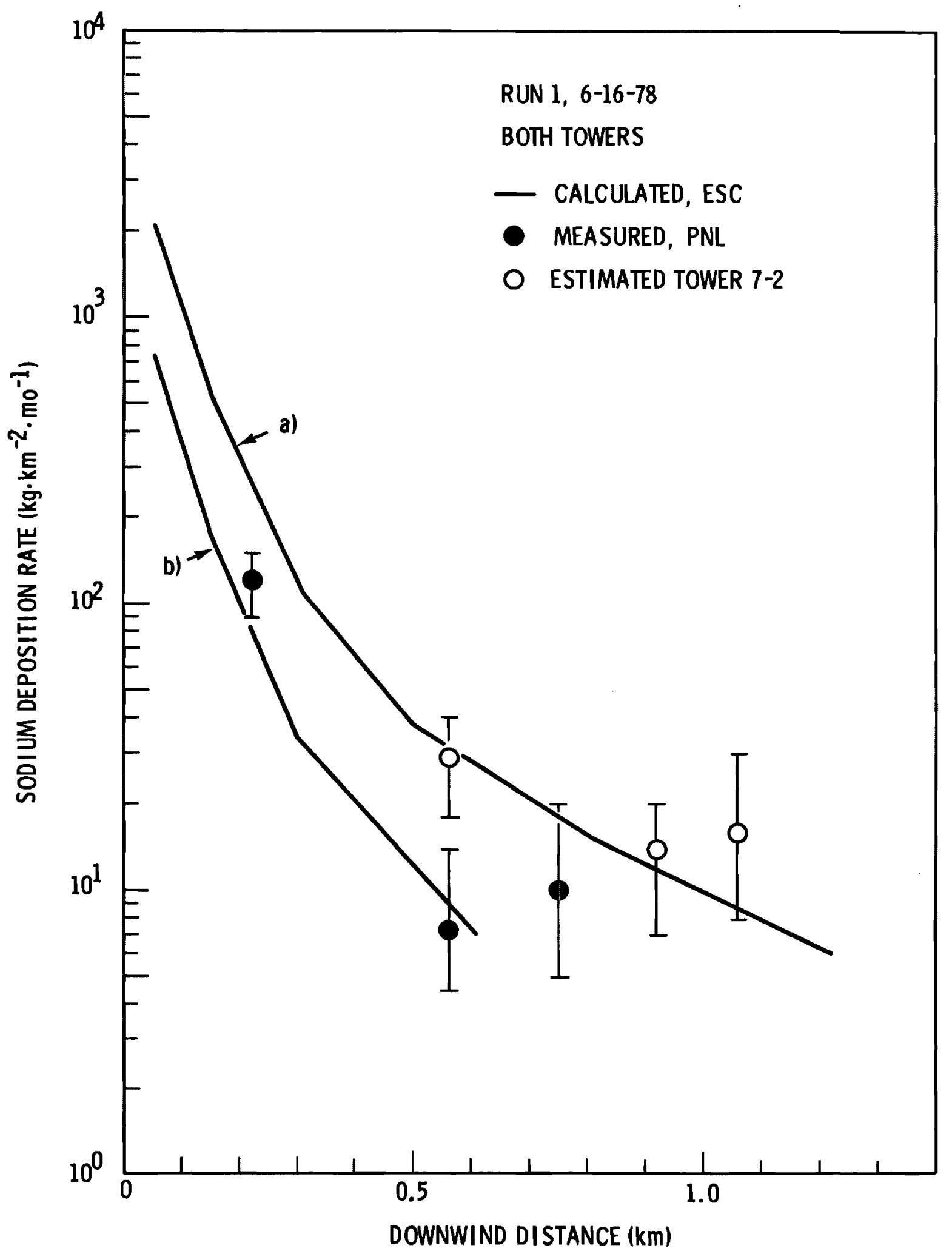

FIGURE 29. Sodium Drift Deposition Rate as a Function of Downwind Distance for Test Run 1, 6-16-78, with Both Towers Operating. Experimental Values are Compared to Those Calculated by ESC for a Droplet Salinity of a) $750 \mathrm{ppm}$ and b) $250 \mathrm{ppm}$ 


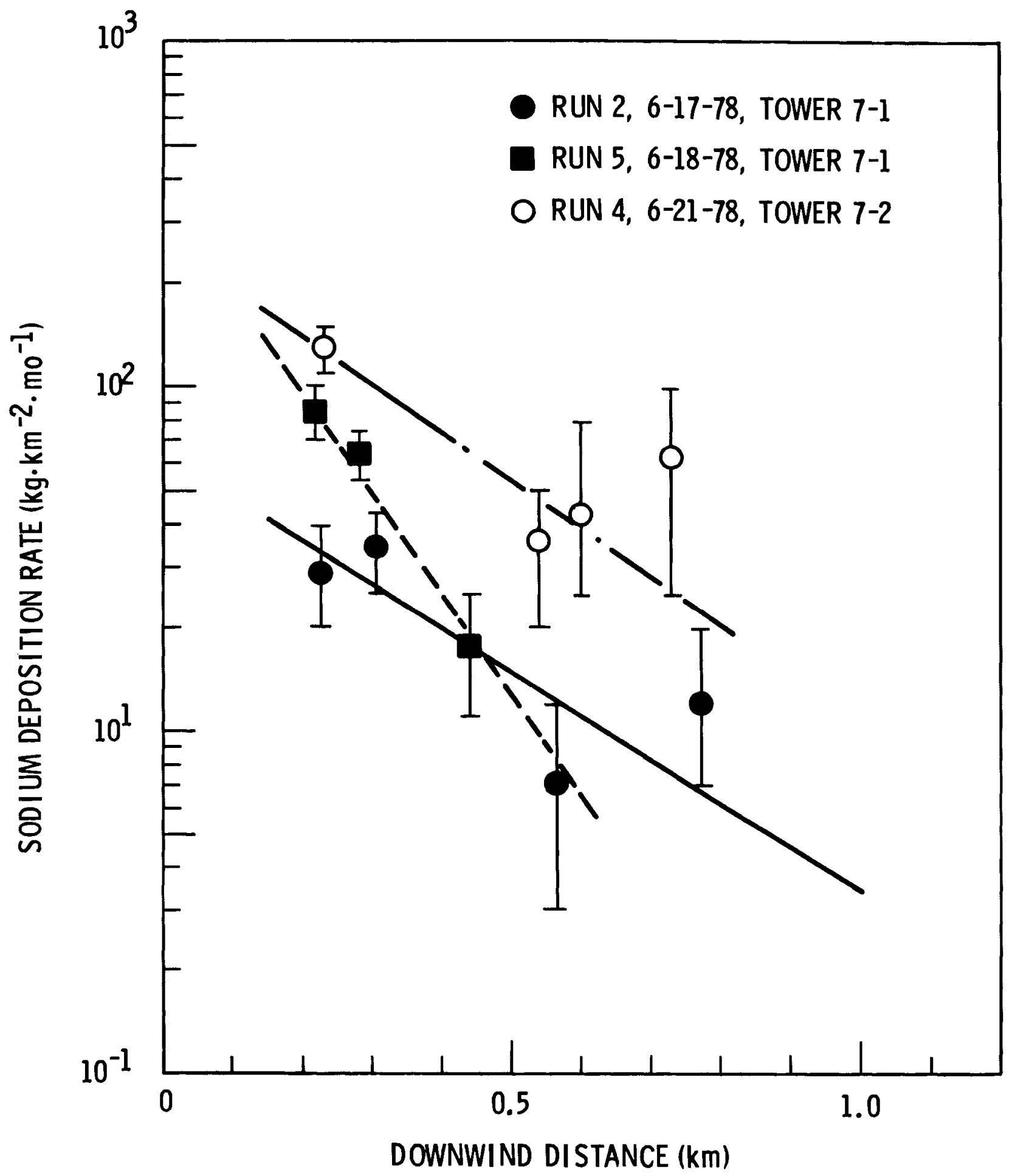

FIGURE 30. Sodium Drift Deposition Rates as a Function of Downwind Distance for Test Runs 2, 4 and 5 for Single Tower Operation Only 


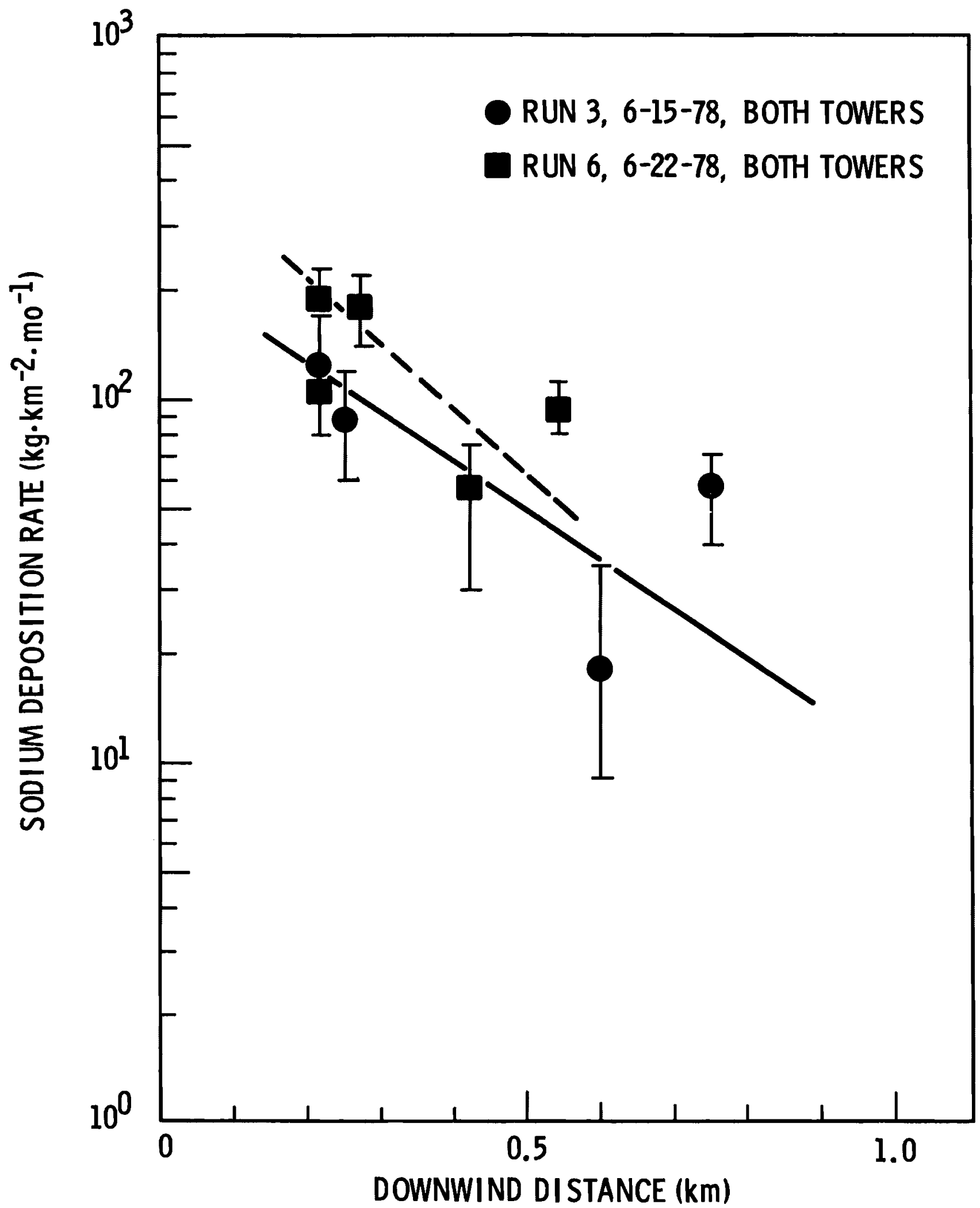

FIGURE 31. Sodium Drift Deposition Rates as a Function of Downwind Distance for Test Runs 3 and 6 , with Both Towers Operating 
The bulk deposition collectors (buckets) however cannot distinguish whether or not the collected particles are wet or dry nor can they distinguish the origin of the deposited particles. Consequently the material collected in the buckets may arise from drift, background sources or local contamination such as dust from vehicular traffic or dust resuspended from the ground by wind gusts. As discussed earlier the samples were analyzed for a variety of potential tracer ions so that some redundancy would be available to distinguish drift from background. A description of the procedure used to separate drift from the background follows.

A special program was developed that maximizes a linear function specified by the user, subject to some set of linear constraints. The linear programming subroutine was implemented in the analysis. The function maximized was the sum of sixteen variables, a background mass and a deposited drift mass for each of the eight tons measured. When this function equaled the sum of all the masses in a bucket, then all the ion were accounted for, either as background or as deposited mass. The total mass in the bucket was decreased by the amount due to handling with any negative quantities set to zero. The handling masses were obtained by the average of six handling samples or blanks. Each sampling station was treated independently. A1l variables were taken to be greater than or equal to zero.

The linear constraints imposed were:

- For each ion the deposited mass from background plus the drift mass must be less than or equal to the total mass of that ion in the bucket. This constraint gave eight equations, one for each ion.

- The ion mass arising from background must be less than or equal to a maximum average background value. The maximum average background values were obtained by averaging the buckets assumed not to have any drift ion mass, which were usually buckets outside the plume trajectory. Again, the handling mass was subtracted from the maximum average background values. This gave another set of eight equations, one for each ion. 
- Constraints on the ratio of the mass of $\mathrm{Na}$ to the other seven ions were also imposed. It was assumed that the ratios of the deposited drift ion masses in each bucket should be close to the ratios of the ion concentrations in the canal and basin water samples. An average value for this ratio was obtained by averaging the canal and basin samples taken on the day of each test (see Appendix A). A maximum value for these ratios was set at $20 \%$ above the average values, which gave seven equations, one for each of the seven ions ratioed to $\mathrm{Na}$.

- A lower bound was set on the ratios also:

- For $\mathrm{NO}_{3}, \mathrm{NH}_{4}$, and $\mathrm{K}$, the lower bound was set at zero.

- For $\mathrm{SO}_{4}, \mathrm{Cl}, \mathrm{Ca}$, and $\mathrm{Mg}$, the lower bound was set at $20 \%$ below the average values.

This constraint gave seven equations, one for each ion ratioed to $\mathrm{Na}$.

There were 31 equations in all, one maximizing equation and 30 constraint equations. The linear programming routine thus solved a set of 31 equations with 16 unknowns. The results of this analysis are listed in Tables E2.1-E2.6 for each of the test runs. It should be noted that in many instances the sum of the drift and background values for a given station does not equal the total for that sample. The residual not accounted for could be interpreted as additional background or additional drift and thus could provide a variance estimate for the drift mass value. It is noticed readily that bucket-to-bucket and station-to-station variability was quite large in many cases.

Run 1, 6-16-78 (Fig. 23). Sodium ion mineral mass deposition patterns for each arc resemble those for the droplet pattern of Fig. 13, except that the data are much more ragged as mentioned above. It appears that contributions from Tower 7-2 can be discerned in these data also. The 
shadowing effect of the switchyards also appears on the data for arc 2. Patterns for the other major ions, $\mathrm{SO}_{4}{ }^{--}, \mathrm{Cl}^{-}, \mathrm{Ca}^{++}$and $\mathrm{Mg}^{++}$, exhibit behaviour similar to that of sodium as a consequence of the linear programming analysis. The other ions, $\mathrm{NO}_{3}{ }^{-}, \mathrm{NH}_{4}{ }^{+}$and $\mathrm{K}^{+}$, did not appear to provide suitable tracers of the drift. Little $\mathrm{NO}_{3}{ }^{-}$was found in the basin water, but variable amounts were found in the deposition buckets, indicating that it originated from nearby soil elements or sources upwind. Run 2, 6-17-78 (Fig. 24). Drift patterns appear to be consistent with winds from the $285^{\circ}$ direction. Anomalously large values for two stations on arc $1 A$ are seen. No comments on potential contamination were noted. The deposition pattern for arc 2 (as was the case in run 1) appears to be too low, indicating possible interference from the 240-kv switchyard.

Run 3, 6-15-78 (Fig. 25). Mineral mass deposition collections for this test run were very poor as many of the receptor buckets blew out of their holders. (This occurrence prompted the use of strips of masking tape to secure the buckets in subsequent runs.) Consequently, while the droplet deposition patterns were of acceptable quality, the mineral mass data from this run were of poor quality. This run was analyzed primarily because of the droplet data.

Run 4, 6-21-78 (Fig. 26). The winds were from around the $250^{\circ}$ direction, which meant that the only significant interference for the drift from Tower 7-2 was Tower 7-1; the electrical switchyards were for the most part outside (south) of the plume. Mineral mass drift deposition values appear to be too large for arc 2 (actually only station 2B showed any drift and this value appears to be too large).

Run 5, 6-18-78 (Fig. 27). Single tower (7-1) operation with relatively high winds $\left(\sim 7 \mathrm{~ms}^{-1}\right)$. Dirft was observed out to about $0.4 \mathrm{~km}$.

Run 6, 6-22-78 (Fig. 28). With both towers operating, the contribution from Tower 7-2 was barely discernible in the data for arc 1. The electrical switchyard should not have influenced the drift patterns appreciably. 
Peak or plume centerline deposition rates as a function of distance are shown in Figure 29 for $\mathrm{Na}^{+}$. Also shown are predictions made by ESC with the ESC drift deposition model for two values of the droplet salinity and the measured drift flux from the cooling towers (see preceding sections). The salinity value of $250 \mathrm{ppm}$ is an average basin water value found by ESC while the 750-ppm value is one determined by ESC using the IK and SP methods for the droplets leaving the tower.

The experimental values tend to lie within the boundaries of the two curves. From a comparison of the experimental values at $1 / 2$ and $3 / 4 \mathrm{~km}$ alone it would appear that the switchyards could have reduced the drift deposition by as much as a factor of two. This would also appear to be the case when compared to the ESC model. Values for Tower 7-2 alone were obtained from arc 0 or estimated from the apparent contributions to arcs 1, 2 and 3 . In general the values appear to be larger after the same distances than the apparent contribution from Tower 7-1; this indicates that, even though 3 fans were not operating, Tower 7-2 has a higher drift emission rate.

This apparent difference is also seen when the data for single tower operation are compared (see Fig. 30). In Fig. 30, deposition rates from Tower 7-2 (6-21-78) are larger than for the two cases for Tower 7-1 (6-1778 and 6-18-78). The other two cases of two-tower operation (6-15-78 and 6-22-78) are shown in Fig. 31. The differences here probably represent the difference between morning and afternoon deposition rates, as a result of greater evaporation and consequently a larger fraction of nondepositing drift (dry particles) in the afternoon.

Similar deposition patterns were found for the other mineral ions, including $\mathrm{Cl}^{-}, \mathrm{SO}_{4}{ }^{--}$, and $\mathrm{Ca}^{++}$. Peak deposition rates had a distance dependence similar to the $\mathrm{Na}^{+}$. Water droplet mass deposition rate had a much steeper falloff with distance than the mineral mass; this is a reasonable expectation because of evaporation of the droplets as they travel downwind. Salinity values may be calculated from the measured peak 
sodium mass and water mass deposition rates for each arc. These values for the various runs and arcs are given in Table 21 . The range of values are consistent with the emission values.

The effect of decreasing relative humidity during the course of a test run was also observed with the sensitive papers. As an example, the peak droplet mass deposition rate for the 6-16 test at station $1 \mathrm{C}$ changed from a value of $400-890 \mathrm{mg} \cdot \mathrm{m}^{-2} \mathrm{hr}^{-1}$ during the first $1.2 \mathrm{hr}$ of the test to a value of $129-321 \mathrm{mg} \cdot \mathrm{m}^{-2} \mathrm{hr}^{-1}$ during the next $1.7 \mathrm{hr}$. Similarly for the 6-17 test at station 10, the droplet mass deposition rate changed from $285-532 \mathrm{mg} \cdot \mathrm{m}^{-2} \mathrm{hr}^{-1}$ during the first $1.25 \mathrm{hr}$ to $73-144 \mathrm{mg} \cdot \mathrm{m}^{-2} \mathrm{hr}^{-1}$ during the final $2.6 \mathrm{hrs}$. Other examples are easily found in Tables 14-20. 
TABLE 21. Mean Droplet Salinity Values as a Function of Downwind Distance for Each Test Run 1

\begin{tabular}{|c|c|c|c|c|c|}
\hline $\begin{array}{l}\text { Test Run } \\
\text { No. }\end{array}$ & Date & Arc & $\begin{array}{c}\text { Peak Droplet Mass } \\
\text { Deposition Rate } \\
\left(\mathrm{mg} \cdot \mathrm{m}^{-2} \cdot \mathrm{hr} \mathrm{r}^{-1}\right)\end{array}$ & $\begin{array}{c}\text { Peak Mineral Mass } \\
\text { Depositjon Rate } \\
\left(\mu \mathrm{g} \cdot \mathrm{m}^{-2} \cdot \mathrm{hr}^{-1}\right)\end{array}$ & $\begin{array}{c}\text { Mean Droplet } \mathrm{Na}^{+} \text {Concentration } \\
(\mu \mathrm{g} / \mathrm{ml} \text { or } \mathrm{ppm})\end{array}$ \\
\hline 1 & $6-16$ & $\begin{array}{l}0 \\
1 \\
2 \\
3\end{array}$ & $\begin{array}{l}500-1400 \\
400-900 \\
4-9 \\
6-12\end{array}$ & $\begin{array}{c}120-200 \\
120-200 \\
5-20 \\
5-20\end{array}$ & $\begin{array}{l}90-400 \\
130-500 \\
550-5000 \\
420-3000\end{array}$ \\
\hline $\overrightarrow{0}$ & $6-15$ & $\begin{array}{l}0 \\
1 \\
2 \\
3\end{array}$ & $\begin{array}{c}100-220 \\
75-160 \\
6-12 \\
0\end{array}$ & $\begin{array}{c}75-130 \\
100-200 \\
10-30 \\
50-100\end{array}$ & $\begin{array}{l}340-1300 \\
620-2700 \\
800-5000 \\
\text { dry }\end{array}$ \\
\hline 5 & $6-18$ & $\begin{array}{l}1 \\
1 A \\
2\end{array}$ & $\begin{array}{c}300-1100 \\
100-250 \\
5-10\end{array}$ & $\begin{array}{c}100-140 \\
50-100 \\
10-25\end{array}$ & $\begin{array}{c}90-470 \\
200-1000 \\
1000-5000\end{array}$ \\
\hline 6 & $6-22$ & $\begin{array}{l}0 \\
1 \\
1 A \\
2\end{array}$ & $\begin{array}{l}400-1300 \\
500-2500 \\
200-450 \\
100-200\end{array}$ & $\begin{array}{r}120-180 \\
200-300 \\
200-280 \\
40-100\end{array}$ & $\begin{array}{c}90-450 \\
80-600 \\
440-1400 \\
200-1000\end{array}$ \\
\hline
\end{tabular}

The range of salinity ( $\mathrm{Na}^{+}$concentration) values reflect the upper and lower mass bounds of the droplet data and the estimate variance for the mineral mass data. 


\section{ACKNOWLEDGEMENTS}

The authors acknowledge with gratitude the efforts of John Maulbetsch of EPRI in providing funds for the source characterization part of the study. Jim Meyer of the Applied Physics Laboratory, Johns Hopkins University and Gunter Schrecker of Science Applications, Inc. provided valuable advice and consultation on experiment design and site selection. Ronnie Moore of ESC provided drift model comparison data.

The following people contributed to the success of the PNL field effort: Owen Abbey, Don Glover, Roger Schreck and John Thorp. Jane Rothert and Steve Harris carried out the chemical analysis of the drift mineral samples while Lee Daniel was in charge of the droplet sizing analysis from the SP samples. Tom Bander contributed to the statistical analysis of bulk mineral deposition results using a linear programming technique. Typing of this document was carried out primarily by Dee Hammer. 
. 


\section{REFERENCES}

Balsar, M., C. A. McNary, A. E. Nagy, R, Loveland and D. Dickson, 1976: "Remote Wind Sensing by Acoustic Radar." J. Appl. Meteor., 15, 50-58.

Chen, N.C.J., 1977: A Review of Cooling Tower Drift Deposition Models. ORNL/TM-5357, Oak Ridge NationaT Laboratory, Oak Ridge, TN, 96 pp.

Chen, N.C.J. and L. Jung, 1978: "A Mathematical Model of Drift Deposition from a Bifurcated Cooling Tower Plume." Atmos. Environ., 12, 1969-1980.

Hanna, S. R., 1978: "A Simple Drift Deposition Model Applied to the Chalk Point Dye Tracer Experiment." In Proceedings of Cooling Tower Environment1978 Symposium, May 2-4, 1978, University of Maryland (PPSP-CPCTP-22).

Little, C. G., 1969: "Acoustic Methods for Remote Probing of the Lower Atmosphere." Proc. IEEE, 57, 571-578.

McAllister, L. G., J. R. Pollard, A. R. Mahoney and P.J.R. Shaw, 1969: "Acoustic Sounding - A New Approach to the Study of Atmospheric Structure." Proc. IEEE, 57, 579-587.

Meyer, J. H. and W. D. Stanbro, 1977a: Chalk Point Cooling Tower Project Final Report FY 1977, Vol. 2, Cooling Tower Drift Dye Tracer Experiment, June 16 and 17, 1977. JHU PPSP-CPCTP-16, John Hopkins University, Applied Physics Laboratory, Laurel, MD.

Meyer, J. H. and W. D. Stanbro, 1977b: "Fluorescent Dye, A Novel Technique to Trace Cool ing Tower Drift." In Proceedings of 4th Joint Conference on the Sensing of Environmental Pollutants, November 6-11, 1977, New Orleans, LA.

Morris, A. L., D. B. Call and R. B. McBeth, 1975: "A Small Tethered Balloon Sounding System." Bull. Amer. Meteor. Soc., 9, 964-969.

Policastro, A. J., W. E. Dunn, M. L. Breig and J. P. Ziebarth, 1978: "The Chalk Point Dye Tracer Study: Validation of Models and Analysis of Field Data." In Proceedings of the 2nd Conference on Waste Heat Management and Utilization, December 4-6, 1978, Miami Beach, FL.

Schrecker, G. 0., R. 0. Webb, D. A. Rutherford and F. M. Shofner, 1975:

Drift Data Acquired on Mechanical Saltwater Cooling Devices. EPA-650/2-75-060, Environmental Systems Corporation. 
Webb, R. 0., G. 0. Schrecker and D. A. Guild, 1977: "Drift from the Chalk Point Natural Draft Brackish Water Cooling Tower: Source Definition, Downwind Measurements, Transport Modeling." In Proceedings of the Conference on Waste Heat Management and Utilization, May 9-11, 1977, Miami Beach, FL.

Webb, R. 0., D. E. Wheeler and R. D. Moore, 1978: "Variations in the Chalk Point Cooling Tower Effluent Parameters and Their Effects on Drift Transport Modeling Results." In Proceedings of Cooling Tower Environment1978 Symposium, May 2-4, 1978, University of Maryland (PPSP-CPCTP-22).

Webb, R. 0., 1979: Drift Measurements From Mechanical Draft Cooling Towers - Final Report. Environmental Systems Corporation, Knoxville, TN, $218 \mathrm{pp}$.

Webb, R. O., E. D. Culver and N. S. Laulainen, 1979: "Calibration of Special Water Sensitive Paper Including Impaction at Oblique Angles." Atmos. Environ., $x x, x x x-x x x$. 
APPENDIX A

COOL ING WATER MINERAL ANALYSIS 
TABLE A1. Basin and Canal Water Mineral Ion Concentrations During the June 1978 Pittsburg Cooling Tower Drift Study

\begin{tabular}{|c|c|c|c|c|c|c|c|c|c|c|c|}
\hline \multirow[t]{2}{*}{ Date } & \multirow[t]{2}{*}{ Time } & \multicolumn{2}{|c|}{ Location ${ }^{1}$} & \multicolumn{8}{|c|}{ Mineral Ion Concentration ${ }^{2}(\mu \mathrm{g} / \mathrm{ml})$ or $(\mathrm{ppm})$} \\
\hline & & Tower & Cel1 & $\mathrm{SO}_{4}$ & $\mathrm{NO}_{3}$ & $\mathrm{Cl} e^{-}$ & $\mathrm{NH}_{4}^{+}$ & $\mathrm{Na}^{+}$ & $k^{+}$ & $\mathrm{Ca}^{++}$ & $\mathrm{Mg}^{++}$ \\
\hline \multirow[t]{2}{*}{$6-15$} & $\begin{array}{l}1415 \\
1420 \\
1425^{3} \\
\end{array}$ & $\begin{array}{l}7-1 \\
7-2 \\
7-1\end{array}$ & $\begin{array}{l}7 \\
7 \\
7\end{array}$ & $\begin{array}{l}76 \\
85 \\
42 \\
\end{array}$ & $\begin{array}{l}<1 \\
<1 \\
1.9 \\
\end{array}$ & $\begin{array}{r}108 \\
118 \\
65 \\
\end{array}$ & $\begin{aligned} & 1.8 \\
&< 1 \\
&<1 \\
&\end{aligned}$ & $\begin{array}{r}93 \\
111 \\
48 \\
\end{array}$ & $\begin{array}{r}7.4 \\
32 \\
7.5 \\
\end{array}$ & $\begin{array}{l}17 \\
17 \\
12 \\
\end{array}$ & $\begin{array}{r}15 \\
15 \\
7.9 \\
\end{array}$ \\
\hline & Average & & & $68(23)$ & $1(1)$ & $97(28)$ & $1(1)$ & $84(32)$ & $16(14)$ & $15(3)$ & $13(4)$ \\
\hline \multirow[t]{2}{*}{$6-16$} & $\begin{array}{l}0835^{3} \\
0945^{4} \\
0946^{4} \\
0948^{4}, 5 \\
1055^{4} \\
1157^{4} \\
\end{array}$ & $\begin{array}{l}7-1 \\
7-1 \\
7-2 \\
7-2 \\
7-1 \\
7-2\end{array}$ & $\begin{array}{r}12 \\
7 \\
7 \\
7 \\
7 \\
7\end{array}$ & $\begin{array}{c}99.5 \\
171(36) \\
118(2) \\
122(28) \\
89(15) \\
103(4) \\
\end{array}$ & $\begin{array}{l}<1 \\
<1 \\
<1 \\
<1 \\
<1 \\
<1 \\
\end{array}$ & $\begin{array}{l}140 \\
177(44) \\
188(32) \\
165(24) \\
129(26) \\
134(3) \\
\end{array}$ & $\begin{array}{l}<1 \\
20 \\
19 \\
11 \\
24 \\
20\end{array}$ & $\begin{array}{r}123 \\
146 \\
94 \\
116 \\
151 \\
152 \\
\end{array}$ & $\begin{array}{r}5.4 \\
62 \\
<10 \\
14 \\
54 \\
36 \\
\end{array}$ & $\begin{array}{l}20 \\
18 \\
17 \\
17 \\
18 \\
19 \\
\end{array}$ & $\begin{array}{l}16 \\
16 \\
16 \\
16 \\
16 \\
16 \\
\end{array}$ \\
\hline & Average & & & $117(29)$ & $<1$ & $156(25)$ & $16(8)$ & $130(23)$ & $30(24)$ & $18(1)$ & 16 \\
\hline \multirow[t]{2}{*}{$6-17$} & $\begin{array}{l}0740^{4} \\
0742^{4} 5 \\
0925^{3} \\
0950 \\
1130 \\
1131^{5} \\
\end{array}$ & $\begin{array}{l}7-1 \\
7-2 \\
7-1 \\
7-1 \\
7-1 \\
7-1\end{array}$ & $\begin{array}{l}7 \\
\\
3 \\
7 \\
7\end{array}$ & $\begin{array}{l}118(7) \\
118(12) \\
69 \\
89 \\
73 \\
89 \\
\end{array}$ & $\begin{array}{l}<1 \\
<1 \\
<1 \\
<1 \\
<1 \\
<1\end{array}$ & $\begin{array}{l}358(44) \\
352(20) \\
130 \\
159 \\
145 \\
163 \\
\end{array}$ & $\begin{array}{l}<1 \\
<1 \\
<1 \\
<1 \\
<1 \\
<1\end{array}$ & $\begin{array}{r}195 \\
177 \\
109 \\
97 \\
120 \\
110 \\
\end{array}$ & $\begin{array}{l}9.5 \\
8.6 \\
4.4 \\
5.5 \\
4.7 \\
4.7 \\
\end{array}$ & $\begin{array}{l}23 \\
23 \\
15 \\
19 \\
18 \\
19 \\
\end{array}$ & $\begin{array}{l}28 \\
30 \\
13 \\
19 \\
18 \\
18 \\
\end{array}$ \\
\hline & Average & & & $93(21)$ & $<1$ & $218(107)$ & $<1$ & $135(41)$ & $6.2(22)$ & $20(3)$ & $21(7)$ \\
\hline
\end{tabular}


TABLE A1. (Continued)

\begin{tabular}{|c|c|c|c|c|c|c|c|c|c|c|c|}
\hline $6-18$ & $\begin{array}{l}0825 \\
0830^{6} \\
0830^{3} \\
0955^{3} \\
1007 \\
1120 \\
1120^{4,5} \\
1220 \\
\end{array}$ & $\begin{array}{l}7-1 \\
7-1 \\
7-1 \\
7-1 \\
7-1 \\
7-1 \\
7-1 \\
7-1\end{array}$ & $\begin{array}{l}7 \\
9 \\
9 \\
9 \\
7 \\
7\end{array}$ & $\begin{array}{l}126 \\
138(18) \\
101 \\
36 \\
98 \\
92 \\
120(5) \\
101 \\
\end{array}$ & $\begin{aligned}<1 \\
<1 \\
1.9 \\
<1 \\
<1 \\
<1 \\
<1 \\
<1\end{aligned}$ & $\begin{array}{l}417 \\
424 \\
512 \\
299 \\
278 \\
239 \\
296(28) \\
213 \\
\end{array}$ & $\begin{array}{l}<1 \\
<1 \\
<1 \\
12 \\
<1 \\
<1 \\
<1 \\
<1\end{array}$ & $\begin{array}{l}217 \\
312 \\
277 \\
210 \\
184 \\
160 \\
129 \\
147 \\
\end{array}$ & $\begin{array}{l}12.4 \\
33 \\
11 \\
8.1 \\
8.3 \\
6.7 \\
18 \\
6.8 \\
\end{array}$ & $\begin{array}{l}25 \\
25 \\
25 \\
23 \\
21 \\
21 \\
21 \\
20 \\
\end{array}$ & $\begin{array}{l}34 \\
32 \\
32 \\
26 \\
25 \\
24 \\
24 \\
22 \\
\end{array}$ \\
\hline & Average & & & $102(31)$ & $<1$ & $355(104)$ & $2(4)$ & $205(64)$ & $13(9)$ & $23(2)$ & $27(5)$ \\
\hline $6-20$ & $\begin{array}{l}0936^{4} \\
0937^{4}, 5 \\
1026 \\
1040^{3} \\
1154 \\
\end{array}$ & $\begin{array}{l}7-2 \\
7-2 \\
7-2 \\
7-2 \\
7-2\end{array}$ & $\begin{array}{l}7 \\
7 \\
7\end{array}$ & $\begin{array}{l}159(1) \\
149(29) \\
146 \\
130 \\
108 \\
\end{array}$ & $\begin{array}{r}<1 \\
<1 \\
<1 \\
2.6 \\
<1 \\
\end{array}$ & $\begin{array}{l}576(46) \\
584(108) \\
532 \\
367 \\
374 \\
\end{array}$ & $\begin{array}{l}<1 \\
<1 \\
<1 \\
<1 \\
<1\end{array}$ & $\begin{array}{l}310 \\
290 \\
326 \\
420 \\
256 \\
\end{array}$ & $\begin{array}{l}10 \\
12 \\
13 \\
15 \\
8.6 \\
\end{array}$ & $\begin{array}{l}30 \\
30 \\
28 \\
28 \\
28 \\
\end{array}$ & $\begin{array}{l}44 \\
44 \\
39 \\
39 \\
34 \\
\end{array}$ \\
\hline & Average & & & $138(20)$ & $1(1)$ & $487(108)$ & $<1$ & $320(62)$ & $12(3)$ & $29(1)$ & $40(4)$ \\
\hline $6-21$ & $\begin{array}{l}0730 \\
0732 \\
0734^{5} \\
0827 \\
1053 \\
1158 \\
\end{array}$ & $\begin{array}{l}7-1 \\
7-2 \\
7-2 \\
7-2 \\
7-2 \\
7-2\end{array}$ & $\begin{array}{l}7 \\
7 \\
7\end{array}$ & $\begin{array}{l}191 \\
219 \\
140 \\
165 \\
190 \\
180 \\
\end{array}$ & $\begin{array}{l}<1 \\
<1 \\
<1 \\
<1 \\
<1 \\
2.3 \\
\end{array}$ & $\begin{array}{l}893 \\
886 \\
478 \\
766 \\
796 \\
689 \\
\end{array}$ & $\begin{aligned}<1 \\
<1 \\
4.4 \\
<1 \\
<1 \\
2.2 \\
2\end{aligned}$ & $\begin{array}{l}506 \\
432 \\
330 \\
466 \\
420 \\
547 \\
\end{array}$ & $\begin{array}{l}16 \\
18 \\
18 \\
14.3 \\
11.4 \\
13 \\
\end{array}$ & $\begin{array}{l}35 \\
34 \\
27 \\
36 \\
32 \\
33 \\
\end{array}$ & $\begin{array}{l}57 \\
56 \\
37 \\
58 \\
51 \\
52 \\
\end{array}$ \\
\hline & Average & & & $181(27)$ & $1(1)$ & $751(154)$ & $2(2)$ & $450(75)$ & $15(3)$ & $33(3)$ & $52(8)$ \\
\hline
\end{tabular}


TABLE Al, (Continued)

\begin{tabular}{|c|c|c|c|c|c|c|c|c|c|c|c|}
\hline \multirow[t]{2}{*}{$6-22$} & $\begin{array}{l}0630^{3} \\
0904 \\
0912 \\
0912^{5} \\
0920^{3} \\
1057 \\
1100 \\
\end{array}$ & $\begin{array}{l}7-2 \\
7-1 \\
7-2 \\
7-2 \\
7-2 \\
7-1 \\
7-2\end{array}$ & $\begin{array}{r}12 \\
7 \\
7 \\
3 \\
7 \\
7\end{array}$ & $\begin{array}{l}184 \\
193 \\
194 \\
157 \\
200 \\
188 \\
187 \\
\end{array}$ & $\begin{array}{r}1.2 \\
3.8 \\
3.4 \\
1.9 \\
<1 \\
3.2 \\
2.6\end{array}$ & $\begin{array}{r}876 \\
942 \\
933 \\
641 \\
1050 \\
903 \\
931 \\
\end{array}$ & $\begin{array}{l}<1 \\
1.1 \\
<1 \\
<1 \\
<1 \\
<1 \\
<1\end{array}$ & $\begin{array}{l}493 \\
820 \\
840 \\
517 \\
824 \\
590 \\
739 \\
\end{array}$ & $\begin{array}{l}14 \\
47 \\
50 \\
17 \\
18 \\
21 \\
16 \\
\end{array}$ & $\begin{array}{l}35 \\
38 \\
38 \\
31 \\
37 \\
37 \\
38 \\
\end{array}$ & $\begin{array}{l}56 \\
66 \\
65 \\
50 \\
62 \\
64 \\
64 \\
\end{array}$ \\
\hline & Average & & & $186(14)$ & $2.4(11)$ & $897(125)$ & $<1$ & $689(152)$ & $26(15)$ & $36(3)$ & $61(6)$ \\
\hline $6-24$ & $\begin{array}{l}0756 \\
0857 \\
1001 \\
1114 \\
1115^{5} \\
1215\end{array}$ & $\begin{array}{l}7-1 \\
7-1 \\
7-1 \\
7-1 \\
7-1 \\
7-1\end{array}$ & $\begin{array}{l}7 \\
7 \\
7 \\
7 \\
7\end{array}$ & $\begin{array}{l}228 \\
204 \\
190 \\
188 \\
187 \\
182 \\
\end{array}$ & $\begin{array}{l}3.4 \\
3.4 \\
3.1 \\
2.9 \\
2.9 \\
2.2\end{array}$ & $\begin{array}{r}1250 \\
1060 \\
910 \\
814 \\
810 \\
770\end{array}$ & $\begin{array}{l}<1 \\
<1 \\
<1 \\
<1 \\
<1 \\
<1\end{array}$ & $\begin{array}{l}813 \\
895 \\
617 \\
606 \\
483 \\
501\end{array}$ & $\begin{array}{l}33 \\
43 \\
30 \\
22.5 \\
24 \\
20\end{array}$ & $\begin{array}{l}43 \\
42 \\
39 \\
38 \\
38 \\
37\end{array}$ & $\begin{array}{l}80 \\
70 \\
64 \\
59 \\
59 \\
57\end{array}$ \\
\hline & Average & & & $197(17)$ & $3.0(4)$ & $936(186)$ & $<1$ & $652(167)$ & $29(9)$ & $40(3)$ & $65(9)$ \\
\hline
\end{tabular}

\footnotetext{
IUnless noted otherwise, samples were taken at the bottom, center, south side (cold water) of the cooling tower.

${ }^{2}$ Shorthand notation for standard deviation used, e.g., $68(23)=68 \quad 23,6.2(22)=6.2 \quad 2.2$, etc. ${ }^{3}$ ESC water sample taken at the top (hot water) of the cooling tower, but analyzed by PNL.

${ }^{4}$ Repeated analys is of the same water sample.

${ }^{5}$ Canal water sample taken in the hot water leg.

${ }^{6}$ Split hot water sample with ESC, but analyzed separately from the ESC sample.
} 
APPENDIX B

SAMPL ING STATION IDENTIF ICATION 
Table B1. Sampling Station, line of sight to Cooling Towers

and photograph (negative) cross reference.

All photos taken on 14 June 1979 unless otherwise noted.

\begin{tabular}{|c|c|c|c|}
\hline Figure No. & Station & $\begin{array}{c}\text { Negative } \\
\text { ID }\end{array}$ & Direction of Observation, Comment \\
\hline B la & UUA & $2-14$ & Upwind, Canal \\
\hline $\mathrm{b}$ & UUA & $2-12$ & Both Towers, Plant \\
\hline c & UUB & $2-16$ & Upwind, Canal \\
\hline d & UUB & $2-15$ & Both towers, Plant \\
\hline B 2a & UA & $2-11$ & Upwind, Canal \\
\hline b & UA & $2-10$ & Both towers \\
\hline c & UB & $2-18$ & Upwind, Canal \\
\hline d & UB & $2-17$ & Both towers \\
\hline B 3a & $O A$ & $1-3$ & Tower 7-1 \\
\hline b & $O A$ & $1-4$ & Tower 7-2 \\
\hline c & OBN & $3-7$ & Tower 7-2, Plant \\
\hline d & OBN & $3-8$ & Tower 7-2, Canal \\
\hline B $4 a$ & OBS & $3-5$ & Tower 7-1 \\
\hline b & OBS & $3-6$ & Tower 7-2 \\
\hline c & OC & $3-4$ & Tower 7-1 \\
\hline d & OC & $3-3$ & Tower 7-2 \\
\hline B $5 a$ & OD & $3-2$ & Tower 7-1 \\
\hline b & OD & $2-21$ & Tower 7-2 \\
\hline c & OE & $2-19$ & Tower 7-1 \\
\hline d & $\mathrm{OE}$ & $2-20$ & Tower 7-2 \\
\hline B $6 a$ & $1 Z Z$ & $5-15$ & Tower $7-1,6-24-79$ \\
\hline b & $12 z$ & $5-14$ & Tower 7-2, 6-24-79 \\
\hline c & $1 x$ & $5-17$ & Tower 7-1, 6-24-79 \\
\hline d & $1 x$ & $5-16$ & Tower $7-2,6-24-79$ \\
\hline B $7 a$ & 12 & $4-11$ & Tower $7-1,6-18-79$ \\
\hline b & 12 & $4-10$ & Tower 7-2, 6-18-79 \\
\hline c & 12 & $4-12$ & Upwind, Suisun Bay, 6-18-79 \\
\hline d & $1 Y$ & $4-13$ & Both towers, 6-18-79 \\
\hline
\end{tabular}




\begin{tabular}{|c|c|c|c|}
\hline Figure No. & Station & $\begin{array}{l}\text { Negative } \\
\text { ID }\end{array}$ & Direction of Observation, Comment \\
\hline B $8 a$ & $1 \mathrm{~A}$ & $1-2$ & Both towers \\
\hline b & 1B & $1-5$ & Both towers \\
\hline c & IC & $1-6$ & Both towers \\
\hline d & 10 & $1-7$ & Both towers \\
\hline B 9a & IE & $1-10$ & Both towers \\
\hline b & IE, IF & $3-17$ & $\begin{array}{c}\text { Both towers, acoustic sounder, all sky } \\
\text { camera, bolex camera. }\end{array}$ \\
\hline c & $\mathrm{IF}$ & $1-8$ & Both towers, but mostly $7-1$ \\
\hline d & IF & $1-9$ & Both towers, but mostly $7-2$ \\
\hline B10a & 16 & $2-9$ & Tower 7-1 \\
\hline b & IG & $2-8$ & Tower 7-2 \\
\hline c & $\mathrm{IH}$ & $4-16$ & $\begin{array}{c}\text { Tower } 7-1,6-19-79 \text {, not used in sampling } \\
\text { program. }\end{array}$ \\
\hline d & $\mathrm{IH}$ & $4-20 A$ & $\begin{array}{c}\text { Tower } 7-2, \begin{array}{l}6-19-79, \\
\text { program. }\end{array}\end{array}$ \\
\hline Blla & $1 \mathrm{I}$ & $3-14$ & Tower 7-1 \\
\hline$b$ & $1 I$ & $3-13$ & Tower 7-2 \\
\hline c & $1 \mathrm{~J}$ & $3-12$ & Tower 7-1 \\
\hline d & $1 \mathrm{~J}$ & $3-11$ & Tower 7-2 \\
\hline B12a & IAZ & $4-9$ & Both towers, 6-18-79 \\
\hline b & IAA & $4-8$ & Both towers, 6-18-79 \\
\hline c & $I A B$ & 4-7 & Both towers, 6-18-79 \\
\hline d & IAC & $4-6$ & Both towers, 6-18-79 \\
\hline B13a & IAD & 4-5 & Both towers, 6-18-79 \\
\hline b & IAE & $4-4$ & Both towers, 6-18-79 \\
\hline c & IAF & $4-3$ & Both towers, 6-18-79 \\
\hline d & $1 F$ & $3-15$ & $\begin{array}{l}\text { Both towers, PG\&E Meteorology hut, cameras } \\
\text { acoust ic sounder. }\end{array}$ \\
\hline B14a & $2 A$ & $1-11$ & Both towers \\
\hline$b$ & $2 B$ & $1-12$ & Both towers \\
\hline c & $2 \mathrm{E}$ & $1-13$ & Both towers, switchyard \\
\hline$d$ & $2 F$ & $1-14$ & Both towers, switchyard \\
\hline B15a & $2 G$ & $1-15$ & Both towers, switchyard \\
\hline b & $2 H$ & $1-16$ & Both towers, \\
\hline c & $2 \mathrm{I}$ & $2-4$ & Both towers \\
\hline d & $2 \mathrm{~J}$ & $2-5$ & Both towers \\
\hline
\end{tabular}




\begin{tabular}{c|c|c|l} 
Figure No. & Station & $\begin{array}{c}\text { Negative } \\
\text { ID }\end{array}$ & Direction of Observation, Comment \\
\hline Bl6a & 2 K & $2-6$ & Tower 7-1 \\
b & 2K & $2-7$ & Tower 7-2 \\
C & 3A & $1-17$ & Both towers, switchyard \\
d & 3B & $1-18$ & Both towers, switchyard \\
Bl7a & 3C & $1-20$ & Both towers, switchyard \\
b & 3E & $2-2$ & Both towers, switchyard \\
C & 3F & $2-3$ & Both towers \\
d & IF & $4-14$ & Both towers, Acoustic sounder
\end{tabular}




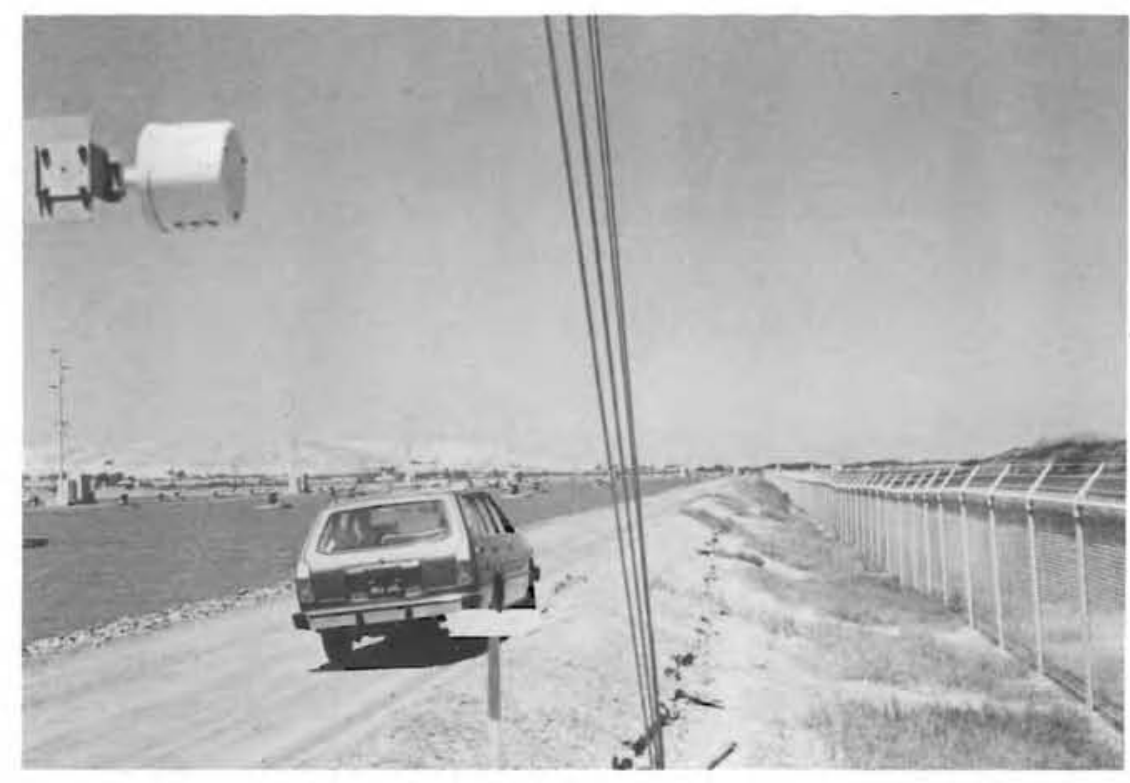

a

$\stackrel{D}{\infty}$

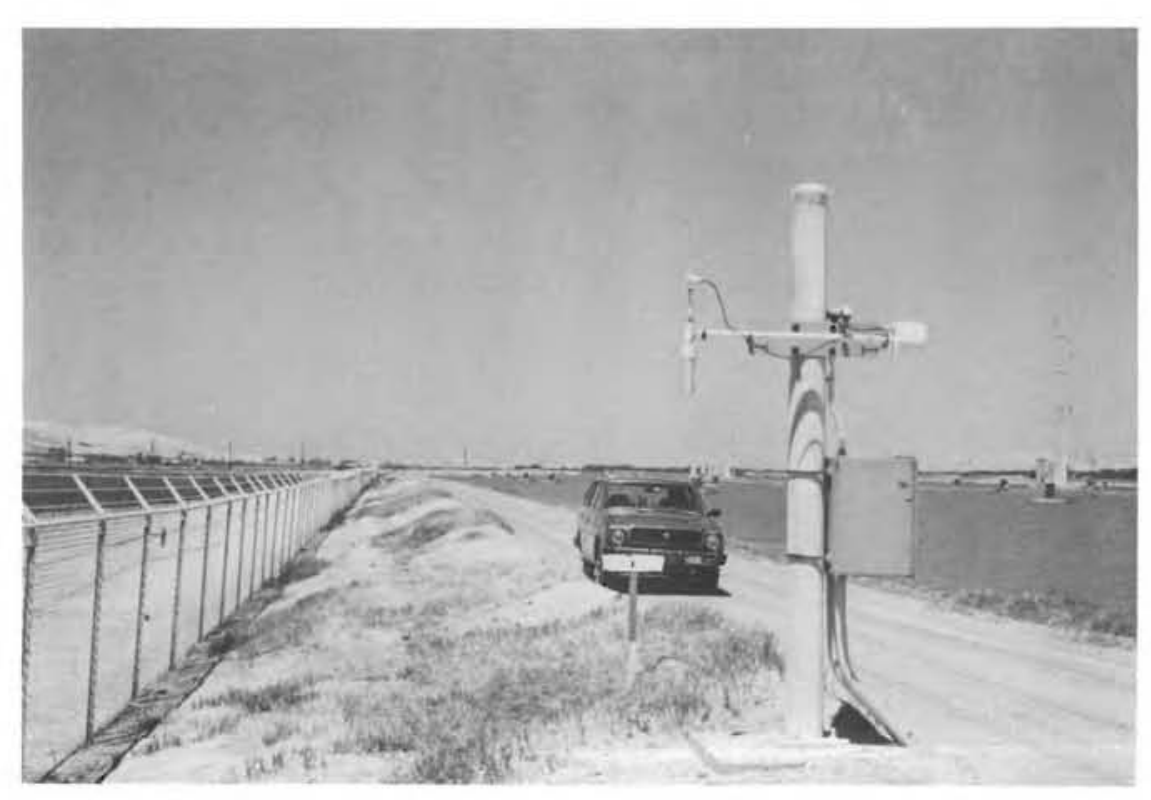

c

Figure B 1

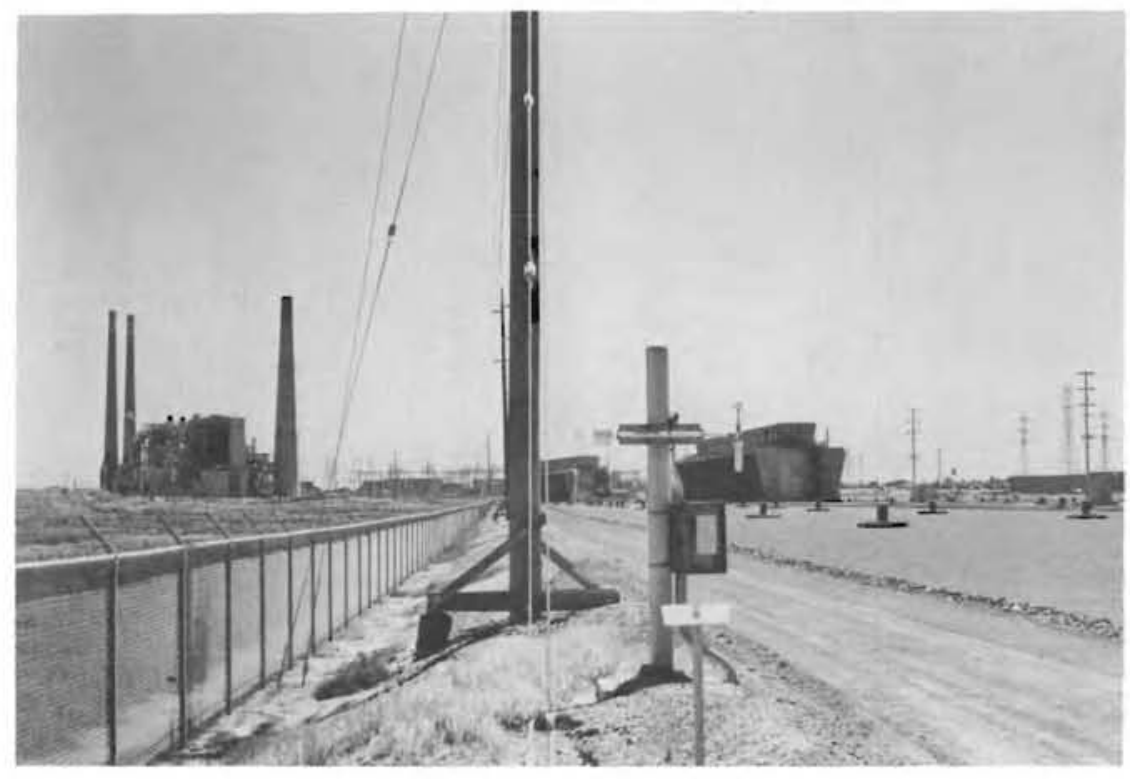

b

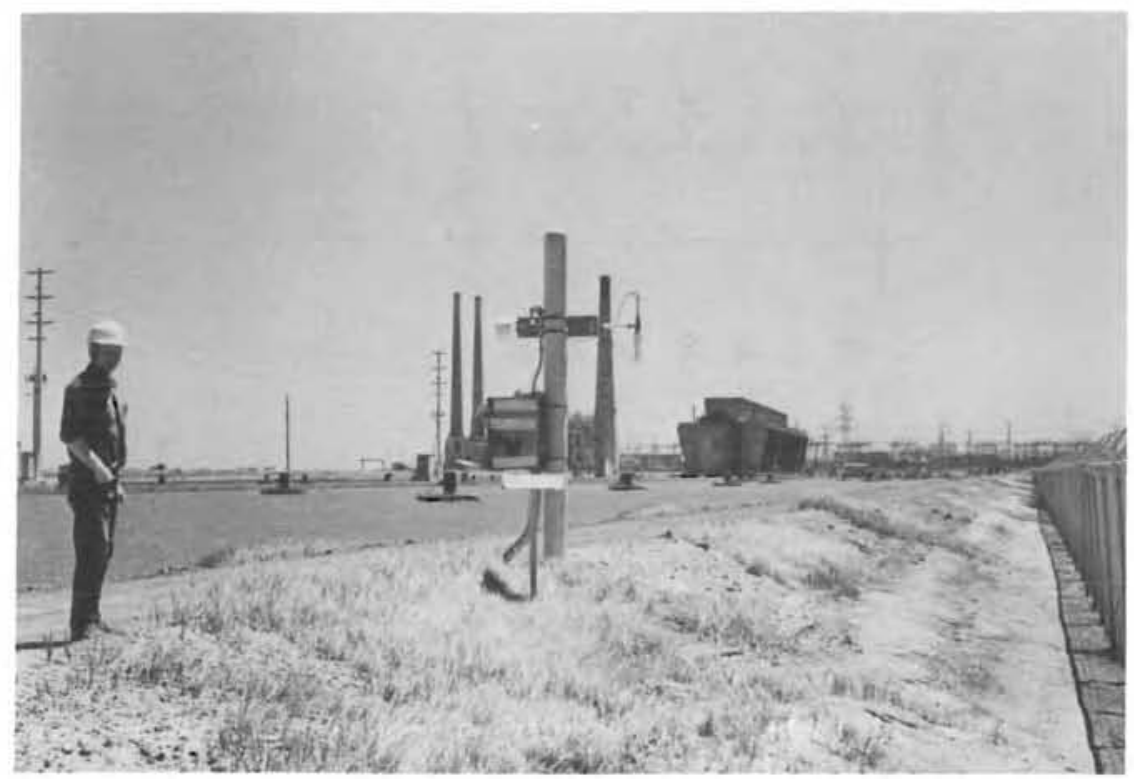



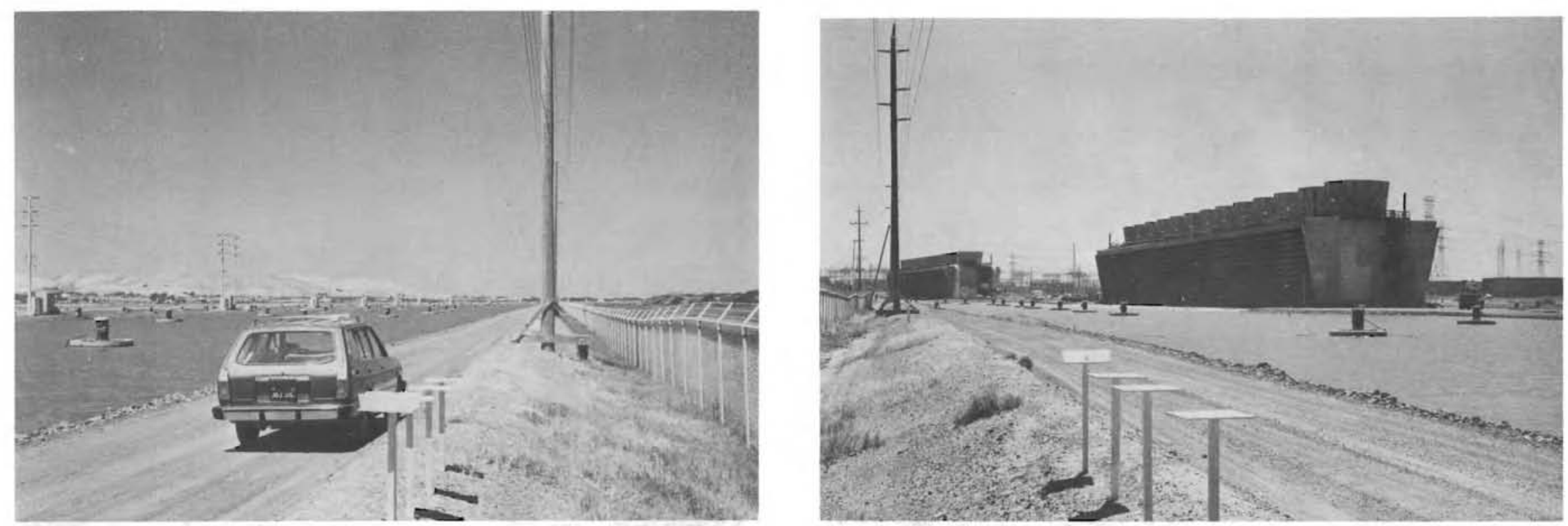

घ́

b
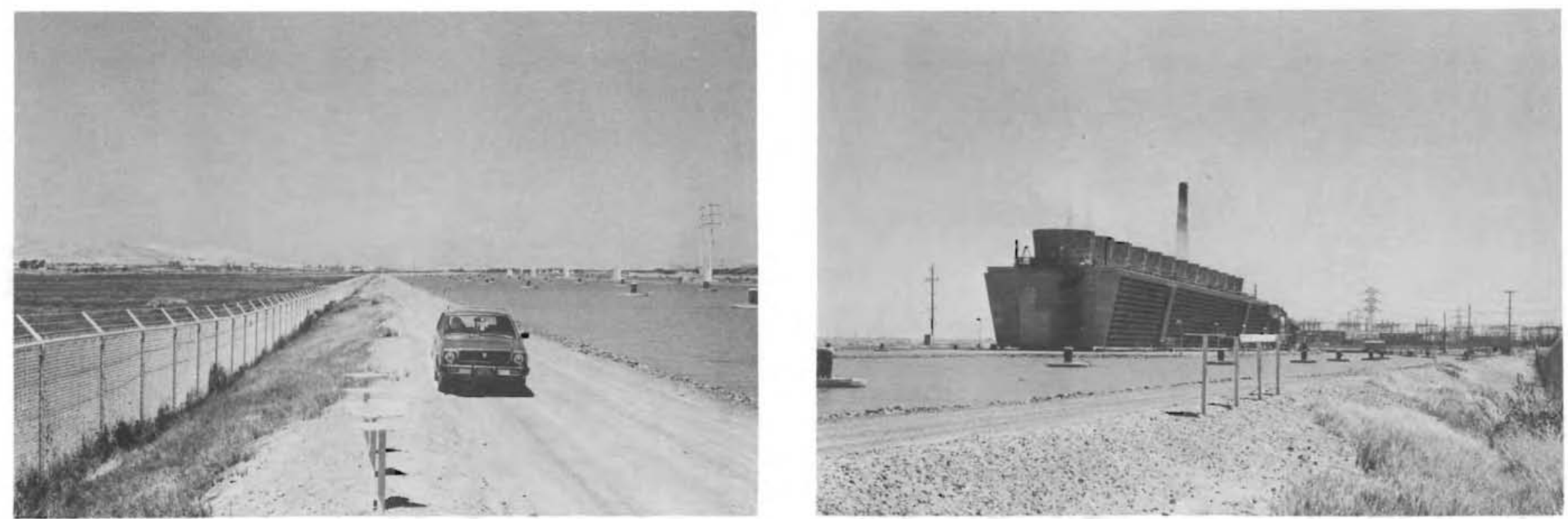

Figure B 2 

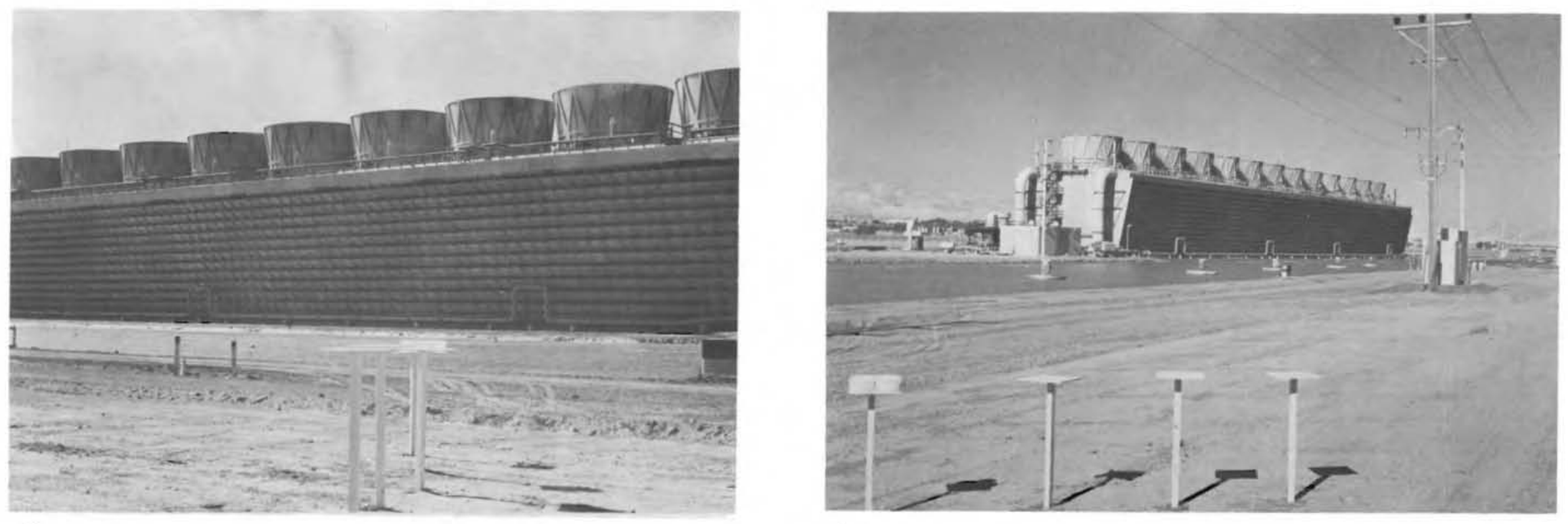

டு

a

b

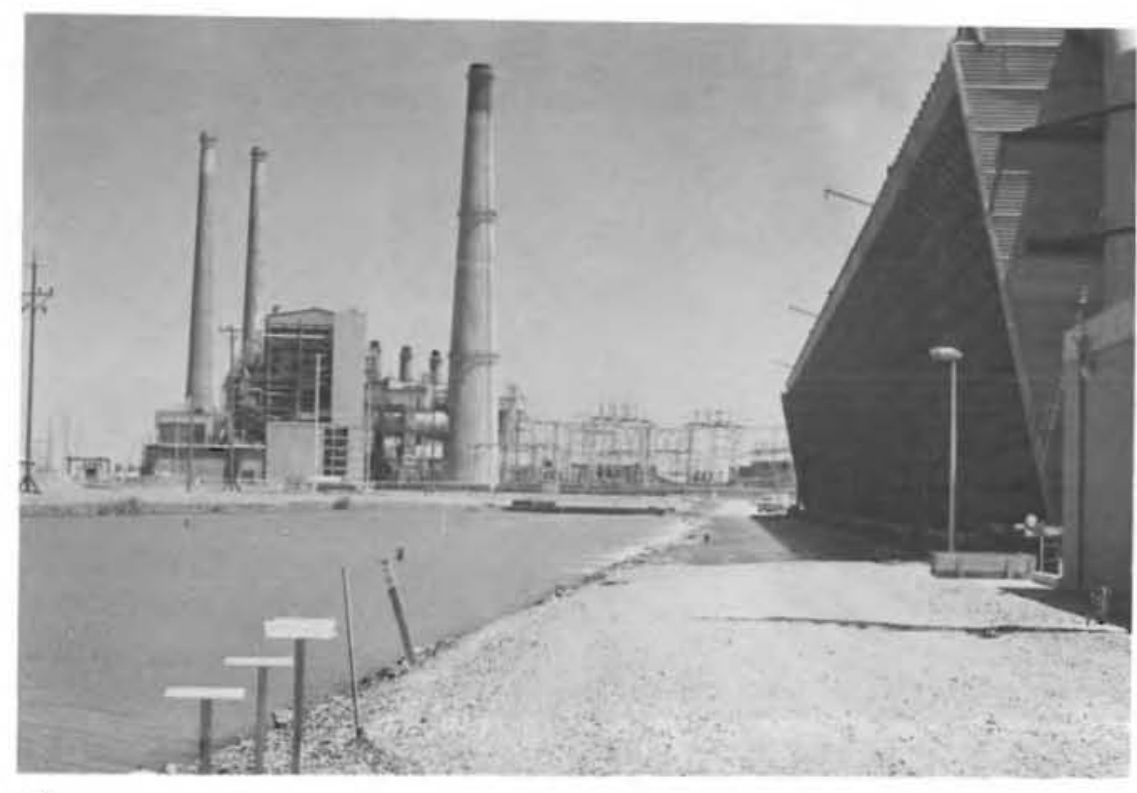

C

Figure B 3

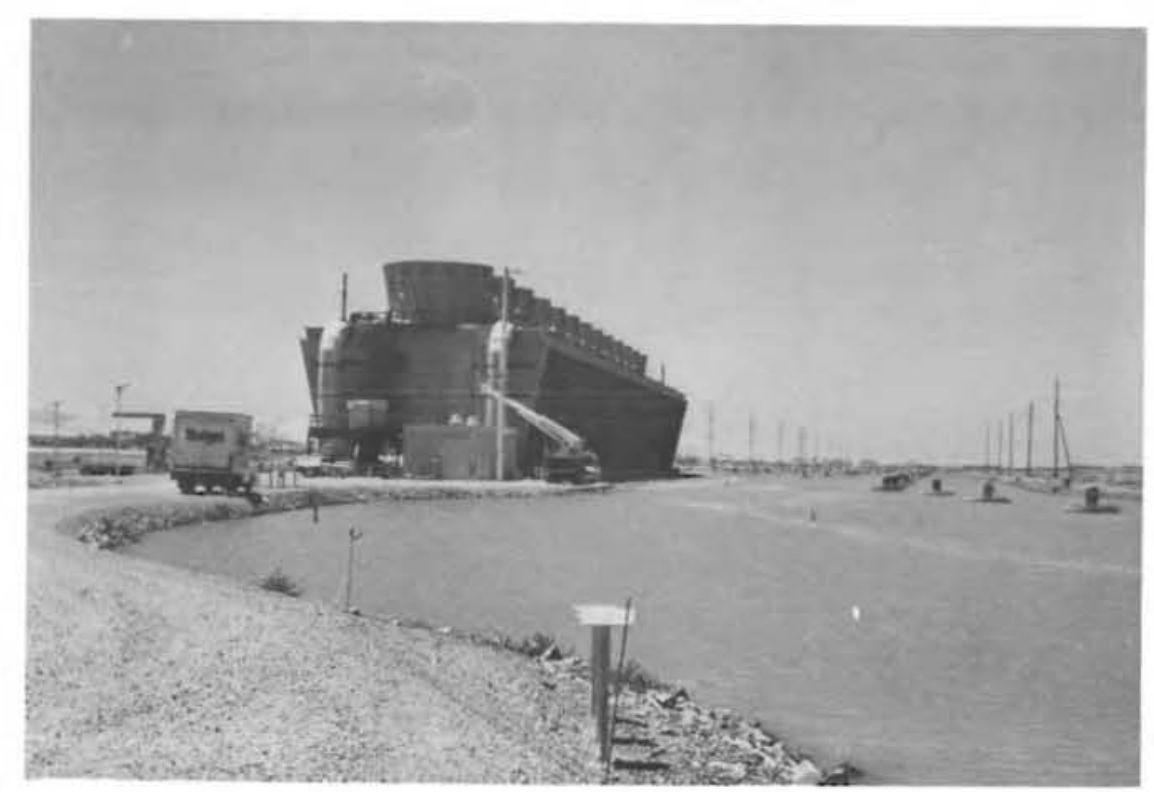



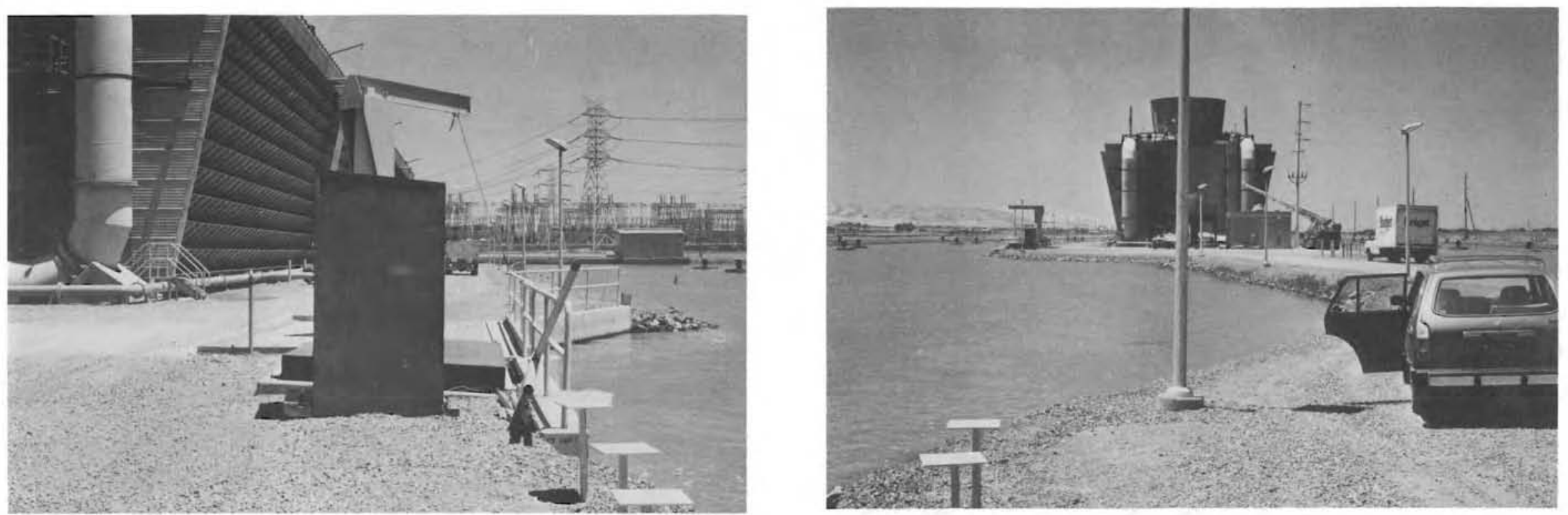

$\stackrel{D}{i}$

a

b
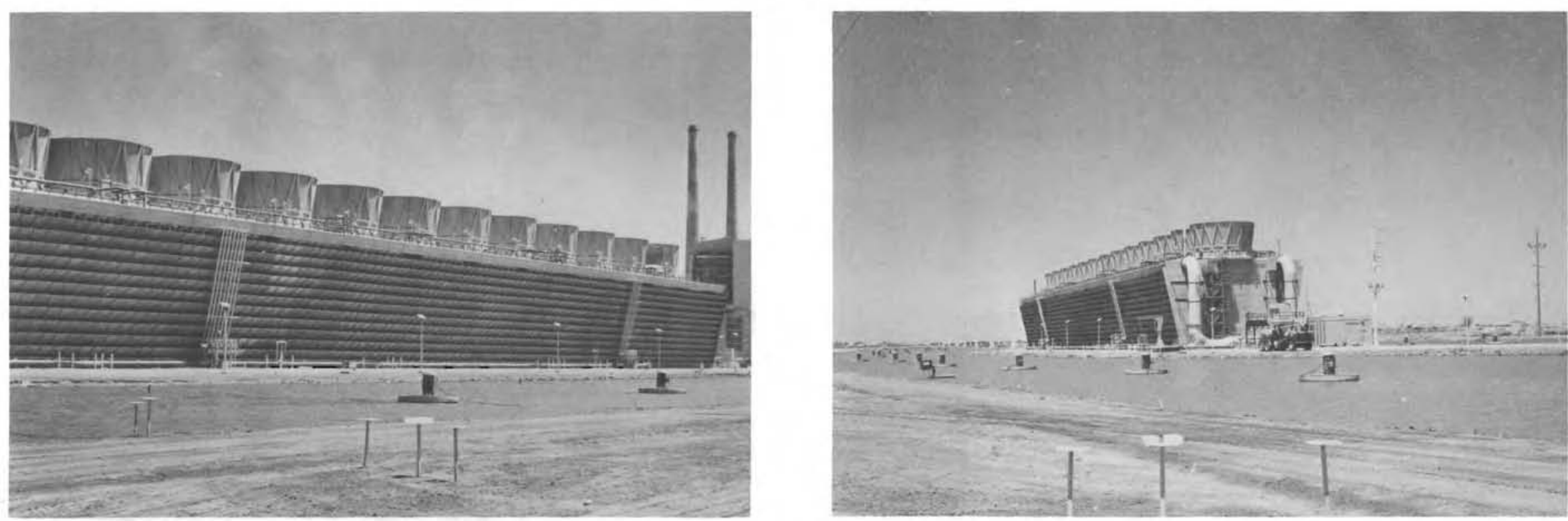


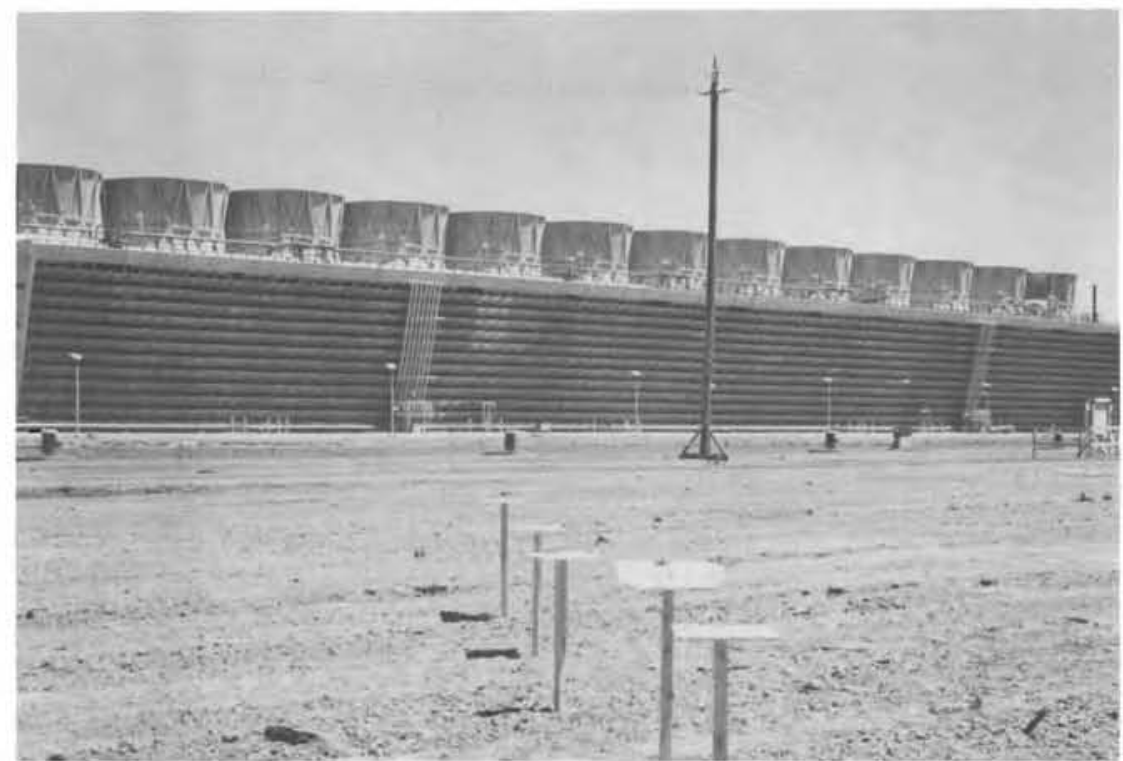

$\infty$
1
$\infty$
$\infty$

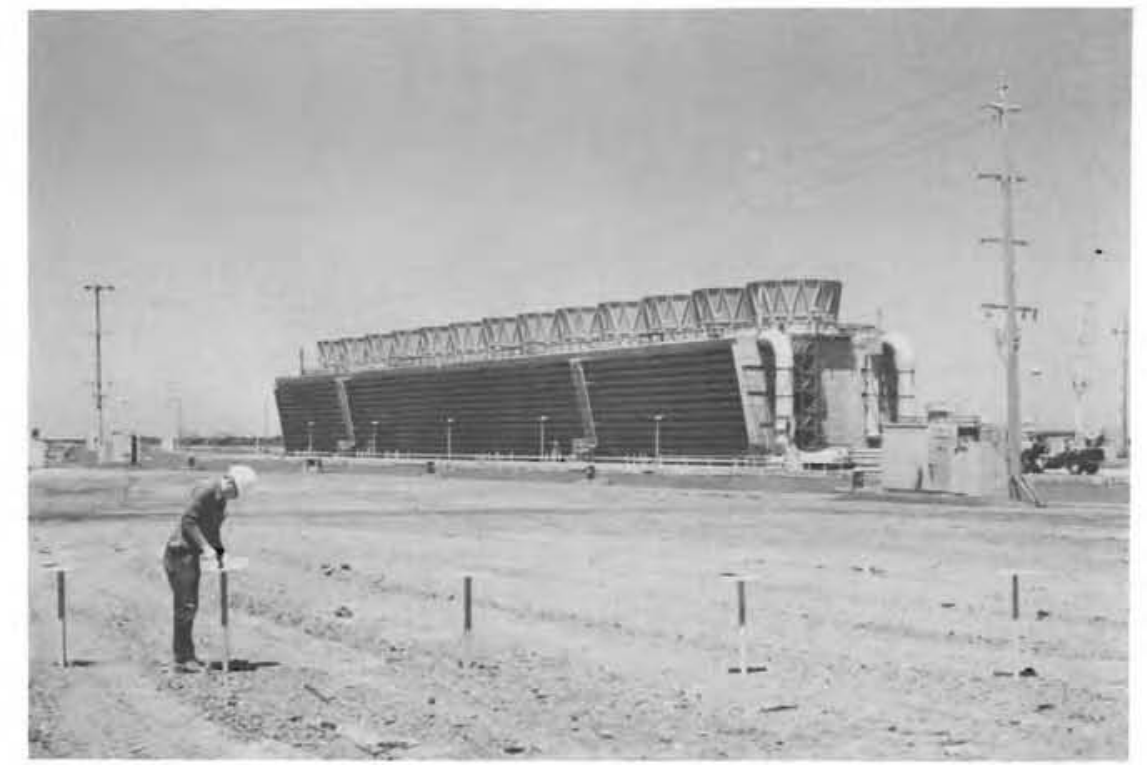

b

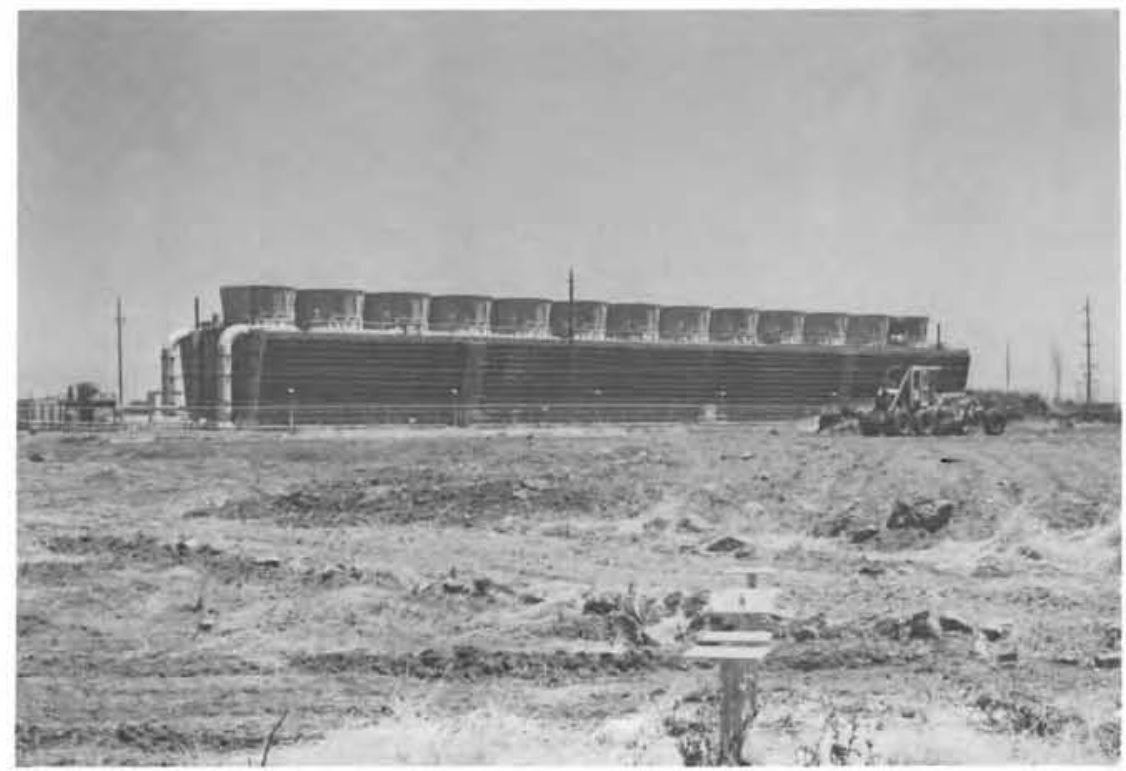

C

Figure B 5

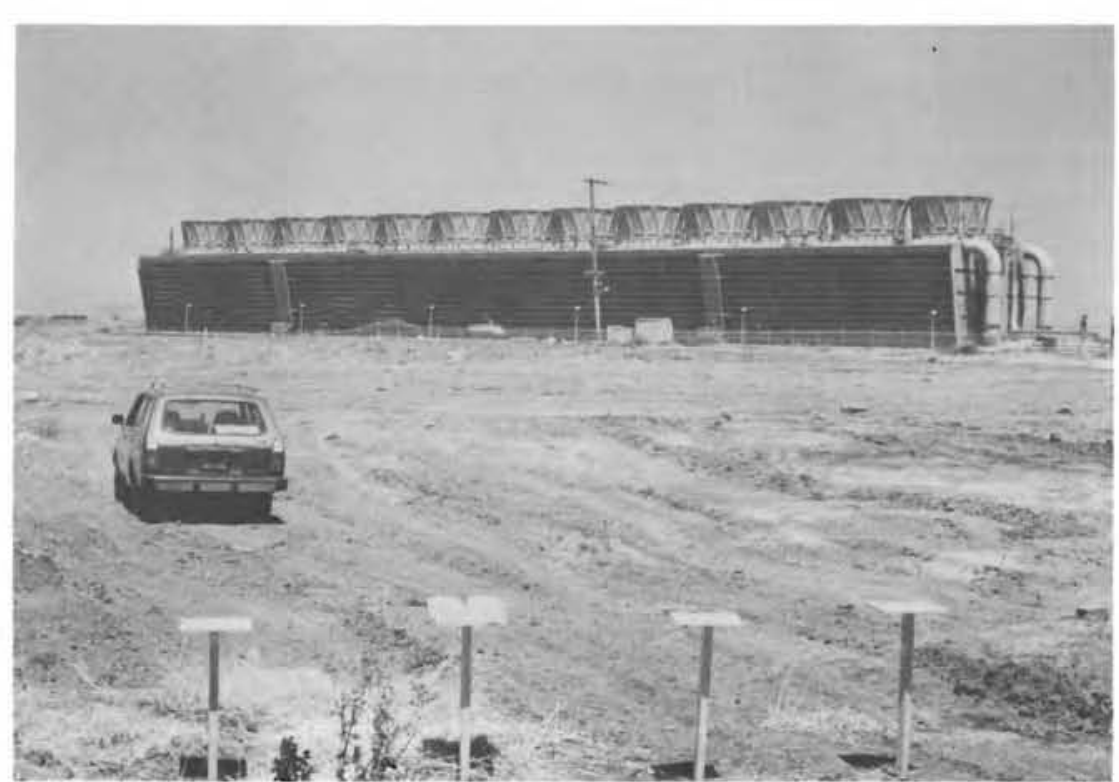




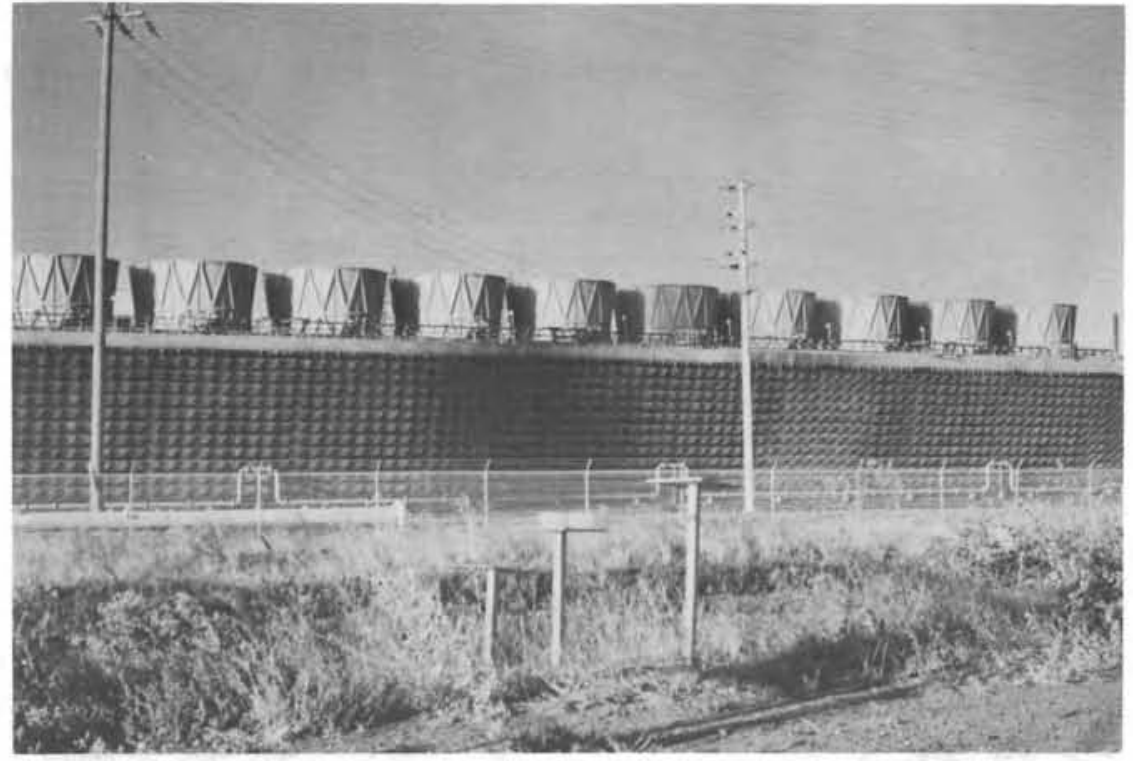

- a

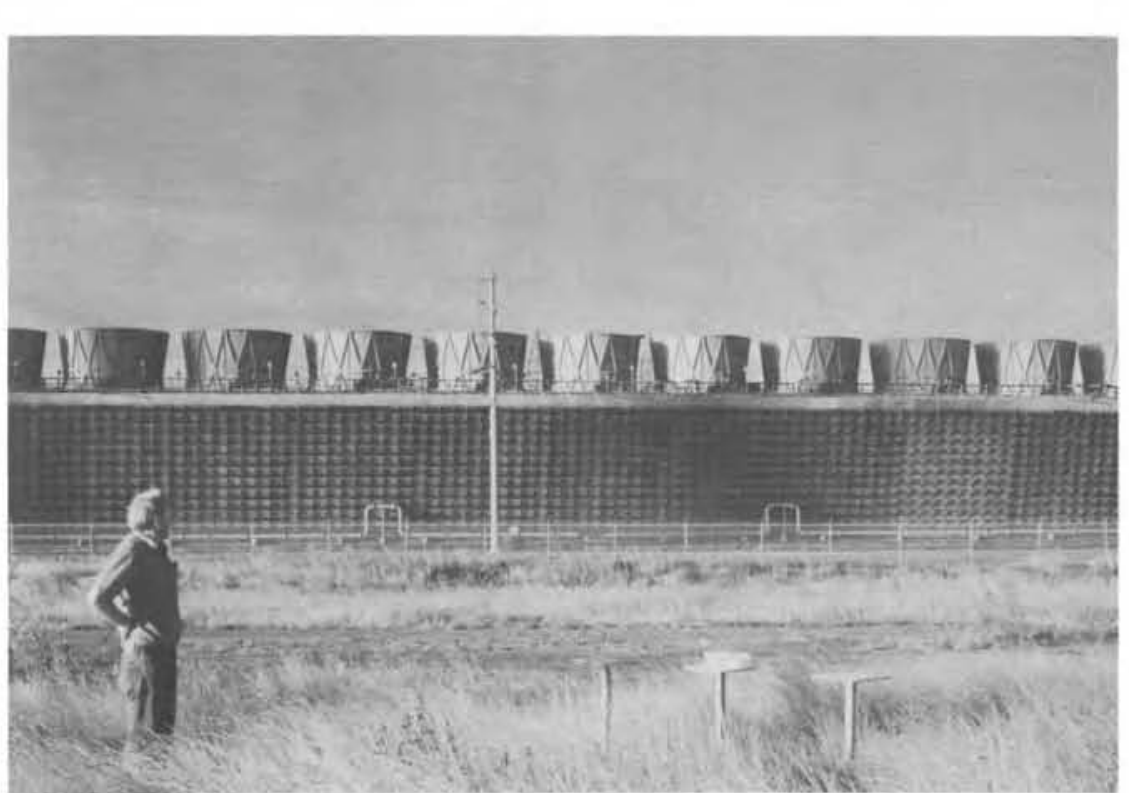

$\bar{C}$

Figure B 6

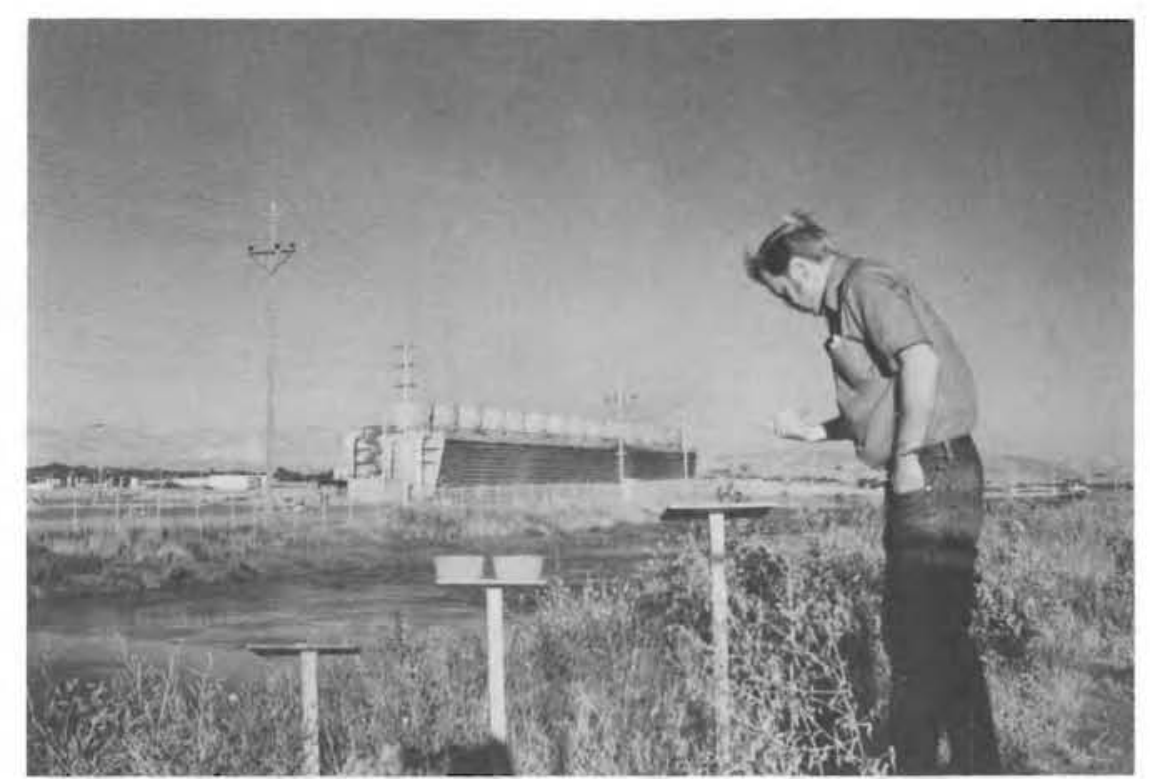

b

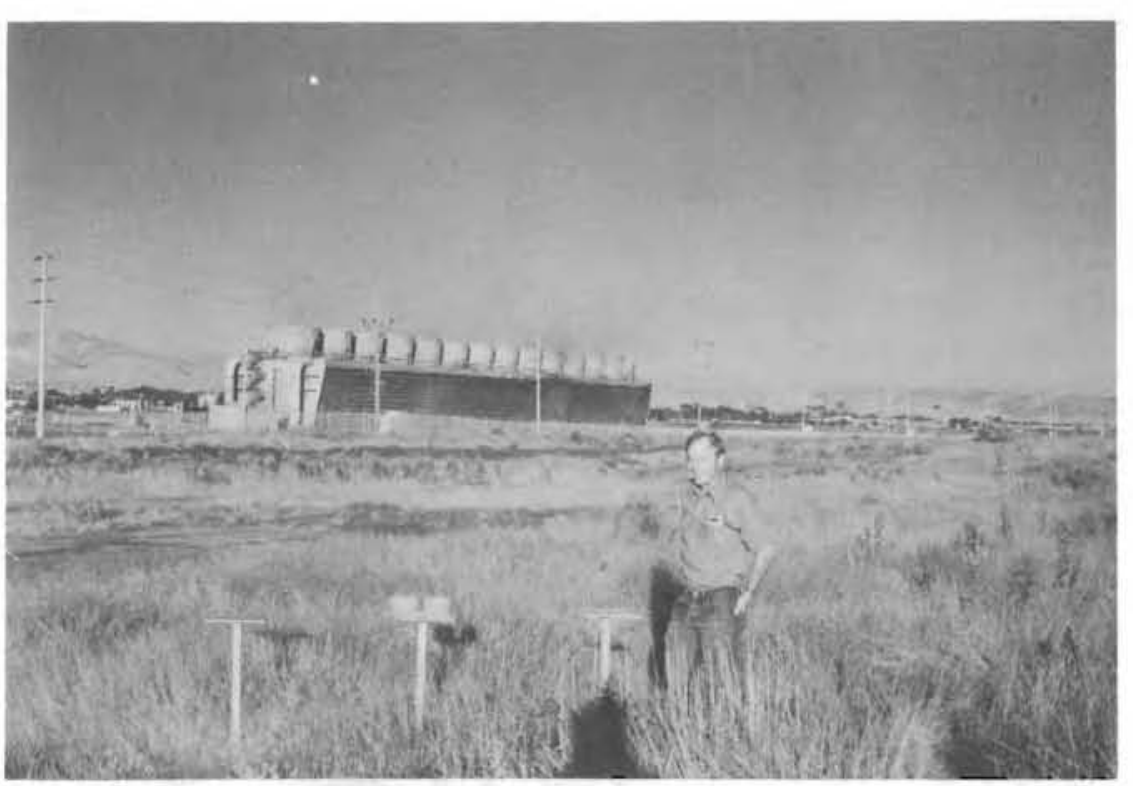

d 

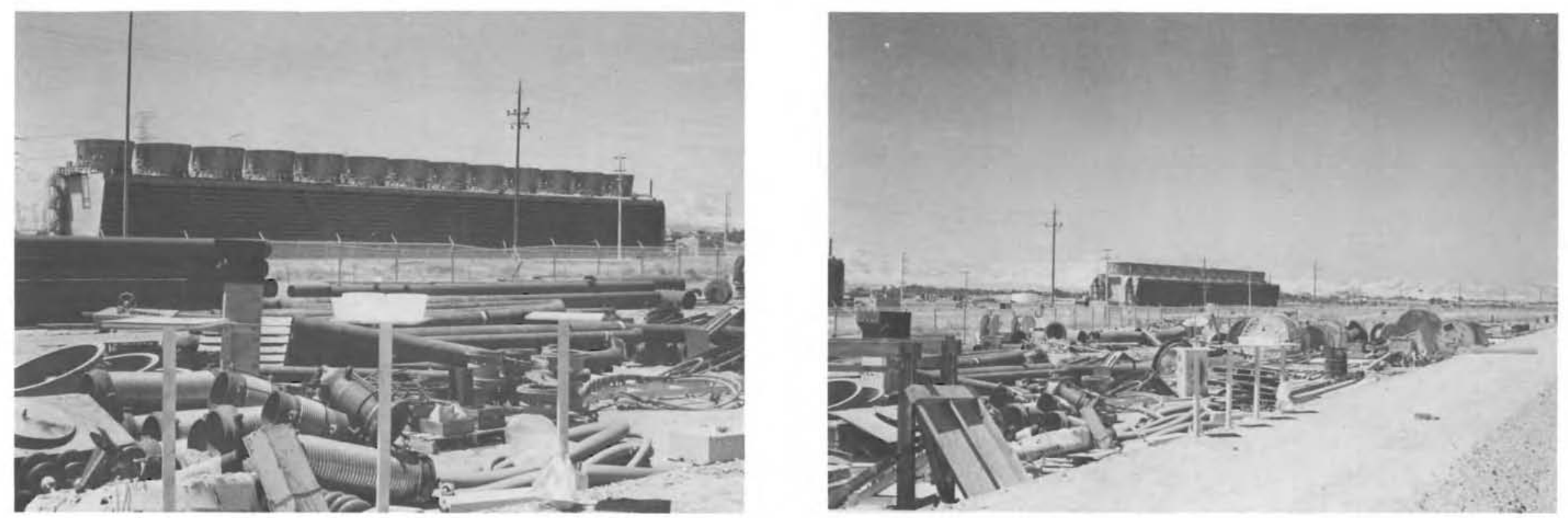

!
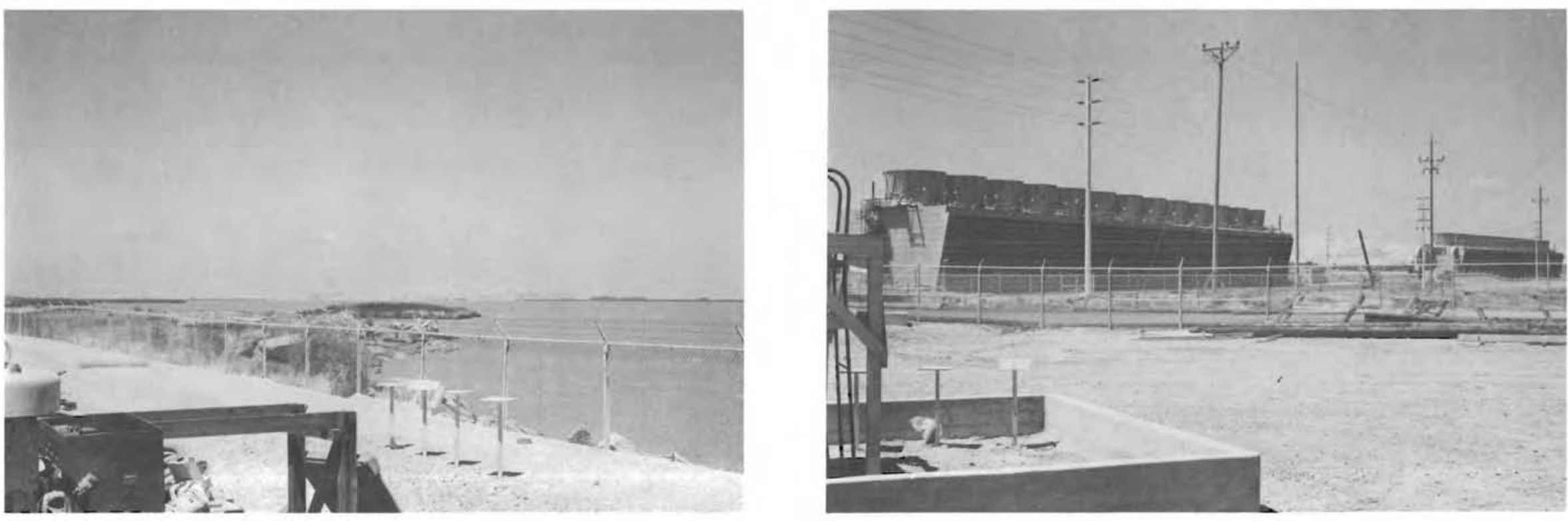

C

d

Figure B 7 

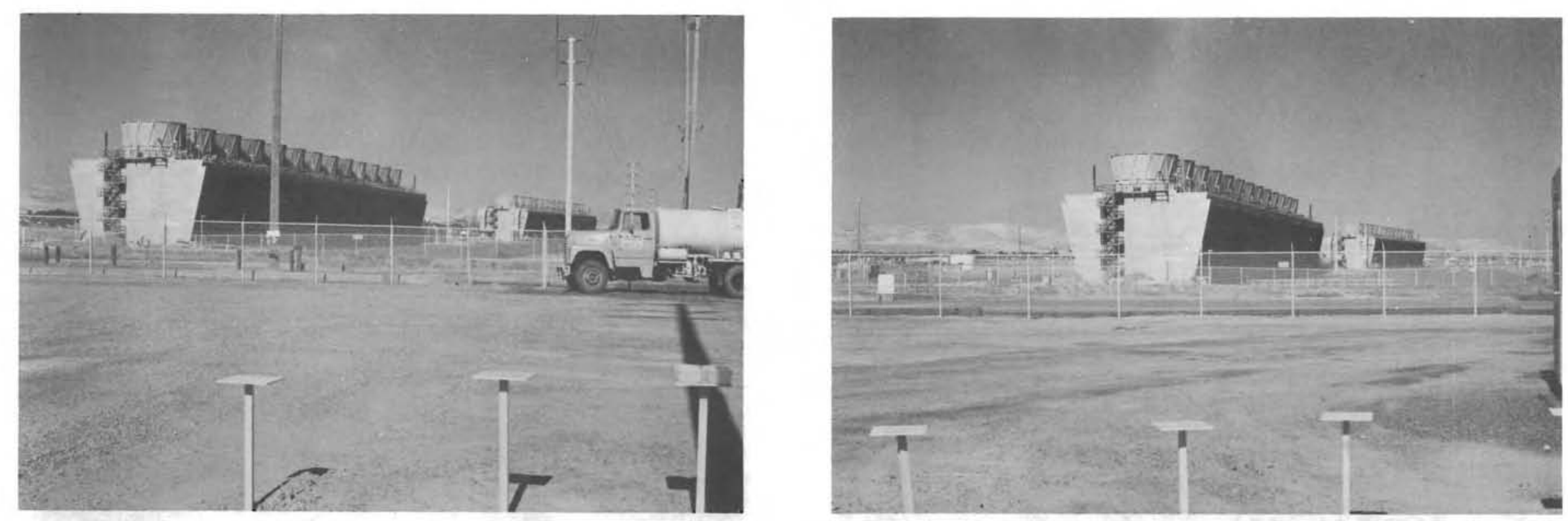

$\stackrel{1}{=}$

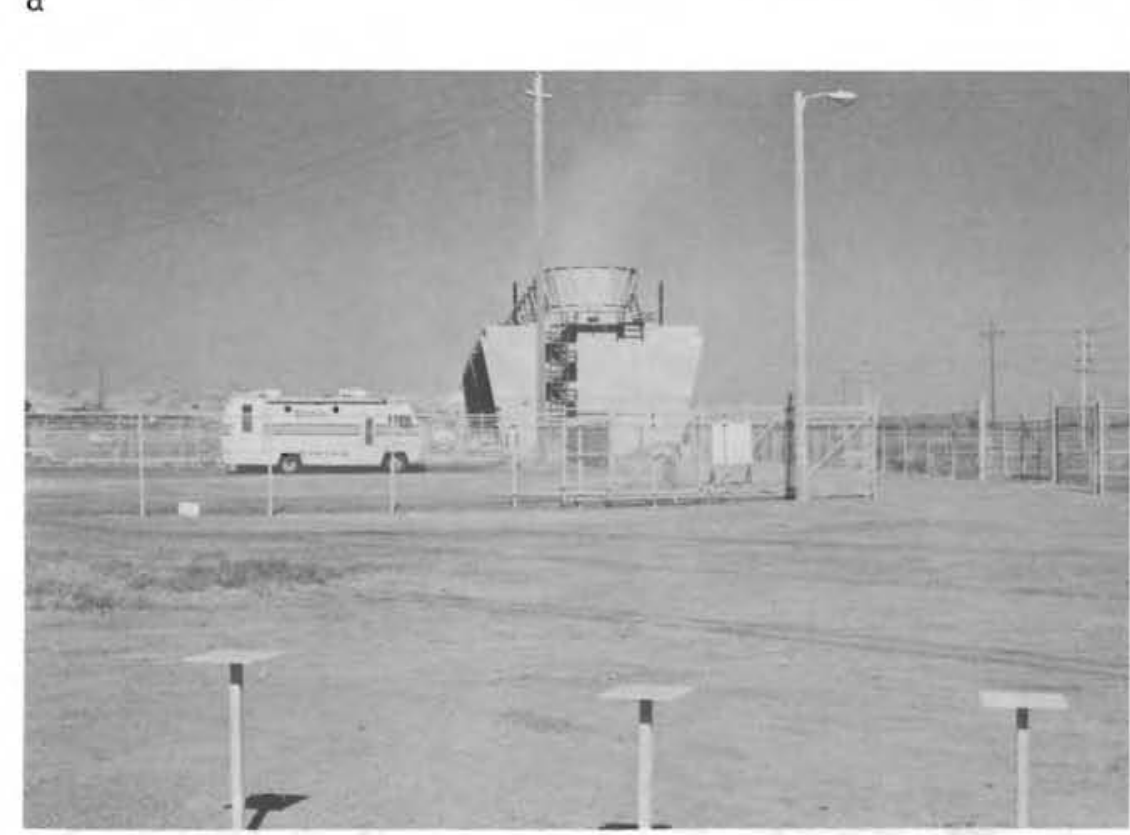

b

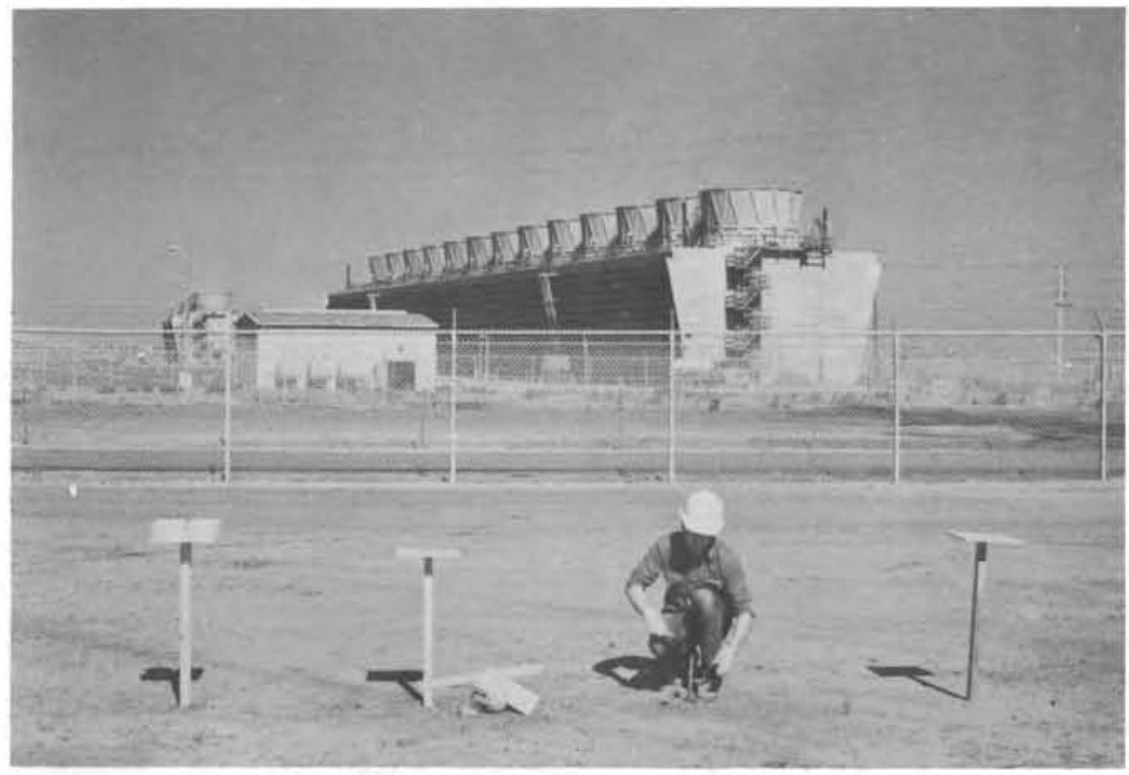

C

Figure B 8 


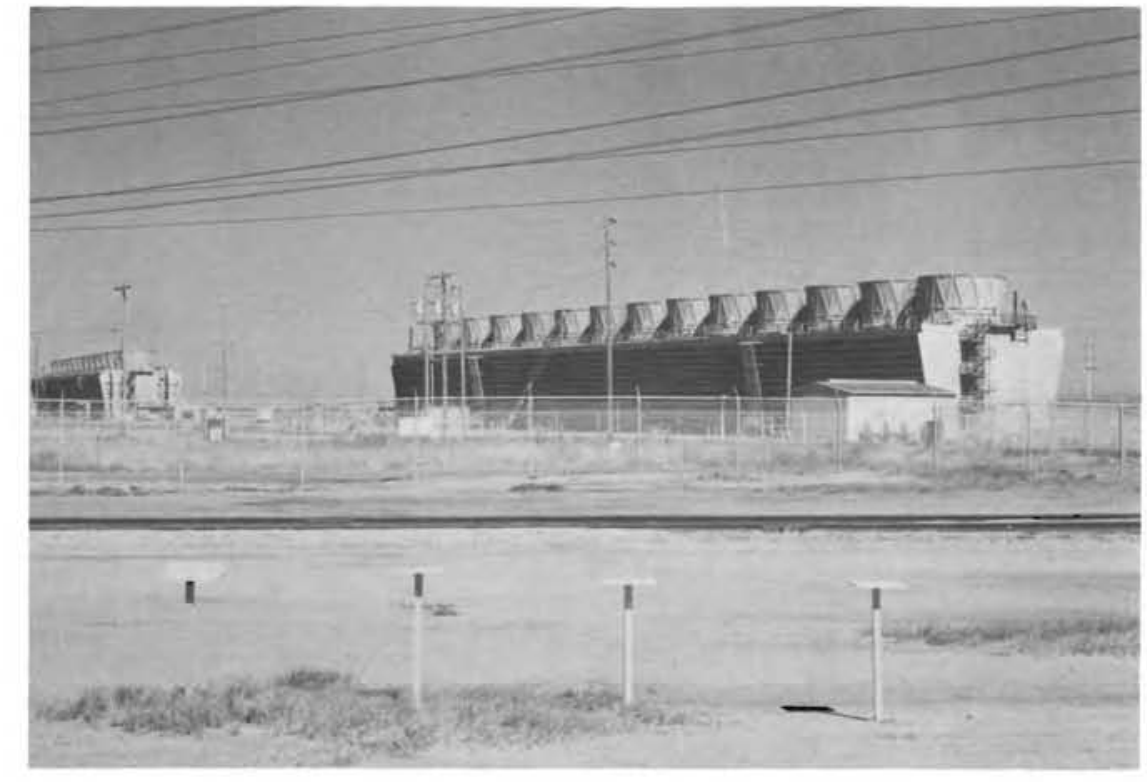

a

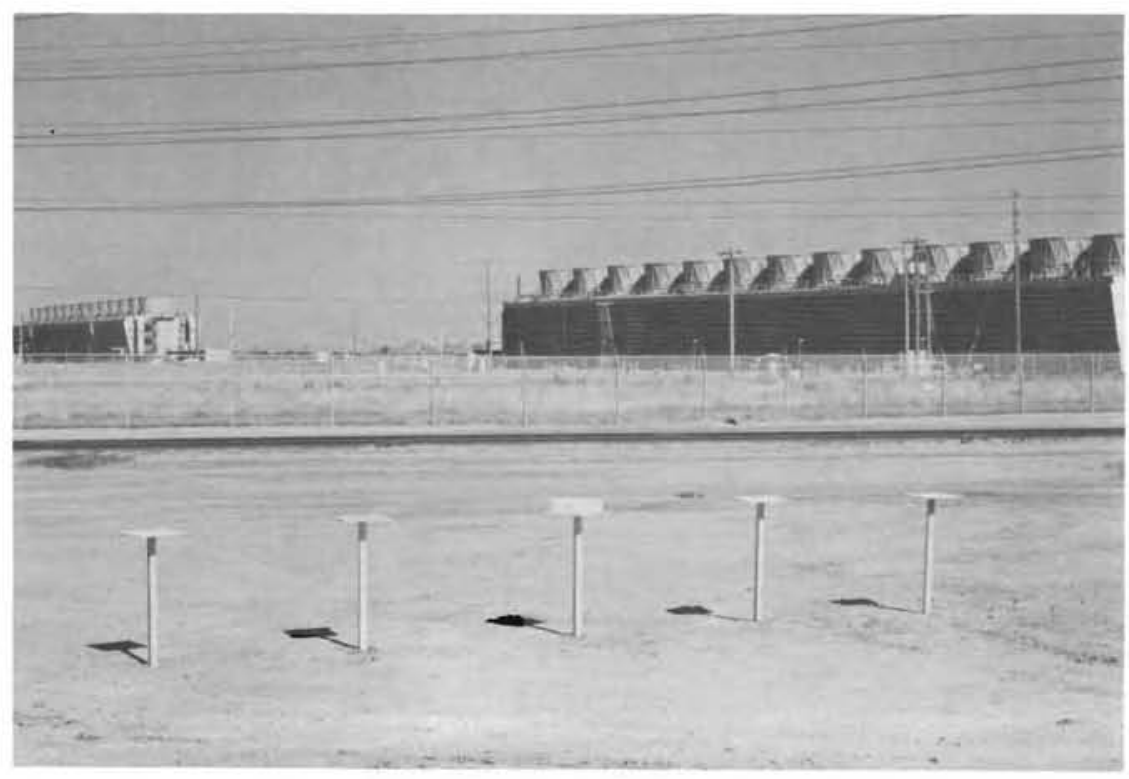

C

Figure B 9

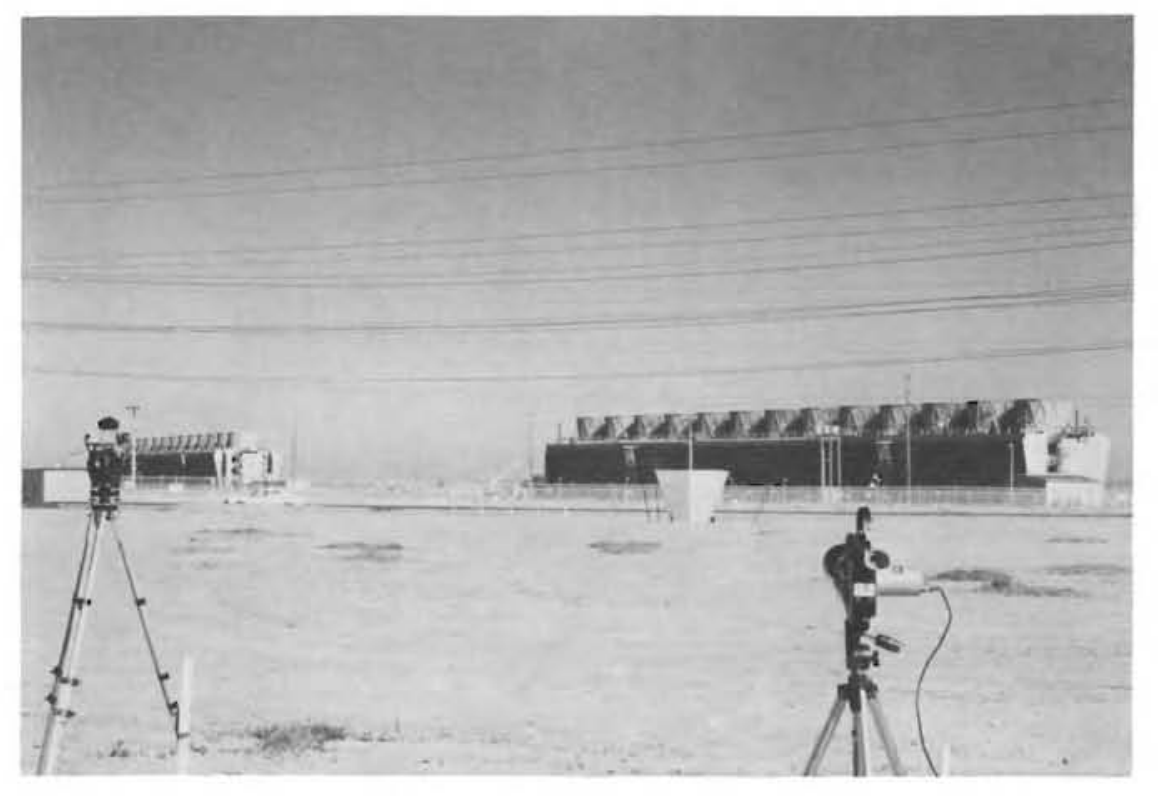

b

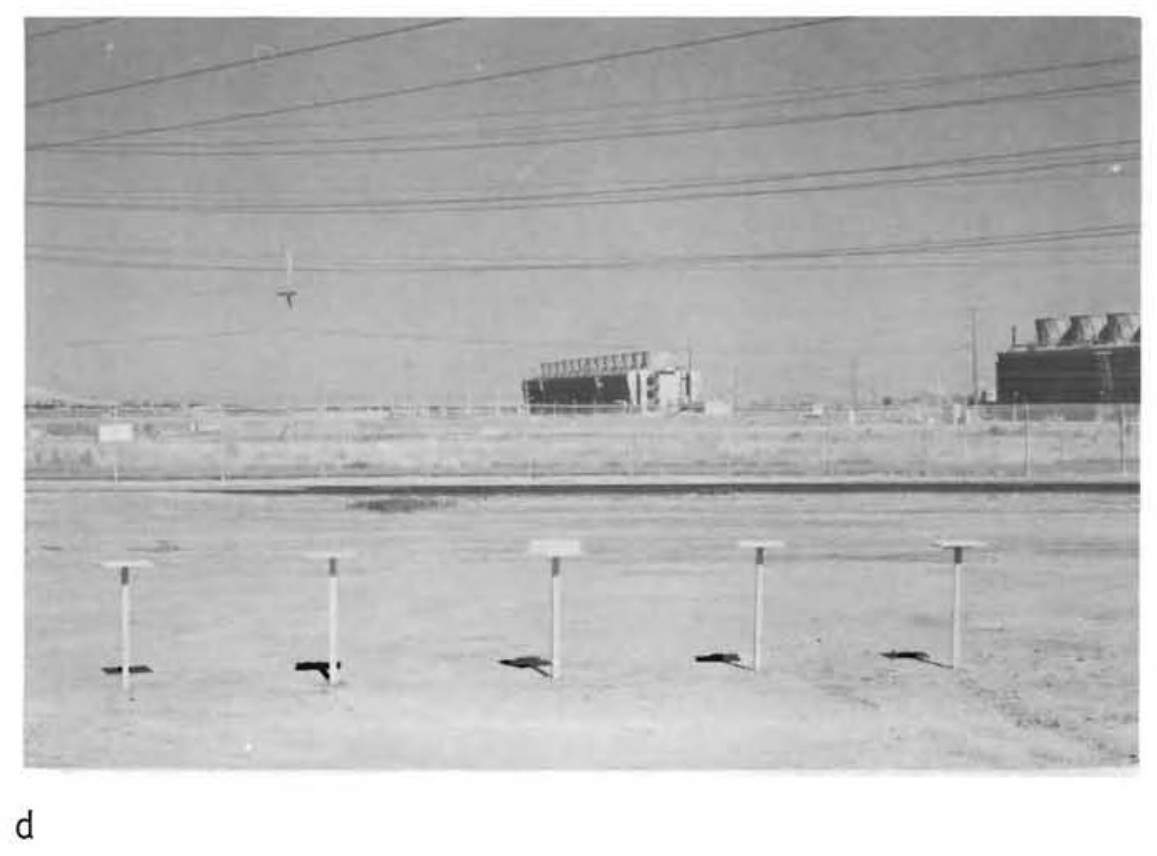




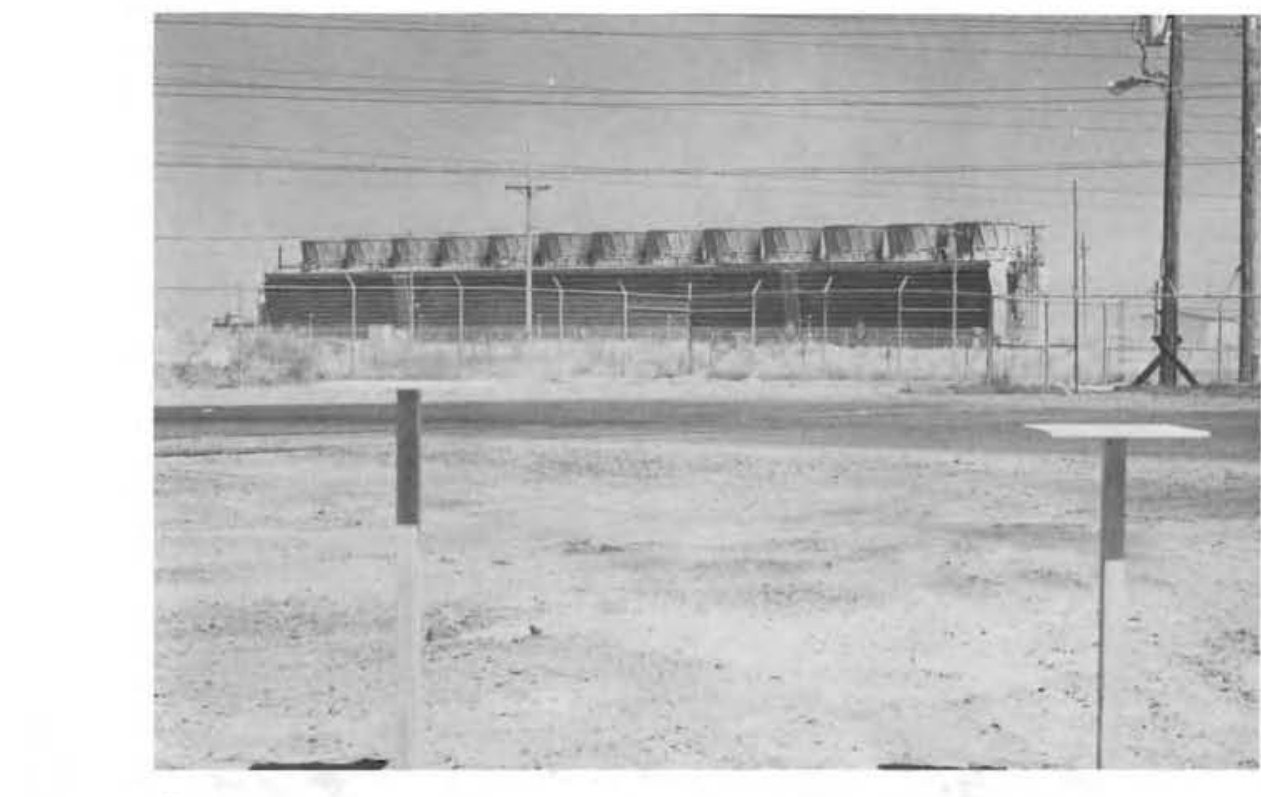

$\frac{\infty}{\omega}$

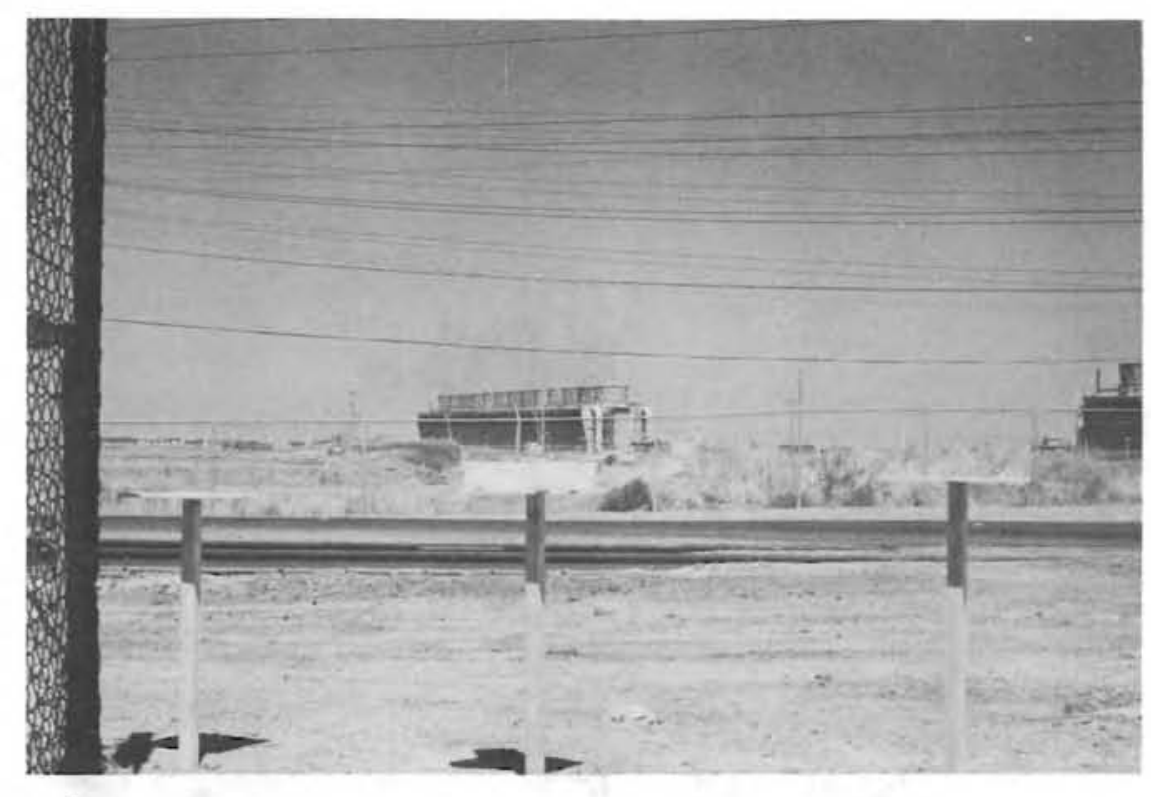

b
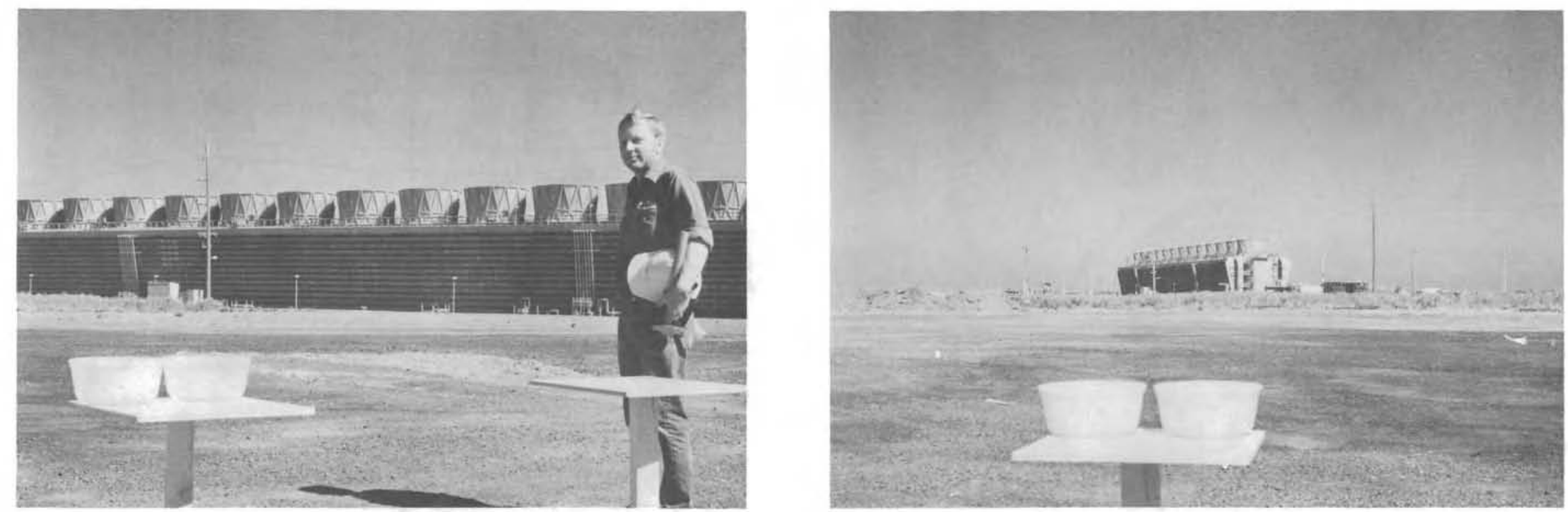

c

Figure B 10 

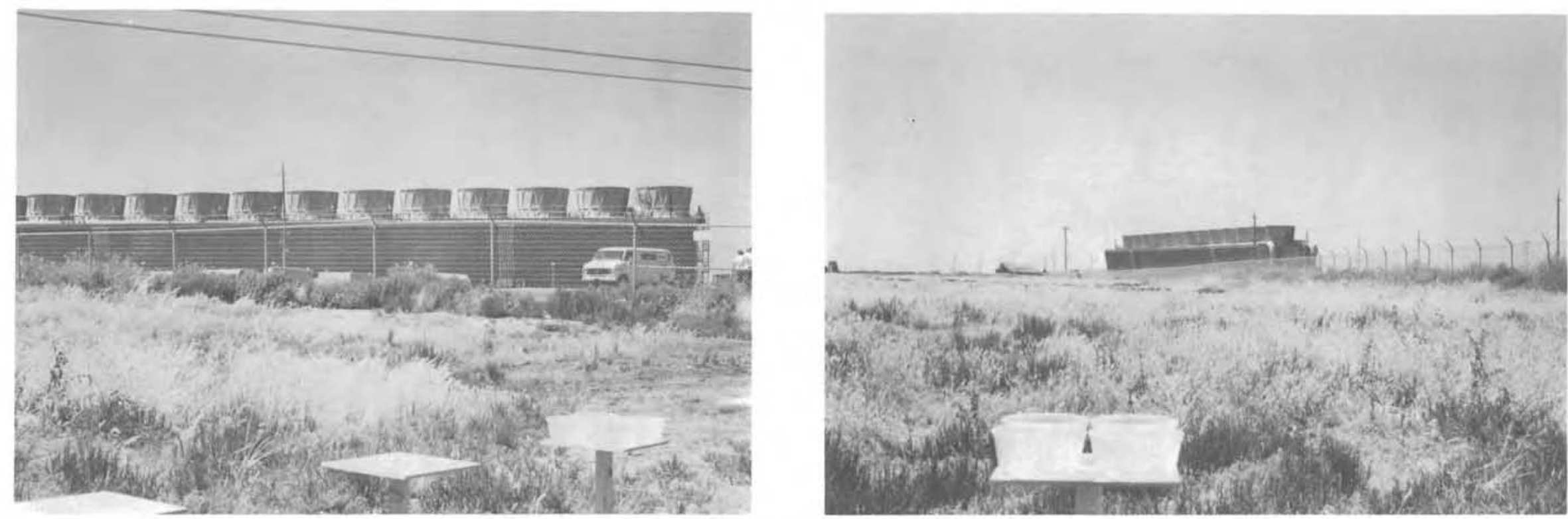

$\frac{1}{\square}$

a

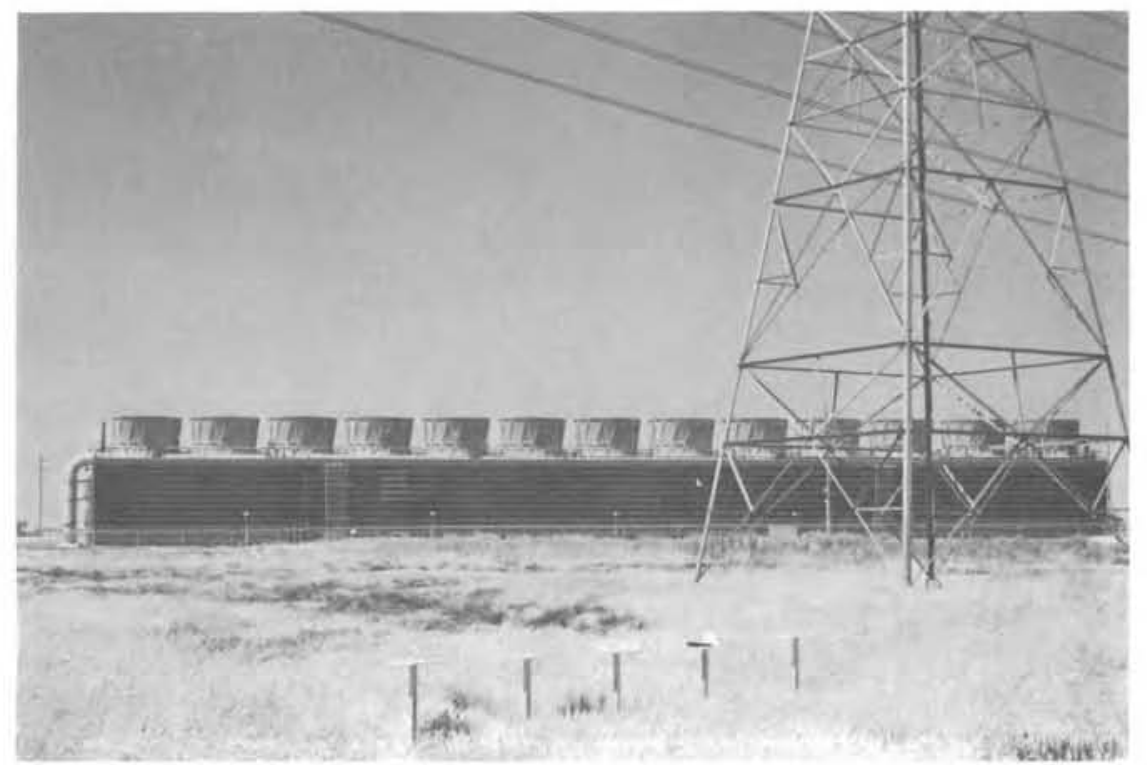

b

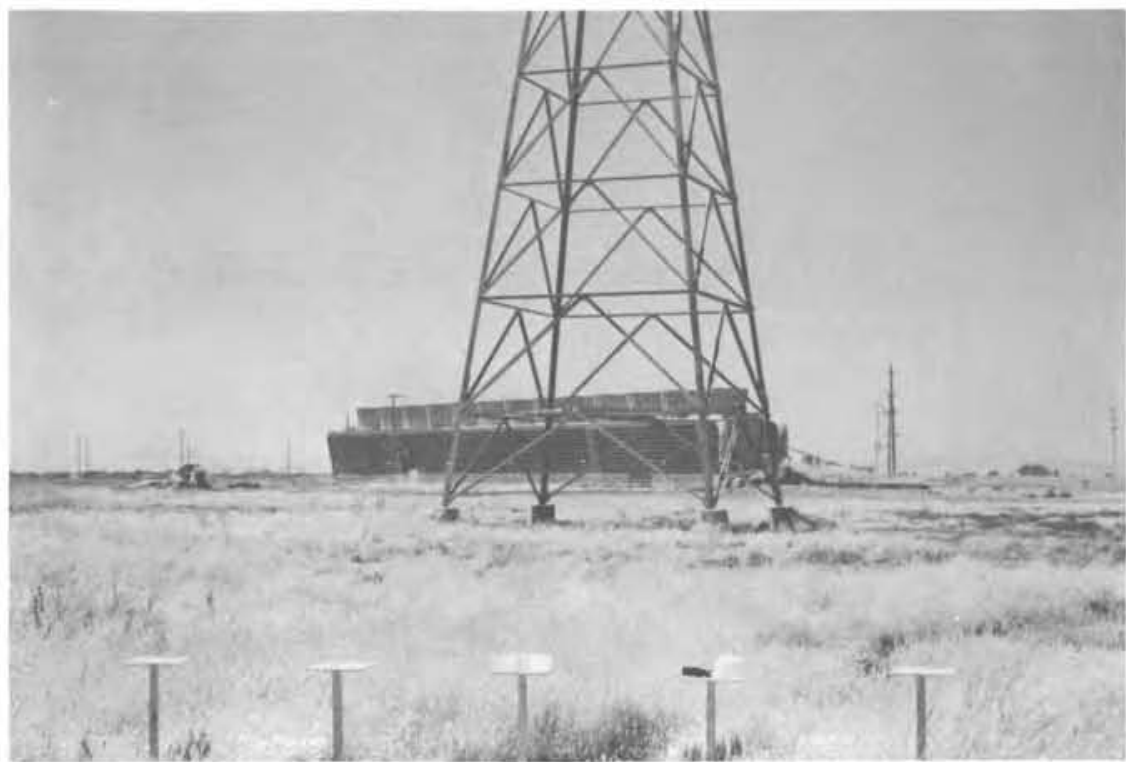

d

Figure B 11 

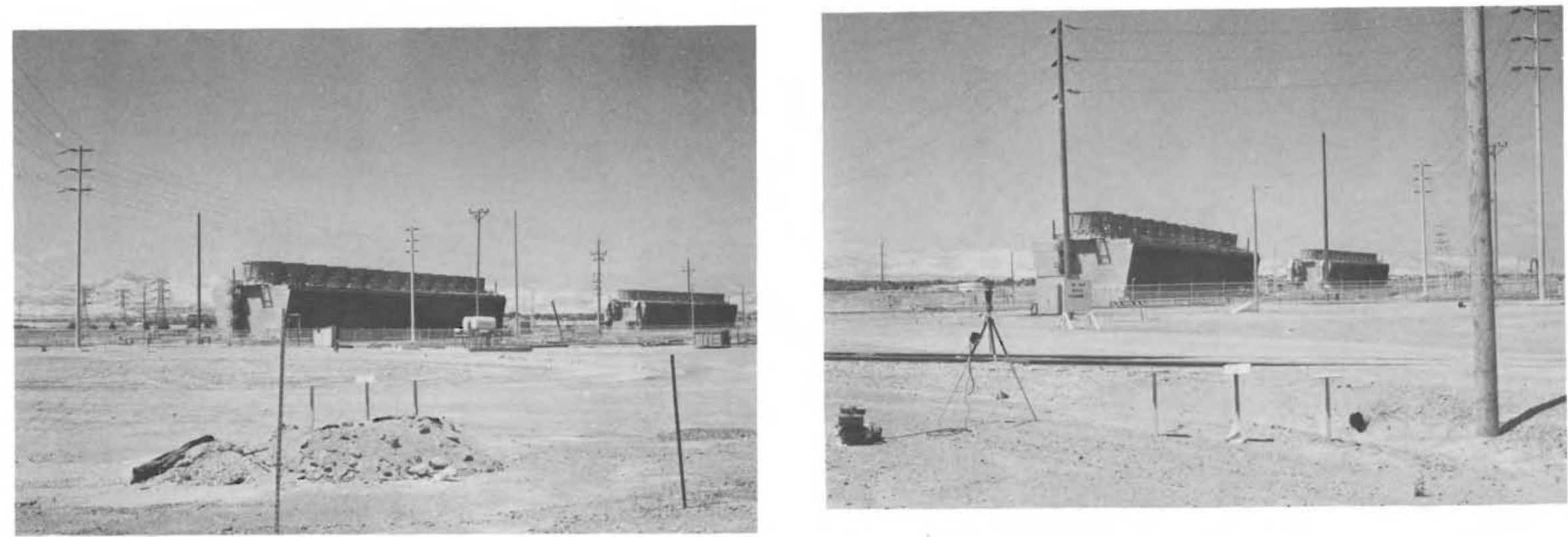

$\frac{1}{v}$

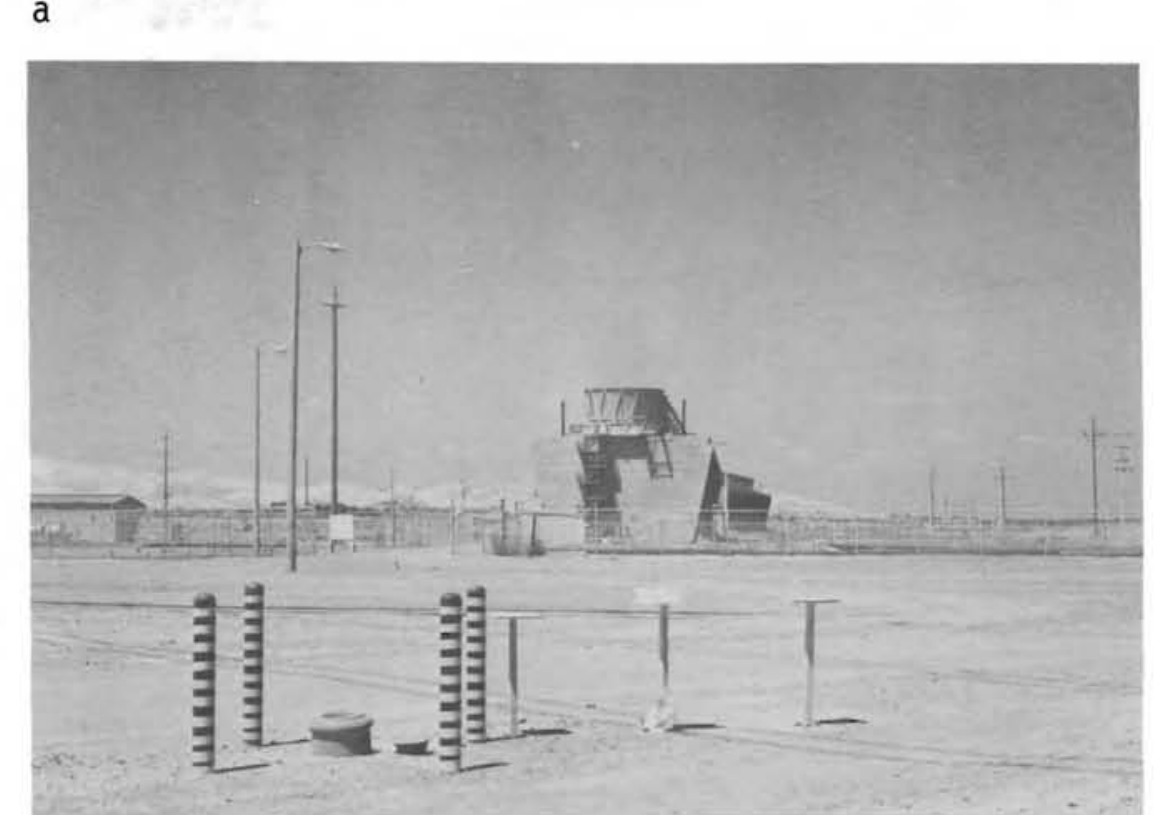

b

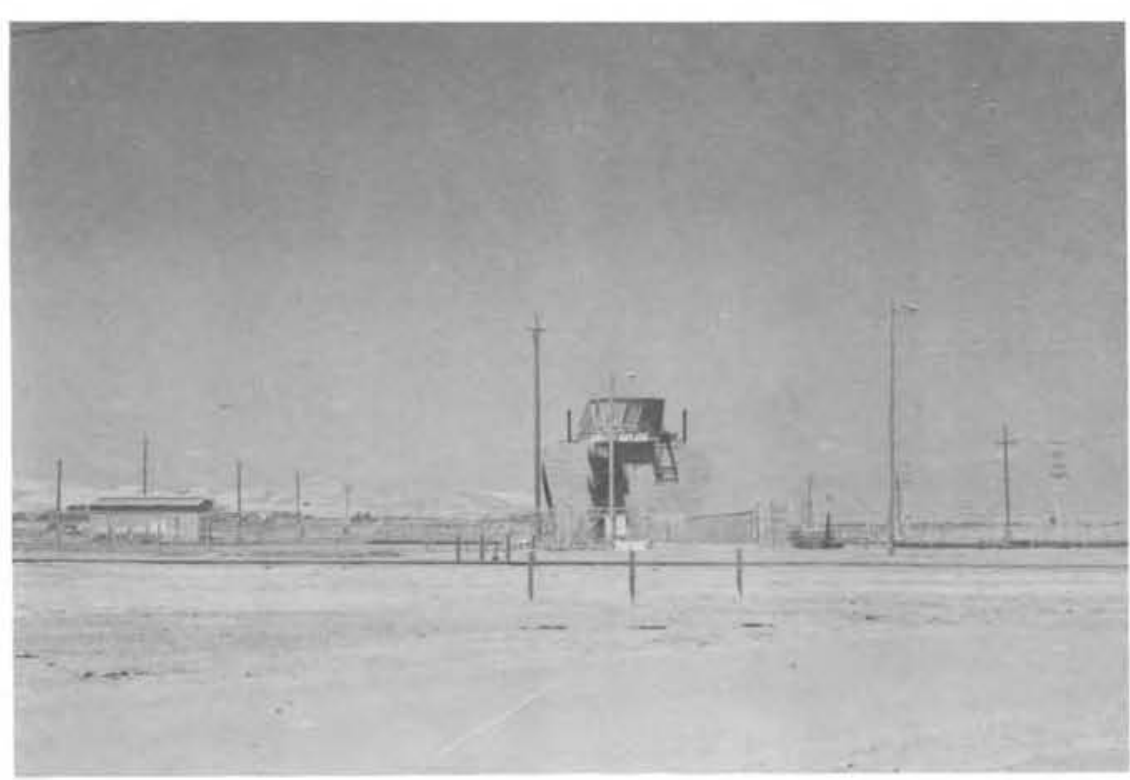

Figure B 12 


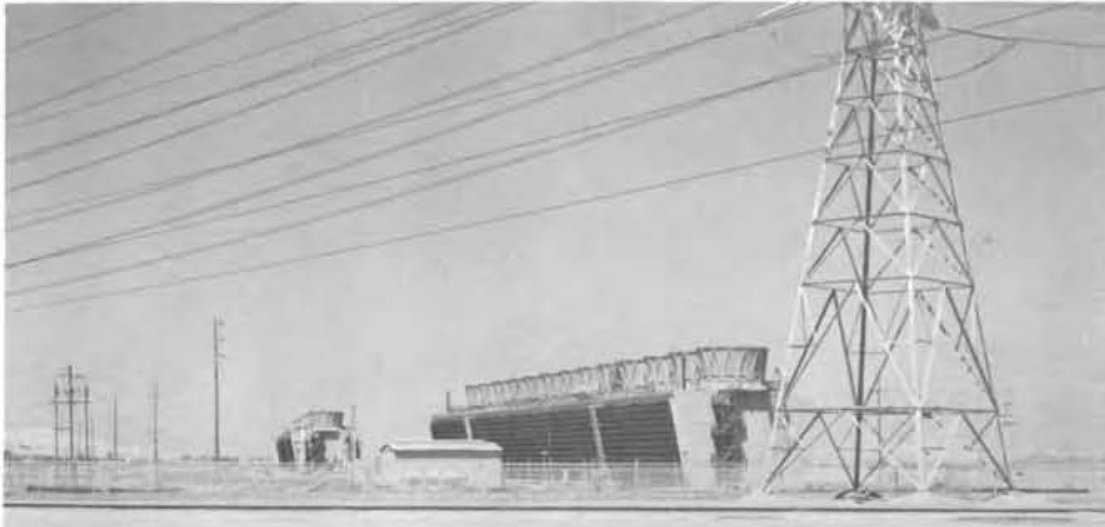

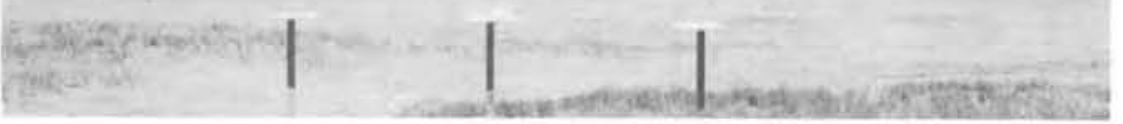

$\frac{\infty}{\sigma}$

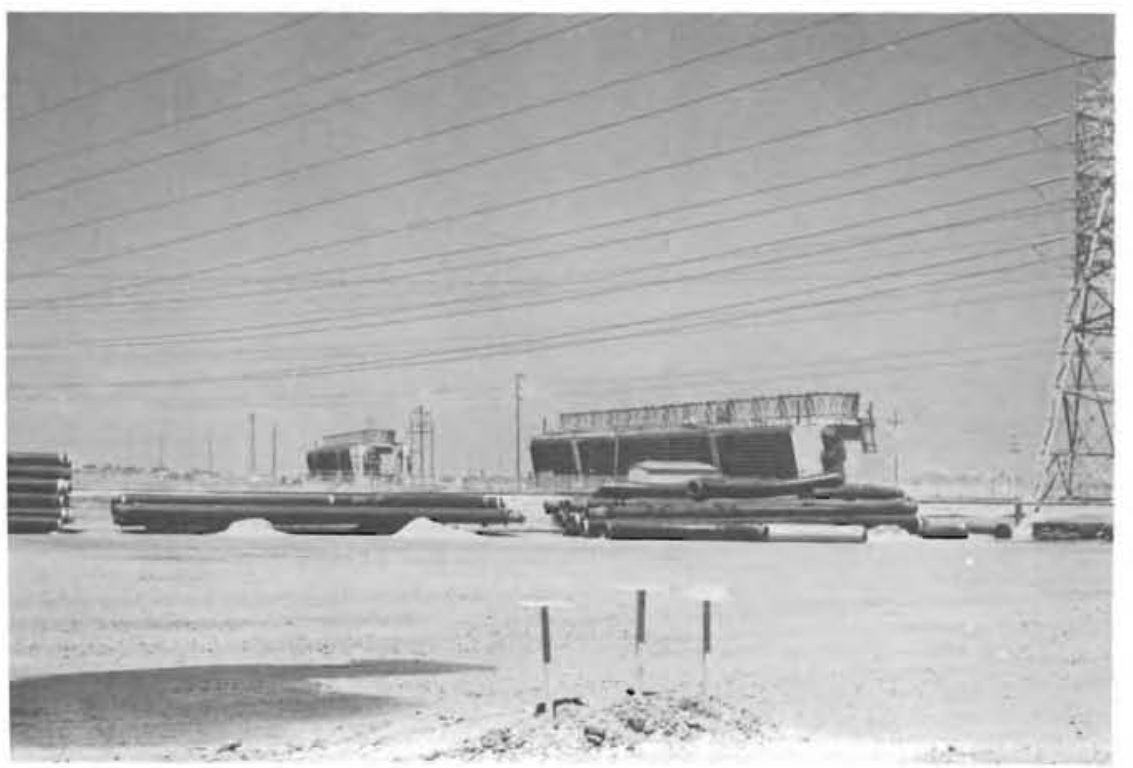

C

Figure B 13

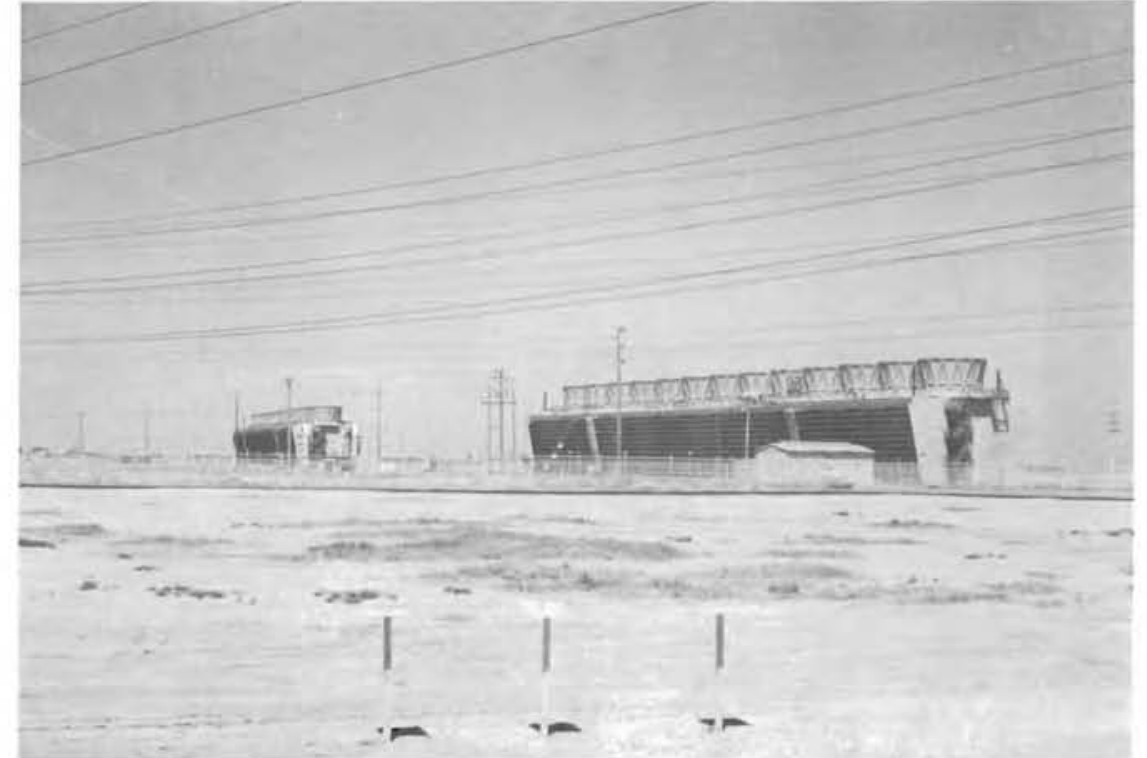

b

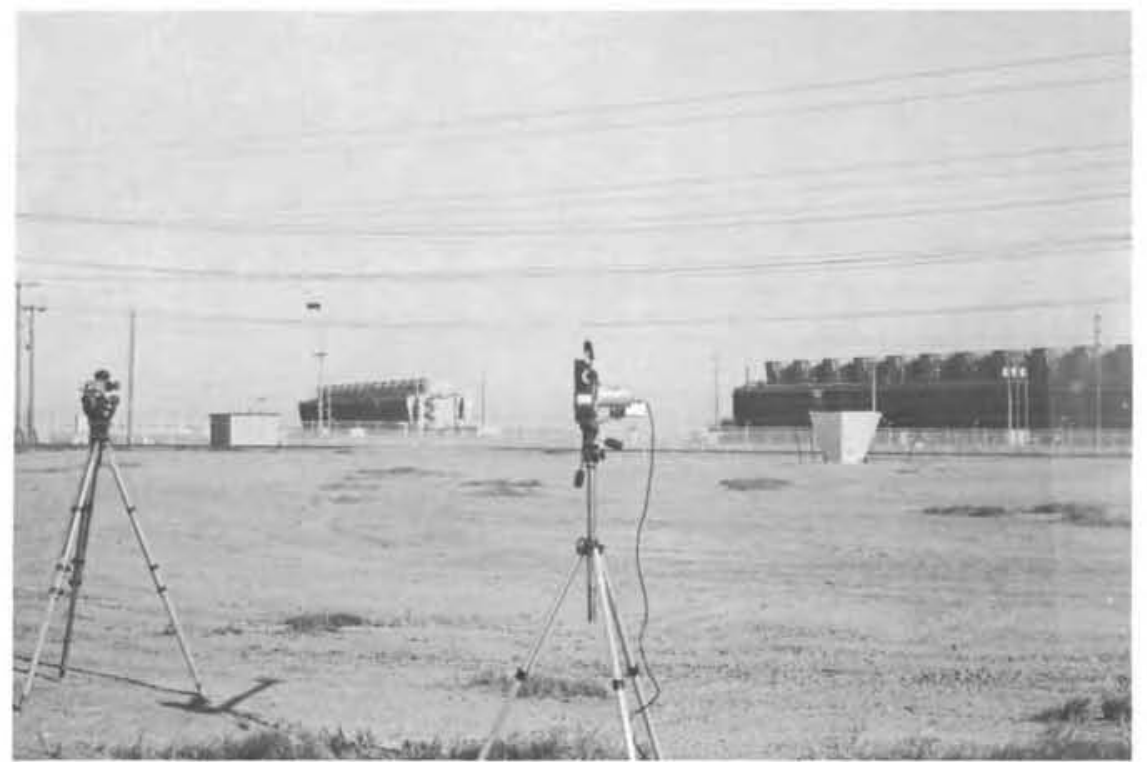

d 


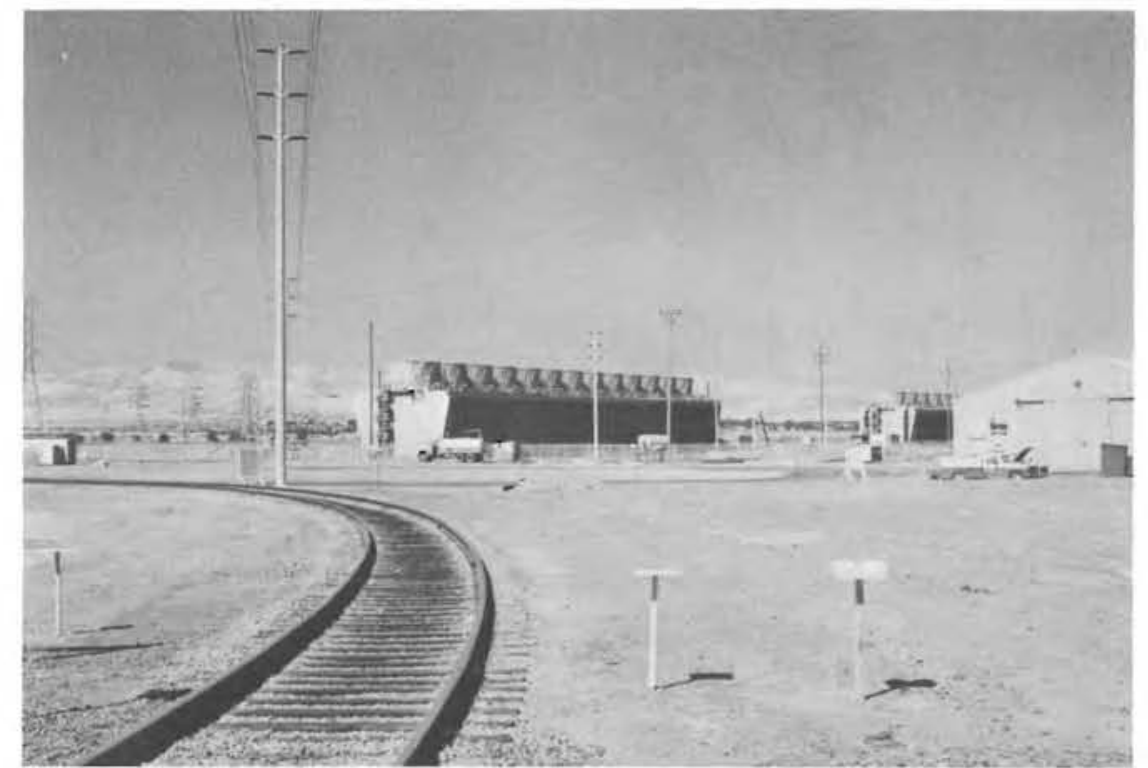

$\stackrel{\square}{\stackrel{1}{V}}$

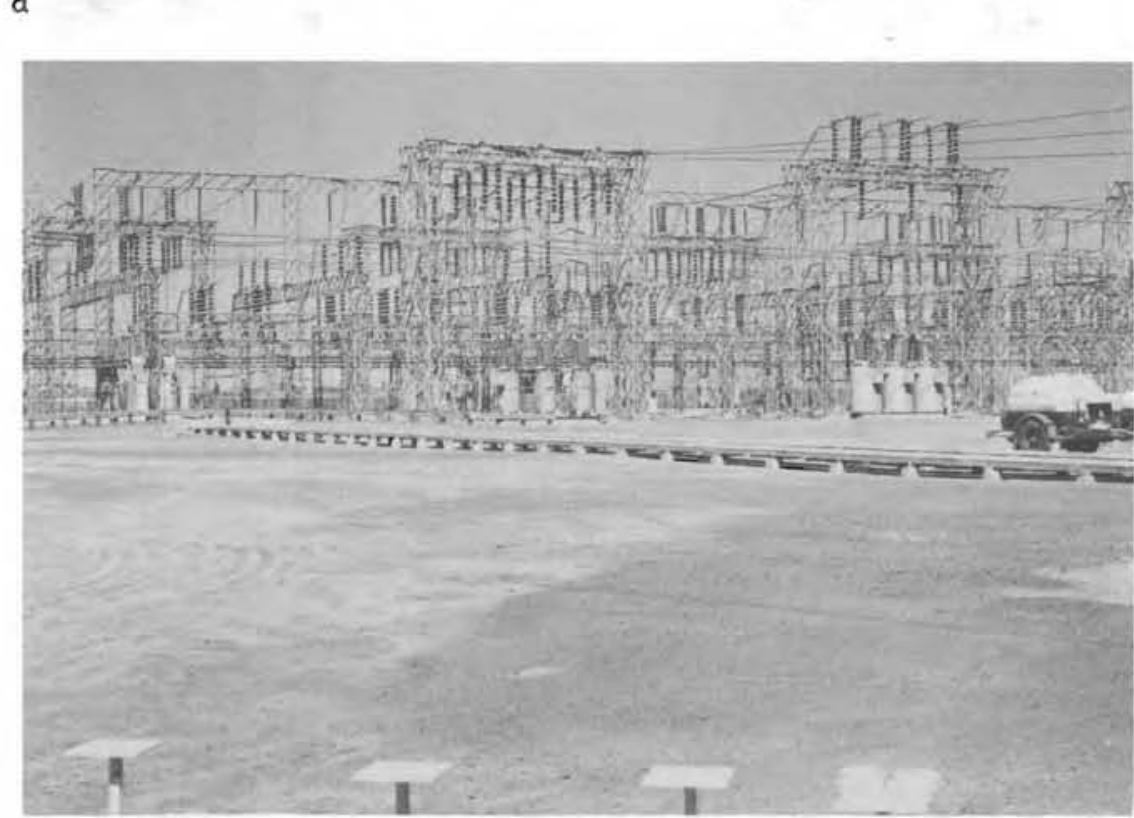

Figure $B \quad 14$

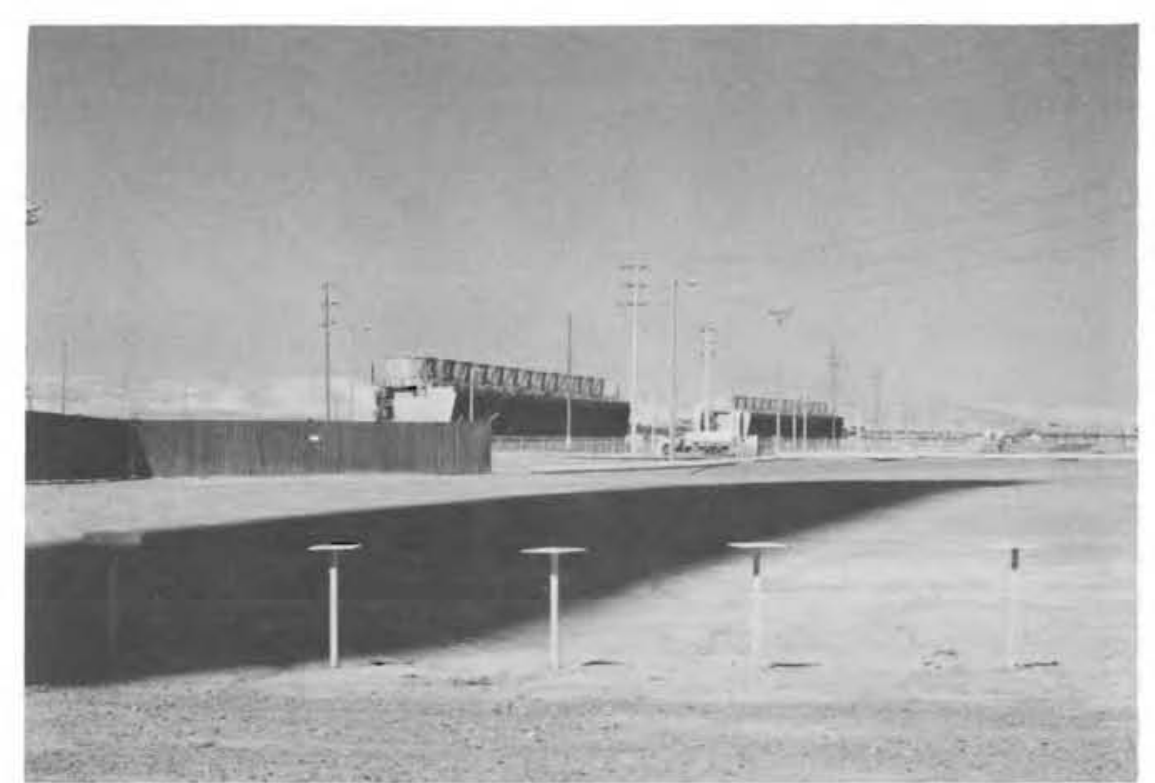

b

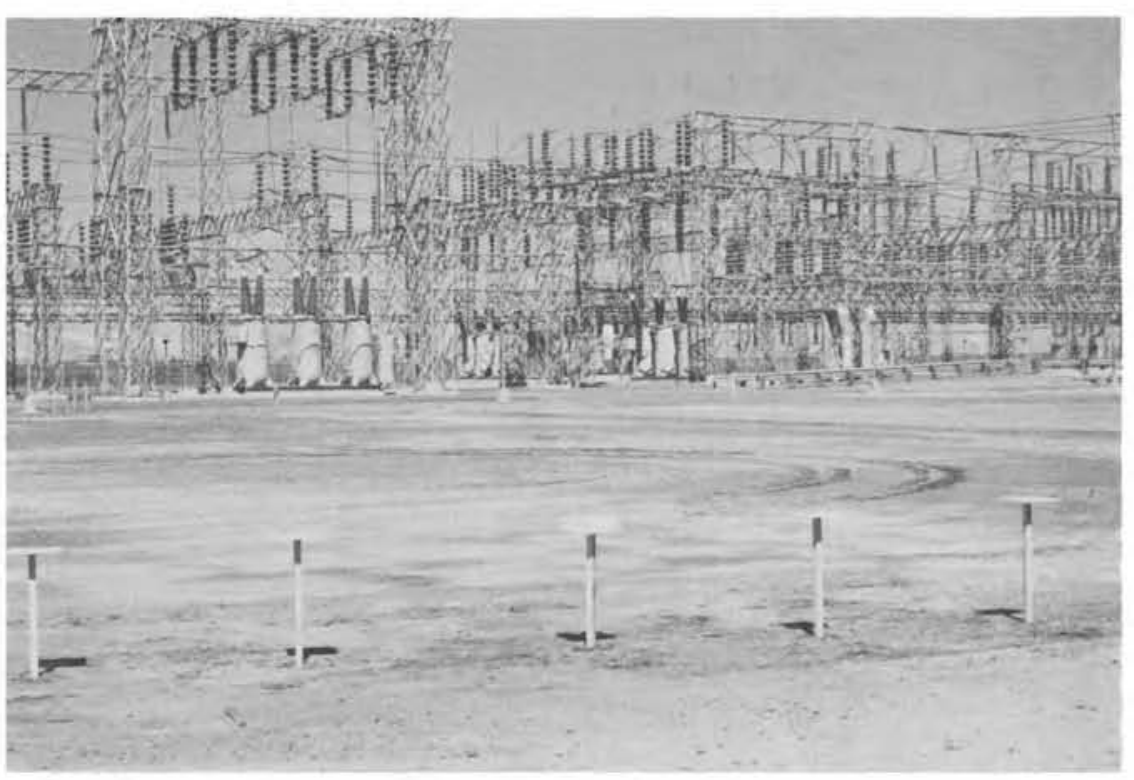

d 


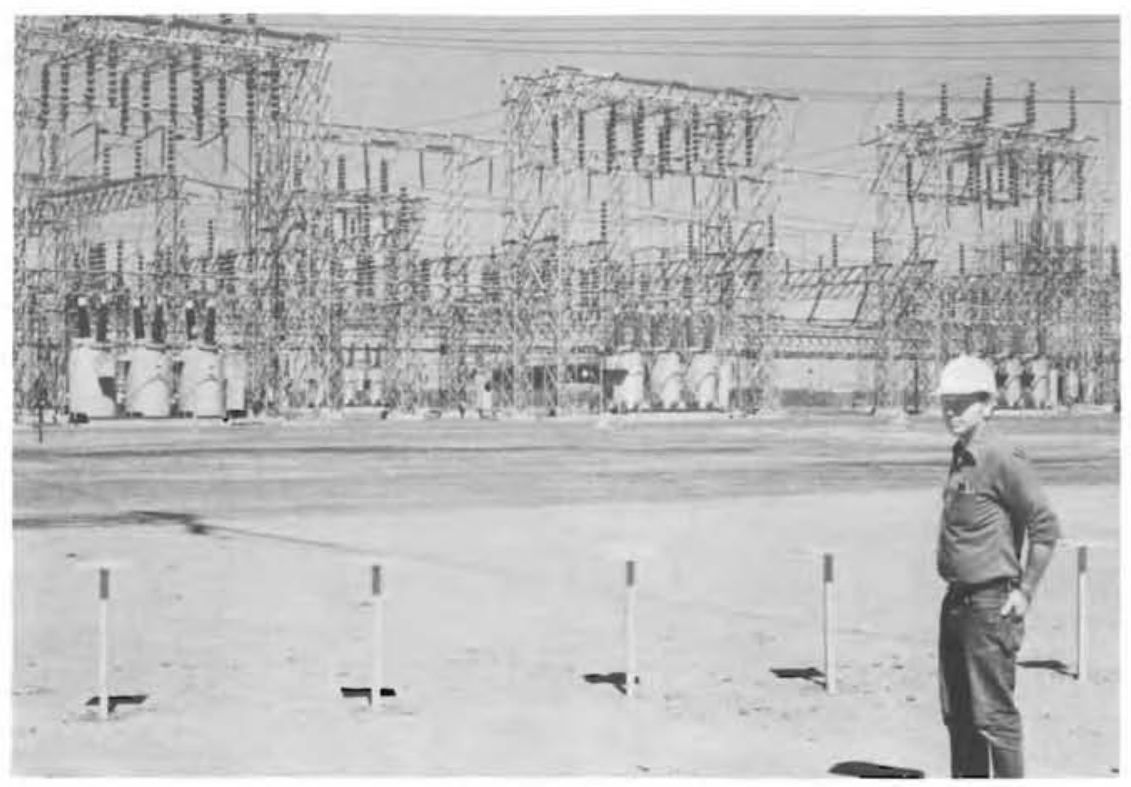

$\frac{\infty}{1}$

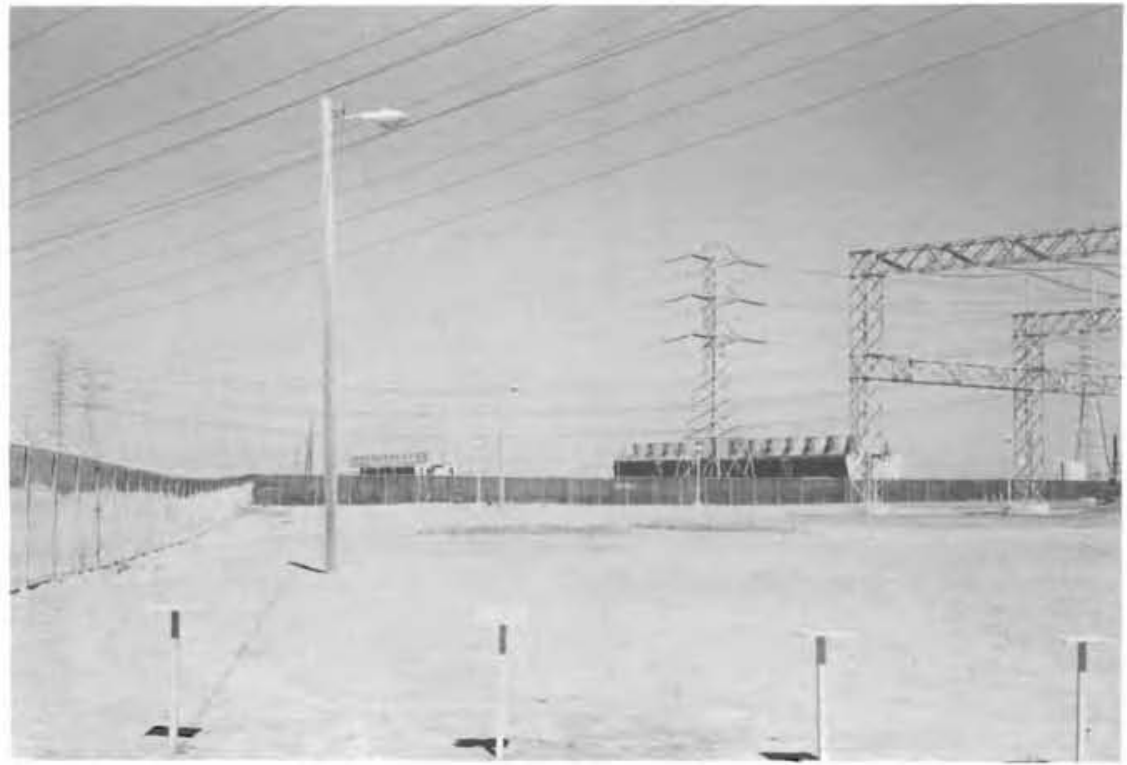

b

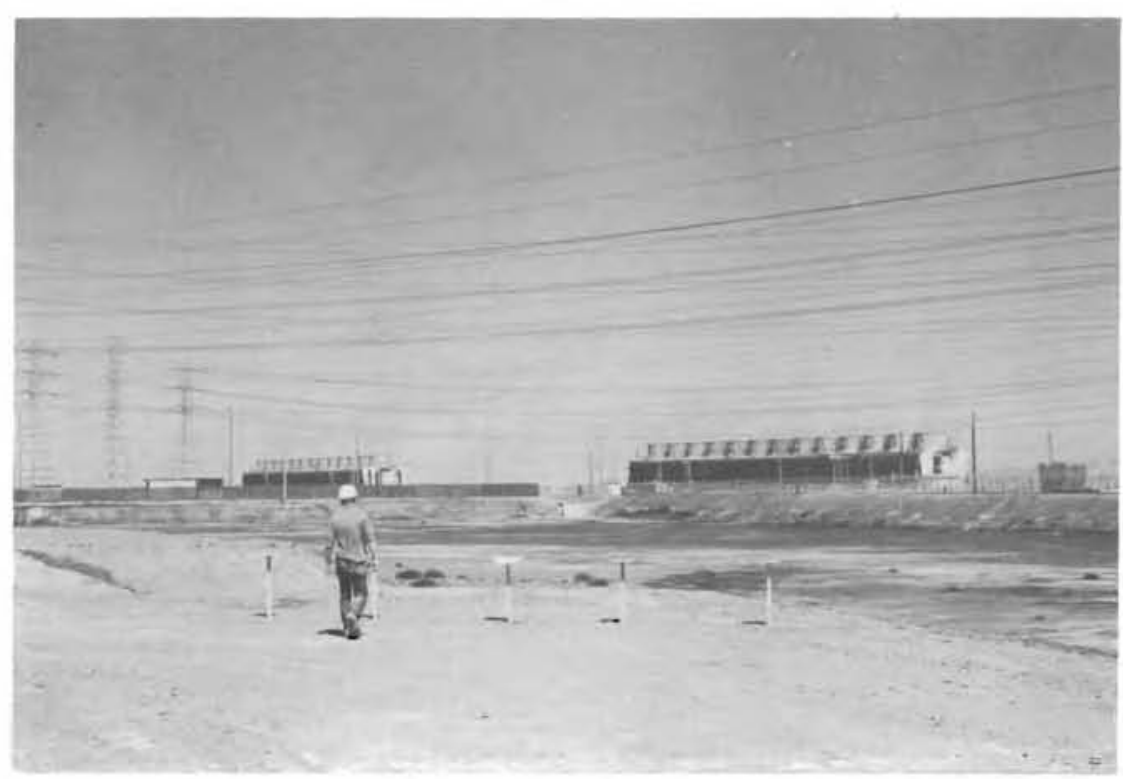

Figure B 15

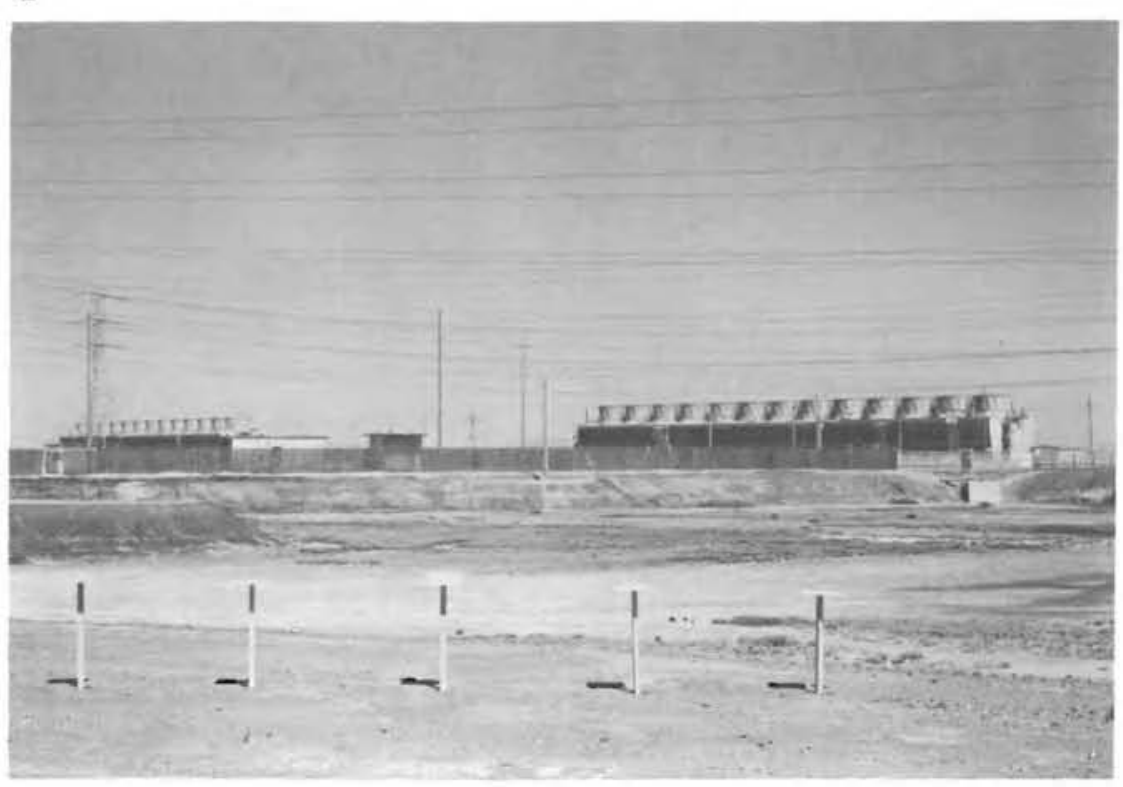

d 

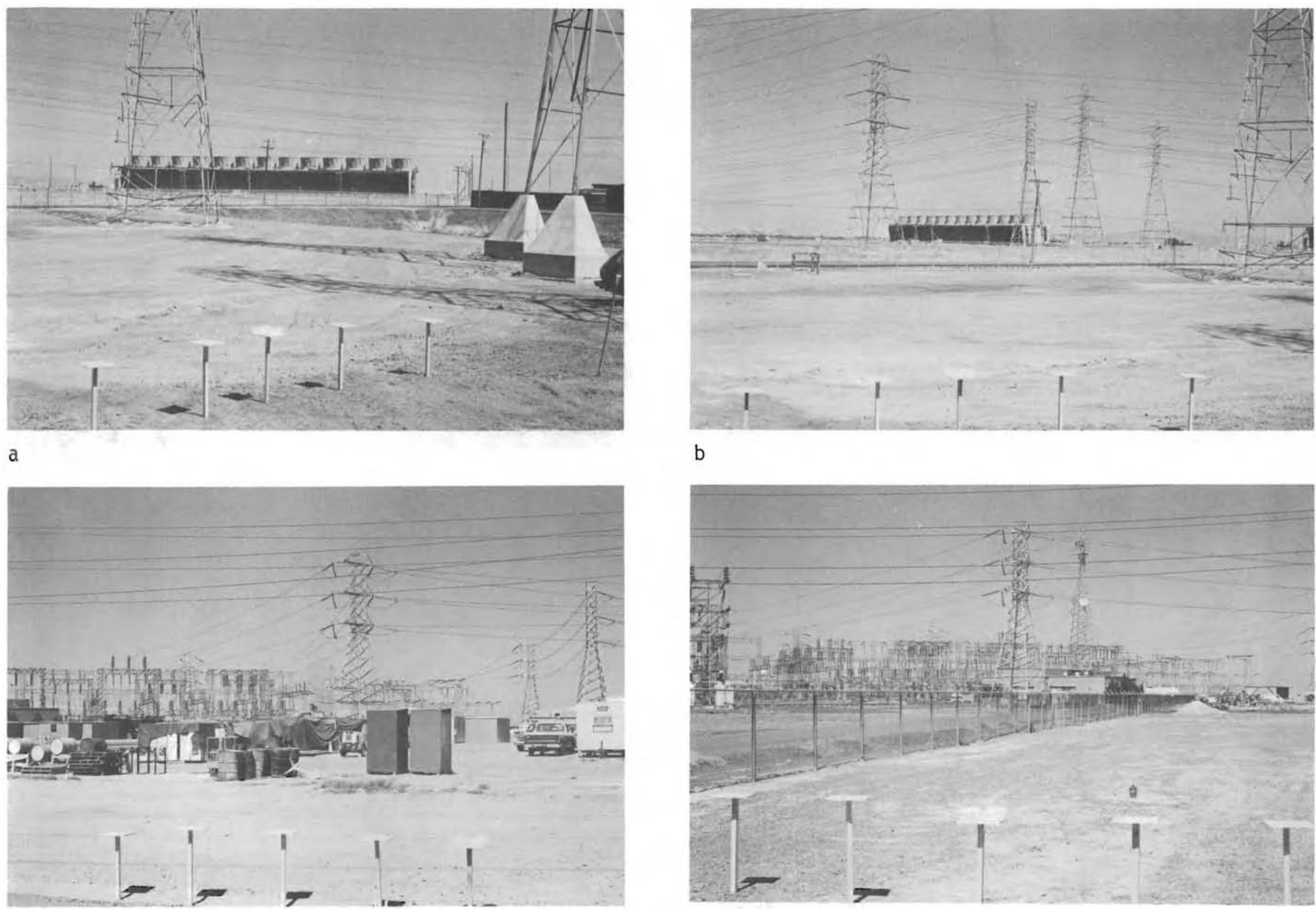

b

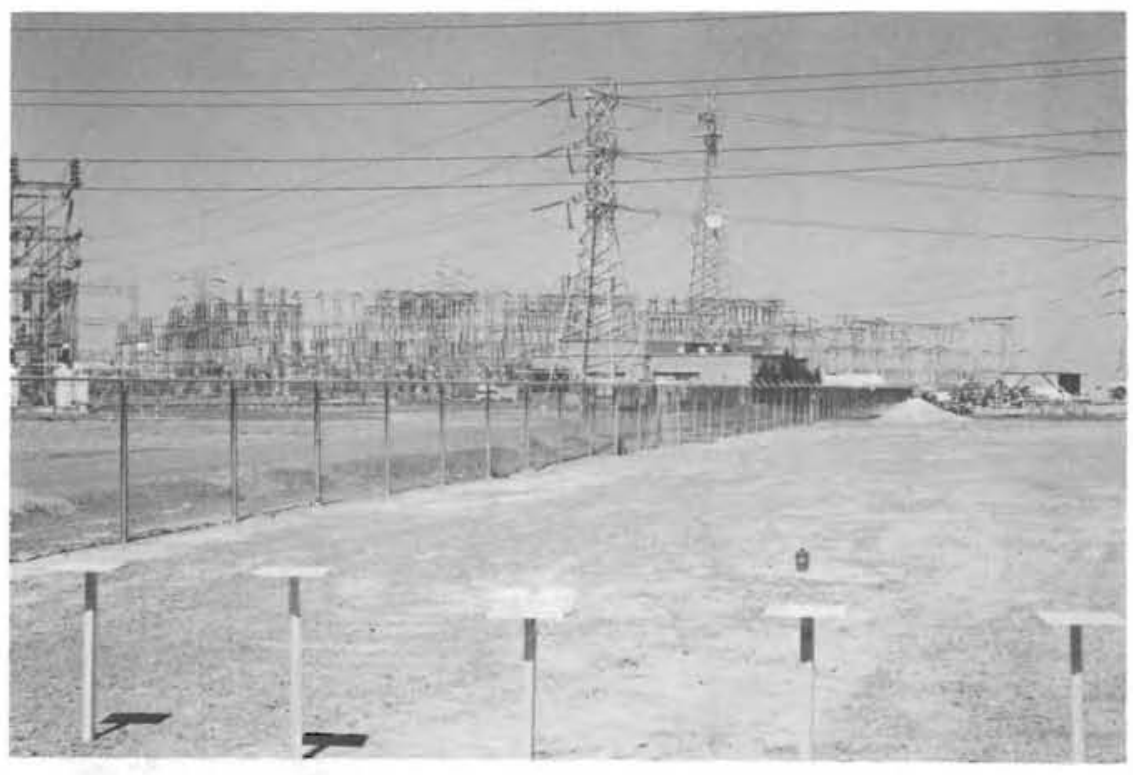

C

Figure B 16 


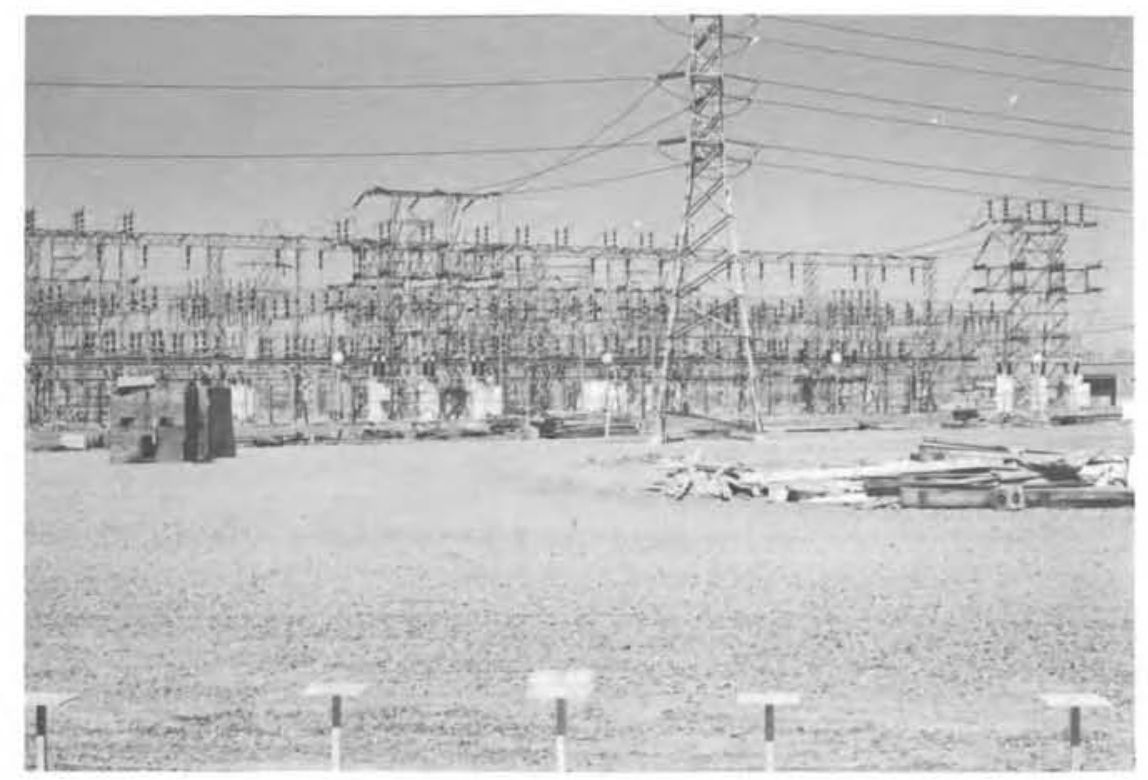

Co
1
0

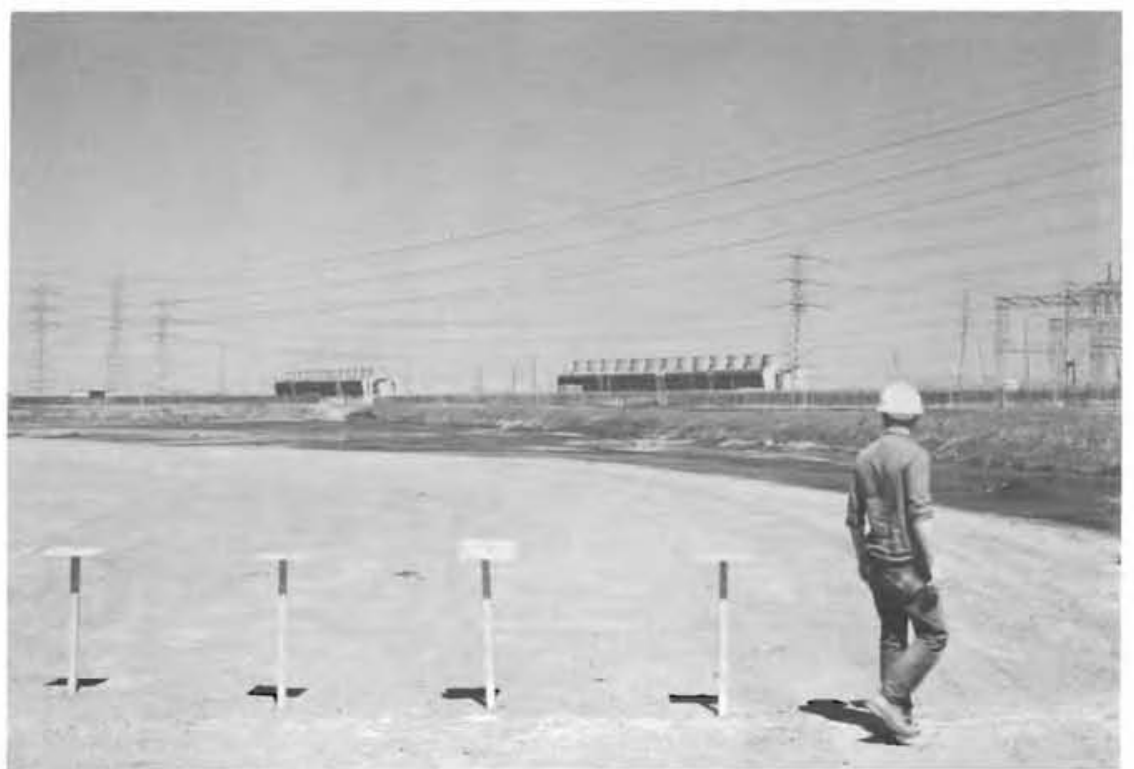

C

Figure B 17

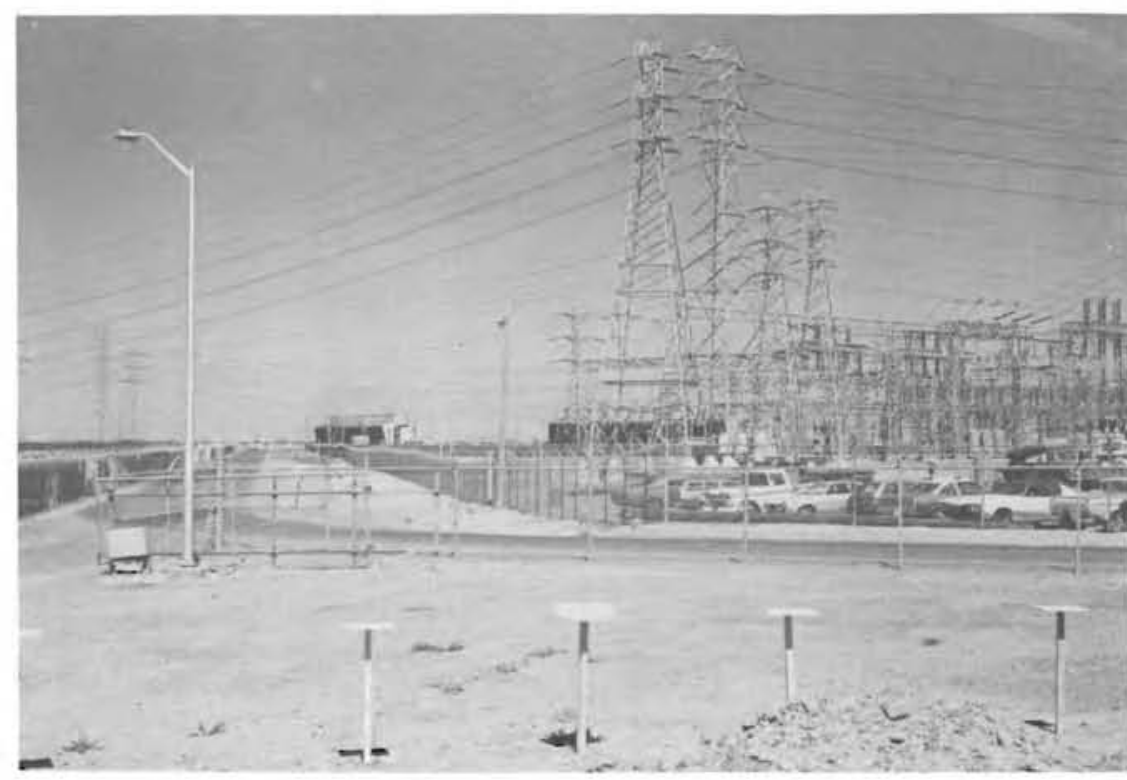

b

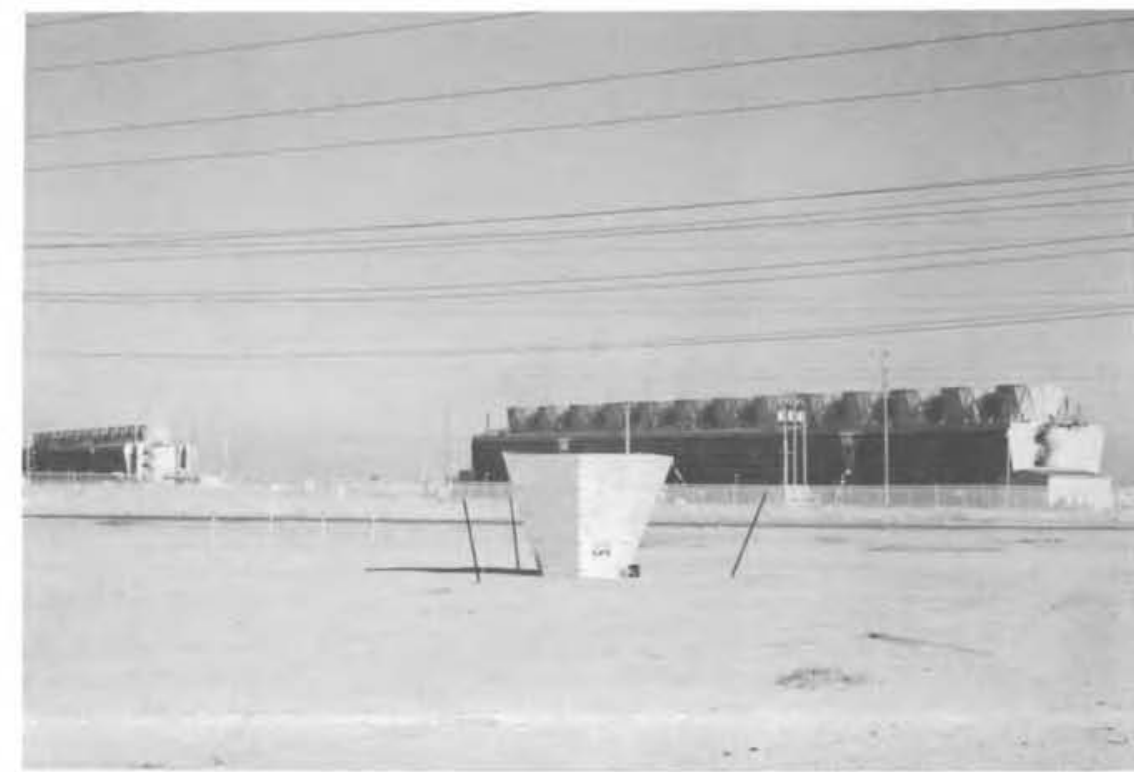


APPENDIX $C$

METEOROLOGICAL SUMMARIES 
TABLE C-1, Ten Minute Average, Meteorological Data for the Pittsburg Power Plant during the June 1978 Meter Drift Study

\begin{tabular}{|c|c|c|c|c|c|}
\hline Date & Time (PST) & Temp. $\left(C^{\circ}\right)$ & R.H. (\%) & Wind Speed ( $\left.\mathrm{ms}^{-1}\right)$ & Wind Direc. $\left(1^{\circ}\right)$ \\
\hline \multirow[t]{36}{*}{15 June } & 0700 & $M$ & $M$ & $M$ & M \\
\hline & 0710 & $M$ & $M$ & $M$ & M \\
\hline & 0720 & M & M & $M$ & M \\
\hline & 0730 & M & M & $M$ & $M$ \\
\hline & 0740 & M & M & $M$ & M \\
\hline & 0750 & 15.6 & 63.2 & 4.1 & 260.2 \\
\hline & 0800 & 16.2 & 61.4 & 4.5 & 257.1 \\
\hline & 0810 & 16.9 & 60.7 & 4.5 & 253.2 \\
\hline & 0820 & 17.2 & 57.1 & 4.7 & 262.1 \\
\hline & 0830 & 17.3 & 56.0 & 4.9 & 250.4 \\
\hline & 0840 & M & M & $M$ & M \\
\hline & 0850 & M & M & $M$ & M \\
\hline & 0900 & 19.1 & 52.2 & 4.7 & 260.3 \\
\hline & 0910 & 19.4 & 50.4 & 4.1 & 254.1 \\
\hline & 0920 & 19.6 & 49.7 & 5.2 & 250.1 \\
\hline & 0930 & 20.0 & 48.4 & 4.5 & 250.6 \\
\hline & 0940 & 20.1 & 47.2 & 4.7 & 260.3 \\
\hline & 0950 & 20.2 & 46.3 & 4.1 & 267.4 \\
\hline & 1000 & 20.5 & 46.0 & 5.2 & 271.3 \\
\hline & 1010 & 20.9 & 45.9 & 4.6 & 264.3 \\
\hline & 1020 & 21.2 & 45.7 & 4.5 & 268.2 \\
\hline & 1030 & 21.3 & 45.5 & 4.4 & 265.4 \\
\hline & 1040 & 21.4 & 46.0 & 4.6 & 270.4 \\
\hline & 1050 & 21.5 & 45.0 & 4.8 & 269.3 \\
\hline & 1100 & 21.5 & 45.8 & 4.1 & 281.2 \\
\hline & 110 & 21.7 & 46.1 & 5.0 & 290.4 \\
\hline & 1120 & 21.9 & 45.7 & 5.2 & 285.4 \\
\hline & 1130 & 22.0 & 45.0 & 4.9 & 276.1 \\
\hline & 1140 & 22.3 & 45.0 & 5.5 & 284.1 \\
\hline & 1150 & 22.4 & 45.2 & 6.1 & 292.1 \\
\hline & 1200 & 22.5 & 45.0 & 5.9 & 300.4 \\
\hline & 1210 & $M$ & $M$ & $M$ & $M$ \\
\hline & 1220 & $M$ & $M$ & $M$ & M \\
\hline & 1230 & $M$ & $M$ & M & M \\
\hline & 1240 & M & $M$ & $M$ & $M$ \\
\hline & 1250 & M & $M$ & $M$ & $M$ \\
\hline
\end{tabular}




\begin{tabular}{|c|c|c|c|c|c|}
\hline Date & Time (PST) & Temp. $\left(C^{\circ}\right)$ & R.H. (\%) & Wind Speed $\left(\mathrm{ms}^{-1}\right)$ & Wind Direc. $\left({ }^{\circ}\right)$ \\
\hline \multirow{36}{*}{16 June } & 0700 & 14.8 & 67.4 & 4.1 & 262.7 \\
\hline & 0710 & 15.2 & 69.3 & 4.3 & 268.5 \\
\hline & 0720 & 15.2 & 68.4 & 4.4 & 270.3 \\
\hline & 0730 & 15.4 & 67.2 & 5.0 & 280.1 \\
\hline & 0740 & 15.5 & 67.7 & 4.9 & 264.5 \\
\hline & 0750 & 15.7 & 65.1 & 4.5 & 260.5 \\
\hline & 0800 & 15.7 & 63.2 & 4.5 & 269.3 \\
\hline & 0810 & 16.3 & 60.8 & 4.0 & 266.7 \\
\hline & 0820 & 16.8 & 59.4 & 4.1 & 270.1 \\
\hline & 0830 & 17.0 & 59.0 & 4.2 & 265.3 \\
\hline & 0840 & 17.5 & 57.4 & 4.6 & 265.8 \\
\hline & 0850 & 17.7 & 56.3 & 4.3 & 270.4 \\
\hline & 0900 & 18.2 & 55.2 & 4.9 & 269.8 \\
\hline & 0910 & 18.8 & 54.1 & 4.8 & 264.3 \\
\hline & 0920 & 19.4 & 51.7 & 4.5 & 268.4 \\
\hline & 0930 & 19.9 & 50.3 & 4.3 & 269.3 \\
\hline & 0940 & 20.1 & 50.0 & 4.2 & 269.8 \\
\hline & 0950 & 20.6 & 49.8 & 4.5 & 268.4 \\
\hline & 1000 & 21.0 & 48.0 & 4.9 & 268.3 \\
\hline & 1010 & 21.5 & 46.1 & 4.8 & 268.0 \\
\hline & 1020 & 21.3 & 45.3 & 4.8 & 265.1 \\
\hline & 1030 & 21.8 & 44.0 & 4.7 & 264.0 \\
\hline & 1040 & 21.9 & 43.1 & 4.8 & 275.0 \\
\hline & 1050 & 22.3 & 41.7 & 5.0 & 280.0 \\
\hline & 1100 & 22.9 & 40.3 & 5.0 & 268.3 \\
\hline & 110 & 22.8 & 38.8 & 5.0 & 260.4 \\
\hline & 1120 & 23.5 & 38.0 & 5.1 & 265.3 \\
\hline & 1130 & 23.6 & 37.3 & 5.1 & 270.4 \\
\hline & 1140 & 23.6 & 37.4 & 5.2 & 270.3 \\
\hline & 1150 & 23.8 & 37.0 & 4.7 & 272.4 \\
\hline & 1200 & 24.4 & 36.5 & 5.0 & 280.5 \\
\hline & 1210 & 24.6 & 36.0 & 5.1 & 278.6 \\
\hline & 1220 & 24.4 & 35.2 & 5.1 & 290.4 \\
\hline & 1230 & 25.0 & 35.0 & 5.0 & 306.4 \\
\hline & 1240 & 25.2 & 34.3 & 5.0 & 289.3 \\
\hline & 1250 & 25.1 & 34.7 & 5.0 & 285.3 \\
\hline
\end{tabular}




\begin{tabular}{|c|c|c|c|c|c|}
\hline Date & Time(PST) & Temp. $\left(C^{\circ}\right)$ & R.H. (\%) & Wind Speed $\left(\mathrm{ms}^{-1}\right)$ & Wind Direc. $\left({ }^{\circ}\right)$ \\
\hline \multirow[t]{36}{*}{17 June } & 0700 & 17.2 & 59.4 & 2.5 & 159.2 \\
\hline & 0710 & 17.7 & 58.5 & 2.8 & 180.4 \\
\hline & 0720 & 17.9 & 58.6 & 2.4 & 160.3 \\
\hline & 0730 & 17.9 & 58.0 & 2.0 & 205.3 \\
\hline & 0740 & 18.3 & 57.4 & 3.1 & 181.4 \\
\hline & 0750 & 18.5 & 57.0 & 2.7 & 191.4 \\
\hline & 0800 & 18.4 & 56.7 & 2.9 & 196.7 \\
\hline & 0810 & 18.6 & 56.6 & 2.0 & 175.6 \\
\hline & 0820 & 18.9 & 56.0 & 1.8 & 185.3 \\
\hline & 0830 & 19.1 & 56.2 & 1.7 & 196.3 \\
\hline & 0840 & 19.0 & 57.1 & 1.9 & 210.5 \\
\hline & 0850 & 19.3 & 56.4 & 2.4 & 230.6 \\
\hline & 0900 & 19.4 & 56.0 & 2.0 & 237.4 \\
\hline & 0910 & 19.4 & 55.8 & 3.5 & 252.4 \\
\hline & 0920 & 20.0 & 56.3 & 3.3 & 294.7 \\
\hline & 0930 & 20.4 & 56.7 & 3.0 & 264.3 \\
\hline & 0940 & 20.5 & 56.1 & 3.0 & 265.7 \\
\hline & 0950 & 20.6 & 55.9 & 2.7 & 270.3 \\
\hline & 1000 & 20.5 & 55.6 & 3.6 & 294.4 \\
\hline & 1010 & 20.9 & 55.1 & 3.4 & 310.1 \\
\hline & 1020 & 21.5 & 55.3 & 4.6 & 305.4 \\
\hline & 1030 & 21.9 & 55.7 & 4.5 & 290.5 \\
\hline & 1040 & 22.3 & 55.6 & 4.0 & 295.6 \\
\hline & 1050 & 22.6 & 54.9 & 5.6 & 300.4 \\
\hline & 1100 & 22.6 & 54.7 & 5.5 & 300.7 \\
\hline & 1110 & 22.8 & 54.8 & 4.9 & 290.8 \\
\hline & 1120 & 23.0 & 54.9 & 5.2 & 295.6 \\
\hline & 1130 & 23.4 & 54.7 & 5.0 & 293.2 \\
\hline & 1140 & 23.7 & 52.4 & 5.4 & 290.1 \\
\hline & 1150 & 23.9 & 50.3 & 5.3 & 285.4 \\
\hline & 1200 & 24.0 & 49.6 & 4.9 & 292.5 \\
\hline & 1210 & 24.2 & 48.1 & 5.7 & 290.7 \\
\hline & 1220 & 24.8 & 47.0 & 5.2 & 298.4 \\
\hline & 1230 & 24.9 & 46.0 & 5.4 & 295.6 \\
\hline & 1240 & 25.4 & 43.1 & 5.5 & 292.0 \\
\hline & 1250 & 25.5 & 42.0 & 5.5 & 286.0 \\
\hline
\end{tabular}




\begin{tabular}{|c|c|c|c|c|c|}
\hline Date & Time (PST) & Temp. $\left(C^{\circ}\right)$ & R.H. (\%) & Wind Speed (ms $\left.{ }^{-1}\right)$ & Wind Direc. $\left({ }^{\circ}\right)$ \\
\hline \multirow[t]{36}{*}{18 June } & 0700 & 14.8 & 71.3 & 7.0 & 240.7 \\
\hline & 0710 & 14.9 & 70.4 & 7.2 & 238.3 \\
\hline & 0720 & 14.8 & 70.8 & 6.9 & 239.4 \\
\hline & 0730 & 15.0 & 70.0 & 7.3 & 230.3 \\
\hline & 0740 & 14.9 & 69.2 & 7.4 & 228.6 \\
\hline & 0750 & M & $M$ & M & M \\
\hline & 0800 & M & M & M & M \\
\hline & 0810 & M & M & M & M \\
\hline & 0820 & $M$ & M & $M$ & M \\
\hline & 0830 & $M$ & $M$ & M & M \\
\hline & 0840 & M & $M$ & M & M \\
\hline & 0850 & M & M & M & M \\
\hline & 0900 & M & $M$ & M & M \\
\hline & 0910 & M & $M$ & M & $M$ \\
\hline & 0920 & M & $M$ & M & $M$ \\
\hline & 0930 & M & $M$ & M & $M$ \\
\hline & 0940 & M & M & M & $M$ \\
\hline & 0950 & $M$ & $M$ & $M$ & M \\
\hline & 1000 & $M$ & $M$ & $M$ & M \\
\hline & 1010 & $M$ & $M$ & $M$ & $M$ \\
\hline & 1020 & M & $M$ & M & M \\
\hline & 1030 & 17.9 & 58.2 & 7.0 & 247.3 \\
\hline & 1040 & 18.5 & 56.4 & 6.9 & 250.4 \\
\hline & 1050 & 19.3 & 55.7 & 7.1 & 243.2 \\
\hline & 1100 & M & $M$ & M & M \\
\hline & 110 & $M$ & M & M & $M$ \\
\hline & 1120 & 20.3 & 54.0 & 7.1 & 245.0 \\
\hline & 1130 & 20.7 & 53.9 & 7.5 & 247.1 \\
\hline & 1140 & 20.5 & 53.0 & 8.0 & 245.6 \\
\hline & 1150 & 20.9 & 52.5 & 7.1 & 249.4 \\
\hline & 1200 & 21.0 & 52.4 & 8.0 & 250.6 \\
\hline & 1210 & 21.1 & 52.0 & 8.0 & 255.3 \\
\hline & 1220 & 21.7 & 51.6 & 7.5 & 256.7 \\
\hline & 1230 & 21.6 & 51.4 & 7.6 & 249.4 \\
\hline & 1240 & 21.8 & 50.7 & 7.7 & 255.7 \\
\hline & 1250 & 21.8 & 50.2 & 8.6 & 260.3 \\
\hline
\end{tabular}




\begin{tabular}{|c|c|c|c|c|c|}
\hline Date & time (PST) & Temp. $\left(C^{\circ}\right)$ & R.H. (q) & Wind Speed $\left(\mathrm{ms}^{-1}\right)$ & Wind Direc. $\left({ }^{\circ}\right)$ \\
\hline \multirow[t]{36}{*}{19 June } & 0700 & 14.8 & 85.6 & 4.6 & 280.5 \\
\hline & 0710 & 14.7 & 83.4 & 4.5 & 259.7 \\
\hline & 0720 & 15.3 & 81.7 & 4.4 & 267.4 \\
\hline & 0730 & 15.9 & 80.3 & 4.3 & 260.3 \\
\hline & 0740 & 16.1 & 78.4 & 4.1 & 274.3 \\
\hline & 0750 & 16.4 & 76.3 & 4.5 & 267.3 \\
\hline & 0800 & 16.8 & 75.2 & 4.3 & 253.4 \\
\hline & 0810 & 17.4 & 70.4 & 4.2 & 255.8 \\
\hline & 0820 & 17.5 & 69.8 & 4.3 & 259.4 \\
\hline & 0830 & 17.6 & 65.4 & 4.2 & 260.3 \\
\hline & 0840 & 17.9 & 67.8 & 4.6 & 265.4 \\
\hline & 0850 & 18.2 & 63.2 & 5.4 & 249.4 \\
\hline & 0900 & 18.1 & 61.0 & 5.5 & 247.8 \\
\hline & 0910 & 18.7 & 59.2 & 5.0 & 253.7 \\
\hline & 0920 & 19.2 & 58.4 & 4.5 & 254.8 \\
\hline & 0930 & 19.7 & 57.3 & 4.6 & 255.7 \\
\hline & 0940 & 19.9 & 53.2 & 4.7 & 253.6 \\
\hline & 0950 & 20.1 & 54.1 & 5.0 & 267.8 \\
\hline & 1000 & 20.6 & 53.8 & 4.8 & 272.9 \\
\hline & 1010 & 21.4 & 53.6 & 4.5 & 253.3 \\
\hline & 1020 & 21.5 & 52.4 & 5.0 & 265.5 \\
\hline & 1030 & 21.8 & 53.0 & 5.3 & 257.8 \\
\hline & 1040 & 22.3 & 52.7 & 6.4 & 264.7 \\
\hline & 1050 & 22.8 & 53.4 & 5.5 & 272.3 \\
\hline & 1100 & 22.9 & 55.6 & 6.0 & 285.3 \\
\hline & 110 & 23.4 & 53.4 & 5.3 & 290.4 \\
\hline & 1120 & 23.8 & 52.6 & 4.9 & 304.3 \\
\hline & 1130 & 24.0 & 53.0 & 5.2 & 312.4 \\
\hline & 1140 & 24.1 & 54.7 & 6.0 & 285.6 \\
\hline & 1150 & 23.9 & 52.1 & 6.5 & 290.4 \\
\hline & 1200 & 24.2 & 50.7 & 6.3 & 286.3 \\
\hline & 1210 & 24.5 & 52.8 & 7.4 & 287.4 \\
\hline & 1220 & 24.7 & 52.7 & 7.0 & 290.4 \\
\hline & 1230 & 25.0 & 52.6 & 6.3 & 304.4 \\
\hline & 1240 & 25.3 & 53.4 & 6.9 & 306.8 \\
\hline & 1250 & 25.0 & 54.1 & 6.8 & 310.4 \\
\hline
\end{tabular}




\begin{tabular}{|c|c|c|c|c|c|}
\hline Date & Time (PST) & Temp. $\left(C^{0}\right)$ & R.H.(\%) & Wind Speed $\left(\mathrm{ms}^{-1}\right)$ & Wind Direc. $\left({ }^{\circ}\right)$ \\
\hline \multirow[t]{36}{*}{20 June } & 0700 & M & M & M & $M$ \\
\hline & 0710 & M & M & M & M \\
\hline & $0720^{\circ}$ & M & M & M & M \\
\hline & 0730 & M & M & $M$ & $M$ \\
\hline & 0740 & M & M & M & M \\
\hline & 0750 & M & M & M & $M$ \\
\hline & 0800 & M & M & M & $M$ \\
\hline & 0810 & M & M & M & M \\
\hline & 0820 & M & M & M & M \\
\hline & 0830 & M & M & M & M \\
\hline & 0840 & M & M & M & M \\
\hline & 0850 & M & M & M & M \\
\hline & 0900 & M & M & M & M \\
\hline & 0910 & M & M & M & M \\
\hline & 0920 & 12.7 & 68.4 & 7.7 & 240.7 \\
\hline & 0930 & 13.1 & 67.9 & 7.9 & 242.6 \\
\hline & 0940 & 12.6 & 67.0 & 8.3 & 239.6 \\
\hline & 0950 & 12.8 & 65.3 & 8.0 & 242.4 \\
\hline & 1000 & 13.0 & 66.4 & 7.5 & 250.6 \\
\hline & 1010 & 13.3 & 64.2 & 8.5 & 249.6 \\
\hline & 1020 & 13.5 & 62.4 & 8.7 & 243.4 \\
\hline & 1030 & 13.7 & 60.3 & 7.9 & 248.7 \\
\hline & 1040 & 14.2 & 59.8 & 8.0 & 242.6 \\
\hline & 1050 & 14.1 & 57.4 & 7.7 & 247.4 \\
\hline & 1100 & 14.6 & 55.3 & 7.9 & 255.3 \\
\hline & 1110 & 15.3 & 54.2 & 8.0 & 256.4 \\
\hline & 1120 & 15.4 & 54.9 & 6.8 & 244.3 \\
\hline & 1130 & 15.0 & 55.7 & 7.3 & 248.8 \\
\hline & 1140 & 15.1 & 53.4 & 7.2 & 243.6 \\
\hline & 1150 & 15.9 & 52.4 & 7.7 & 243.7 \\
\hline & 1200 & 16.2 & 50.6 & 7.7 & 244.8 \\
\hline & 1210 & 16.3 & 49.8 & 8.4 & 243.4 \\
\hline & 1220 & 16.7 & 48.7 & 6.3 & 249.6 \\
\hline & 1230 & 17.4 & 47.3 & 6.9 & 240.6 \\
\hline & 1240 & 17.7 & 45.3 & 7.0 & 239.8 \\
\hline & 1250 & 18.0 & 42.4 & 6.9 & 237.6 \\
\hline
\end{tabular}




\begin{tabular}{|c|c|c|c|c|c|}
\hline Date & Time (PST) & Temp. $\left(C^{\circ}\right)$ & R.H. (\%) & Wind Speed (ms-1) & Wind Direc. $\left({ }^{\circ}\right)$ \\
\hline \multirow[t]{36}{*}{21 June } & 0700 & 14.7 & 80.6 & 4.1 & 265.3 \\
\hline & 0710 & 14.8 & 79.4 & 4.3 & 264.4 \\
\hline & 0720 & 14.6 & 78.3 & 4.5 & 280.7 \\
\hline & 0730 & 15.0 & 78.0 & 5.0 & 265.7 \\
\hline & 0740 & 15.8 & 77.6 & 4.6 & 249.3 \\
\hline & 0750 & 16.3 & 74.2 & 4.8 & 250.4 \\
\hline & 0800 & 16.4 & 70.3 & 4.9 & 257.3 \\
\hline & 0810 & 16.5 & 69.8 & 5.2 & 253.2 \\
\hline & 0820 & 16.8 & 68.4 & 4.0 & 256.4 \\
\hline & 0830 & 17.0 & 68.7 & 4.0 & 240.7 \\
\hline & 0840 & 17.2 & 68.0 & 5.2 & 245.6 \\
\hline & 0850 & 17.9 & 67.7 & 6.4 & 252.3 \\
\hline & 0900 & 18.0 & 67.6 & 7.8 & 245.8 \\
\hline & 0910 & 18.2 & 67.1 & 8.2 & 246.3 \\
\hline & 0920 & 18.1 & 66.2 & 7.0 & 242.4 \\
\hline & 0930 & 18.4 & 66.0 & 6.5 & 248.7 \\
\hline & 0940 & 18.7 & 65.4 & 6.3 & 245.6 \\
\hline & 0950 & 19.0 & 65.0 & 6.0 & 245.8 \\
\hline & 1000 & 19.3 & 63.2 & 7.4 & 250.6 \\
\hline & 1010 & 19.4 & 63.0 & 6.5 & 259.7 \\
\hline & 1020 & 19.8 & 61.4 & 6.3 & 233.8 \\
\hline & 1030 & 19.7 & 60.0 & 6.2 & 239.8 \\
\hline & 1040 & 20.0 & 59.3 & 5.5 & 247.8 \\
\hline & 1050 & 20.6 & 58.7 & 5.5 & 249.4 \\
\hline & 1100 & 21.0 & 57.4 & 5.0 & 245.3 \\
\hline & 1וו1 & 21.1 & 56.4 & 7.0 & 246.3 \\
\hline & 1120 & 21.0 & 56.8 & 7.1 & 243.3 \\
\hline & 1130 & 21.6 & 54.2 & 7.3 & 245.8 \\
\hline & 1140 & 21.5 & 53.4 & 6.4 & 246.3 \\
\hline & 1150 & 22.7 & 50.7 & 5.5 & 248.4 \\
\hline & 1200 & 23.0 & 50.6 & 5.4 & 249.3 \\
\hline & 1210 & 23.2 & 50.4 & 5.0 & 260.4 \\
\hline & 1220 & 23.5 & 49.8 & 5.7 & 269.7 \\
\hline & 1230 & 24.4 & 47.3 & 5.3 & 275.3 \\
\hline & 1240 & 24.8 & 46.4 & 5.2 & 280.4 \\
\hline & 1250 & 24.9 & 45.2 & 5.1 & 275.3 \\
\hline
\end{tabular}




\begin{tabular}{|c|c|c|c|c|c|}
\hline Date & Time (PST) & Temp. $\left(C^{\circ}\right)$ & R.H. (\%) & Wind Speed $\left(\mathrm{ms}^{-1}\right)$ & Wind Direc. $\left({ }^{\circ}\right)$ \\
\hline \multirow[t]{36}{*}{22 June } & 0700 & 14.3 & 79.4 & 6.7 & 190.7 \\
\hline & 0710 & 14.8 & 75.3 & 6.3 & 210.3 \\
\hline & 0720 & 15.0 & 76.4 & 6.0 & 220.4 \\
\hline & 0730 & 15.2 & 76.0 & 5.2 & 218.7 \\
\hline & 0740 & 15.0 & 75.0 & 5.8 & 225.6 \\
\hline & 0750 & 15.6 & 73.1 & 5.0 & 230.4 \\
\hline & 0800 & 15.7 & 70.4 & 5.6 & 228.6 \\
\hline & 0810 & 15.9 & 69.3 & 5.5 & 219.6 \\
\hline & 0820 & 16.2 & 68.1 & 6.3 & 230.4 \\
\hline & 0830 & 16.3 & 67.4 & 6.2 & 226.3 \\
\hline & 0840 & 16.3 & 67.3 & 7.0 & 230.4 \\
\hline & 0850 & 16.5 & 66.4 & 6.1 & 239.8 \\
\hline & 0900 & 16.8 & 65.3 & 5.4 & 245.6 \\
\hline & 0910 & 17.0 & 63.2 & 5.3 & 256.3 \\
\hline & 0920 & 17.3 & 61.4 & 5.2 & 255.2 \\
\hline & 0930 & 17.4 & 59.7 & 6.8 & 250.4 \\
\hline & 0940 & 17.8 & 52.7 & 7.3 & 250.3 \\
\hline & 0950 & 18.0 & 56.4 & 7.0 & 256.4 \\
\hline & 1000 & 18.2 & 53.2 & 6.3 & 258.7 \\
\hline & 1010 & 18.6 & 50.4 & 7.5 & 260.3 \\
\hline & 1020 & 18.9 & 50.6 & 6.0 & 243.2 \\
\hline & 1030 & 19.3 & 49.8 & 6.8 & 240.4 \\
\hline & 1040 & 19.8 & 47.3 & 6.3 & 247.8 \\
\hline & 1050 & 19.8 & 47.4 & 6.2 & 246.3 \\
\hline & 1100 & 20.0 & 46.3 & 6.0 & 245.1 \\
\hline & סווו & 20.3 & 45.3 & 5.0 & 249.2 \\
\hline & 1120 & 20.9 & 45.0 & 5.1 & 247.3 \\
\hline & 1130 & 21.4 & 44.5 & 6.0 & 250.4 \\
\hline & 1140 & 21.8 & 43.8 & 6.2 & 252.3 \\
\hline & 1150 & 22.3 & 41.4 & 6.3 & 269.3 \\
\hline & 1200 & 22.9 & 42.0 & 6.3 & 260.4 \\
\hline & 1210 & 23.1 & 41.6 & 6.3 & 255.7 \\
\hline & 1220 & 23.2 & 41.0 & 5.0 & 256.8 \\
\hline & 1230 & 23.4 & 39.8 & 5.2 & 253.4 \\
\hline & 1240 & 24.0 & 39.6 & 5.1 & 252.4 \\
\hline & 1250 & 23.9 & 38.0 & 5.1 & 256.6 \\
\hline
\end{tabular}




\begin{tabular}{|c|c|c|c|c|c|}
\hline Date & Time (PST) & Temp. $\left(C^{0}\right)$ & R.H. (q) & Wind Speed $\left(\mathrm{ms}^{-1}\right)$ & Wind Direc. $\left({ }^{\circ}\right)$ \\
\hline \multirow[t]{36}{*}{23 June } & 0700 & 14.0 & 83.6 & 6.0 & 248.6 \\
\hline & 0710 & 14.6 & 82.1 & 6.3 & 250.3 \\
\hline & 0720 & 14.5 & 80.7 & 6.5 & 249.3 \\
\hline & 0730 & 15.0 & 81.0 & 7.4 & 260.4 \\
\hline & 0740 & 15.0 & 80.6 & 8.3 & 243.4 \\
\hline & 0750 & 14.9 & 80.5 & 8.4 & 245.8 \\
\hline & 0800 & 15.6 & 79.3 & 8.7 & 250.6 \\
\hline & 0810 & 15.8 & 79.8 & 9.3 & 247.4 \\
\hline & 0820 & 16.0 & 79.4 & 9.8 & 247.6 \\
\hline & 0830 & 16.1 & 78.3 & 10.6 & 240.3 \\
\hline & 0840 & $M$ & $M$ & M & $M$ \\
\hline & 0850 & $M$ & $M$ & M & $M$ \\
\hline & 9000 & M & M & $M$ & M \\
\hline & 9100 & $M$ & $M$ & $M$ & M \\
\hline & 0920 & M & $M$ & $M$ & M \\
\hline & 0930 & M & $M$ & M & $M$ \\
\hline & 0940 & $M$ & M & $M$ & $M$ \\
\hline & 0950 & $M$ & M & $M$ & M \\
\hline & 1000 & 17.3 & 70.0 & 12.0 & 243.6 \\
\hline & 1010 & 17.9 & 69.3 & 11.6 & 245.8 \\
\hline & 1020 & 18.3 & 68.4 & 10.5 & 250.6 \\
\hline & 1030 & 18.6 & 68.0 & 9.4 & 245.7 \\
\hline & 1040 & 18.6 & 67.3 & 12.7 & 245.8 \\
\hline & 1050 & 18.8 & 67.5 & 10.3 & 250.6 \\
\hline & 1100 & 19.3 & 67.0 & 9.6 & 240.0 \\
\hline & 1110 & 19.4 & 66.5 & 8.5 & 239.8 \\
\hline & 1120 & $M$ & M & M & M \\
\hline & 1130 & $M$ & $M$ & M & $M$ \\
\hline & 1140 & $M$ & $M$ & $M$ & $M$ \\
\hline & 1150 & $M$ & $M$ & $M$ & $M$ \\
\hline & 1200 & $M$ & $M$ & $M$ & $M$ \\
\hline & 1210 & $M$ & $M$ & $M$ & $M$ \\
\hline & 1220 & 20.7 & 56.4 & 6.8 & 237.0 \\
\hline & 1230 & 21.3 & 55.0 & 6.9 & 225.6 \\
\hline & 1240 & 22.4 & 53.2 & 7.3 & 230.6 \\
\hline & 1250 & 23.4 & 50.6 & 7.2 & 233.4 \\
\hline
\end{tabular}




\begin{tabular}{|c|c|c|c|c|c|}
\hline Date & Time (PST) & Temp. $\left(C^{\circ}\right)$ & R.H. (\%) & Wind Speed $\left(\mathrm{ms}^{-1}\right)$ & Wind Direc. $\left({ }^{\circ}\right)$ \\
\hline \multirow[t]{36}{*}{24 June } & 0700 & 13.0 & 79.3 & 10.6 & 235.9 \\
\hline & 0710 & 13.3 & 79.0 & 10.8 & 240.6 \\
\hline & 0720 & 13.8 & 78.4 & 9.7 & 249.8 \\
\hline & 0730 & 14.0 & 78.0 & 9.9 & 250.6 \\
\hline & 0740 & 14.1 & 75.6 & 9.0 & 245.7 \\
\hline & 0750 & 14.1 & 74.2 & 8.5 & 247.3 \\
\hline & 0800 & 14.3 & 73.1 & 7.4 & 247.8 \\
\hline & 0810 & 14.6 & 71.6 & 7.3 & 249.4 \\
\hline & 0820 & 14.8 & 70.0 & 7.0 & 250.6 \\
\hline & 0830 & 15.0 & 68.4 & 6.1 & 252.3 \\
\hline & 0840 & 15.2 & 68.0 & 6.7 & 248.4 \\
\hline & 0850 & 15.8 & 66.9 & 7.2 & 240.6 \\
\hline & 0900 & 16.2 & 66.1 & 8.4 & 235.4 \\
\hline & 0910 & 16.6 & 64.2 & 8.8 & 230.0 \\
\hline & 0920 & 16.8 & 62.1 & 8.0 & 228.0 \\
\hline & 0930 & 17.4 & 60.4 & 8.3 & 242.3 \\
\hline & 0940 & 17.8 & 58.6 & 8.8 & 248.6 \\
\hline & 0950 & 18.0 & 55.4 & 8.9 & 257.4 \\
\hline & 1000 & 18.6 & 53.1 & 9.6 & 260.3 \\
\hline & 1010 & 18.8 & 50.4 & 9.7 & 270.4 \\
\hline & 1020 & 19.3 & 49.7 & 9.7 & 268.3 \\
\hline & 1030 & 19.6 & 48.4 & 8.6 & 243.4 \\
\hline & 1040 & 20.0 & 48.0 & 8.5 & 250.6 \\
\hline & 1050 & 20.4 & 47.6 & 8.0 & 255.6 \\
\hline & 1100 & 20.5 & 47.0 & 7.7 & 260.3 \\
\hline & סווו & 20.6 & 46.5 & 7.7 & 254.3 \\
\hline & 1120 & 20.8 & 46.0 & 7.8 & 253.2 \\
\hline & 1130 & 21.0 & 45.7 & 7.8 & 240.6 \\
\hline & 1140 & 21.2 & 44.8 & 7.7 & 258.7 \\
\hline & 1150 & 21.8 & 44.8 & 8.0 & 248.3 \\
\hline & 1200 & 22.3 & 43.6 & 7.2 & 254.3 \\
\hline & 1210 & 22.8 & 42.7 & 7.3 & 240.6 \\
\hline & 1220 & 23.0 & 42.0 & 7.0 & 241.6 \\
\hline & 1230 & 23.4 & 41.9 & 6.4 & 250.4 \\
\hline & 1240 & 23.8 & 40.6 & 7.0 & 250.2 \\
\hline & 1250 & 24.0 & 40.0 & 7.0 & 255.2 \\
\hline
\end{tabular}


TABLE C-2.
Tertical Profiles Derived from
Tethered-Balloon System

\begin{tabular}{|c|c|c|c|c|c|c|c|}
\hline Date & Time(PST) & Height $(m)$ & $\operatorname{Temp}\left(C^{\circ}\right)$ & R.H. (\%) & $\begin{array}{l}\text { Wind } \\
\text { Speed }\left(\mathrm{ms}^{-1}\right)\end{array}$ & $\begin{array}{l}\text { Wind } \\
\text { Direct. }\left({ }^{\circ}\right)\end{array}$ & Comment \\
\hline \multirow[t]{13}{*}{16 June } & \multirow{4}{*}{$\begin{array}{l}0858- \\
0901\end{array}$} & 2 & 19.6 & 49.0 & 3.0 & 271 & \multirow{4}{*}{$\begin{array}{l}\text { one } \\
\text { profile }\end{array}$} \\
\hline & & 7 & 19.9 & 50.8 & 5.6 & 278 & \\
\hline & & 25 & 18.6 & 51.4 & 5.5 & 241 & \\
\hline & & 41 & 18.5 & 53.7 & 6.2 & 267 & \\
\hline & \multirow{4}{*}{$\begin{array}{l}0943- \\
0948\end{array}$} & 12 & 20.9 & 40.4 & 6.6 & 224 & \multirow{4}{*}{$\begin{array}{l}\text { two } \\
\text { profiles }\end{array}$} \\
\hline & & 22 & 20.6 & 50.4 & 6.2 & 244 & \\
\hline & & 35 & 20.7 & 58.2 & 5.9 & 270 & \\
\hline & & 52 & 20.6 & 57.0 & 5.9 & 269 & \\
\hline & \multirow{5}{*}{$\begin{array}{l}1034- \\
1037\end{array}$} & 6 & 23.0 & 41.4 & 2.5 & 223 & \multirow{5}{*}{$\begin{array}{l}\text { one } \\
\text { profile }\end{array}$} \\
\hline & & 39 & 23.4 & 44.9 & 4.2 & 293 & \\
\hline & & 60 & 21.2 & 50.1 & 6.2 & 302 & \\
\hline & & 78 & 22.6 & 64.1 & 7.6 & 49 & \\
\hline & & 108 & 22.1 & 59.9 & 4.7 & 271 & \\
\hline \multirow[t]{16}{*}{17 June } & \multirow{6}{*}{$\begin{array}{l}0730- \\
0744\end{array}$} & 9 & 18.0 & 65.2 & 2.4 & 276 & \multirow{6}{*}{$\begin{array}{l}\text { two } \\
\text { profiles }\end{array}$} \\
\hline & & 18 & 17.8 & 65.7 & 2.3 & 299 & \\
\hline & & 33 & 17.9 & 65.4 & 2.0 & 322 & \\
\hline & & 58 & 17.6 & 67.3 & 2.2 & 338 & \\
\hline & & 81 & 17.5 & 64.6 & 1.7 & 340 & \\
\hline & & 100 & 17.6 & 60.7 & 1.3 & 17 & \\
\hline & \multirow{6}{*}{$\begin{array}{l}0829- \\
0848\end{array}$} & 2.0 & 20.0 & 51.8 & 2.4 & 297 & \multirow{6}{*}{$\begin{array}{l}\text { two } \\
\text { profiles }\end{array}$} \\
\hline & & 35 & 19.5 & 50.9 & 2.8 & 289 & \\
\hline & & 45 & 19.3 & 45.8 & 2.6 & 303 & \\
\hline & & 72 & 19.4 & 43.6 & 1.6 & 301 & \\
\hline & & 95 & 19.1 & 43.9 & 1.1 & 278 & \\
\hline & & 115 & 19.0 & 43.7 & 1.0 & 280 & \\
\hline & \multirow{4}{*}{$\begin{array}{l}0940- \\
0943\end{array}$} & 16 & 21.0 & 56.1 & 5.1 & 323 & \multirow{4}{*}{$\begin{array}{l}\text { one } \\
\text { profile }\end{array}$} \\
\hline & & 39 & 21.4 & 53.7 & 4.9 & 294 & \\
\hline & & 61 & 21.8 & 38.8 & 4.4 & 284 & \\
\hline & & 106 & 22.1 & 34.4 & 3.5 & 272 & \\
\hline
\end{tabular}




\begin{tabular}{|c|c|c|c|c|c|c|c|}
\hline Date & Time (PST) & Height (m) & $\operatorname{Temp}\left(C^{\circ}\right)$ & R.H. (\%) & $\begin{array}{l}\text { Wind } \\
\text { Speed (ms -1) }\end{array}$ & $\begin{array}{l}\text { Wind } \\
\text { Direct. }\left({ }^{\circ}\right)\end{array}$ & Comment \\
\hline \multirow[t]{11}{*}{17 June } & \multirow{5}{*}{$\begin{array}{l}1047- \\
1058\end{array}$} & 20 & 21.6 & 59.9 & 6.3 & 316 & \multirow{5}{*}{$\begin{array}{l}\text { two } \\
\text { profiles }\end{array}$} \\
\hline & & 38 & 21.9 & 53.9 & 6.5 & 302 & \\
\hline & & 57 & 23.0 & 34.6 & 5.4 & 298 & \\
\hline & & 79 & 23.7 & 33.6 & 5.5 & 296 & \\
\hline & & 95 & 23.1 & 32.5 & 5.1 & 295 & \\
\hline & \multirow{6}{*}{$\begin{array}{l}1129- \\
1140\end{array}$} & 3 & 23.0 & 50.2 & 3.7 & 298 & \multirow{6}{*}{$\begin{array}{l}\text { two } \\
\text { profiles }\end{array}$} \\
\hline & & 22 & $22: 3$ & 50.6 & 6.2 & 335 & \\
\hline & & 47 & 22.7 & 38.6 & 7.2 & 304 & \\
\hline & & 72 & 22.8 & 35.4 & 6.5 & 302 & \\
\hline & & 95 & 22.9 & 37.4 & 5.2 & 301 & \\
\hline & & 113 & 22.9 & 37.6 & 5.5 & 299 & \\
\hline \multirow[t]{21}{*}{21 June } & \multirow{10}{*}{$\begin{array}{l}0717- \\
0729\end{array}$} & 4 & 14.7 & 77.7 & 6.3 & 253 & \multirow{10}{*}{$\begin{array}{l}\text { two } \\
\text { profiles } \\
\text { combined }\end{array}$} \\
\hline & & 22 & 14.7 & 76.4 & 5.7 & 267 & \\
\hline & & 30 & 14.5 & 76.6 & 6.1 & 248 & \\
\hline & & 43 & 14.3 & 77.7 & 5.9 & 256 & \\
\hline & & 52 & 14.2 & 78.2 & 6.1 & 255 & \\
\hline & & 76 & 14.0 & 78.7 & 6.0 & 254 & \\
\hline & & 83 & 13.8 & 79.3 & 6.1 & 250 & \\
\hline & & 91 & 13.8 & 80.1 & 6.4 & 244 & \\
\hline & & 104 & 13.6 & 80.2 & 6.6 & 246 & \\
\hline & & 112 & 13.5 & 80.7 & 6.3 & 253 & \\
\hline & \multirow{6}{*}{$\begin{array}{l}0850- \\
0859\end{array}$} & 6 & 15.3 & 75.5 & 8.2 & 227 & \multirow{6}{*}{$\begin{array}{l}\text { two } \\
\text { profiles } \\
\text { combined }\end{array}$} \\
\hline & & 31 & 15.6 & 70.8 & 9.6 & 225 & \\
\hline & & 55 & 15.5 & 71.1 & 8.5 & 242 & \\
\hline & & 73 & 15.3 & 71.6 & 9.5 & 224 & \\
\hline & & 90 & 15.2 & 72.2 & 9.1 & 233 & \\
\hline & & 115 & 14.8 & 71.8 & 9.2 & 228 & \\
\hline & \multirow{5}{*}{$\begin{array}{l}0932- \\
0942\end{array}$} & 4 & 18.5 & 64.2 & 6.4 & 232 & \multirow{5}{*}{$\begin{array}{l}\text { two } \\
\text { profiles } \\
\text { combined }\end{array}$} \\
\hline & & 35 & 17.0 & 66.9 & 7.7 & 238 & \\
\hline & & 56 & 16.6 & 66.8 & 7.2 & 242 & \\
\hline & & 73 & 16.4 & 67.7 & 7.2 & 250 & \\
\hline & & 98 & 16.2 & 68.0 & 7.6 & 233 & \\
\hline
\end{tabular}




\begin{tabular}{|c|c|c|c|c|c|c|c|}
\hline Date & Time (PST) & Height $(m)$ & $\operatorname{Temp}\left(C^{0}\right)$ & R.H. (\%) & $\begin{array}{l}\text { Wind } \\
\text { Speed }\left(\mathrm{ms}^{-1}\right)\end{array}$ & $\begin{array}{l}\text { Wind } \\
\text { Direct. }(\%) \\
\end{array}$ & Comment \\
\hline \multirow[t]{17}{*}{21 June } & \multirow{5}{*}{$\begin{array}{l}1015- \\
1023\end{array}$} & 7 & 18.6 & 61.9 & 5.3 & 226 & \multirow{5}{*}{$\begin{array}{l}\text { two } \\
\text { profiles } \\
\text { combined }\end{array}$} \\
\hline & & 20 & 18.4 & 62.4 & 7.5 & 233 & \\
\hline & & 49 & 17.7 & 64.5 & 7.8 & 241 & \\
\hline & & 74 & 17.6 & 64.8 & 6.8 & 244 & \\
\hline & & 96 & 17.2 & 65.9 & 7.2 & 240 & \\
\hline & \multirow{6}{*}{$\begin{array}{l}1047- \\
1055\end{array}$} & 5 & 19.9 & 56.5 & 5.6 & 229 & \multirow{6}{*}{$\begin{array}{l}\text { two } \\
\text { profiles }\end{array}$} \\
\hline & & 30 & 19.3 & 59.6 & 6.7 & 246 & \\
\hline & & 54 & 18.4 & 60.7 & 7.5 & 232 & \\
\hline & & 65 & 18.4 & 60.2 & 7.3 & 217 & \\
\hline & & 86 & 18.0 & 61.3 & 7.2 & 228 & \\
\hline & & 112 & 17.8 & 62.3 & 6.4 & 233 & \\
\hline & \multirow{6}{*}{$\begin{array}{l}1149- \\
1202\end{array}$} & 17 & 20.7 & 52.8 & 7.3 & 240 & \multirow{6}{*}{$\begin{array}{l}\text { two } \\
\text { profiles }\end{array}$} \\
\hline & & 34 & 20.1 & 54.3 & 7.1 & 233 & \\
\hline & & 43 & 19.9 & 55.0 & 7.1 & 249 & \\
\hline & & 63 & 19.8 & 54.5 & 6.5 & 254 & \\
\hline & & 78 & 19.9 & 54.2 & 6.9 & 238 & \\
\hline & & 94 & 19.5 & 55.8 & 5.8 & 256 & \\
\hline \multirow[t]{13}{*}{23 June } & \multirow{8}{*}{$\begin{array}{l}1418- \\
1424\end{array}$} & 5 & 26.8 & 36.4 & 5.9 & 238 & \multirow{13}{*}{$\begin{array}{l}\text { one } \\
\text { profile, } \\
\text { up }\end{array}$} \\
\hline & & 13 & 24.7 & 40.2 & 9.4 & 222 & \\
\hline & & 31 & 22.3 & 44.6 & 7.8 & 235 & \\
\hline & & 45 & 21.7 & 44.5 & 7.7 & 220 & \\
\hline & & 80 & 21.1 & 45.8 & 7.5 & 253 & \\
\hline & & $9 \overline{5}$ & 20.8 & 45.7 & 8.0 & 235 & \\
\hline & & 108 & 21.1 & 45.7 & 9.3 & 225 & \\
\hline & & 140 & 20.4 & 45.5 & 9.4 & 236 & \\
\hline & \multirow{5}{*}{$\begin{array}{l}1520- \\
1524\end{array}$} & 4 & 23.7 & 52.7 & 6.5 & 291 & \\
\hline & & 12 & 23.1 & 56.5 & 8.9 & 297 & \\
\hline & & 59 & 19.2 & 53.0 & 8.6 & 261 & \\
\hline & & 104 & 20,0 & 47.5 & 7.4 & 254 & \\
\hline & & 122 & 19.2 & 60.4 & 8.2 & 283 & \\
\hline
\end{tabular}




\begin{tabular}{|c|c|c|c|c|c|c|c|}
\hline Date & Time (PST) & Height $(m)$ & $\operatorname{Iemp}\left(C^{\circ}\right)$ & R.H. (\%) & $\begin{array}{l}\text { Wind } \\
\text { Speed }\left(\mathrm{ms}^{-1}\right)\end{array}$ & $\begin{array}{l}\text { Wind } \\
\text { Direct. }(\%)\end{array}$ & Comment \\
\hline \multirow[t]{20}{*}{24 June } & \multirow{11}{*}{$\begin{array}{l}1512- \\
1518\end{array}$} & 5 & 25.9 & 39.5 & 4.0 & 230 & \multirow{11}{*}{$\begin{array}{l}\text { one } \\
\text { profile, } \\
\text { up mode }\end{array}$} \\
\hline & & 10 & 25.0 & 35.0 & 6.1 & 233 & \\
\hline & & 17 & 23.0 & 42.6 & 7.9 & 245 & \\
\hline & & 30 & 21.8 & 40.4 & 8.8 & 242 & \\
\hline & & 45 & 21.5 & 38.2 & 7.6 & 249 & \\
\hline & & 55 & 21.3 & 39.9 & 7.6 & 256 & \\
\hline & & 70 & 21.3 & 39.5 & 7.4 & 240 & \\
\hline & & 98 & 21.3 & 38.8 & 7.3 & 260 & \\
\hline & & 115 & 20.5 & 40.5 & 6.8 & 279 & \\
\hline & & 140 & 20.5 & 42.9 & 6.0 & 215 & \\
\hline & & 165 & 20.6 & 41.9 & 7.4 & 231 & \\
\hline & \multirow{9}{*}{$\begin{array}{l}1707- \\
1738\end{array}$} & 2 & 24.6 & 40.4 & 3.0 & 235 & \multirow{9}{*}{$\begin{array}{l}\text { two } \\
\text { profiles } \\
\text { combined } \\
\text { some down } \\
\text { time for } \\
\text { battery } \\
\text { change. }\end{array}$} \\
\hline & & 20 & 23.0 & 38.0 & 8.9 & 285 & \\
\hline & & 48 & 22.2 & 34.0 & 8.2 & 277 & \\
\hline & & 62 & 22.1 & 33.5 & 9.2 & 306 & \\
\hline & & 88 & 21.9 & 33.6 & 8.2 & 302 & \\
\hline & & 115 & 21.5 & 34.5 & 9.2 & 298 & \\
\hline & & 140 & 21.3 & 34.7 & 8.7 & 282 & \\
\hline & & 175 & 21.0 & 35.7 & 8.8 & 287 & \\
\hline & & 210 & 20.8 & 36.3 & 8.3 & 280 & \\
\hline
\end{tabular}




\section{APPENDIX D}

SUMMARY OF CALFRAN DROPLET DATA 
Table DI. Supplementary drift emission data derived from the Calfran measurements on the Pittsburg

Cooling Towers during July 1978

\begin{tabular}{|c|c|c|c|c|c|c|c|c|c|c|}
\hline \multirow{2}{*}{\multicolumn{2}{|c|}{ Diameter }} & \multicolumn{3}{|c|}{ Date $\quad 7-20$} & \multicolumn{3}{|c|}{ Date $7-20$} & \multicolumn{3}{|c|}{ Date $7-20$} \\
\hline & & \multicolumn{2}{|r|}{ Position } & $\mathrm{A}$ & \multicolumn{2}{|r|}{ Position } & B & \multicolumn{2}{|c|}{ Position } & \multirow{2}{*}{ 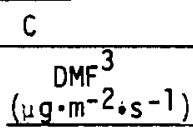 } \\
\hline $\begin{array}{r}\text { Lower } \\
(\mu \mathrm{m}) \\
\end{array}$ & $\begin{array}{r}\text { Upper } \\
(\mu \mathrm{m}) \\
\end{array}$ & $\Delta N^{\top}$ & $\begin{array}{c}\Delta m^{2} \\
\left(\mu \mathrm{g} \cdot m^{-3}\right) \\
\end{array}$ & $\begin{array}{c}D^{D M F} \\
\left(\mu \mathrm{g} \cdot \mathrm{m}^{-2} \cdot \mathrm{s}^{-1}\right) \\
\end{array}$ & $\Delta N^{\top}$ & $\begin{array}{c}\Delta m^{2} \\
\left(\mu g \cdot m^{-3}\right) \\
\end{array}$ & $\begin{array}{c}D M F^{3} \\
\left(\mu g \cdot m^{-2} \cdot s^{-1}\right) \\
\end{array}$ & $\Delta N^{1}$ & $\begin{array}{c}\Delta m^{2} \\
(\mu g \cdot m-3)\end{array}$ & \\
\hline 100 & 200 & & & & & & & & & \\
\hline 200 & 300 & 1 & 3.9 & 29 & 12 & 47 & 518 & 2 & 7.9 & 23.4 \\
\hline 300 & 400 & 8 & 86 & 596 & 44 & 475 & 4990 & 1 & 10.8 & 27.0 \\
\hline 400 & 500 & 2 & 46 & 298 & 43 & 986 & 9960 & 1 & 22.9 & 48.2 \\
\hline 500 & 600 & 6 & 251 & 1550 & 33 & 1380 & 13500 & & & \\
\hline 600 & 700 & 1 & 69 & 394 & $20^{\circ}$ & 1380 & 12900 & & & \\
\hline 700 & 800 & 3 & 319 & 1690 & 14 & 1490 & 13200 & & & \\
\hline 800 & 900 & 4 & 618 & 3030 & 19 & 2940 & 25000 & & & \\
\hline 900 & 1000 & 0 & 0 & 0 & 7 & 1510 & 12200 & & & \\
\hline 1000 & 1200 & 2 & 674 & 1780 & 18 & 6440 & 49300 & & & \\
\hline 1200 & 1400 & 1 & 619 & 2040 & 8 & 4450 & 31300 & & & \\
\hline 1400 & 1600 & & & & 8 & 6310 & 42100 & & & \\
\hline 1600 & 1800 & & & & 4 & 4960 & 29900 & & & \\
\hline 1800 & 2000 & & & & 3 & 5320 & 29600 & & & \\
\hline 2000 & 2200 & & & & 6 & 13700 & 71500 & & & \\
\hline 2200 & 2400 & & & & 1 & 3270 & 15400 & & & \\
\hline 2400 & 2600 & & & & 3 & 12500 & 53800 & & & \\
\hline 2600 & 2800 & & & & 1 & 4680 & 19200 & & & \\
\hline 2800 & 3000 & & & & 1 & 6460 & 22600 & & & \\
\hline 3000 & 3200 & & & & 0 & 0 & 0 & & & \\
\hline 3200 & 3400 & & & & 1 & 9460 & 25600 & & & \\
\hline TOTA & & 28 & 2690 & 12400 & 248 & 87800 & 483000 & 4 & 41.6 & 98.6 \\
\hline
\end{tabular}

\footnotetext{
$1_{\Delta N}=$ Total droplet count

${ }^{2} \mathrm{sm}=$ Total drift mass concentration or density

$3_{\text {DMF }}=$ Drift mass flux
} 
Table D1. (Continued)

\begin{tabular}{|c|c|c|c|c|c|c|c|c|c|c|}
\hline \multirow{2}{*}{\multicolumn{2}{|c|}{ Diarneter }} & \multicolumn{3}{|c|}{ Date $7-21$} & \multicolumn{3}{|c|}{ Date $Z-2]$} & \multicolumn{3}{|c|}{ Date $7-21$} \\
\hline & & \multicolumn{3}{|c|}{ Position A } & \multicolumn{3}{|c|}{ Position B } & \multicolumn{3}{|c|}{ Position $C$} \\
\hline $\begin{array}{l}\text { Lower } \\
(\mu \mathrm{m})\end{array}$ & $\begin{array}{l}\text { Upper } \\
(\mathrm{Lm}) \\
\end{array}$ & $\Delta N^{\top}$ & $\begin{array}{c}\Delta m^{2} \\
\left(\mu g \cdot m^{-3}\right)\end{array}$ & $\begin{array}{c}D^{*} \cdot F^{3} \\
\left(\mu g \cdot m^{-2} \cdot s^{-1}\right)\end{array}$ & $\Delta N^{1}$ & $\frac{i m^{2}}{\left(n g \cdot m^{-3}\right)}$ & $\begin{array}{c}\mathrm{DMF}^{3} \\
\left(\mu \mathrm{g} \cdot \mathrm{m}^{-2} \cdot \mathrm{s}^{-1}\right) \\
\end{array}$ & $\Delta N^{\top}$ & $\begin{array}{c}\Delta m^{2} \\
(-g \cdot m-3)\end{array}$ & $\begin{array}{c}D M F^{3} \\
\left(\mu \mathrm{g} \cdot \mathrm{m}^{-2} \cdot \mathrm{s}^{-1}\right)\end{array}$ \\
\hline 100 & 200 & & & & & & & & & \\
\hline 200 & 300 & 2 & 12 & 87 & 12 & 71 & 778 & 3 & 18 & 53 \\
\hline 300 & 400 & 4 & 65 & 447 & 30 & 486 & 5110 & 0 & 0 & 0 \\
\hline 400 & 500 & 1 & 34 & 224 & 10 & 344 & 3480 & 0 & 0 & 0 \\
\hline 500 & 600 & 0 & 0 & 0 & 5 & 314 & 3070 & 1 & 63 & 110 \\
\hline 600 & 700 & 0 & 0 & 0 & 10 & 1040 & 9660 & & & \\
\hline 700 & 800 & 1 & 159 & 845 & 9 & 1440 & 12800 & & & \\
\hline 800 & 900 & & & & 3 & 197 & 5920 & & & \\
\hline 900 & 1000 & & & & 5 & 1620 & 13100 & & & \\
\hline 1000 & 1200 & & & & 4 & 2025 & 15700 & & & \\
\hline 1200 & 1400 & & & & 2 & 1670 & 11700 & & & \\
\hline 1400 & 1600 & & & & 4 & 4470 & 32400 & & & \\
\hline 1600 & 1800 & & & & 0 & 0 & 0 & & & \\
\hline 1800 & 2000 & & & & 1 & 2800 & 15400 & & & \\
\hline 2000 & 2200 & & & & 0 & 0 & 0 & & & \\
\hline 2200 & 2400 & & & & 2 & 8610 & 42200 & & & \\
\hline 2400 & 2600 & & & & 0 & 0 & 0 & & & \\
\hline 2600 & 2800 & & & & 1 & 7860 & 30700 & & & \\
\hline 2800 & 3000 & & & & 0 & 0 & 0 & & & \\
\hline 3000 & 3200 & & & & 0 & 0 & 0 & & & \\
\hline 3200 & 3400 & & & & 1 & 13000 & 37600 & & & \\
\hline & OTALS & 8 & 271 & 1600 & 99 & 46800 & 240000 & 4 & 81 & 163 \\
\hline
\end{tabular}


Table DI. (Continued)

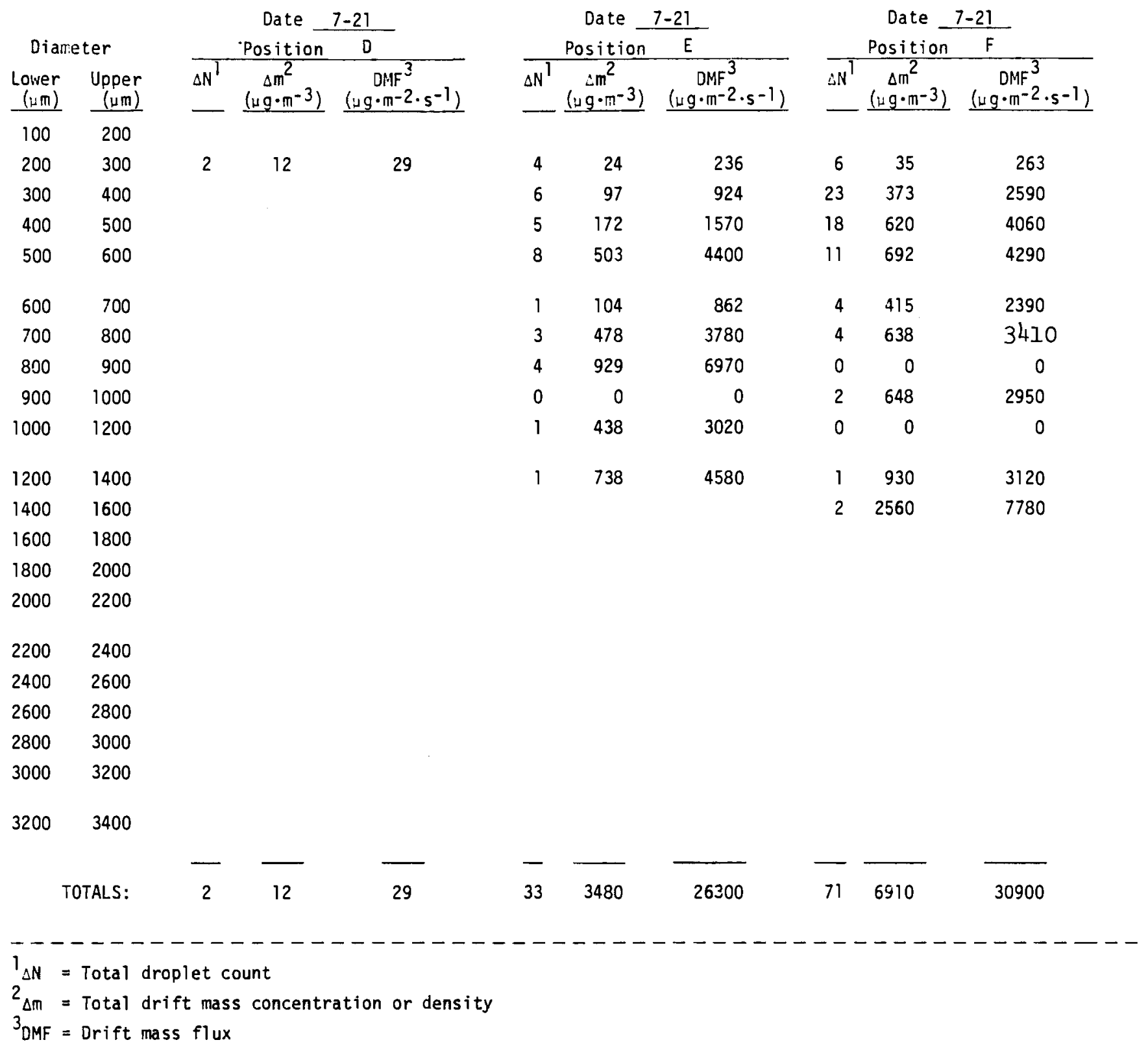


Table D1. (Continued)

\begin{tabular}{|c|c|c|c|c|c|c|c|c|c|c|}
\hline \multirow{2}{*}{\multicolumn{2}{|c|}{ Diameter }} & \multicolumn{3}{|c|}{ Date $7-22$} & \multicolumn{3}{|c|}{ Date $7-22$} & \multicolumn{3}{|c|}{ Date 7-22 } \\
\hline & & \multicolumn{2}{|r|}{ Position } & A & \multicolumn{2}{|r|}{ Position } & B & \multicolumn{2}{|r|}{ Position } & $C$ \\
\hline $\begin{array}{r}\text { Lower } \\
(\mu \mathrm{m}) \\
\end{array}$ & $\begin{array}{r}\text { Upper } \\
(\mu \mathrm{m}) \\
\end{array}$ & $\Delta N^{\top}$ & $\left(\mu \mathrm{g} \cdot \mathrm{m}^{2}-3\right)$ & $\begin{array}{c}D H F^{3} \\
\left(\mu \mathrm{g} \cdot \mathrm{m}^{-2} \cdot \mathrm{s}^{-1}\right) \\
\end{array}$ & $\Delta N^{1}$ & $\begin{array}{c}\Delta m^{2} \\
\left(u g \cdot m^{-3}\right) \\
\end{array}$ & $\begin{array}{c}\quad \operatorname{DMF}^{3} \\
\left(\mu \mathrm{g} \cdot \mathrm{m}^{-2} \cdot \mathrm{s}^{-1}\right) \\
\end{array}$ & $\Delta N^{\prime}$ & $\begin{array}{c}\Delta m^{2} \\
\left(\mu g \cdot m^{-3}\right) \\
\end{array}$ & $\begin{array}{c}O M F^{3} \\
\left(\mathrm{ug} \cdot \mathrm{m}^{-2} \cdot \mathrm{s}^{-1}\right)\end{array}$ \\
\hline 100 & 200 & & & & & & & & & \\
\hline 200 & 300 & & & & 7 & 41 & 454 & & & \\
\hline 300 & 400 & 1 & 16 & 112 & 16 & 259 & 2720 & 3 & 49 & 122 \\
\hline 400 & 500 & 2 & 69 & 448 & 18 & 620 & 6260 & & & \\
\hline 500 & 600 & 3 & 189 & 1160 & 6 & 377 & 3680 & & & \\
\hline 600 & 700 & & & & 7 & 727 & 6760 & & & \\
\hline 700 & 800 & & & & 5 & 797 & 7100 & & & \\
\hline 800 & 900 & & & & 2 & 464 & 3950 & & & \\
\hline 900 & 1000 & & & & 0 & 0 & 0 & & & \\
\hline 1000 & 1200 & & & & 1 & 575 & 4370 & & & \\
\hline 1200 & 1400 & & & & 1 & 930 & 6420 & & & \\
\hline 1400 & 1600 & & & & 1 & 1410 & 9150 & & & \\
\hline 1600 & 1800 & & & & 4 & 7450 & 45000 & & & \\
\hline 1800 & 2000 & & & & 2 & 5190 & 29000 & & & \\
\hline 2000 & 2200 & & & & 1 & 3760 & 19200 & & & \\
\hline 2200 & 2400 & & & & 2 & 9810 & 46100 & & & \\
\hline 2400 & 2600 & & & & & & & & & \\
\hline 2600 & 2800 & & & & & & & & & \\
\hline 2800 & 3000 & & & & & & & & & \\
\hline 3000 & 3200 & & & & & & & & & \\
\hline 3200 & 3400 & & & & & & & & & \\
\hline & & - & 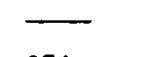 & & $\overline{2}$ & $\bar{L}$ & & 5 & - & \\
\hline TO & LS: & 6 & 274 & 1720 & 73 & 32400 & 190000 & 3 & 49 & 122 \\
\hline
\end{tabular}

$1_{\Delta N}=$ Total droplet count

$2_{\Delta m}=$ Total drift mass concentration or density

$3_{\text {DMF }}=$ Drift mass flux 
Takle DI, (Continued)

\begin{tabular}{|c|c|c|c|c|c|c|c|c|c|c|}
\hline \multirow{2}{*}{\multicolumn{2}{|c|}{ Diameter }} & \multicolumn{3}{|c|}{ Date 7-22 } & \multicolumn{3}{|c|}{ Date $7-22$} & \multicolumn{3}{|c|}{ Date $7-22$} \\
\hline & & \multicolumn{2}{|c|}{ Position } & \multirow{2}{*}{$\begin{array}{l}D \\
\begin{array}{c}D M F^{3} \\
\left(\mu \mathrm{g} \cdot \mathrm{m}^{-2} \cdot \mathrm{s}^{-1}\right)\end{array}\end{array}$} & \multicolumn{3}{|c|}{ Position $\mathrm{E}$} & \multicolumn{3}{|c|}{ Position $F$} \\
\hline $\begin{array}{r}\text { Lower } \\
(\mu \mathrm{m}) \\
\end{array}$ & $\begin{array}{l}\text { Upper } \\
(\mu \mathrm{m}) \\
\end{array}$ & $\Delta N^{1}$ & $\begin{array}{c}\Delta \mathrm{m}^{2} \\
\left(\mu \mathrm{g} \cdot \mathrm{m}^{-3}\right) \\
\end{array}$ & & $\Delta N^{1}$ & $\begin{array}{c}\Delta m^{2} \\
\left(\mu \mathrm{g} \cdot \mathrm{m}^{-3}\right) \\
\end{array}$ & $\begin{array}{c}\mathrm{DMF} \\
\left(\mu \mathrm{g} \cdot \mathrm{m}^{-2} \cdot \mathrm{s}^{-1}\right) \\
\end{array}$ & $\mathrm{SN}^{\mathrm{T}}$ & $\begin{array}{c}\mathrm{cm}^{2} \\
\left(\mu \mathrm{g} \cdot \mathrm{m}^{-3}\right)\end{array}$ & $\begin{array}{c}\mathrm{DMF}^{3} \\
\left(\mathrm{Lg} \cdot \mathrm{m}^{-2} \cdot \mathrm{s}^{-1}\right)\end{array}$ \\
\hline 100 & 200 & & & & & & & & & \\
\hline 200 & 300 & 1 & 5.9 & 14.4 & 1 & 5.9 & 59 & 8 & 47 & 351 \\
\hline 300 & 400 & & & & 5 & 81 & 770 & 30 & 486 & 3380 \\
\hline 400 & 500 & & & & 7 & 241 & 2190 & 26 & 896 & 5870 \\
\hline 500 & 600 & & & & 2 & 126 & 1100 & 9 & 565 & 3510 \\
\hline 600 & 700 & & & & 2 & 208 & 1720 & 7 & 727 & 4180 \\
\hline 700 & 800 & & & & 1 & 159 & 1260 & 4 & 638 & 3410 \\
\hline 800 & 900 & & & & 0 & 0 & 0 & 5 & 1160 & 5750 \\
\hline 900 & 1000 & & & & 2 & 648 & 4600 & 1 & 324 & 1470 \\
\hline 1000 & 1200 & & & & - & - & -- & 1 & 438 & 1900 \\
\hline 1200 & 1400 & & & & - & - & -- & & & \\
\hline 1400 & 1600 & & & & - & - & -- & & & \\
\hline 1600 & 1800 & & & & - & - & -- & & & \\
\hline 1800 & 2000 & & & & - & - & -- & & & \\
\hline 2000 & 2200 & & & & - & - & -- & & & \\
\hline 2200 & 2400 & & & & 1 & 4910 & 18200 & & & \\
\hline 2400 & 2600 & & & & & & & & & \\
\hline 2600 & 2800 & & & & & & & & & \\
\hline 2800 & 3000 & & & & & & & & & \\
\hline 3000 & 3200 & & & & & & & & & \\
\hline 3200 & 3400 & & & & & & & & & \\
\hline & & $\bar{T}$ & 50 & $\overline{14}$ & $\overline{21}$ & $\overline{6380}$ & $\overline{200 n}$ & - & $\overline{5}$ & $\bar{E}$ \\
\hline & ALS: & 1 & 5.9 & 14.4 & 21 & 6380 & 29,900 & 91 & 5280 & 59700 \\
\hline
\end{tabular}

- - - - - - - - - - - - - - - - - - - - - - - - - - - - - - - - - -

$1_{\Delta N}=$ Total droplet count

${ }^{2} \Delta m=$ Total drift mass concentration or density

${ }^{3}$ DMF $=$ Drift mass flux

D-5 
Table DI. (Continued)

\begin{tabular}{|c|c|c|c|c|c|c|c|c|c|}
\hline \multirow{2}{*}{\multicolumn{2}{|c|}{ Diameter }} & \multicolumn{3}{|c|}{ Date $7-25$} & \multicolumn{3}{|c|}{ Date $7-26$} & \multirow{2}{*}{\multicolumn{2}{|c|}{$\begin{array}{c}\text { Date } \\
\text { Position }\end{array}$}} \\
\hline & & \multicolumn{2}{|r|}{ Position } & & \multicolumn{2}{|r|}{ Position } & $\mathrm{B}$ & & \\
\hline $\begin{array}{l}\text { Lower } \\
(\mathrm{m})\end{array}$ & $\begin{array}{r}\text { Upper } \\
(1 \pm n) \\
\end{array}$ & $\Delta N^{1}$ & $\begin{array}{c}\Delta m^{2} \\
\left(\mu g \cdot m^{-3}\right) \\
\end{array}$ & $\begin{array}{c}\mathrm{CMF}^{3} \\
\left(\mu \mathrm{g} \cdot \mathrm{m}^{-2} \cdot \mathrm{s}^{-1}\right) \\
\end{array}$ & $\Delta N^{1}$ & $\begin{array}{c}\Delta m^{2} \\
\left(\mu g \cdot m^{-3}\right) \\
\end{array}$ & $\begin{array}{c}\mathrm{DMF} \mathrm{F}^{3} \\
\left(\mu \mathrm{g} \cdot \mathrm{m}^{-2} \cdot \mathrm{s}^{-1}\right) \\
\end{array}$ & $\begin{array}{cc}\Delta N^{1} & \Delta m^{2} \\
\left(\mu g \cdot m^{-3}\right) \\
\end{array}$ & $\begin{array}{c}\mathrm{DMF}^{3} \\
\left(\mathrm{~g} \cdot \mathrm{m}^{-2} \cdot \mathrm{s}^{-1}\right) \\
\end{array}$ \\
\hline 100 & 200 & 34 & 28 & 323 & 32 & 27 & 304 & & \\
\hline 200 & 300 & 16 & 62 & 675 & 37 & 142 & 1560 & & \\
\hline 300 & 400 & 2 & $2 i$ & 221 & 14 & 148 & 1550 & & \\
\hline 400 & 500 & 2 & 45 & 452 & 8 & 179 & 1810 & & \\
\hline 500 & 600 & 0 & 0 & 0 & 4 & 164 & 1600 & & \\
\hline 600 & 700 & 2 & 135 & 1260 & 0 & 0 & 0 & & \\
\hline 700 & 800 & 2 & 207 & 1850 & 4 & 415 & 3690 & & \\
\hline 800 & 900 & 2 & 302 & 2570 & 0 & 0 & 0 & & \\
\hline 900 & 1000 & 5 & 1050 & 8540 & 1 & 211 & 1710 & & \\
\hline 1000 & 1200 & 0 & 0 & 0 & 2 & 748 & 5680 & & \\
\hline 1200 & 1400 & 0 & 0 & 0 & 2 & 1085 & 7630 & & \\
\hline 1400 & 1600 & 1 & 749 & 5020 & 0 & 0 & 0 & & \\
\hline 1600 & 1800 & 1 & 1320 & 7770 & 0 & 0 & 0 & & \\
\hline 1800 & 2000 & 1 & 1820 & 10000 & 0 & 0 & 0 & & \\
\hline 2000 & 2200 & & & & 1 & 2440 & 12500 & & \\
\hline 2200 & 2400 & & & & & & & & \\
\hline 2400 & 2600 & & & & & & & & \\
\hline 2600 & 2800 & & & & & & & & \\
\hline 2800 & 3000 & & & & & & & & \\
\hline 3000 & 3200 & & & & & & & & \\
\hline 3200 & 3400 & & & & & & & & \\
\hline
\end{tabular}

$\begin{array}{lllllll}\text { TOTALS: } & - & & & & & \\ 71 & 5740 & 38700 & 108 & 5560 & \end{array}$

$1_{\Delta N}=$ Total droplet count

${ }^{2} \Delta m=$ Total drift mass concentration or density

$3_{\text {DMF }}=$ Drift mass flux 
APPENDIX E

DEPOSITION LISTINGS 
TABLE El.1. Drift Droplet Deposition, Test Run 1, 16 June 1978

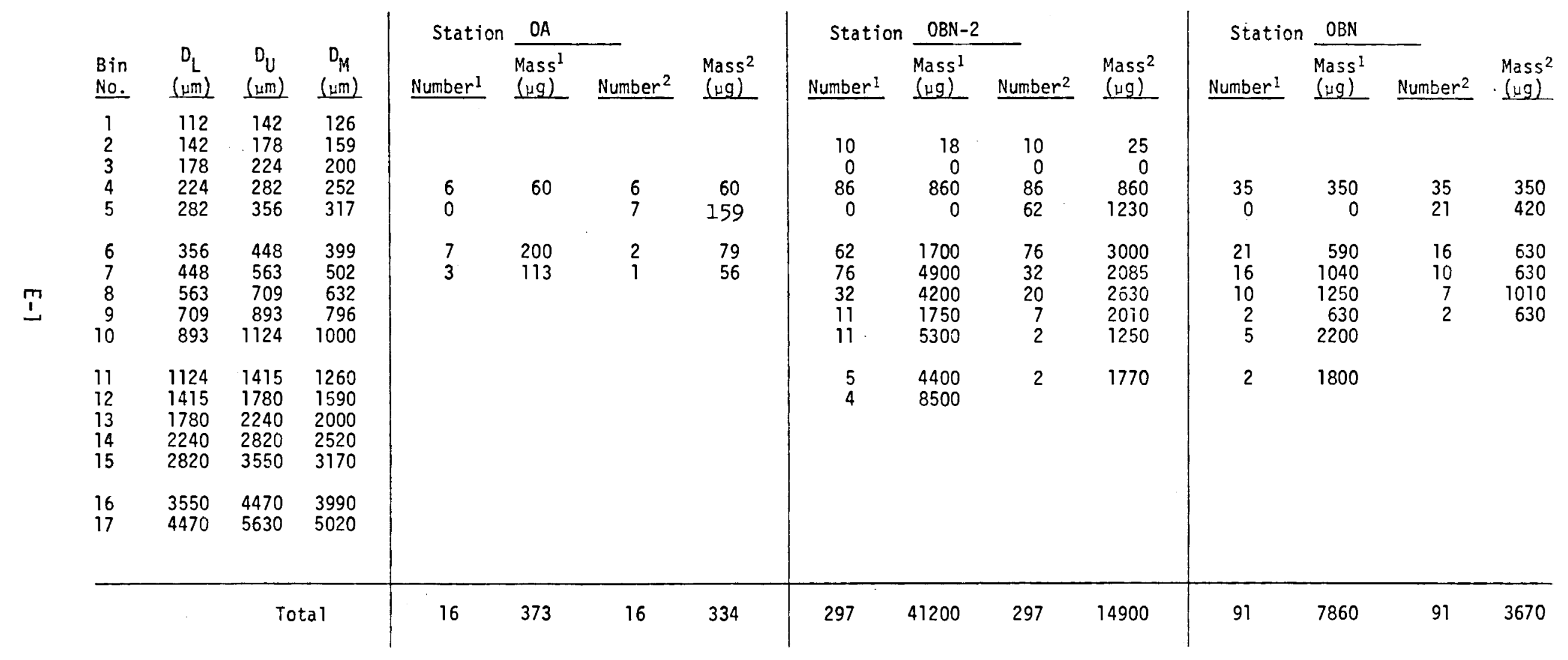

${ }^{1}$ Meyer calibration

${ }^{2}$ ESC calibration plus adjustment 
TABLE ET.1. (Continued)

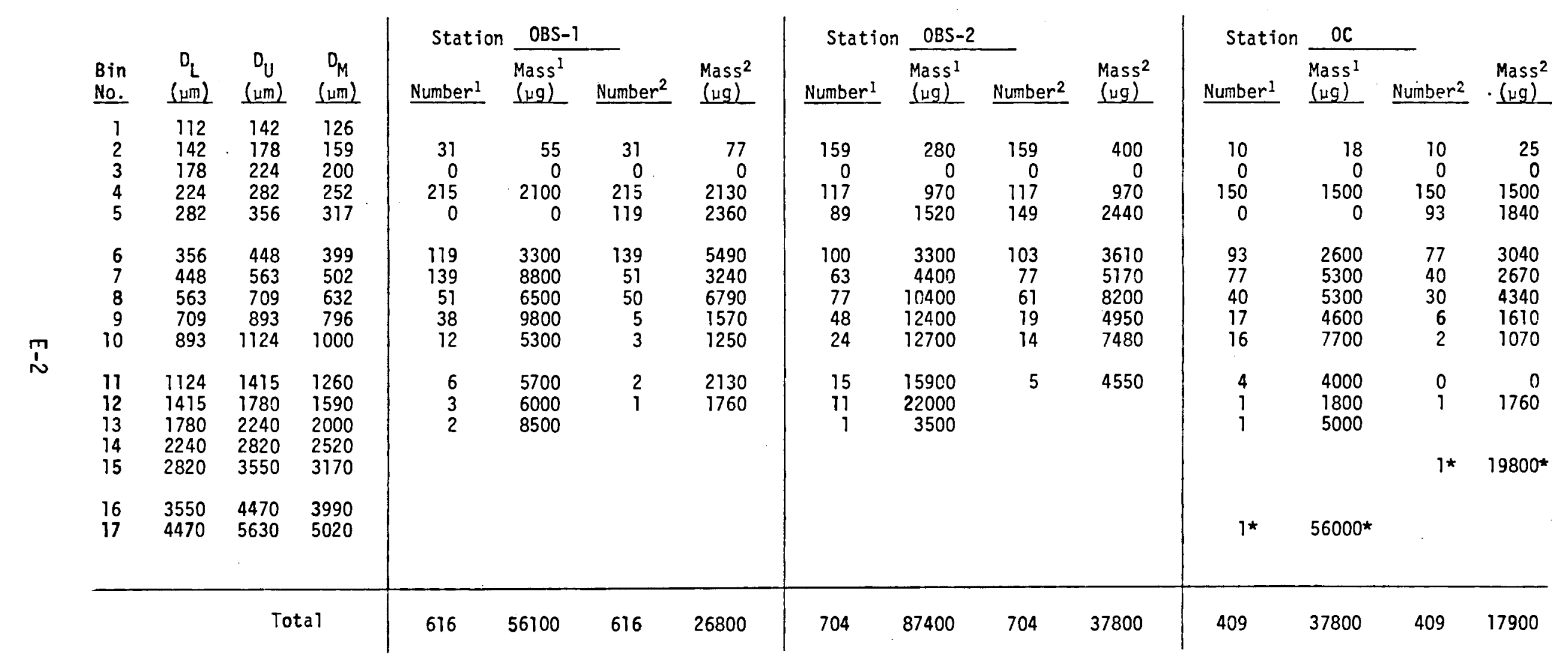

1Meyer calibration

2 ESC calibration plus adjustment

*Not included in total. 
TABLE E1.1. (Continued)

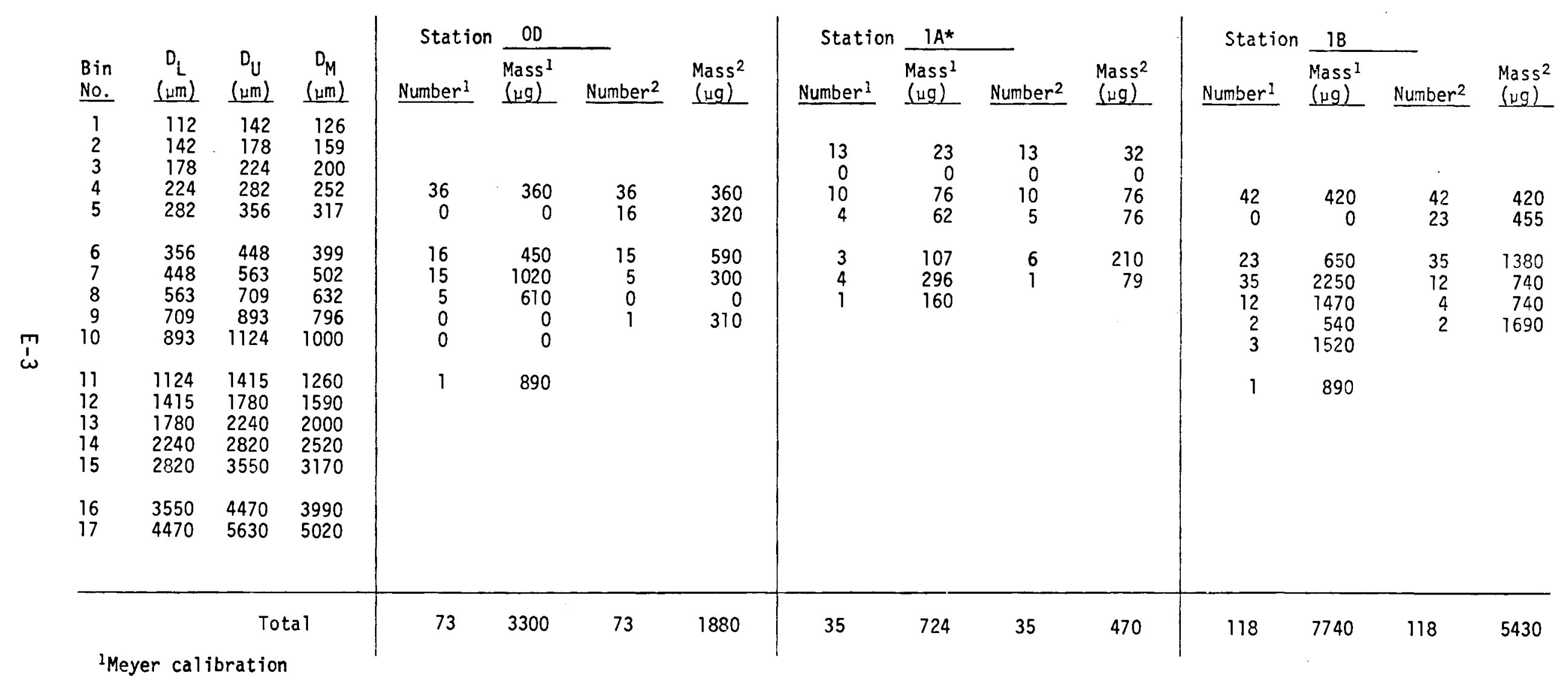

${ }^{2}$ ESC calibration plus adjustment

*Area method 
TABLE EI.1. (Continued)

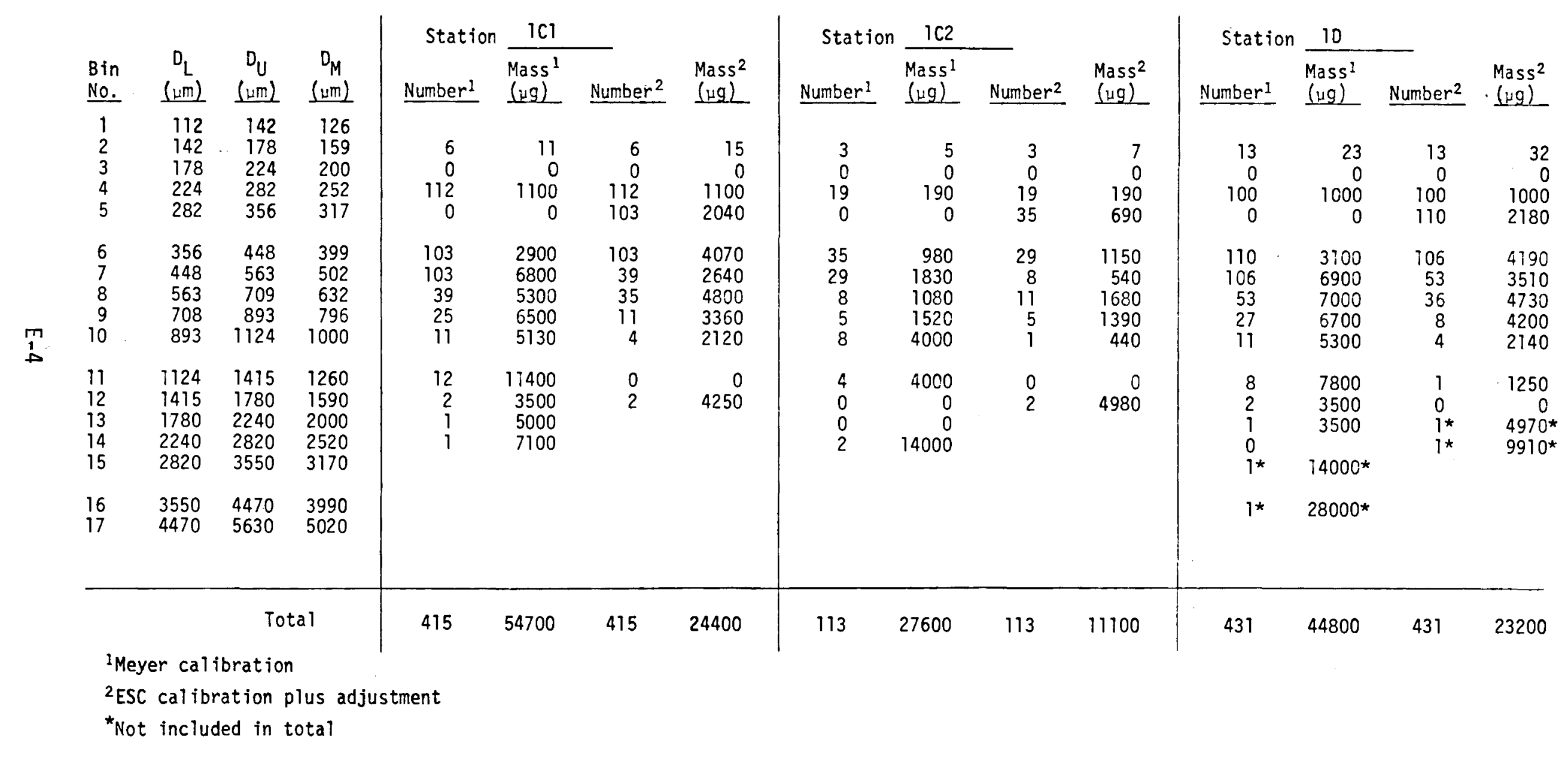


TABLE El.1. (Continued)

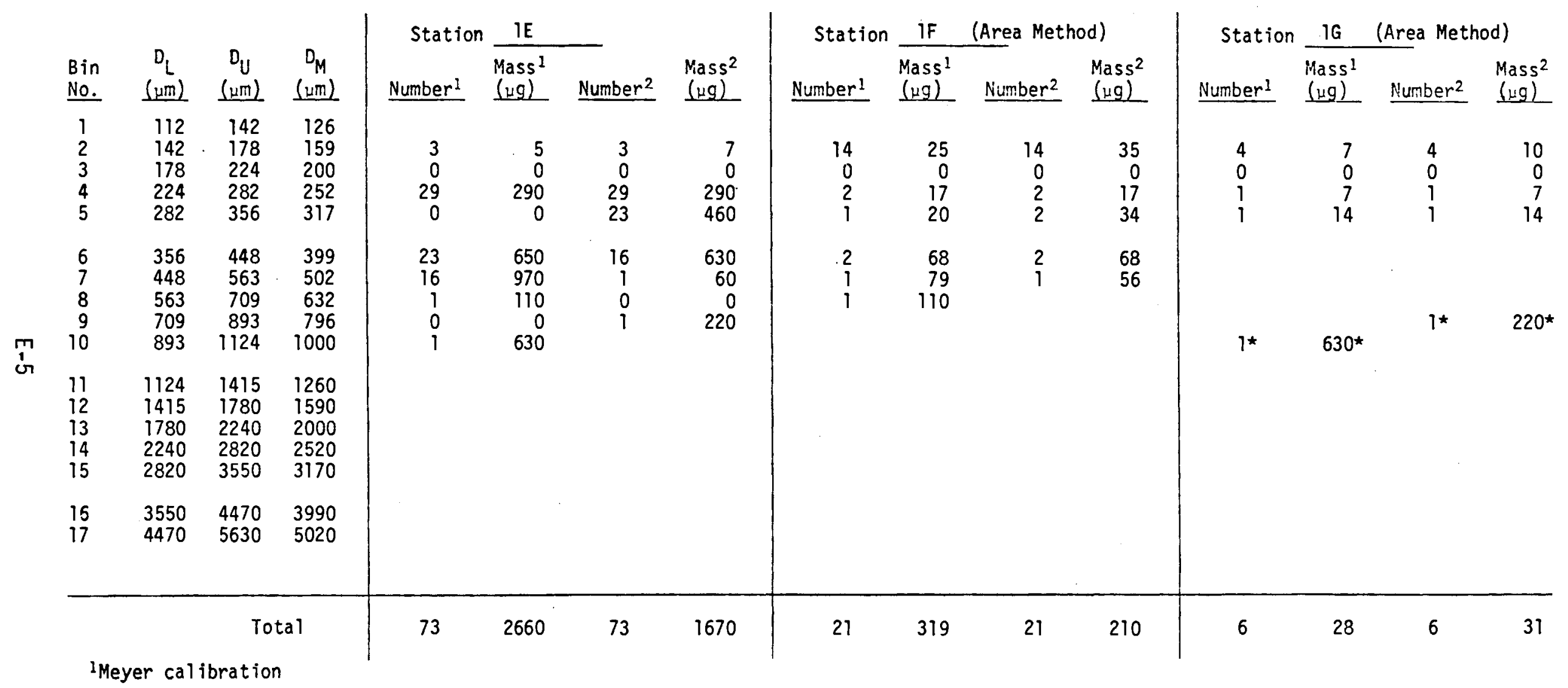

1 Meyer calibration

${ }^{2}$ ESC calibration plus adjustment

* $N$ ot included in total. 
IABLE E1.1. (Continued)

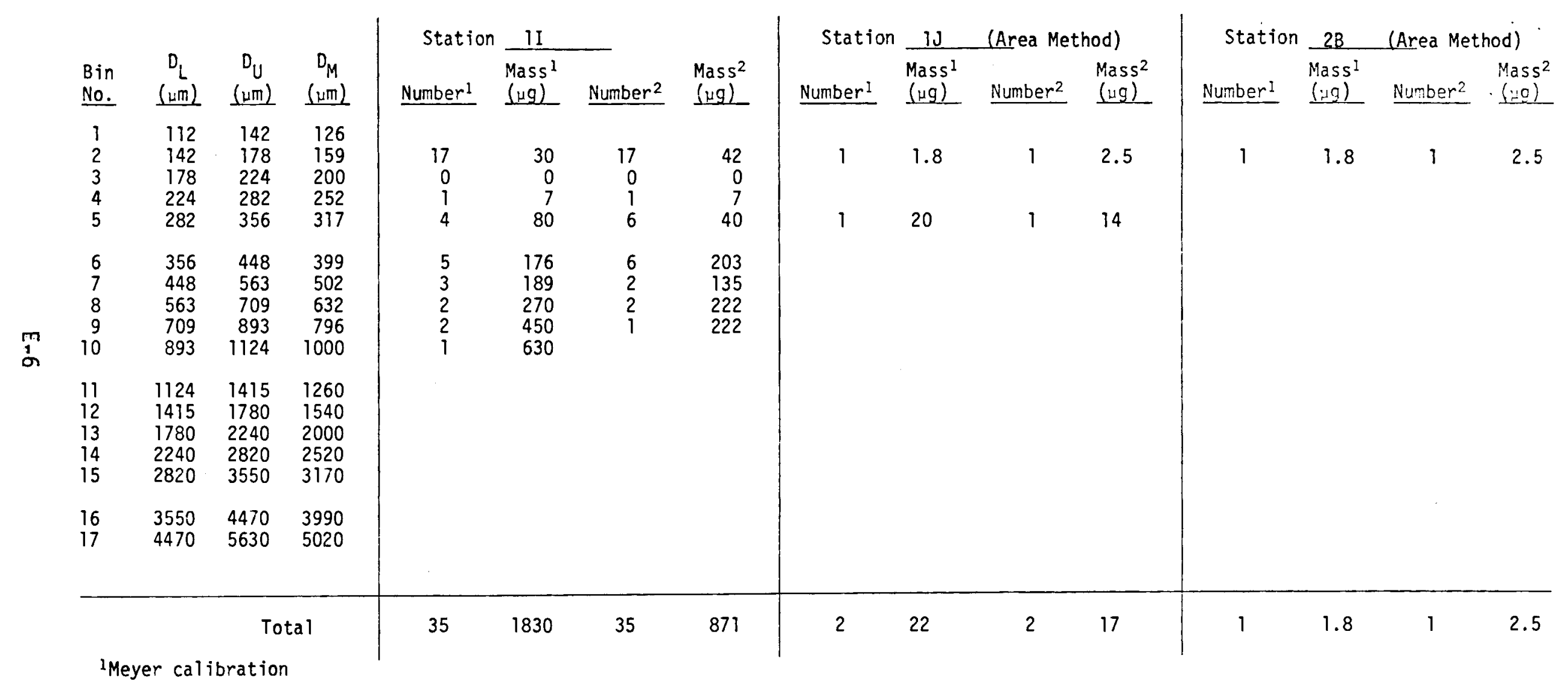

1 Meyer calibration

${ }^{2}$ ESC calibration plus adjustment 


\section{TABLE E1.1. (Continued)}

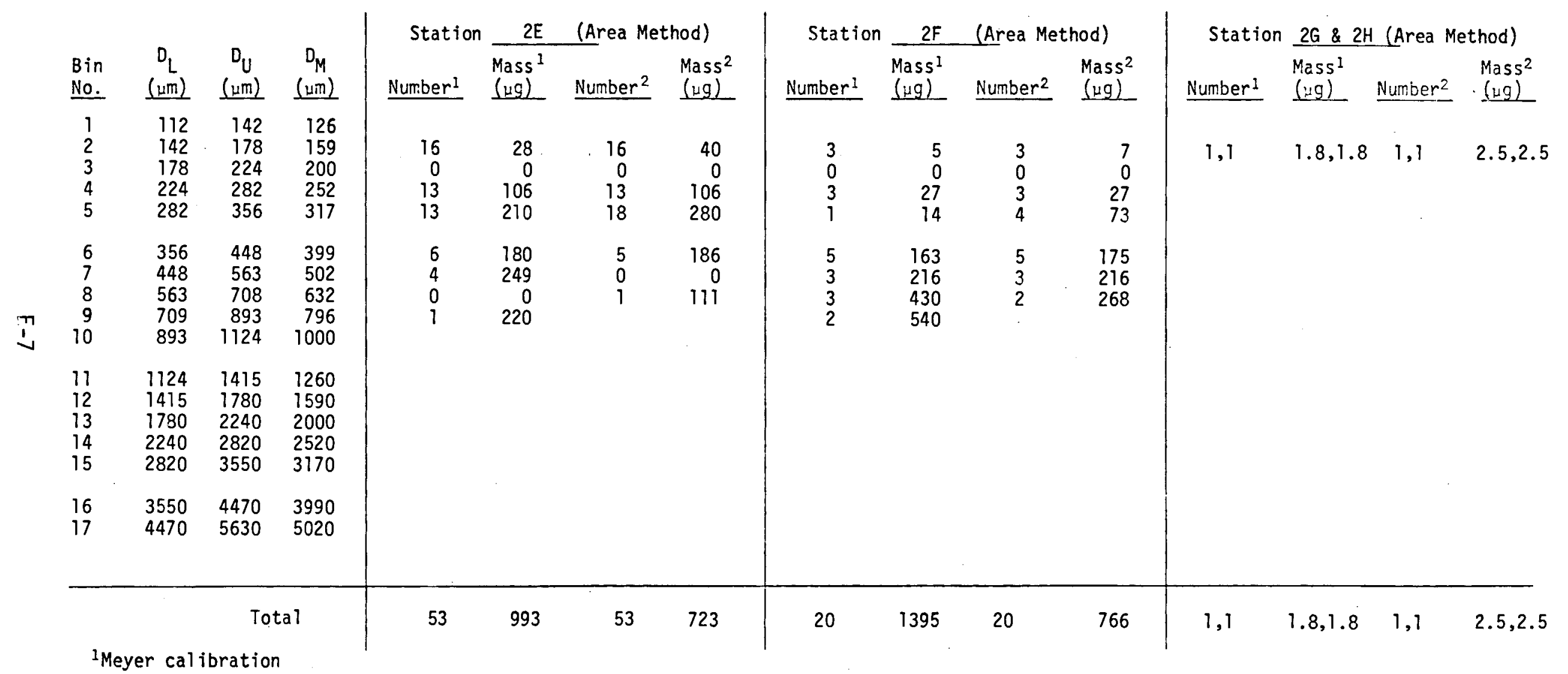

${ }^{1}$ Meyer calibration

${ }^{2}$ ESC calibration 
TABLE E1.1. (Continued)

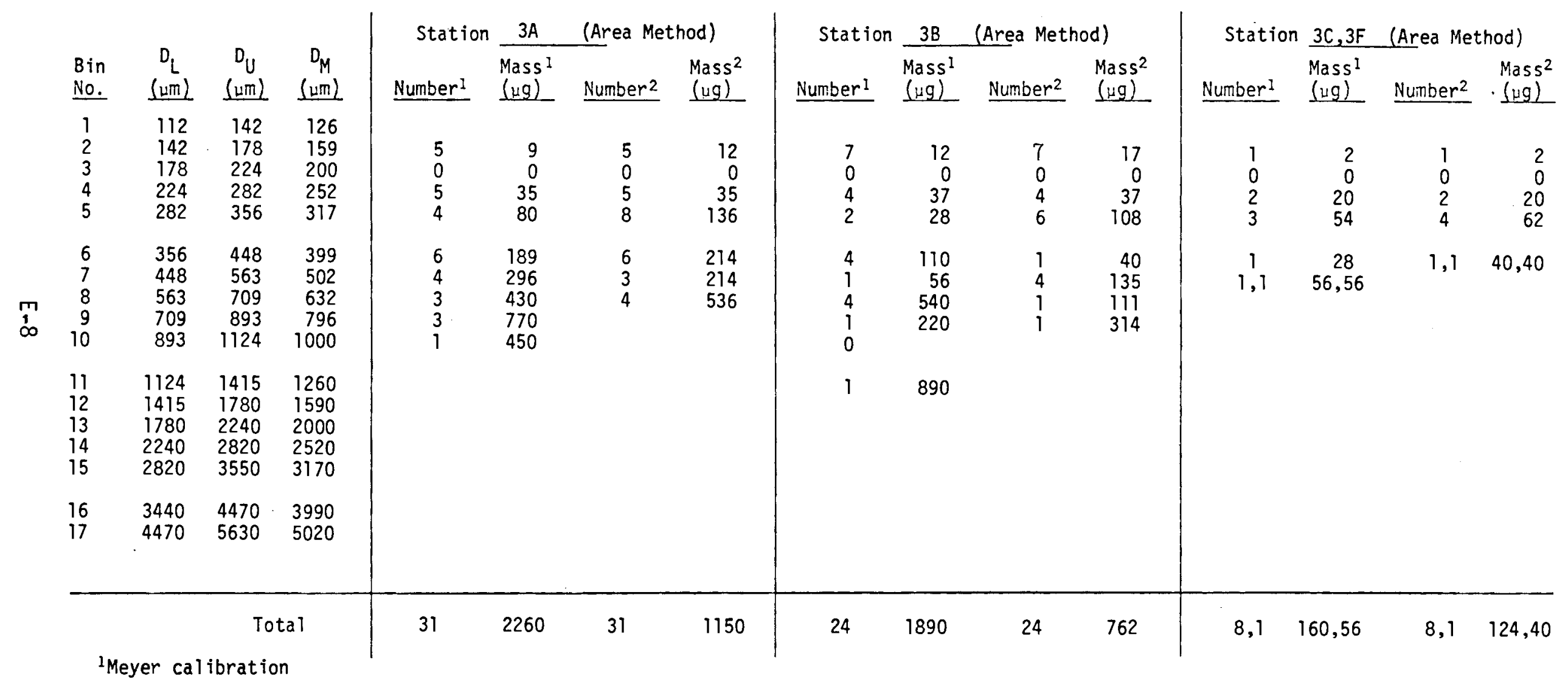

Meyer calibration

${ }^{2}$ ESC calibration plus adjustment 
TABLE El.2. Drift Droplet Deposition Spectra, Test Run 2, 17 June 1978

\begin{tabular}{|c|c|c|c|c|c|c|c|c|c|c|c|c|c|c|c|}
\hline & & & & Station & $O C$ & (Area) & & Station & $10-$ & (Area) & & station & n $10-2$ & (Area) & \\
\hline $\begin{array}{l}\text { Bin } \\
\text { No. }\end{array}$ & $\begin{array}{c}D_{\mathrm{L}} \\
(\mu \mathrm{m})\end{array}$ & $\begin{array}{c}D_{U} \\
(\mu \mathrm{m}) \\
\end{array}$ & $\begin{array}{c}D_{M} \\
(\mu \mathrm{m}) \\
\end{array}$ & & $\begin{array}{l}\text { Mass }{ }^{2} \\
(\mu g)\end{array}$ & Number ${ }^{2}$ & $\begin{array}{c}\text { Mass }^{2} \\
(\mu g)\end{array}$ & Number 1 & $\begin{array}{l}\text { Mass } \\
(\mu \mathrm{g})\end{array}$ & Number ${ }^{2}$ & $\begin{array}{l}\text { Mass }^{2} \\
(\mu \mathrm{g})\end{array}$ & Number & $\begin{array}{l}\text { Mass }{ }^{1} \\
(\mu g)\end{array}$ & Number 2 & $\begin{array}{l}\text { Mass } \\
(\mathrm{ug})\end{array}$ \\
\hline $\begin{array}{l}1 \\
2 \\
3 \\
4 \\
5\end{array}$ & $\begin{array}{l}112 \\
142 \\
178 \\
224 \\
282\end{array}$ & $\begin{array}{l}142 \\
178 \\
224 \\
282 \\
356\end{array}$ & $\begin{array}{l}126 \\
159 \\
200 \\
252 \\
317\end{array}$ & & & & & $\begin{array}{r}173 \\
0 \\
126 \\
78\end{array}$ & $\begin{array}{r}310 \\
0 \\
1050 \\
1360\end{array}$ & $\begin{array}{r}173 \\
0 \\
126 \\
137\end{array}$ & $\begin{array}{r}430 \\
0 \\
1050 \\
2260\end{array}$ & $\begin{array}{r}2 \\
0 \\
31 \\
65\end{array}$ & $\begin{array}{r}5 \\
0 \\
272 \\
830\end{array}$ & $\begin{array}{r}2 \\
31 \\
65\end{array}$ & $\begin{array}{r}7 \\
272 \\
1030\end{array}$ \\
\hline $\begin{array}{r}6 \\
7 \\
8 \\
9 \\
10\end{array}$ & $\begin{array}{l}356 \\
448 \\
563 \\
709 \\
893\end{array}$ & $\begin{array}{r}448 \\
563 \\
709 \\
893 \\
1124\end{array}$ & $\begin{array}{r}399 \\
502 \\
632 \\
796 \\
1000\end{array}$ & $\begin{array}{l}1 \\
1\end{array}$ & $\begin{array}{l}40 \\
56\end{array}$ & 2 & 68 & $\begin{array}{l}94 \\
75 \\
44 \\
26 \\
11\end{array}$ & $\begin{array}{l}3100 \\
5000 \\
5700 \\
6800 \\
5500\end{array}$ & $\begin{array}{r}110 \\
44 \\
34 \\
3 \\
3\end{array}$ & $\begin{array}{r}3940 \\
2850 \\
4650 \\
670 \\
1330\end{array}$ & $\begin{array}{r}45 \\
48 \\
17 \\
18 \\
6\end{array}$ & $\begin{array}{l}1550 \\
3300 \\
2090 \\
4800 \\
3200\end{array}$ & $\begin{array}{r}73 \\
17 \\
21 \\
6\end{array}$ & $\begin{array}{l}2600 \\
1060 \\
2880 \\
1610\end{array}$ \\
\hline $\begin{array}{l}11 \\
12 \\
13 \\
14 \\
15\end{array}$ & $\begin{array}{l}1124 \\
1415 \\
1780 \\
2240 \\
2820\end{array}$ & $\begin{array}{l}1415 \\
1780 \\
2240 \\
2820 \\
3550\end{array}$ & $\begin{array}{l}1260 \\
1590 \\
2000 \\
2520 \\
3170\end{array}$ & & & & & 3 & 3800 & & & 3 & 2700 & & \\
\hline $\begin{array}{l}16 \\
17\end{array}$ & $\begin{array}{l}3550 \\
4470\end{array}$ & $\begin{array}{l}4470 . \\
5630\end{array}$ & $\begin{array}{l}3990 \\
5020\end{array}$ & & & & & & & & & & & & \\
\hline & & To & & 2 & 96 & 2 & 68 & 630 & 32100 & 630 & 17180 & 215 & 18700 & 215 & 9460 \\
\hline
\end{tabular}

2ESC calibration plus adjustment 
TABLE E1.2. (Continued)

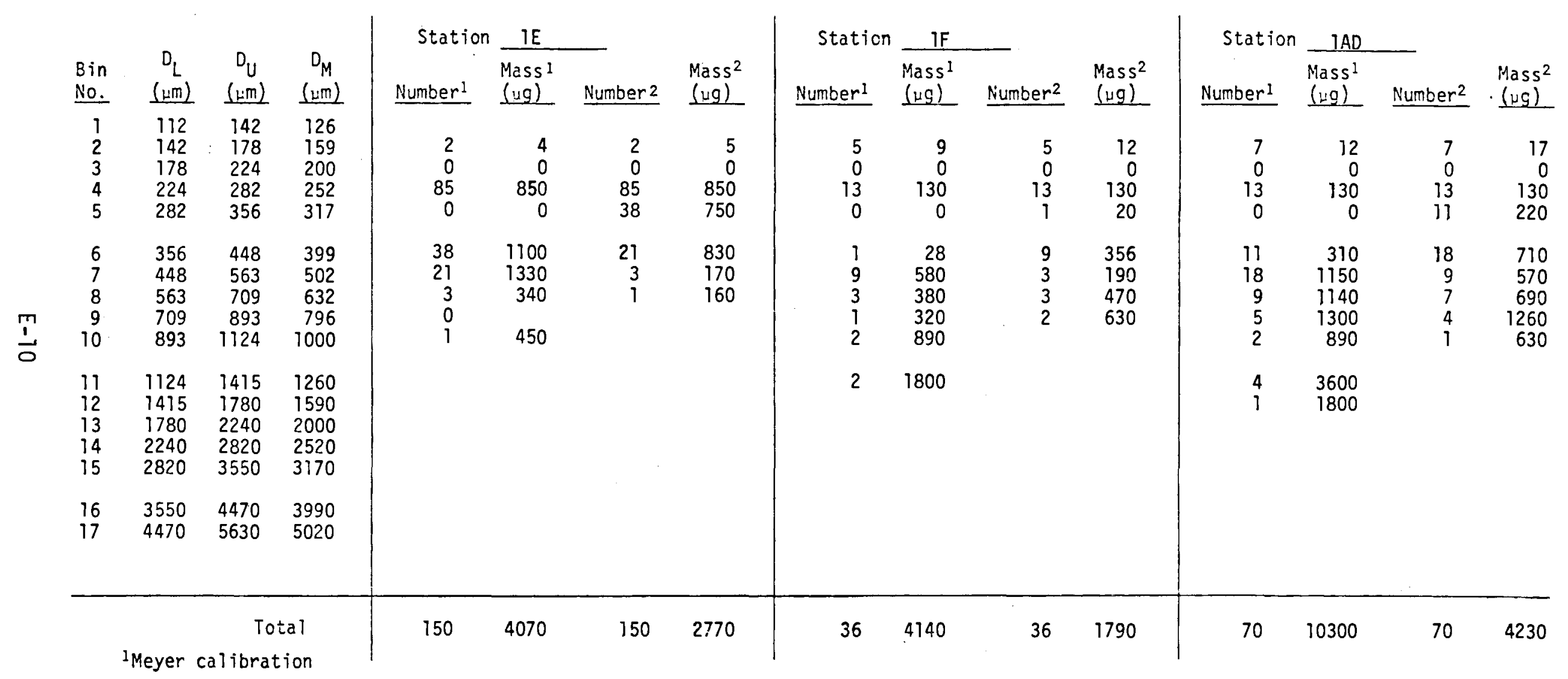

${ }^{2}$ ESC calibration plus adjustment 
TABLE EI.2. (Cont inued)

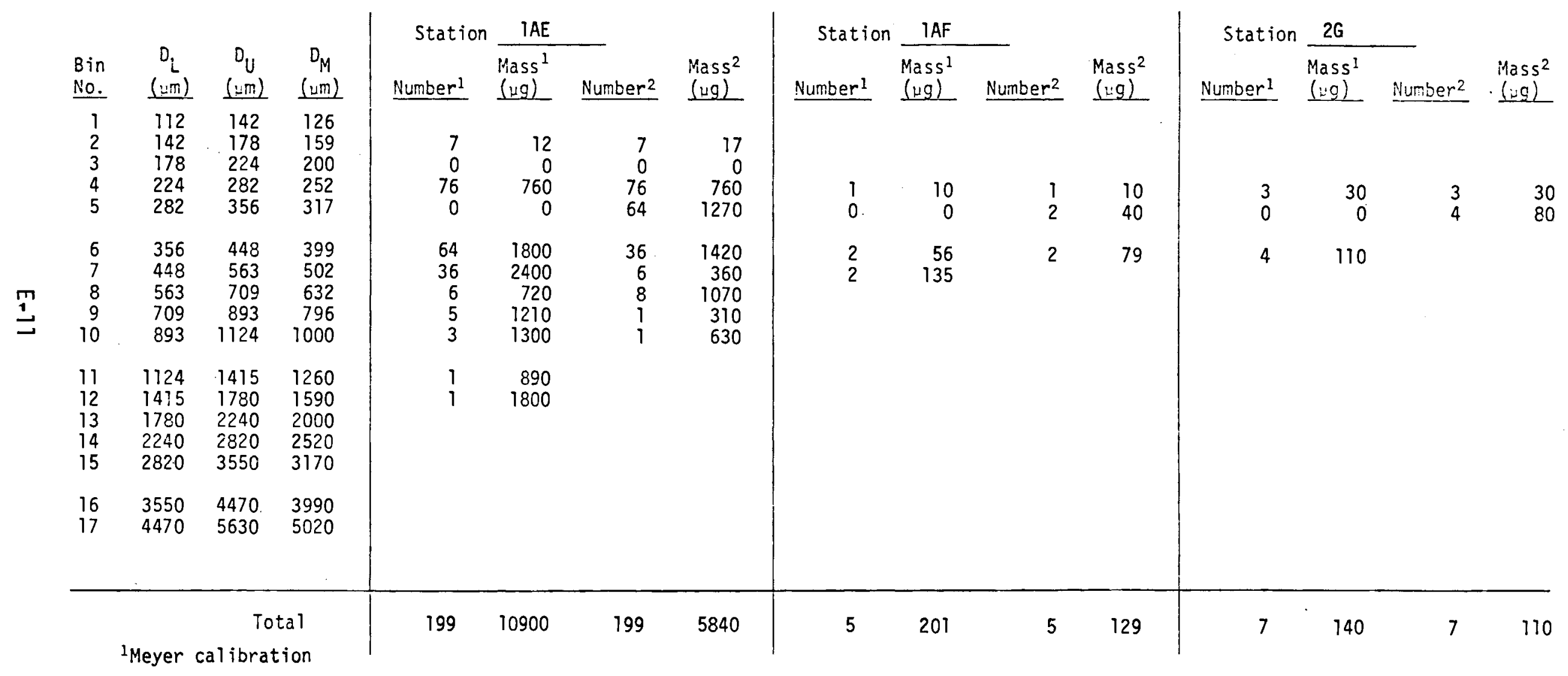

${ }^{2}$ ESC calibration plus adjustment 
TABLE El.3. Drift Droplet Deposition Spectra, Test Run 3, 15 June 1978

\begin{tabular}{|c|c|c|c|c|c|c|c|c|c|c|c|c|c|c|c|}
\hline & & & & & $O C$ & & & Station & $O D$ & & & Station & 10 & & \\
\hline $\begin{array}{l}\text { Bin } \\
\text { No. }\end{array}$ & $\begin{array}{r}D_{L} \\
(1-\mathrm{m}) \\
\end{array}$ & $\begin{array}{c}D_{U} \\
(U m)\end{array}$ & $\begin{array}{c}D_{M} \\
(\mu m)\end{array}$ & Number ${ }^{1}$ & $\begin{array}{l}\text { Mass }^{1} \\
(\mu g)^{2}\end{array}$ & Number ${ }^{2}$ & $\begin{array}{l}\text { Mass }^{2} \\
(\mu g)\end{array}$ & Number 1 & $\begin{array}{l}\text { Mass }^{1} \\
(\mu g)^{2}\end{array}$ & Number ${ }^{2}$ & $\begin{array}{l}\text { Mass }^{2} \\
(\mu g) \\
\end{array}$ & Number 1 & $\begin{array}{l}\text { Mass: } \\
(i g)\end{array}$ & Number 2 & $\begin{array}{l}\text { Mass } \\
\text { (He }{ }^{2}\end{array}$ \\
\hline $\begin{array}{l}1 \\
2 \\
3 \\
4 \\
5\end{array}$ & $\begin{array}{l}112 \\
142 \\
178 \\
224 \\
282\end{array}$ & $\begin{array}{l}142 \\
178 \\
224 \\
282 \\
356\end{array}$ & $\begin{array}{l}126 \\
159 \\
200 \\
252 \\
317\end{array}$ & $\begin{array}{r}12 \\
0 \\
57 \\
0\end{array}$ & $\begin{array}{r}21 \\
0 \\
570 \\
0\end{array}$ & $\begin{array}{r}12 \\
0 \\
57 \\
43\end{array}$ & $\begin{array}{r}30 \\
0 \\
570 \\
850\end{array}$ & $\begin{array}{r}32 \\
0 \\
184 \\
0\end{array}$ & $\begin{array}{r}57 \\
0 \\
1800 \\
0\end{array}$ & $\begin{array}{r}32 \\
0 \\
184 \\
134\end{array}$ & $\begin{array}{r}30 \\
0 \\
1800 \\
2650\end{array}$ & $\begin{array}{r}6 \\
0 \\
64 \\
0\end{array}$ & $\begin{array}{r}11 \\
0 \\
640 \\
0\end{array}$ & $\begin{array}{r}6 \\
0 \\
64 \\
45\end{array}$ & $\begin{array}{r}15 \\
0 \\
640 \\
970\end{array}$ \\
\hline $\begin{array}{r}6 \\
7 \\
8 \\
9 \\
10\end{array}$ & $\begin{array}{l}356 \\
448 \\
563 \\
709 \\
893\end{array}$ & $\begin{array}{r}448 \\
563 \\
709 \\
893 \\
1124\end{array}$ & $\begin{array}{r}399 \\
502 \\
632 \\
796 \\
1000\end{array}$ & $\begin{array}{l}43 \\
41 \\
28 \\
14 \\
14\end{array}$ & $\begin{array}{l}1200 \\
2850 \\
2300 \\
3500 \\
7100\end{array}$ & $\begin{array}{r}41 \\
18 \\
24 \\
5 \\
0\end{array}$ & $\begin{array}{r}1620 \\
1170 \\
3310 \\
1110 \\
0\end{array}$ & $\begin{array}{r}134 \\
113 \\
27 \\
9 \\
3\end{array}$ & $\begin{array}{l}3800 \\
7400 \\
3500 \\
2230 \\
1300\end{array}$ & $\begin{array}{r}113 \\
27 \\
12 \\
2\end{array}$ & $\begin{array}{r}4460 \\
1740 \\
1560 \\
630\end{array}$ & $\begin{array}{r}46 \\
38 \\
11 \\
6 \\
5\end{array}$ & $\begin{array}{l}1300 \\
2400 \\
1460 \\
1420 \\
2200\end{array}$ & $\begin{array}{l}38 \\
11 \\
11 \\
1 \\
1\end{array}$ & $\begin{array}{r}1500 \\
730 \\
1500 \\
310 \\
440\end{array}$ \\
\hline $\begin{array}{l}11 \\
12 \\
13 \\
14 \\
15\end{array}$ & $\begin{array}{l}1124 \\
1415 \\
1780 \\
2240 \\
2820\end{array}$ & $\begin{array}{l}1415 \\
1780 \\
2240 \\
2820 \\
3550\end{array}$ & $\begin{array}{l}1260 \\
1590 \\
2000 \\
2520 \\
3170\end{array}$ & $\begin{array}{l}0 \\
1\end{array}$ & $\begin{array}{r}0 \\
2500\end{array}$ & 1 & 890 & 2 & 1800 & & & $\begin{array}{l}2 \\
1\end{array}$ & $\begin{array}{l}2190 \\
2500\end{array}$ & 1 & 890 \\
\hline $\begin{array}{l}16 \\
17\end{array}$ & $\begin{array}{l}3550 \\
4470\end{array}$ & $\begin{array}{l}4470 \\
5630\end{array}$ & $\begin{array}{l}3990 \\
5020\end{array}$ & & & & & & & & & & & & \\
\hline & & & & 200 & 20000 & 200 & 9550 & 504 & 21900 & 504 & 12900 & 179 & 14100 & 179 & 6940 \\
\hline
\end{tabular}

${ }^{2}$ ESC calibration plus adjustment 
TABLE E1.2. (Continued)

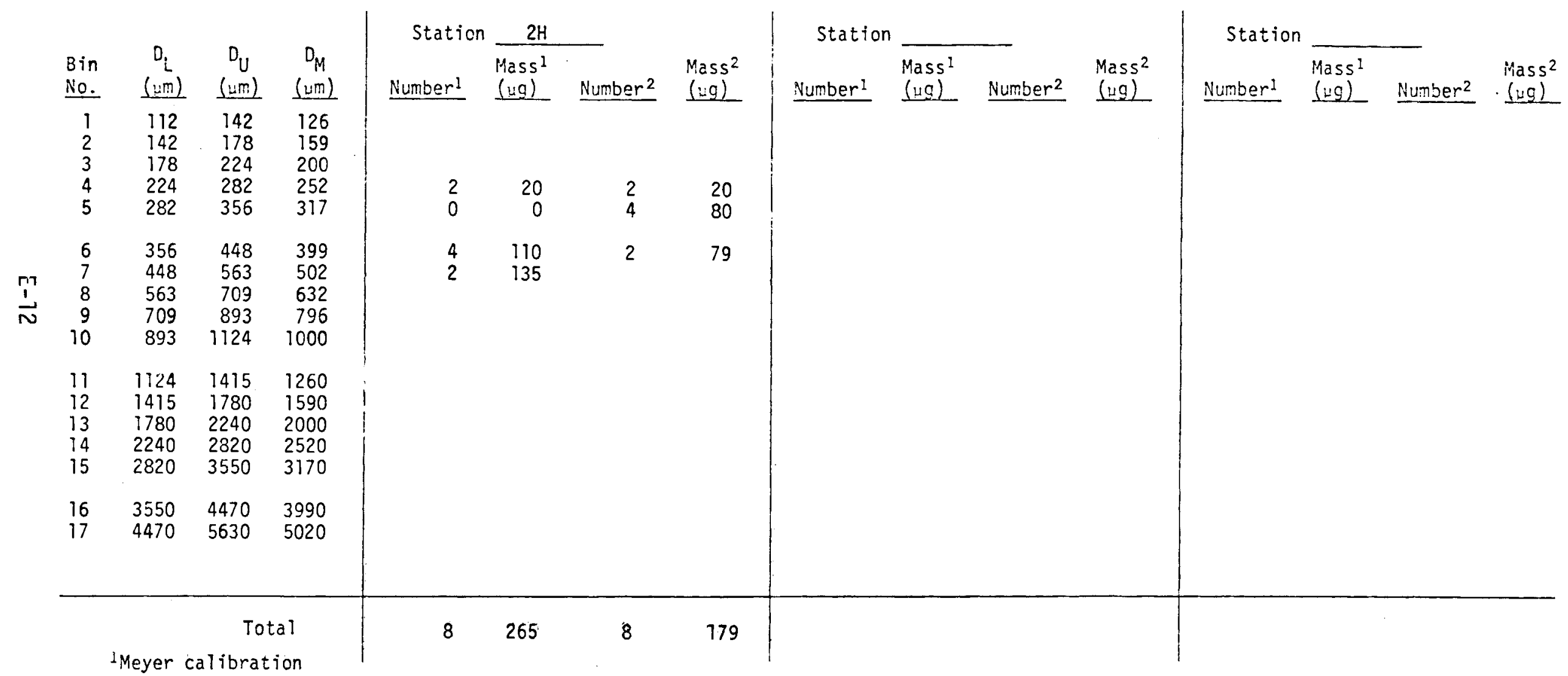

${ }^{2}$ ESC calibration plus adjustment 
TABLE EI.3. (Continued)

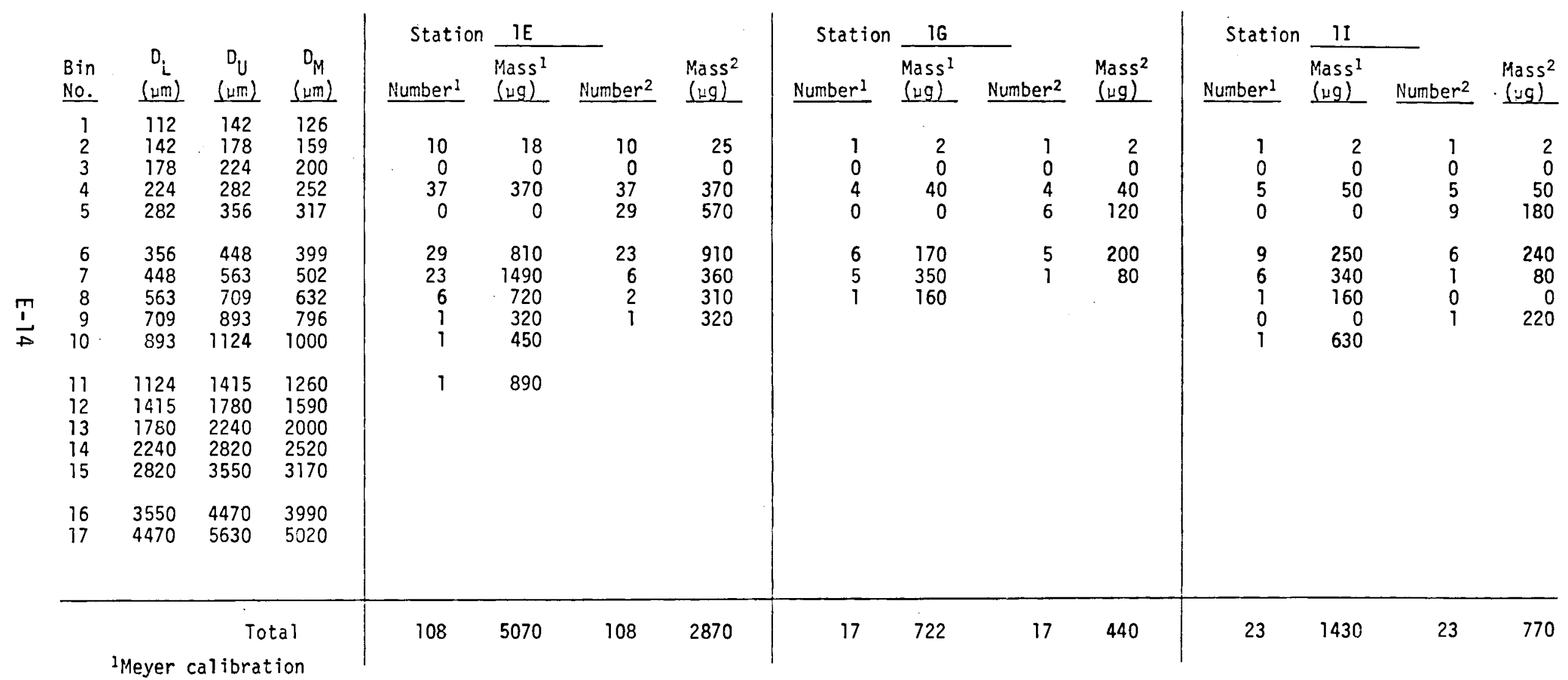

${ }^{2}$ ESC calibration plus adjustment 
TABLE E1.3. (Continued)

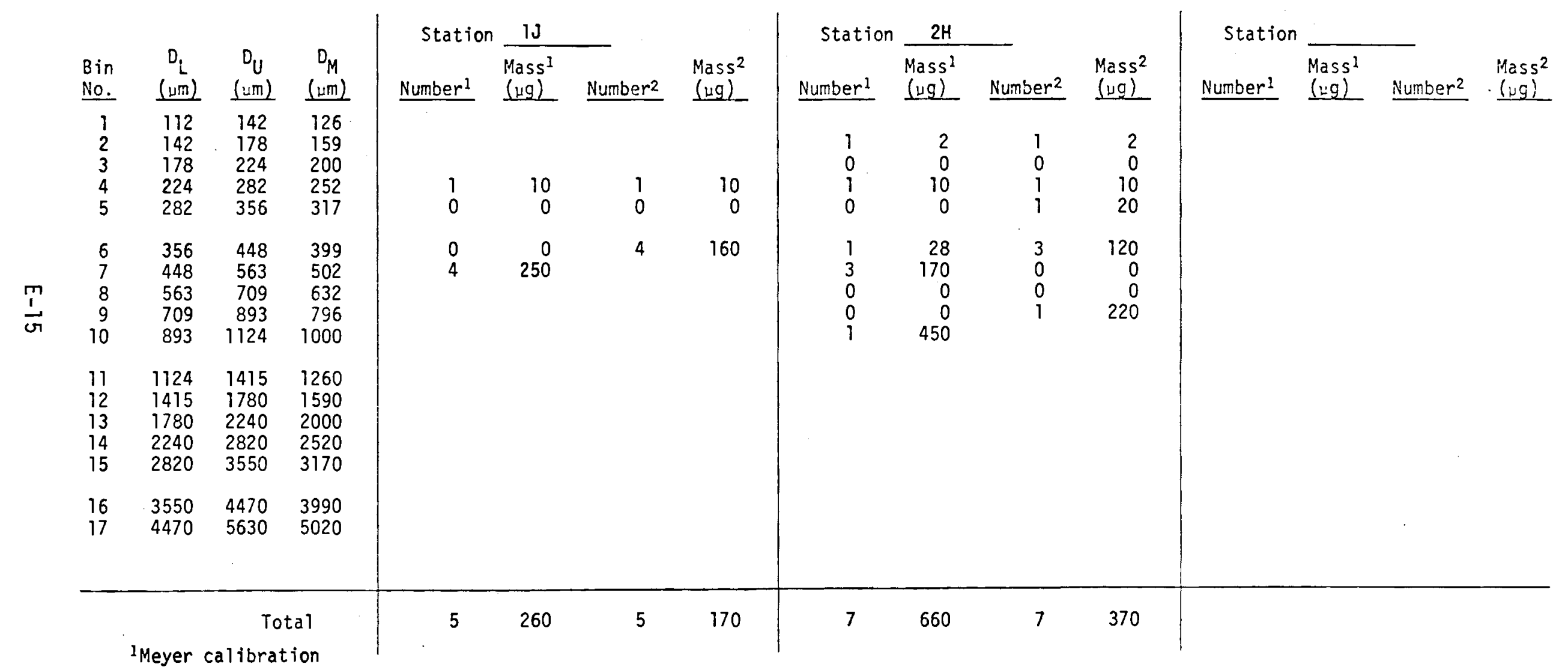

2 ESC calibration plus adjustment 
TABLE EI.4. Drift Droplet Deposition Spectra, Test Run 4, 21 June 1978

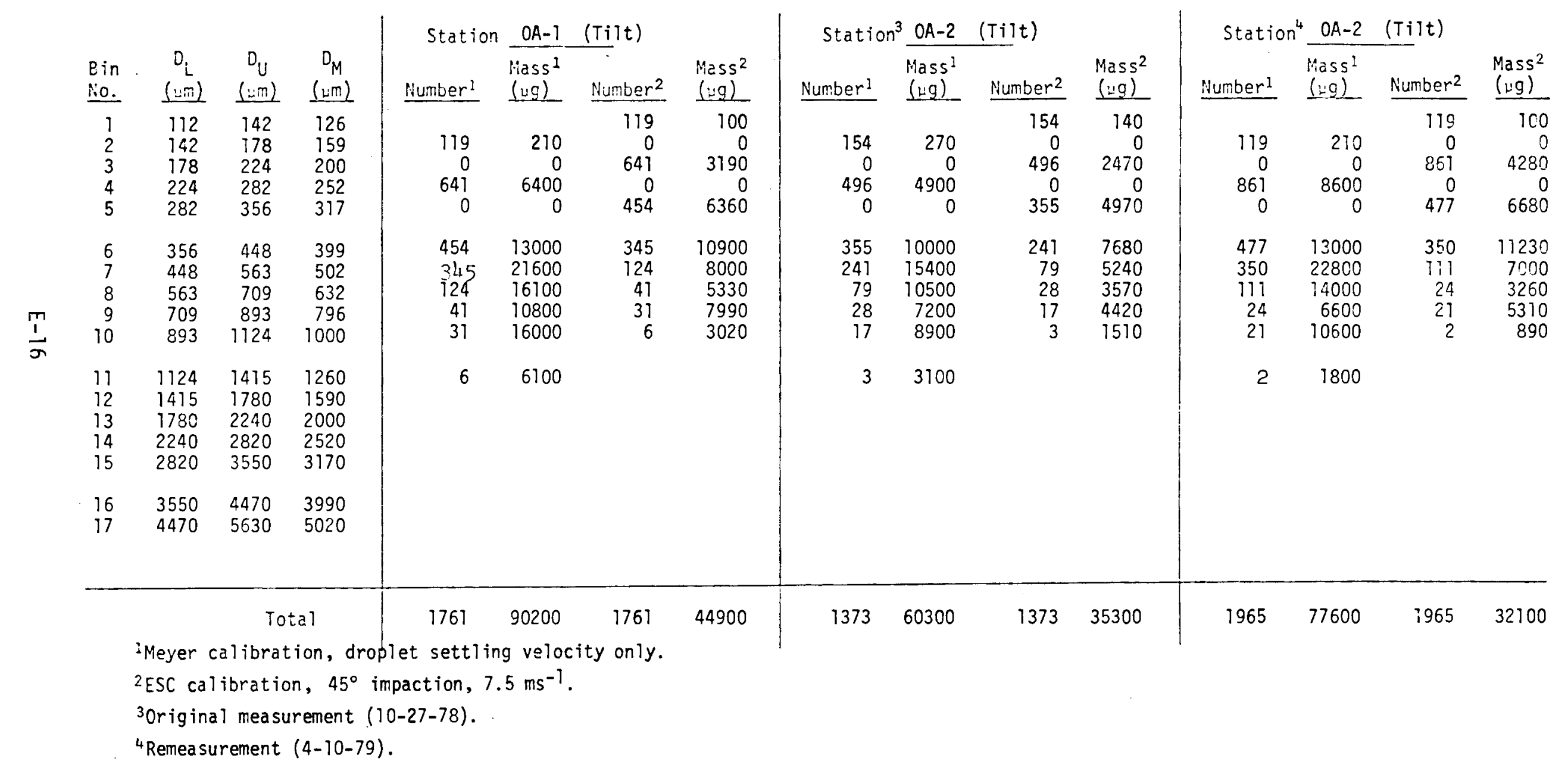


TABLE E1.4. (Continued)

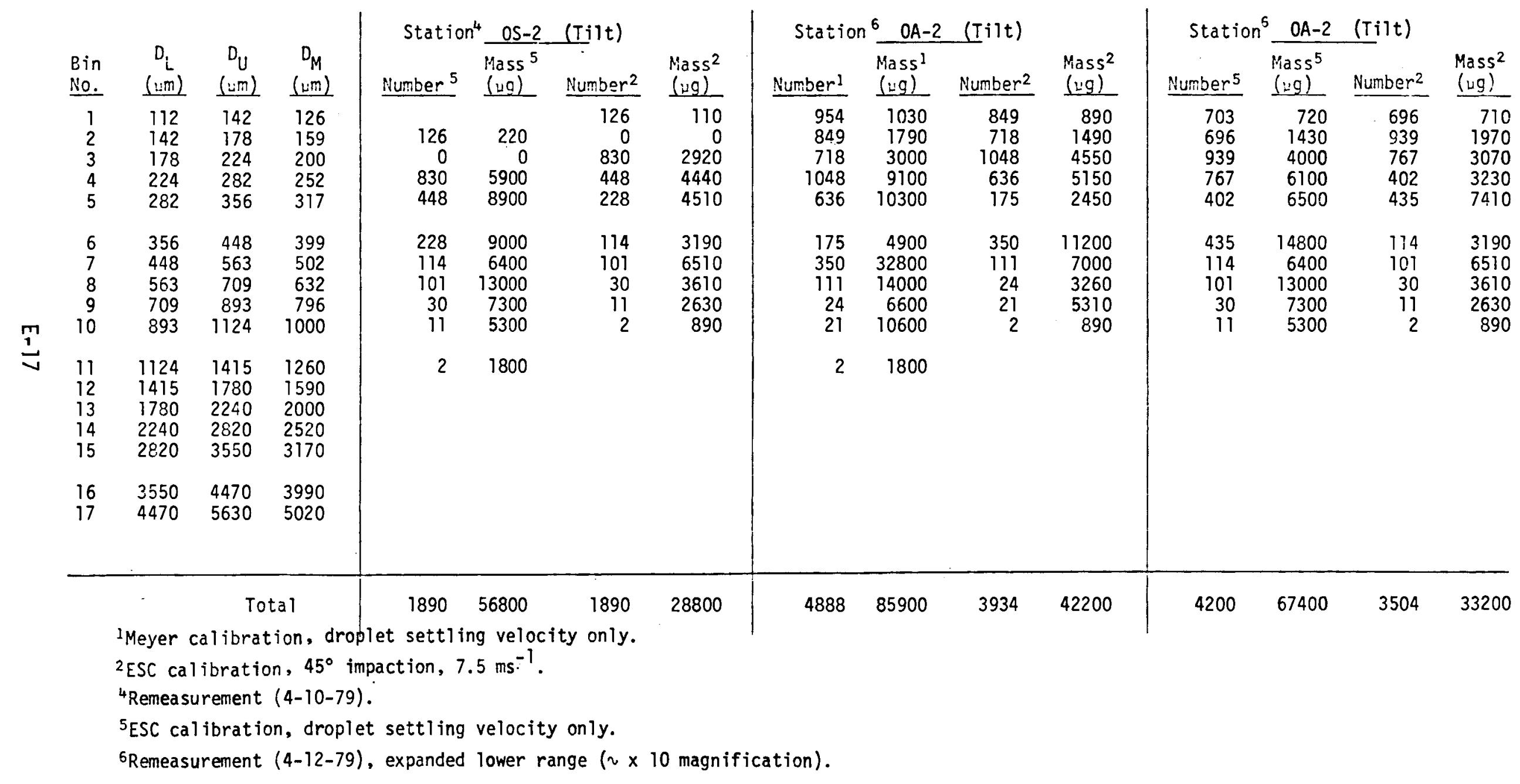


IABLE E1.4. (Cont inued)

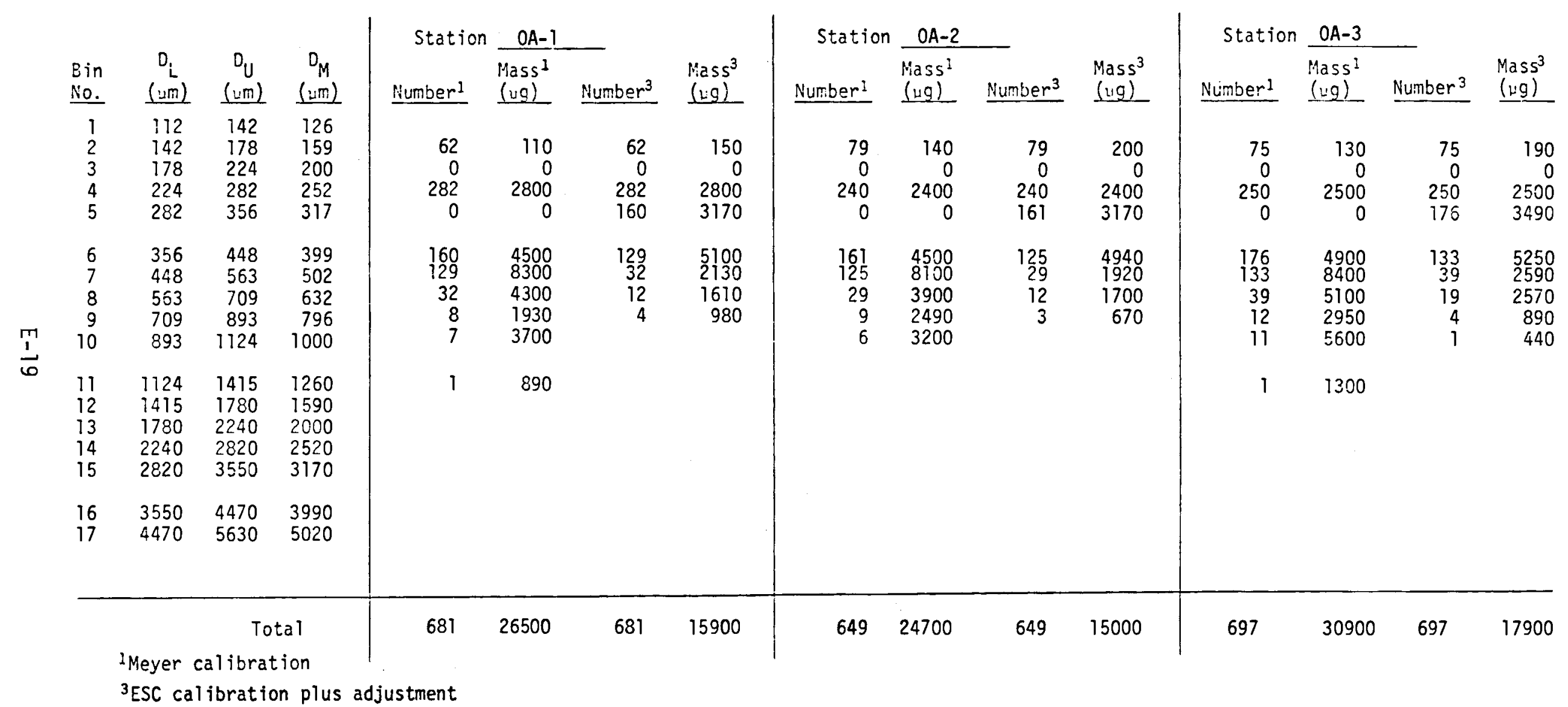

${ }^{3}$ ESC calibration plus adjustment 
TABLE EI.4. (Continued)

\begin{tabular}{|c|c|c|c|c|c|c|c|c|c|c|c|c|c|c|c|}
\hline & & & & Station & OA-4 & & & Station & $\mathrm{OBN}$ & & & Station & OBS & & \\
\hline $\begin{array}{l}\text { Bin } \\
\text { No. } \\
\end{array}$ & $\begin{array}{c}D_{i} \\
(\mathrm{um})\end{array}$ & $\begin{array}{r}D_{U} \\
(\mathrm{um}) \\
\end{array}$ & $\begin{array}{c}D_{\mathrm{M}} \\
\text { (um) }\end{array}$ & & $\begin{array}{l}\text { Mass }{ }^{2} \\
(\text { ug) }\end{array}$ & Number ${ }^{2}$ & $\begin{array}{l}\text { Mass }^{2} \\
\text { (ug) }\end{array}$ & Numberl & $\begin{array}{l}\text { Mass }{ }^{1} \\
(\mu \mathrm{g})\end{array}$ & Number ${ }^{2}$ & $\begin{array}{l}\text { Mass }^{2} \\
(\mu g)\end{array}$ & Number & $\begin{array}{l}\text { Mass } \\
\text { (tg) }\end{array}$ & Number ${ }^{2}$ & $\begin{array}{l}\text { Mass }^{2} \\
(\mu g)\end{array}$ \\
\hline $\begin{array}{l}1 \\
2 \\
3 \\
4 \\
5\end{array}$ & $\begin{array}{l}112 \\
142 \\
178 \\
224 \\
282\end{array}$ & $\begin{array}{l}142 \\
178 \\
224 \\
282 \\
356\end{array}$ & $\begin{array}{l}126 \\
159 \\
200 \\
252 \\
317\end{array}$ & $\begin{array}{r}11 \\
0 \\
49 \\
0\end{array}$ & $\begin{array}{r}20 \\
0 \\
490 \\
0\end{array}$ & $\begin{array}{r}11 \\
0 \\
49 \\
35\end{array}$ & $\begin{array}{r}30 \\
0 \\
490 \\
690\end{array}$ & $\begin{array}{r}69 \\
0 \\
238 \\
0\end{array}$ & $\begin{array}{r}120 \\
0 \\
2400 \\
0\end{array}$ & $\begin{array}{r}69 \\
0 \\
238 \\
177\end{array}$ & $\begin{array}{r}170 \\
0 \\
2400 \\
3500\end{array}$ & $\begin{array}{r}31 \\
0\end{array}$ & $\begin{array}{r}31 \\
0\end{array}$ & $\begin{array}{l}31 \\
33\end{array}$ & $\begin{array}{l}310 \\
650\end{array}$ \\
\hline $\begin{array}{r}6 \\
7 \\
8 \\
9 \\
10\end{array}$ & $\begin{array}{l}356 \\
448 \\
563 \\
709 \\
893\end{array}$ & $\begin{array}{r}448 \\
563 \\
709 \\
893 \\
1124\end{array}$ & $\begin{array}{r}399 \\
502 \\
632 \\
796 \\
1000\end{array}$ & $\begin{array}{r}35 \\
31 \\
5 \\
5 \\
2\end{array}$ & $\begin{array}{r}980 \\
1910 \\
560 \\
1100 \\
1080\end{array}$ & $\begin{array}{r}31 \\
10 \\
1 \\
1\end{array}$ & $\begin{array}{r}1220 \\
670 \\
160 \\
310\end{array}$ & $\begin{array}{r}177 \\
146 \\
53 \\
27 \\
15\end{array}$ & $\begin{array}{l}5000 \\
9600 \\
7100 \\
7100 \\
8000\end{array}$ & $\begin{array}{r}146 \\
53 \\
35 \\
11 \\
4\end{array}$ & $\begin{array}{r}5770 \\
3560 \\
4800 \\
2810 \\
640\end{array}$ & $\begin{array}{r}33 \\
27 \\
12 \\
9 \\
11\end{array}$ & $\begin{array}{r}930 \\
1740 \\
1740 \\
2490 \\
5800\end{array}$ & $\begin{array}{r}27 \\
12 \\
15 \\
9 \\
1\end{array}$ & $\begin{array}{r}1070 \\
880 \\
2170 \\
2370 \\
440\end{array}$ \\
\hline $\begin{array}{l}11 \\
12 \\
13 \\
14 \\
15\end{array}$ & $\begin{array}{l}1724 \\
1415 \\
1780 \\
2240 \\
2820\end{array}$ & $\begin{array}{l}1415 \\
1780 \\
2240 \\
2820 \\
3550\end{array}$ & $\begin{array}{l}1260 \\
1590 \\
2000 \\
2520 \\
3170\end{array}$ & 1 & 1300 & & & $\begin{array}{l}7 \\
3\end{array}$ & $\begin{array}{l}7400 \\
6800\end{array}$ & 2 & 1770 & $\begin{array}{l}5 \\
1\end{array}$ & $\begin{array}{l}4900 \\
2500\end{array}$ & 1 & 890 \\
\hline $\begin{array}{l}16 \\
17\end{array}$ & $\begin{array}{l}3550 \\
4470\end{array}$ & $\begin{array}{l}4470 \\
5630\end{array}$ & $\begin{array}{l}3990 \\
5020\end{array}$ & & & & & & & & & & & & \\
\hline & & & & 139 & 7740 & 139 & 3570 & 735 & 53500 & 735 & 25400 & 129 & 20400 & 129 & 8780 \\
\hline
\end{tabular}

2 ESC calibration plus adjustment 
TABLE E1.4. (Continued)

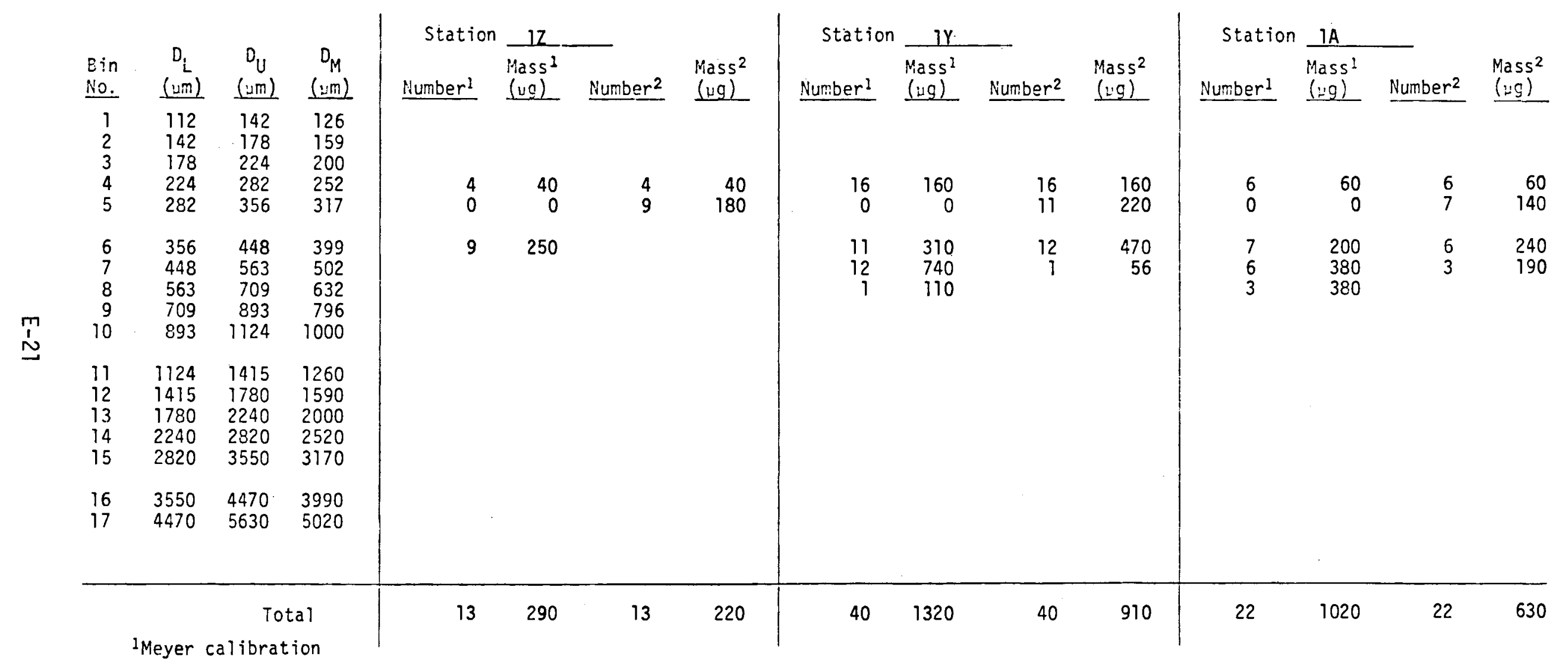

${ }^{2}$ ESC calibration plus adjustment 
TABLE E1.4. (Continued)

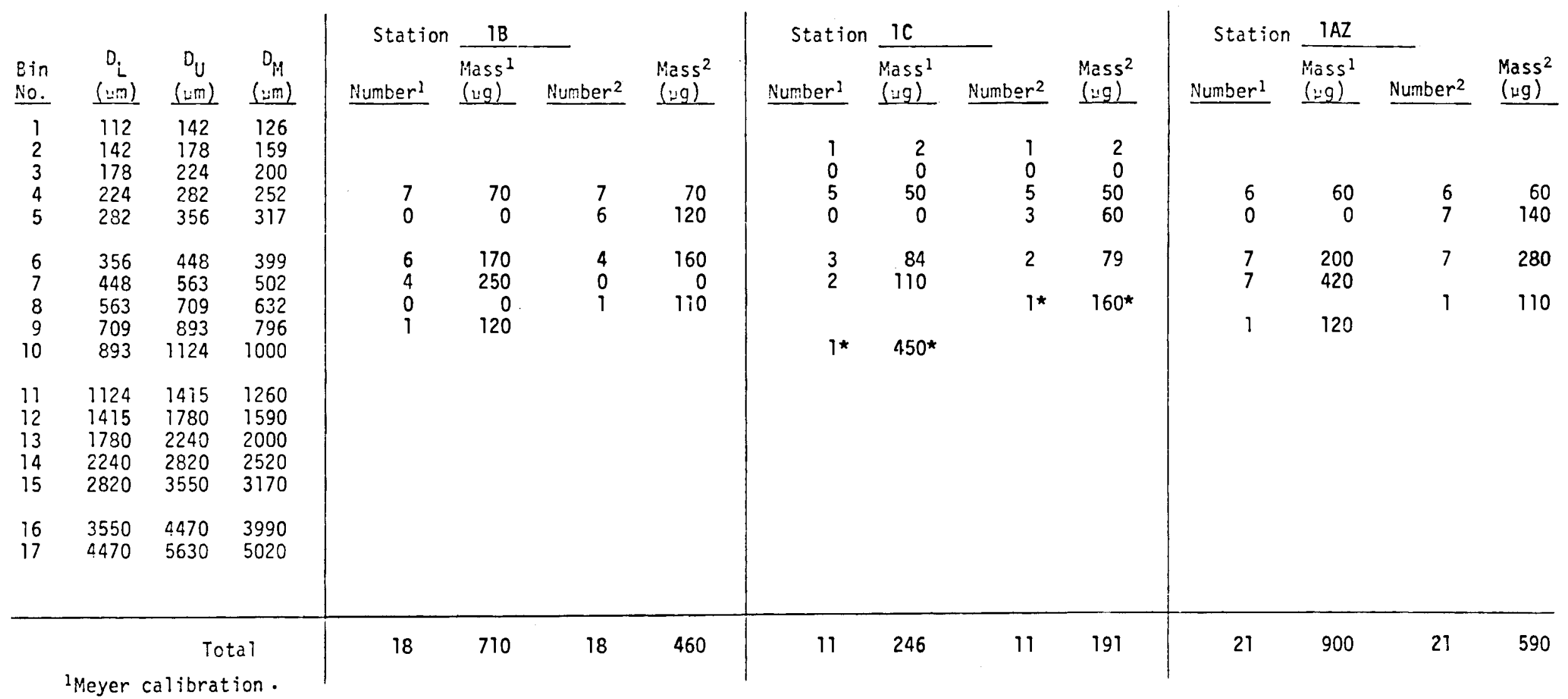

2ESC calibration plus adjustment.

* Not included in total. 


\section{TABLE E1.4. (Continued)}

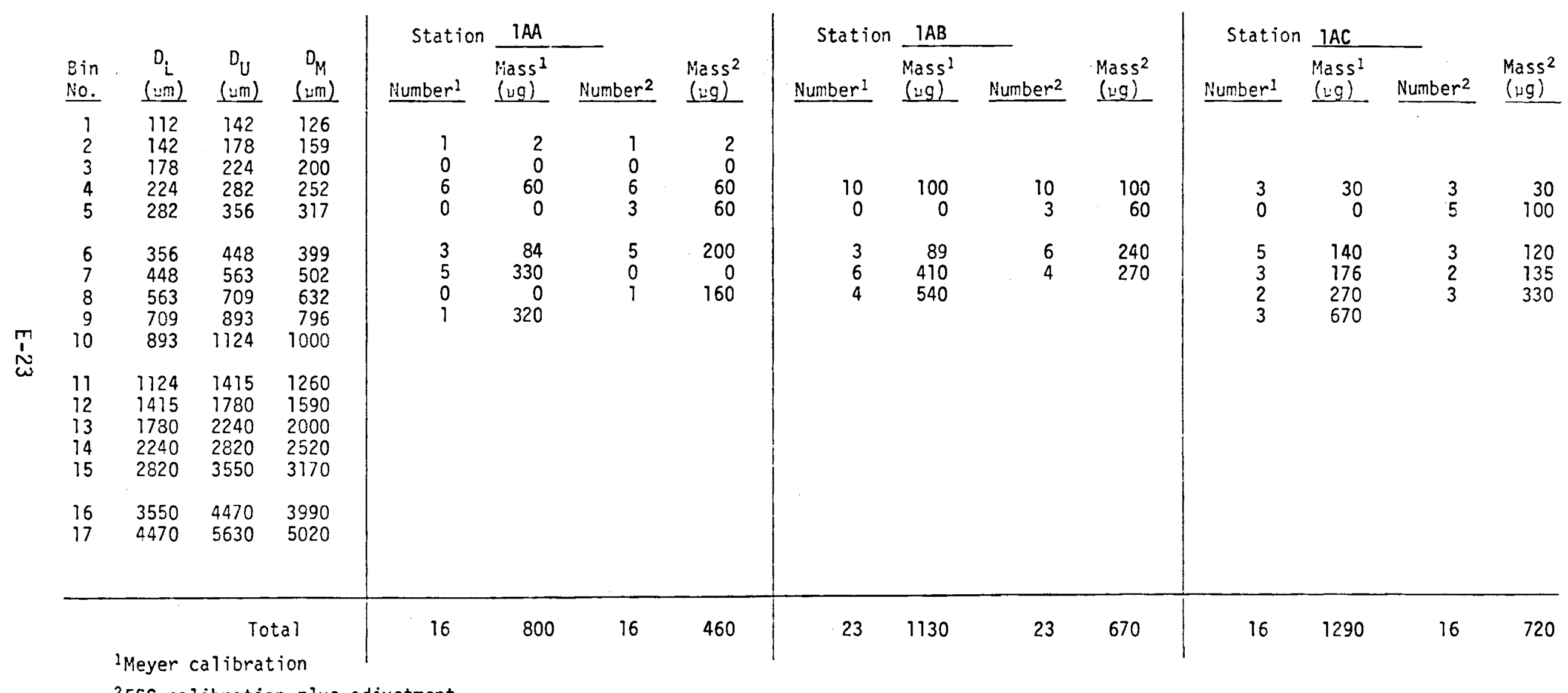

${ }^{2}$ ESC calibration plus adjustment 
IABLE E].4. (Continued)

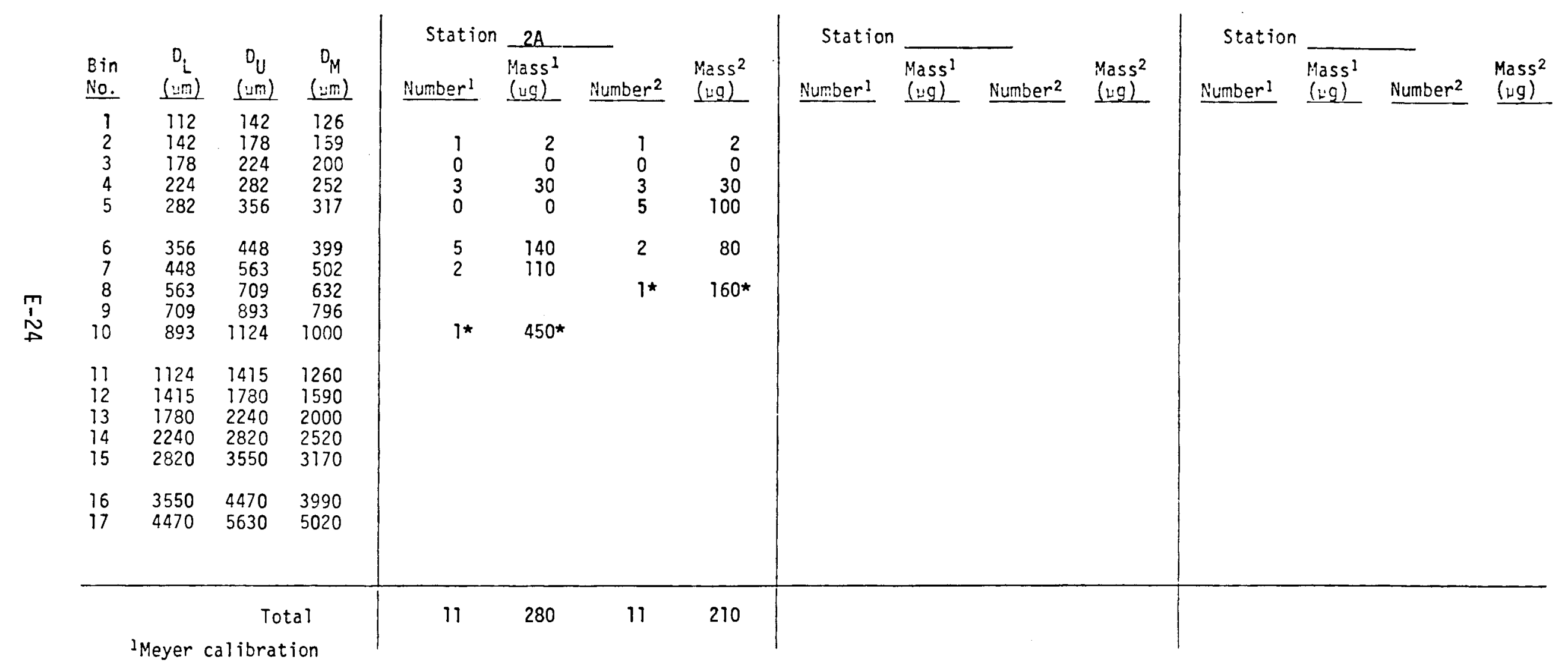

${ }^{2}$ ESC calibration plus adjustment

* Not included in total. 
TABLE E1.5. Drift Droplet Deposition Spectra, Test Run 5, 18 June 1978

\begin{tabular}{|c|c|c|c|c|c|c|c|c|c|c|c|c|c|c|c|}
\hline & & & & Station & 12 & & & Station & $1 Y-1$ & & & Station & $18-2$ & & \\
\hline $\begin{array}{l}\text { Bin } \\
\text { No. }\end{array}$ & $\begin{array}{c}D_{L} \\
(\mu \mathrm{m})\end{array}$ & $\begin{array}{c}D_{U} \\
(u m)\end{array}$ & $\begin{array}{c}D_{M} \\
(\mu \mathrm{m}) \\
\end{array}$ & & $\begin{array}{l}\text { Mass }{ }^{1} \\
\text { (ug) }\end{array}$ & Number 2 & $\begin{array}{l}\text { Mass }^{2} \\
(\because g)\end{array}$ & Number 1 & $\begin{array}{l}\text { Mass }^{1} \\
\text { (ug) }\end{array}$ & Number ${ }^{2}$ & $\begin{array}{c}\operatorname{Mass}^{2} \\
(\mu g)\end{array}$ & Number 1 & $\begin{array}{l}\text { Mass }^{1} \\
(\mu g)\end{array}$ & Number ${ }^{2}$ & $\begin{array}{l}M_{2 s s^{2}} \\
(u g)\end{array}$ \\
\hline $\begin{array}{l}1 \\
2 \\
3 \\
4 \\
5\end{array}$ & $\begin{array}{l}112 \\
142 \\
178 \\
224 \\
282\end{array}$ & $\begin{array}{l}142 \\
178 \\
224 \\
282 \\
356\end{array}$ & $\begin{array}{l}126 \\
159 \\
200 \\
252 \\
317\end{array}$ & $\begin{array}{l}8 \\
0\end{array}$ & $\begin{array}{r}80 \\
0\end{array}$ & $\begin{array}{l}8 \\
0\end{array}$ & $\begin{array}{r}80 \\
0\end{array}$ & $\begin{array}{r}34 \\
0 \\
118 \\
0\end{array}$ & $\begin{array}{r}60 \\
0 \\
1200 \\
0\end{array}$ & $\begin{array}{r}34 \\
0 \\
118 \\
91\end{array}$ & $\begin{array}{r}85 \\
0 \\
1200 \\
1800\end{array}$ & $\begin{array}{r}5 \\
0 \\
23 \\
0\end{array}$ & $\begin{array}{r}9 \\
0 \\
230 \\
0\end{array}$ & $\begin{array}{r}5 \\
0 \\
23 \\
14\end{array}$ & $\begin{array}{r}12 \\
0 \\
230 \\
280\end{array}$ \\
\hline $\begin{array}{r}6 \\
7 \\
8 \\
9 \\
10\end{array}$ & $\begin{array}{l}356 \\
448 \\
563 \\
709 \\
893\end{array}$ & $\begin{array}{r}448 \\
563 \\
709 \\
893 \\
1124\end{array}$ & $\begin{array}{r}399 \\
502 \\
632 \\
796 \\
1000\end{array}$ & $\begin{array}{l}0 \\
1\end{array}$ & $\begin{array}{r}0 \\
79\end{array}$ & 1 & 40 & $\begin{array}{l}91 \\
68 \\
28 \\
12 \\
11\end{array}$ & $\begin{array}{l}2600 \\
4400 \\
3800 \\
3200 \\
5800\end{array}$ & $\begin{array}{r}68 \\
28 \\
18 \\
6 \\
3\end{array}$ & $\begin{array}{l}2690 \\
1860 \\
1730 \\
1420 \\
1330\end{array}$ & $\begin{array}{r}14 \\
14 \\
3\end{array}$ & $\begin{array}{l}390 \\
860 \\
430\end{array}$ & $\begin{array}{c}14 \\
3 \\
1 *\end{array}$ & $\begin{array}{l}550 \\
2 i 0 \\
\\
440^{*}\end{array}$ \\
\hline $\begin{array}{l}11 \\
12 \\
13 \\
14 \\
15\end{array}$ & $\begin{array}{l}1124 \\
1475 \\
1780 \\
2240 \\
2820\end{array}$ & $\begin{array}{l}1415 \\
1780 \\
2240 \\
2820 \\
3550\end{array}$ & $\begin{array}{l}1260 \\
1590 \\
2000 \\
2520 \\
3170\end{array}$ & & & & & $\begin{array}{l}4 \\
0 \\
1\end{array}$ & $\begin{array}{r}4690 \\
0 \\
3500\end{array}$ & 1 & 1250 & 1* & $1300 *$ & & \\
\hline $\begin{array}{l}16 \\
17\end{array}$ & $\begin{array}{l}3550 \\
4470\end{array}$ & $\begin{array}{l}4470 \\
5630\end{array}$ & $\begin{array}{l}3990 \\
5020\end{array}$ & & & & & & & & & & & & \\
\hline & & & & 9 & 159 & 9 & 120 & 367 & 29200 & 367 & 13400 & 59 & 1920 & 59 & 1280 \\
\hline
\end{tabular}

${ }^{2}$ ESC calibration plus adjustment

${ }^{*}$ Not included in total 
TABLE El.5. (Continued)

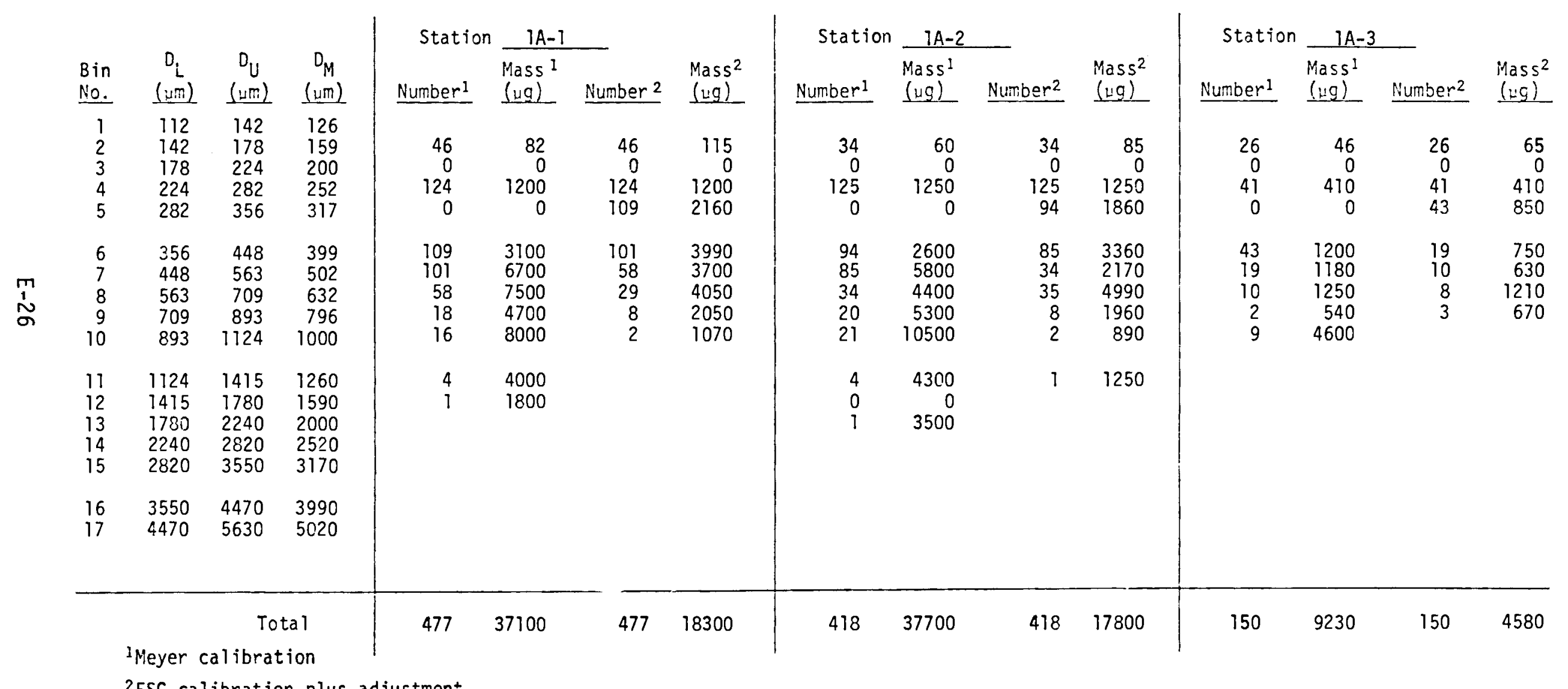

2 ESC calibration plus adjustment 
TABLE E].5. (Continued)

\begin{tabular}{|c|c|c|c|c|c|c|c|c|c|c|c|c|c|c|c|}
\hline \multirow[b]{2}{*}{$\begin{array}{l}\text { Bin } \\
\text { No. }\end{array}$} & \multirow[b]{2}{*}{$\begin{array}{c}D_{L} \\
(\mu m)\end{array}$} & \multirow[b]{2}{*}{$\begin{array}{c}D_{u} \\
\dot{(u m)}\end{array}$} & \multirow[b]{2}{*}{$\begin{array}{c}D_{M} \\
(\mu \mathrm{m}) \\
\end{array}$} & \multirow{2}{*}{$\begin{array}{r}\text { Station } \\
\text { Number } \\
\end{array}$} & \multicolumn{2}{|l|}{$1 B-1$} & \multirow[b]{2}{*}{$\begin{array}{c}\text { Mass }^{2} \\
(\mu g)\end{array}$} & \multirow{2}{*}{$\begin{array}{l}\text { Station } \\
\text { Number } \\
\end{array}$} & \multicolumn{2}{|l|}{$1 \mathrm{~B}-2$} & \multirow[b]{2}{*}{$\begin{array}{l}\text { Mass }^{2} \\
(\mu g)\end{array}$} & \multirow{2}{*}{$\begin{array}{l}\text { Station } \\
\text { Number }\end{array}$} & \multicolumn{2}{|l|}{$18-3$} & \multirow[b]{2}{*}{$\begin{array}{l}\text { Mass }^{2} \\
(\mu \mathrm{g})\end{array}$} \\
\hline & & & & & $\begin{array}{l}\text { Mass }{ }^{1} \\
(\mu g)\end{array}$ & Number 2 & & & $\begin{array}{l}\text { Mass }^{1} \\
(\mu \mathrm{g})\end{array}$ & Number ${ }^{2}$ & & & $\begin{array}{l}\text { Mass } 1 \\
(\mu g)\end{array}$ & Number ${ }^{2}$ & \\
\hline $\begin{array}{l}1 \\
2 \\
3 \\
4 \\
5\end{array}$ & $\begin{array}{l}112 \\
142 \\
178 \\
224 \\
282\end{array}$ & $\begin{array}{l}142 \\
178 \\
224 \\
282 \\
356\end{array}$ & $\begin{array}{l}126 \\
159 \\
200 \\
252 \\
317\end{array}$ & $\begin{array}{r}167 \\
0 \\
165 \\
0\end{array}$ & $\begin{array}{r}380 \\
0 \\
1650 \\
0\end{array}$ & $\begin{array}{r}167 \\
0 \\
165 \\
142\end{array}$ & $\begin{array}{r}420 \\
0 \\
1650 \\
2810\end{array}$ & $\begin{array}{r}112 \\
0 \\
128 \\
0\end{array}$ & $\begin{array}{r}200 \\
0 \\
1280 \\
0\end{array}$ & $\begin{array}{r}112 \\
0 \\
128 \\
91\end{array}$ & $\begin{array}{r}280 \\
0 \\
1280 \\
1800\end{array}$ & $\begin{array}{r}104 \\
0 \\
83 \\
0\end{array}$ & $\begin{array}{r}180 \\
0 \\
830 \\
0\end{array}$ & $\begin{array}{r}104 \\
0 \\
83 \\
59\end{array}$ & $\begin{array}{r}260 \\
0 \\
830 \\
1170\end{array}$ \\
\hline $\begin{array}{r}6 \\
7 \\
8 \\
9 \\
10\end{array}$ & $\begin{array}{l}356 \\
448 \\
563 \\
709 \\
893\end{array}$ & $\begin{array}{r}448 \\
563 \\
709 \\
893 \\
1124\end{array}$ & $\begin{array}{r}399 \\
502 \\
632 \\
796 \\
1000\end{array}$ & $\begin{array}{r}142 \\
119 \\
56 \\
31 \\
26\end{array}$ & $\begin{array}{r}4000 \\
7700 \\
7400 \\
8060 \\
13000\end{array}$ & $\begin{array}{r}119 \\
56 \\
49 \\
11 \\
5\end{array}$ & $\begin{array}{l}4580 \\
3700 \\
6820 \\
2720 \\
2580\end{array}$ & $\begin{array}{r}91 \\
79 \\
31 \\
20 \\
9\end{array}$ & $\begin{array}{l}2600 \\
5300 \\
4000 \\
5000 \\
4400\end{array}$ & $\begin{array}{r}79 \\
31 \\
27 \\
4 \\
4\end{array}$ & $\begin{array}{l}3120 \\
2010 \\
3600 \\
1070 \\
2140\end{array}$ & $\begin{array}{r}59 \\
49 \\
31 \\
9 \\
11\end{array}$ & $\begin{array}{l}1700 \\
3300 \\
4100 \\
2120 \\
5600\end{array}$ & $\begin{array}{r}49 \\
31 \\
76 \\
5 \\
4\end{array}$ & $\begin{array}{l}1940 \\
2050 \\
1070 \\
1200 \\
1960\end{array}$ \\
\hline $\begin{array}{l}11 \\
12 \\
13 \\
14 \\
15\end{array}$ & $\begin{array}{l}1124 \\
1415 \\
1780 \\
2240 \\
2820\end{array}$ & $\begin{array}{l}1415 \\
1780 \\
2240 \\
2820 \\
3550\end{array}$ & $\begin{array}{l}1260 \\
1590 \\
2000 \\
2520 \\
3170\end{array}$ & $\begin{array}{l}6 \\
2 \\
1\end{array}$ & $\begin{array}{l}6500 \\
3500 \\
3500\end{array}$ & 1 & 1250 & $\begin{array}{l}4 \\
3\end{array}$ & $\begin{array}{l}4300 \\
6000\end{array}$ & 1 & 890 & $\begin{array}{l}4 \\
1 \\
2\end{array}$ & $\begin{array}{l}4690 \\
1800 \\
7100\end{array}$ & 2 & 2500 \\
\hline $\begin{array}{l}16 \\
17\end{array}$ & $\begin{array}{l}3550 \\
4470\end{array}$ & $\begin{array}{l}4470 \\
5630\end{array}$ & $\begin{array}{l}3990 \\
5020\end{array}$ & & & & & & & & & & & & \\
\hline & & To & & 715 & 55600 & 715 & 26500 & 477 & 33100 & 477 & 17200 & 353 & 34300 & 353 & 13000 \\
\hline
\end{tabular}

2ESC calibration pius adjustment 
TABLE E7.5. (Continued)

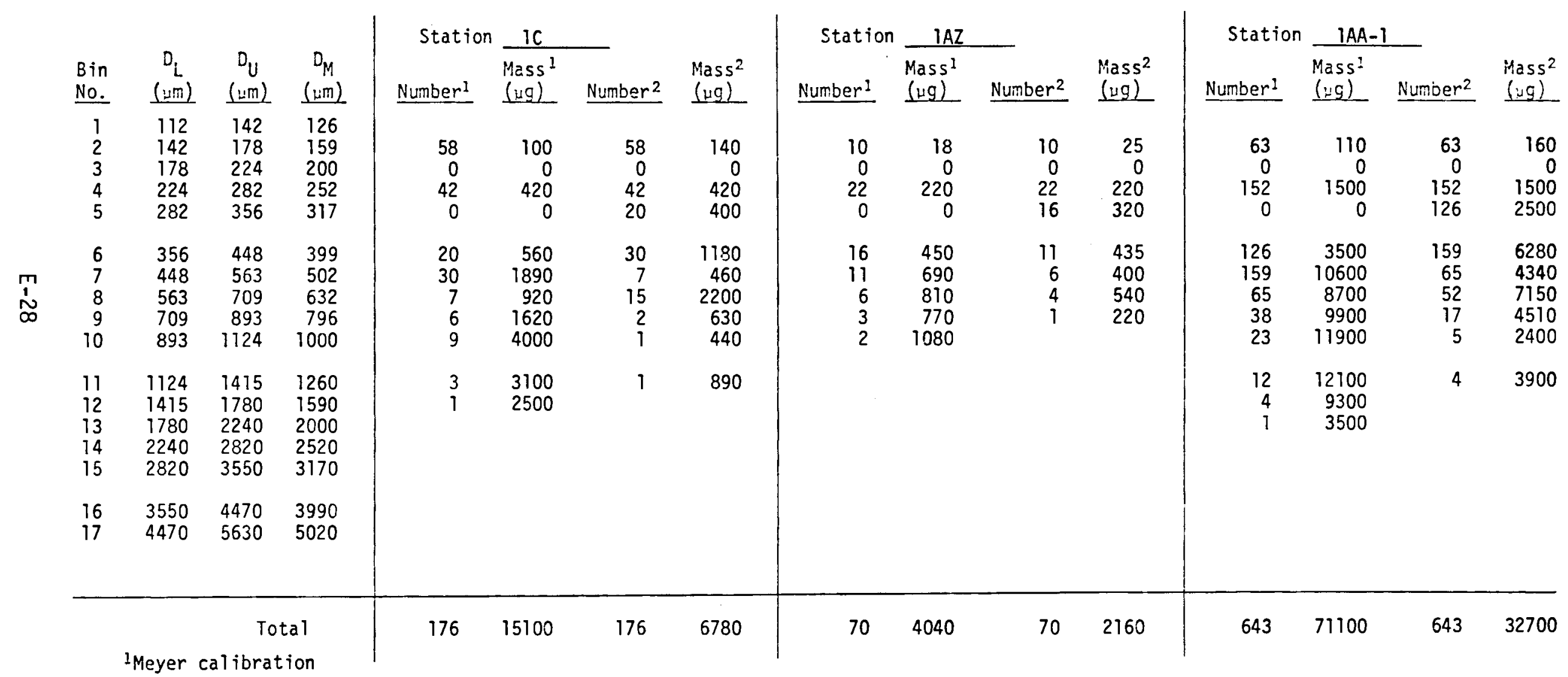

${ }^{2}$ ESC calibration plus adjustment 
TABLE E1.5. (Continued)

\begin{tabular}{|c|c|c|c|c|c|c|c|c|c|c|c|c|c|c|c|}
\hline & & & & Station & IAA- & & & Station & $1 \mathrm{AB}$ & & & Station & $2 A$ & & \\
\hline $\begin{array}{l}\text { Bin } \\
\text { No. } \\
\end{array}$ & $\begin{array}{c}D_{i} \\
(\mu m) \\
\end{array}$ & $\begin{array}{r}D_{U} \\
(\mu \mathrm{m}) \\
\end{array}$ & $\begin{array}{r}D_{M} \\
(\mathrm{um}) \\
\end{array}$ & Number 1 & $\begin{array}{l}\text { Mass }{ }^{1} \\
(\mu g)\end{array}$ & Number ${ }^{2}$ & $\begin{array}{l}\text { Mass }^{2} \\
(\mu \mathrm{g})\end{array}$ & Number ${ }^{2}$ & $\begin{array}{l}\text { Mass } \\
(\mu g)\end{array}$ & Number ${ }^{2}$ & $\begin{array}{l}\text { Mass }^{2} \\
(\mu \mathrm{g})\end{array}$ & Number ${ }^{1}$ & $\begin{array}{l}\text { Mass }^{1} \\
(\mu \mathrm{g})\end{array}$ & Number ${ }^{2}$ & $\begin{array}{l}\text { Mass }^{2} \\
\text { (ug) }\end{array}$ \\
\hline $\begin{array}{l}1 \\
2 \\
3 \\
4 \\
5\end{array}$ & $\begin{array}{l}112 \\
142 \\
178 \\
224 \\
282\end{array}$ & $\begin{array}{l}142 \\
178 \\
224 \\
282 \\
356\end{array}$ & $\begin{array}{l}126 \\
159 \\
200 \\
252 \\
317\end{array}$ & $\begin{array}{r}28 \\
0 \\
38 \\
0\end{array}$ & $\begin{array}{r}50 \\
0 \\
380 \\
0\end{array}$ & $\begin{array}{r}28 \\
0 \\
38 \\
36\end{array}$ & $\begin{array}{r}70 \\
0 \\
380 \\
710\end{array}$ & $\begin{array}{r}15 \\
0 \\
60 \\
0\end{array}$ & $\begin{array}{r}27 \\
0 \\
600 \\
0\end{array}$ & $\begin{array}{r}15 \\
0 \\
60 \\
49\end{array}$ & $\begin{array}{r}40 \\
0 \\
600 \\
970\end{array}$ & $\begin{array}{r}11 \\
0 \\
27 \\
0\end{array}$ & $\begin{array}{r}20 \\
0 \\
270 \\
0\end{array}$ & $\begin{array}{r}11 \\
0 \\
27 \\
27\end{array}$ & $\begin{array}{r}27 \\
0 \\
270 \\
535\end{array}$ \\
\hline $\begin{array}{r}6 \\
7 \\
8 \\
9 \\
10\end{array}$ & $\begin{array}{l}356 \\
448 \\
563 \\
709 \\
893\end{array}$ & $\begin{array}{r}448 \\
563 \\
709 \\
893 \\
1124\end{array}$ & $\begin{array}{r}399 \\
502 \\
632 \\
796 \\
1000\end{array}$ & $\begin{array}{r}36 \\
28 \\
19 \\
4 \\
7\end{array}$ & $\begin{array}{l}1000 \\
1790 \\
2500 \\
1080 \\
3500\end{array}$ & $\begin{array}{r}28 \\
19 \\
9 \\
2\end{array}$ & $\begin{array}{r}1110 \\
1240 \\
1320 \\
440\end{array}$ & $\begin{array}{l}49 \\
37 \\
15 \\
12 \\
15\end{array}$ & $\begin{array}{l}1400 \\
2400 \\
2080 \\
3300 \\
8000\end{array}$ & $\begin{array}{r}37 \\
15 \\
20 \\
8 \\
4\end{array}$ & $\begin{array}{l}1460 \\
1020 \\
2910 \\
1870 \\
2320\end{array}$ & $\begin{array}{r}27 \\
23 \\
8 \\
1 \\
0\end{array}$ & $\begin{array}{r}760 \\
1540 \\
1130 \\
320 \\
0\end{array}$ & $\begin{array}{r}23 \\
8 \\
1 \\
1\end{array}$ & $\begin{array}{l}910 \\
560 \\
160 \\
320\end{array}$ \\
\hline $\begin{array}{l}11 \\
12 \\
13 \\
14 \\
15\end{array}$ & $\begin{array}{l}1124 \\
1415 \\
1780 \\
2240 \\
2820\end{array}$ & $\begin{array}{l}1415 \\
1780 \\
2240 \\
2820 \\
3550\end{array}$ & $\begin{array}{l}1260 \\
1590 \\
2000 \\
2520 \\
3170\end{array}$ & & & & & $\begin{array}{l}2 \\
4\end{array}$ & $\begin{array}{l}2190 \\
7800\end{array}$ & 1 & 890 & 1 & 890 & & \\
\hline $\begin{array}{l}16 \\
17\end{array}$ & $\begin{array}{l}3550 \\
4470\end{array}$ & $\begin{array}{l}4470 \\
5630\end{array}$ & $\begin{array}{l}3990 \\
5020\end{array}$ & & & & & & & & & & & & \\
\hline & & & & 160 & 10300 & 160 & 5270 & 209 & 27800 & 209 & 12100 & 98 & 4930 & 98 & 2780 \\
\hline
\end{tabular}

${ }^{2}$ ESC calibration plus adjustment 
TABLE E1.6. Drift Droplet Deposition Spectra, Test Run 6, 22 June 1978

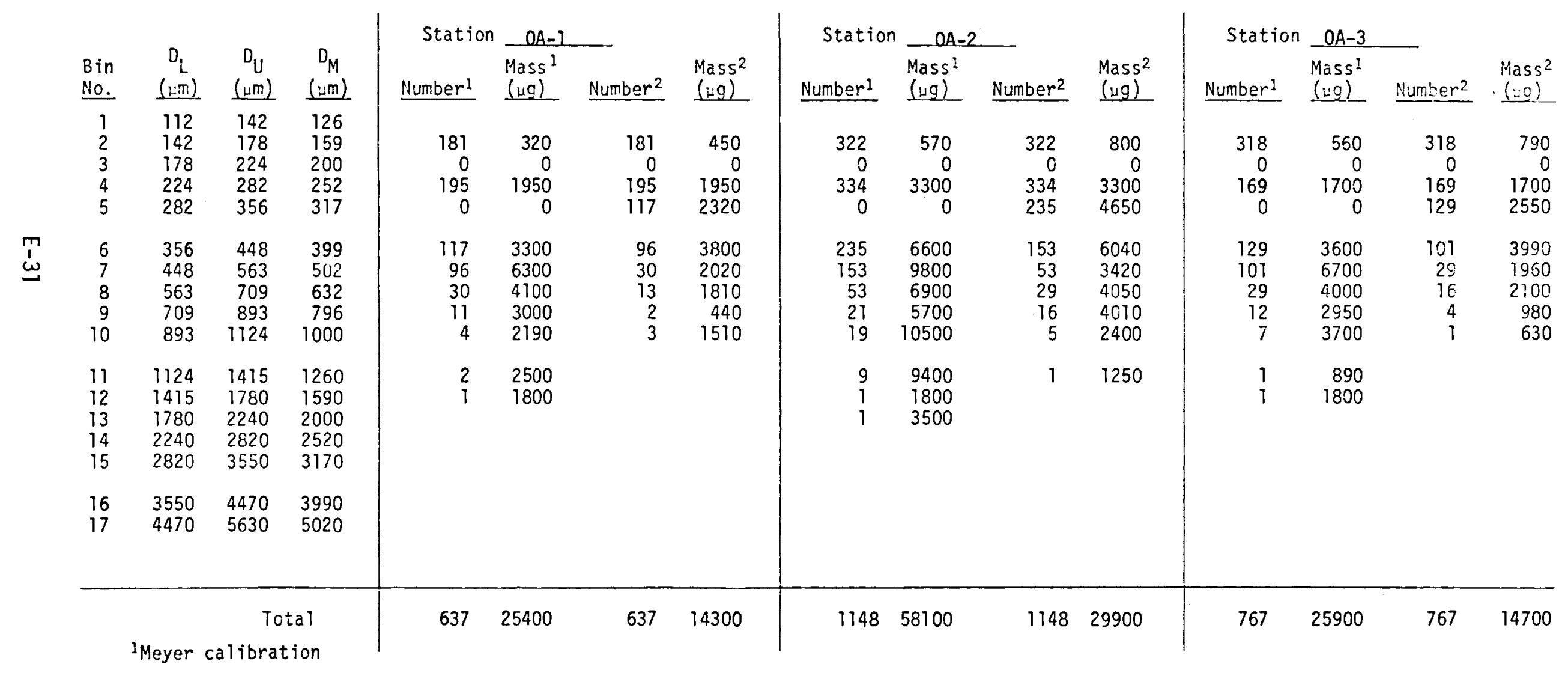

${ }^{2}$ ESC calibration plus adjustment 
TABLE ET.6. (Continued)

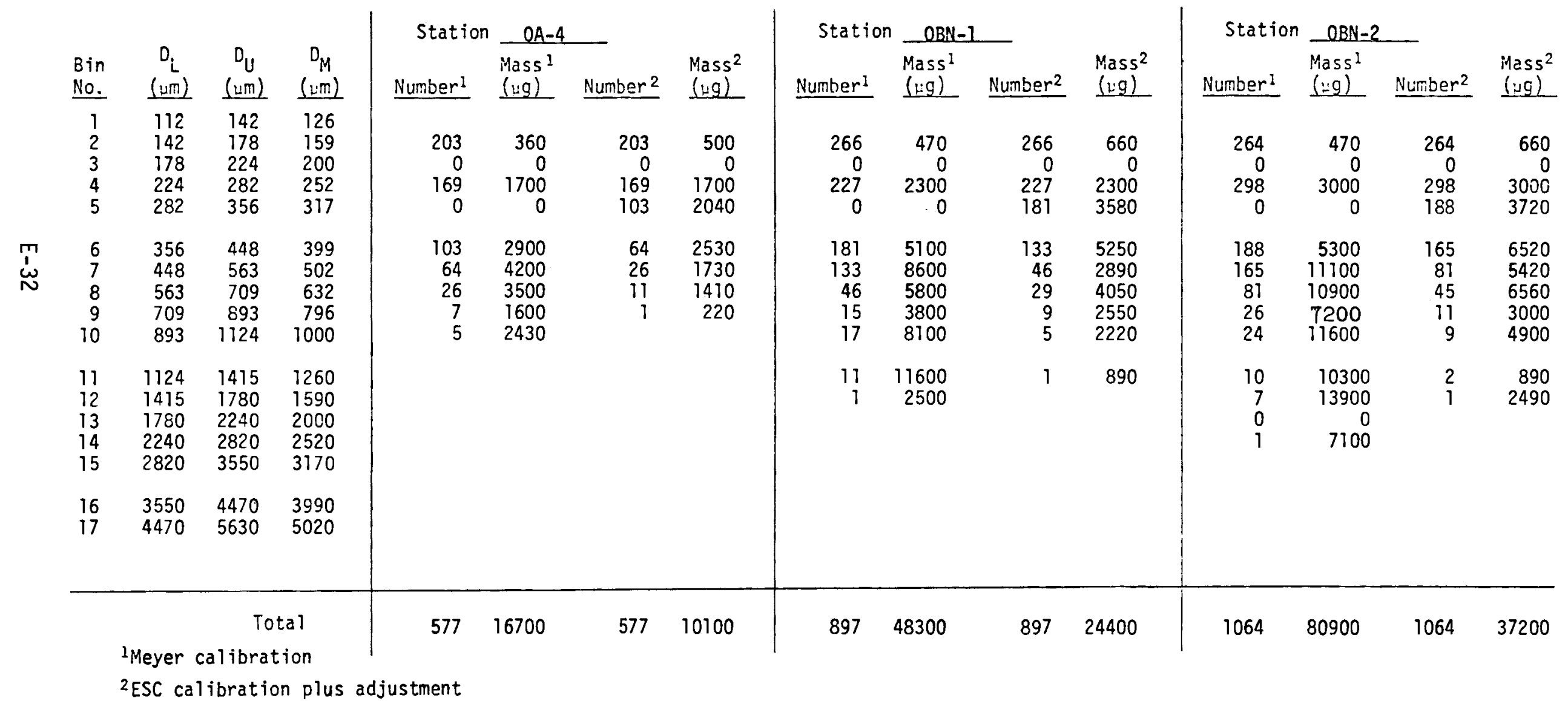


TABLE E1.6. (Continued)

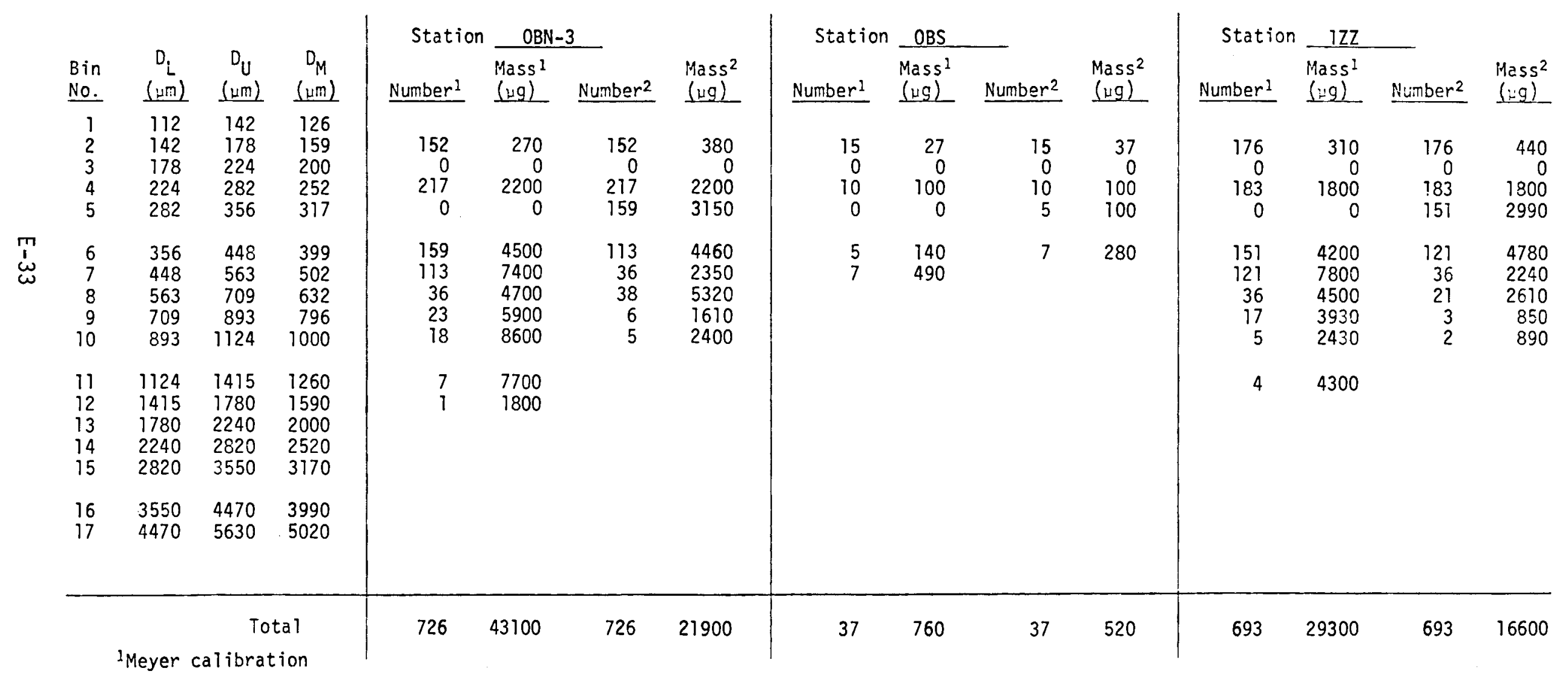

2ESC calibration plus adjustment 
TABLE EI.6. (Continued)

\begin{tabular}{|c|c|c|c|c|c|c|c|c|c|c|c|c|c|c|c|}
\hline \multirow[b]{2}{*}{$\begin{array}{l}\text { Bin } \\
\text { No. }\end{array}$} & \multirow[b]{2}{*}{$\begin{array}{c}D_{L} \\
(\mu \mathrm{m})\end{array}$} & \multirow[b]{2}{*}{$\begin{array}{c}D_{U} \\
(\mu \mathrm{m})\end{array}$} & \multirow[b]{2}{*}{$\begin{array}{c}D_{M} \\
(\mu \mathrm{m}) \\
\end{array}$} & \multirow{2}{*}{$\begin{array}{l}\text { Station } \\
\text { Number } 1 \\
\end{array}$} & \multicolumn{2}{|l|}{12} & \multirow[b]{2}{*}{$\begin{array}{l}\text { Mass }^{2} \\
(\mu \mathrm{g})\end{array}$} & \multirow{2}{*}{$\begin{array}{r}\text { Station } \\
\text { Number } 1 \\
\end{array}$} & \multicolumn{2}{|l|}{$1 Y-1$} & \multirow[b]{2}{*}{$\begin{array}{l}\text { Mass }^{2} \\
(\mu \mathrm{g}) \\
\end{array}$} & \multirow{2}{*}{$\begin{array}{r}\text { Station } \\
\text { Numberl } \\
\end{array}$} & \multicolumn{2}{|l|}{$1 Y-2$} & \multirow[b]{2}{*}{$\begin{array}{l}\text { Mass }^{2} \\
(u g)\end{array}$} \\
\hline & & & & & $\begin{array}{l}\text { Mass }{ }^{1} \\
(\mu g)\end{array}$ & Number ${ }^{2}$ & & & $\begin{array}{l}\text { Mass }^{1} \\
(1: g)\end{array}$ & Number ${ }^{2}$ & & & $\begin{array}{l}\text { Mass } \\
(29)\end{array}$ & Number ${ }^{2}$ & \\
\hline $\begin{array}{l}1 \\
2 \\
3 \\
4 \\
5\end{array}$ & $\begin{array}{l}112 \\
142 \\
178 \\
224 \\
282\end{array}$ & $\begin{array}{l}142 \\
178 \\
224 \\
282 \\
356\end{array}$ & $\begin{array}{l}126 \\
159 \\
200 \\
252 \\
317\end{array}$ & $\begin{array}{r}84 \\
0 \\
92 \\
0\end{array}$ & $\begin{array}{r}150 \\
0 \\
920 \\
0\end{array}$ & $\begin{array}{r}84 \\
0 \\
42 \\
49\end{array}$ & $\begin{array}{r}210 \\
0 \\
920 \\
970\end{array}$ & $\begin{array}{r}127 \\
0 \\
264 \\
0\end{array}$ & $\begin{array}{r}230 \\
0 \\
2640 \\
0\end{array}$ & $\begin{array}{r}127 \\
0 \\
264 \\
179\end{array}$ & $\begin{array}{r}320 \\
0 \\
2640 \\
3540\end{array}$ & $\begin{array}{r}267 \\
0 \\
185 \\
0\end{array}$ & $\begin{array}{r}470 \\
0 \\
1850 \\
0\end{array}$ & $\begin{array}{r}267 \\
0 \\
185 \\
111\end{array}$ & $\begin{array}{r}660 \\
0 \\
1850 \\
2200\end{array}$ \\
\hline $\begin{array}{r}6 \\
7 \\
8 \\
9 \\
10\end{array}$ & $\begin{array}{l}356 \\
448 \\
563 \\
709 \\
893\end{array}$ & $\begin{array}{r}448 \\
563 \\
709 \\
893 \\
1124\end{array}$ & $\begin{array}{r}399 \\
502 \\
632 \\
796 \\
1000\end{array}$ & $\begin{array}{r}49 \\
47 \\
5 \\
2 \\
2\end{array}$ & $\begin{array}{r}1400 \\
3100 \\
660 \\
540 \\
1080\end{array}$ & $\begin{array}{r}47 \\
5 \\
3 \\
1\end{array}$ & $\begin{array}{r}1860 \\
320 \\
430 \\
220\end{array}$ & $\begin{array}{r}179 \\
104 \\
28 \\
8 \\
2\end{array}$ & $\begin{array}{r}5000 \\
7000 \\
3700 \\
1930 \\
890\end{array}$ & $\begin{array}{r}104 \\
28 \\
10\end{array}$ & $\begin{array}{l}4110 \\
1840 \\
1300\end{array}$ & $\begin{array}{r}111 \\
88 \\
24 \\
8 \\
2\end{array}$ & $\begin{array}{l}3100 \\
5700 \\
3200 \\
2270 \\
1080\end{array}$ & $\begin{array}{r}88 \\
24 \\
9 \\
1 \\
.7\end{array}$ & $\begin{array}{r}3480 \\
1590 \\
1280 \\
220 \\
440\end{array}$ \\
\hline $\begin{array}{l}11 \\
12 \\
13 \\
14 \\
15\end{array}$ & $\begin{array}{l}1124 \\
1415 \\
1780 \\
2240 \\
2820\end{array}$ & $\begin{array}{l}1415 \\
1780 \\
2240 \\
2820 \\
3550\end{array}$ & $\begin{array}{l}1260 \\
1590 \\
2000 \\
2520 \\
3170\end{array}$ & & & & & & & & & 1 & 1300 & & \\
\hline $\begin{array}{l}16 \\
17\end{array}$ & $\begin{array}{l}3550 \\
4470\end{array}$ & $\begin{array}{l}4470 \\
5630\end{array}$ & $\begin{array}{l}3990 \\
5020\end{array}$ & & & & & & & & & & & & \\
\hline & & & & 281 & 7850 & 281 & 4930 & 712 & 21400 & 712 & 12800 & 686 & 18900 & 682 & 11700 \\
\hline
\end{tabular}

${ }^{2}$ ESC calibration plus adjustment 
TABLE El.6. (Continued)

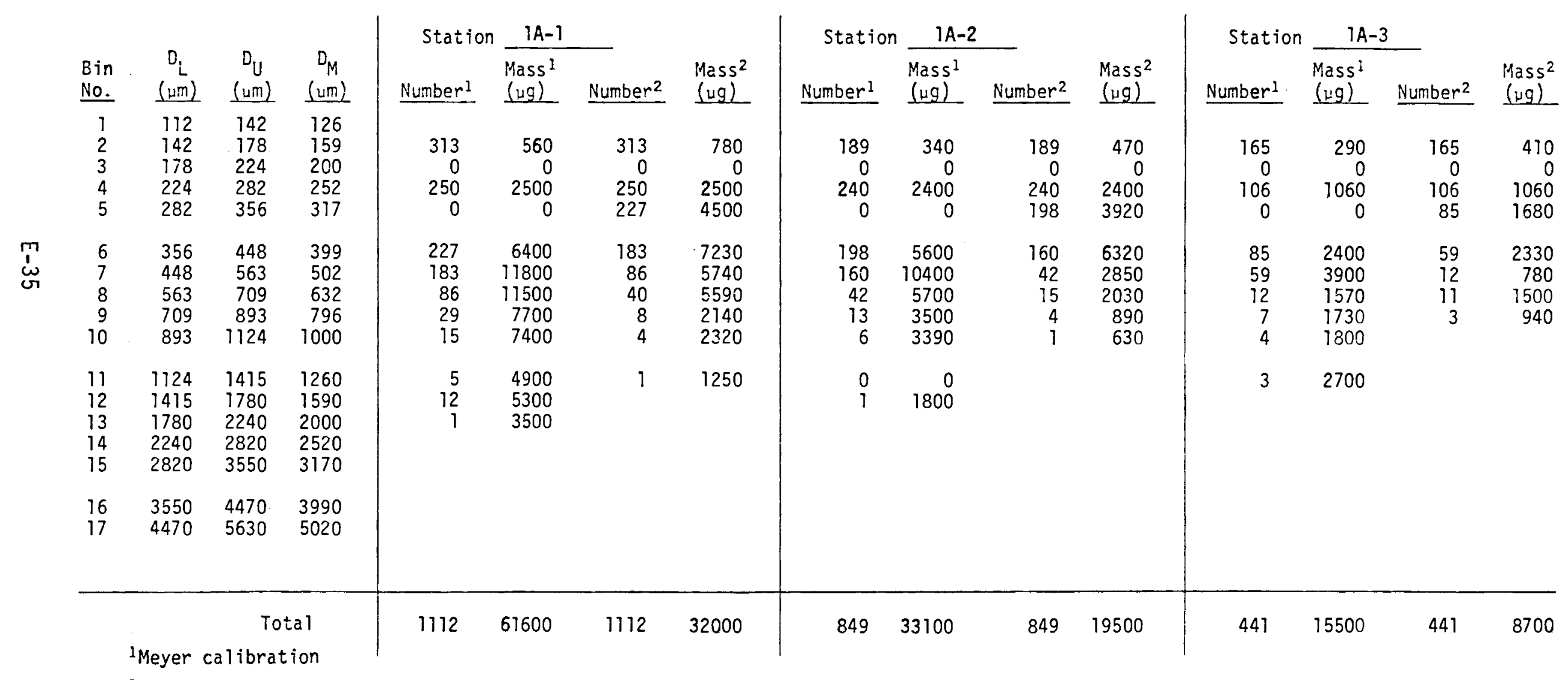

${ }^{2}$ ESC calibration plus adjustment 
TABLE E1.6. (Continued)

\begin{tabular}{|c|c|c|c|c|c|c|c|c|c|c|c|c|c|c|c|}
\hline \multirow[b]{2}{*}{$\begin{array}{l}\text { Bin } \\
\text { No. }\end{array}$} & \multirow[b]{2}{*}{$\begin{array}{c}D_{L} \\
(\mu m) \\
\end{array}$} & \multirow[b]{2}{*}{$\begin{array}{c}D_{u} \\
\text { (um) }\end{array}$} & \multirow[b]{2}{*}{$\begin{array}{c}D_{M} \\
(\mu \mathrm{m}) \\
\end{array}$} & \multirow{2}{*}{$\begin{array}{l}\text { Station } \\
\text { Number } \\
\end{array}$} & \multicolumn{2}{|c|}{$1 \mathrm{~B}-1$} & \multirow[b]{2}{*}{$\begin{array}{l}\text { Mass }^{2} \\
(\mu g)\end{array}$} & \multirow{2}{*}{$\begin{array}{l}\text { Station } \\
\text { Number } \\
\end{array}$} & \multicolumn{2}{|c|}{$1 \mathrm{~B}-2$} & \multirow[b]{2}{*}{$\begin{array}{c}\text { Mass }^{2} \\
(\mu g) \\
\end{array}$} & \multirow{2}{*}{$\begin{array}{r}\text { Station } \\
\text { Number1 } \\
\end{array}$} & \multicolumn{2}{|l|}{$-1 \mathrm{~B}-3$} & \multirow[b]{2}{*}{$\begin{array}{l}\text { Mass }^{2} \\
(\mathrm{ig}) \\
\end{array}$} \\
\hline & & & & & $\begin{array}{l}\text { Mass }^{3} \\
(\mu g)\end{array}$ & Number ${ }^{2}$ & & & $\begin{array}{l}\text { Mass }{ }^{1} \\
(\mu g)\end{array}$ & Number ${ }^{2}$ & & & $\begin{array}{l}\text { Mass } 1 \\
(y g)\end{array}$ & Number ${ }^{2}$ & \\
\hline $\begin{array}{l}1 \\
2 \\
3 \\
4 \\
5\end{array}$ & $\begin{array}{l}112 \\
142 \\
178 \\
224 \\
282\end{array}$ & $\begin{array}{l}142 \\
178 \\
224 \\
282 \\
356\end{array}$ & $\begin{array}{l}126 \\
159 \\
200 \\
252 \\
317\end{array}$ & $\begin{array}{r}170 \\
0 \\
183 \\
0\end{array}$ & $\begin{array}{r}300 \\
0 \\
1800 \\
0\end{array}$ & $\begin{array}{r}170 \\
0 \\
183 \\
146\end{array}$ & $\begin{array}{r}420 \\
0 \\
1800 \\
2890\end{array}$ & $\begin{array}{r}326 \\
0 \\
241 \\
0\end{array}$ & $\begin{array}{r}580 \\
0 \\
2400 \\
0\end{array}$ & $\begin{array}{r}326 \\
0 \\
241 \\
177\end{array}$ & $\begin{array}{r}810 \\
0 \\
2400 \\
3500\end{array}$ & $\begin{array}{r}161 \\
0 \\
171 \\
0\end{array}$ & $\begin{array}{r}290 \\
0 \\
1700 \\
0\end{array}$ & $\begin{array}{r}161 \\
0 \\
171 \\
157\end{array}$ & $\begin{array}{r}400 \\
0 \\
1700 \\
3110\end{array}$ \\
\hline $\begin{array}{r}6 \\
7 \\
8 \\
9 \\
10\end{array}$ & $\begin{array}{l}356 \\
448 \\
563 \\
709 \\
893\end{array}$ & $\begin{array}{r}448 \\
563 \\
709 \\
893 \\
1124\end{array}$ & $\begin{array}{r}399 \\
502 \\
632 \\
796 \\
1000\end{array}$ & $\begin{array}{r}146 \\
89 \\
35 \\
21 \\
16\end{array}$ & $\begin{array}{l}4100 \\
5900 \\
4500 \\
5700 \\
8300\end{array}$ & $\begin{array}{r}89 \\
35 \\
31 \\
10 \\
4\end{array}$ & $\begin{array}{l}3520 \\
2230 \\
4360 \\
2590 \\
1960\end{array}$ & $\begin{array}{r}177 \\
169 \\
51 \\
32 \\
23\end{array}$ & $\begin{array}{r}5000 \\
10800 \\
6800 \\
8300 \\
11400\end{array}$ & $\begin{array}{r}169 \\
51 \\
49 \\
17 \\
5\end{array}$ & $\begin{array}{l}6680 \\
3420 \\
6770 \\
4790 \\
2220\end{array}$ & $\begin{array}{r}157 \\
171 \\
64 \\
25 \\
26\end{array}$ & $\begin{array}{r}4400 \\
11100 \\
8600 \\
6600 \\
13300\end{array}$ & $\begin{array}{r}171 \\
64 \\
42 \\
14 \\
4\end{array}$ & $\begin{array}{l}6750 \\
4280 \\
4400 \\
3570 \\
1960\end{array}$ \\
\hline $\begin{array}{l}11 \\
12 \\
13 \\
14 \\
15\end{array}$ & $\begin{array}{l}1124 \\
1415 \\
1780 \\
2240 \\
2820\end{array}$ & $\begin{array}{l}1415 \\
1780 \\
2240 \\
2820 \\
3550\end{array}$ & $\begin{array}{l}1260 \\
1590 \\
2000 \\
2520 \\
3170\end{array}$ & $\begin{array}{l}7 \\
1\end{array}$ & $\begin{array}{l}7400 \\
1800\end{array}$ & & & $\begin{array}{r}16 \\
1 \\
1\end{array}$ & $\begin{array}{r}16100 \\
2500 \\
3500\end{array}$ & 2 & 2130 & $\begin{array}{l}8 \\
2 \\
3\end{array}$ & $\begin{array}{r}8200 \\
4300 \\
10000\end{array}$ & 4 & 4640 \\
\hline $\begin{array}{l}16 \\
17\end{array}$ & $\begin{array}{l}3550 \\
4470\end{array}$ & $\begin{array}{l}4470 \\
5630\end{array}$ & $\begin{array}{l}3990 \\
5020\end{array}$ & & & & & & & & & & & & \\
\hline & & & & 668 & 39800 & 668 & 19800 & 1037 & 67400 & 1037 & 32700 & 788 & 69500 & 788 & 30800 \\
\hline
\end{tabular}

${ }^{2}$ ESC calibration plus adjustment 
TABLE E1.6. (Continued)

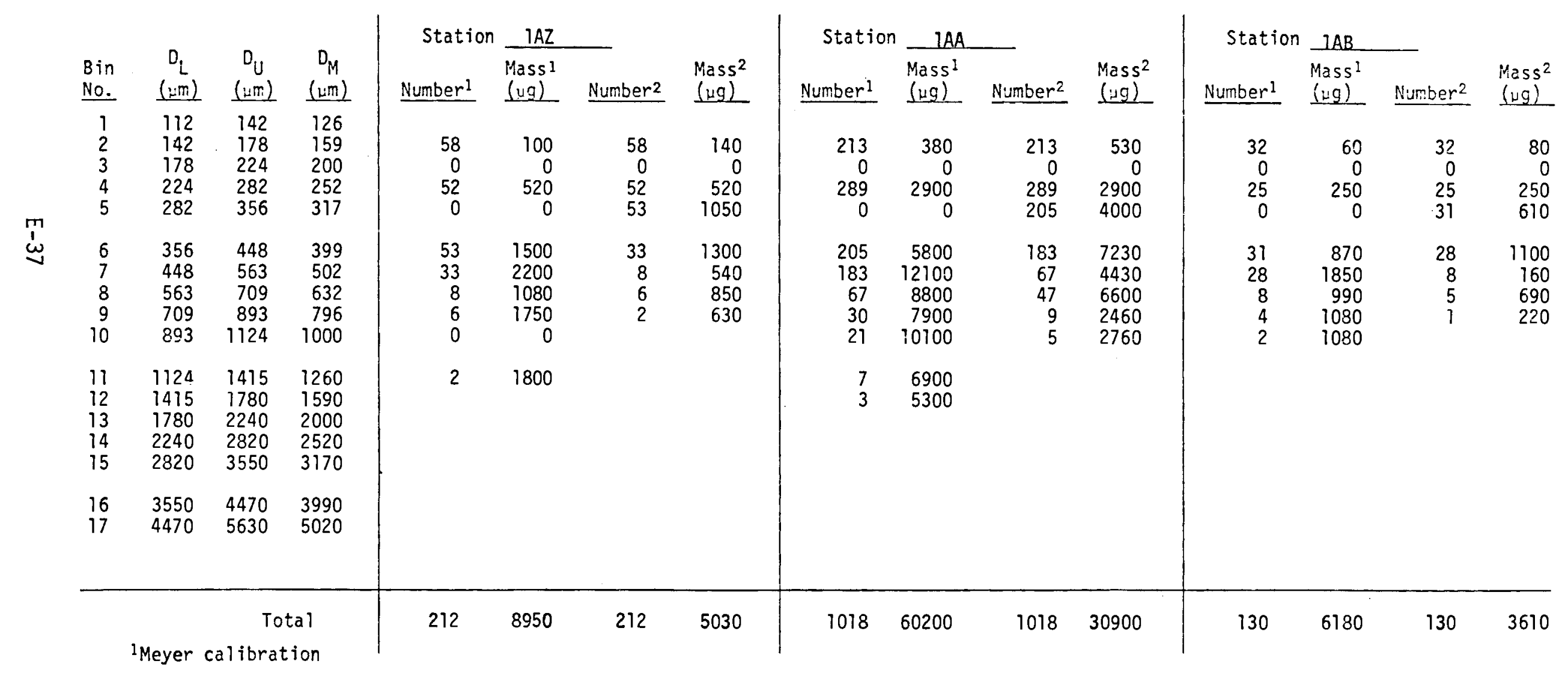

${ }^{2}$ ESC calibration plus adjustment 
TABLE ET.6. (Continued)

\begin{tabular}{|c|c|c|c|c|c|c|c|c|c|c|c|c|c|c|c|}
\hline \multirow[b]{2}{*}{$\begin{array}{l}\text { Bin } \\
\text { No. }\end{array}$} & \multirow[b]{2}{*}{ 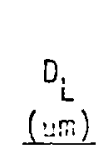 } & \multirow[b]{2}{*}{$\underset{(\mathrm{U})}{\left.\mathrm{D}_{\mathrm{U}}\right)}$} & \multirow[b]{2}{*}{$\begin{array}{c}D_{M} \\
(\mathrm{~nm}) \\
\end{array}$} & \multirow{2}{*}{$\begin{array}{r}\text { Station } \\
\text { lumberl } \\
\end{array}$} & \multicolumn{3}{|l|}{$2 A$} & \multirow{2}{*}{$\begin{array}{l}\text { Station } \\
\text { Number } \\
\end{array}$} & \multicolumn{2}{|l|}{$2 B$} & \multirow[b]{2}{*}{$\begin{array}{c}\operatorname{Mass}^{2} \\
(n g)\end{array}$} & \multirow{2}{*}{$\begin{array}{l}\text { Station } \\
\text { Number? }\end{array}$} & \multicolumn{3}{|c|}{$0 A-1 \quad(T i\rceil t)$} \\
\hline & & & & & $\begin{array}{l}\text { Mass } 1 \\
\text { (ug) }\end{array}$ & Number 2 & $\begin{array}{l}\text { Mass }^{2} \\
(\because g)\end{array}$ & & $\begin{array}{l}\text { Mass } \\
(\underline{L} S)\end{array}$ & Number ${ }^{2}$ & & & $\begin{array}{l}M a s s^{2} \\
(-g)\end{array}$ & Number 3 & $\begin{array}{l}\text { Mass }^{3} \\
(\text { ugl }\end{array}$ \\
\hline $\begin{array}{l}1 \\
2 \\
3 \\
4 \\
5\end{array}$ & $\begin{array}{l}112 \\
142 \\
178 \\
224 \\
282\end{array}$ & $\begin{array}{l}142 \\
178 \\
224 \\
282 \\
356\end{array}$ & $\begin{array}{l}126 \\
159 \\
200 \\
252 \\
317\end{array}$ & $\begin{array}{r}34 \\
0 \\
39 \\
0\end{array}$ & $\begin{array}{r}60 \\
0 \\
390 \\
0\end{array}$ & $\begin{array}{r}34 \\
0 \\
39 \\
30\end{array}$ & $\begin{array}{r}80 \\
0 \\
390 \\
590\end{array}$ & $\begin{array}{r}51 \\
0 \\
94 \\
0\end{array}$ & $\begin{array}{r}90 \\
0 \\
940 \\
0\end{array}$ & $\begin{array}{r}51 \\
0 \\
94 \\
79\end{array}$ & $\begin{array}{r}130 \\
0 \\
940 \\
1560\end{array}$ & $\begin{array}{r}91 \\
0 \\
470 \\
0\end{array}$ & $\begin{array}{r}160 \\
0 \\
4700 \\
0\end{array}$ & $\begin{array}{r}91 \\
0 \\
470 \\
0 \\
370\end{array}$ & $\begin{array}{r}80 \\
0 \\
2340 \\
0 \\
5180\end{array}$ \\
\hline $\begin{array}{r}6 \\
7 \\
8 \\
9 \\
10\end{array}$ & $\begin{array}{l}356 \\
448 \\
563 \\
709 \\
893\end{array}$ & $\begin{array}{r}448 \\
563 \\
709 \\
893 \\
1124\end{array}$ & $\begin{array}{r}399 \\
502 \\
632 \\
796 \\
1000\end{array}$ & $\begin{array}{r}30 \\
21 \\
6 \\
2 \\
10\end{array}$ & $\begin{array}{r}840 \\
1360 \\
770 \\
450 \\
1080\end{array}$ & $\begin{array}{r}21 \\
6 \\
3 \\
1\end{array}$ & $\begin{array}{l}830 \\
380 \\
380 \\
220\end{array}$ & $\begin{array}{r}79 \\
70 \\
12 \\
14 \\
6\end{array}$ & $\begin{array}{l}2200 \\
4400 \\
1470 \\
3600 \\
3200\end{array}$ & $\begin{array}{r}70 \\
12 \\
17 \\
6 \\
2\end{array}$ & $\begin{array}{r}2760 \\
740 \\
2260 \\
1610 \\
630\end{array}$ & $\begin{array}{r}370 \\
260 \\
93 \\
28 \\
11\end{array}$ & $\begin{array}{r}10000 \\
17000 \\
12000 \\
7400 \\
5500\end{array}$ & $\begin{array}{r}260 \\
93 \\
28 \\
11 \\
8\end{array}$ & $\begin{array}{l}8470 \\
5970 \\
3710 \\
2720 \\
3910\end{array}$ \\
\hline $\begin{array}{l}11 \\
12 \\
13 \\
14 \\
15\end{array}$ & $\begin{array}{l}1124 \\
1415 \\
1780 \\
2240 \\
2820\end{array}$ & $\begin{array}{l}1415 \\
1780 \\
2240 \\
2320 \\
3550\end{array}$ & $\begin{array}{l}1260 \\
1590 \\
2000 \\
2520 \\
3170\end{array}$ & & & & & $\begin{array}{l}3 \\
2\end{array}$ & $\begin{array}{l}2700 \\
3500\end{array}$ & & & $\begin{array}{l}8 \\
2\end{array}$ & $\begin{array}{l}7800 \\
3500\end{array}$ & 2 & 1770 \\
\hline $\begin{array}{l}16 \\
17\end{array}$ & $\begin{array}{l}3550 \\
4470\end{array}$ & $\begin{array}{l}4470 \\
5630\end{array}$ & $\begin{array}{l}3990 \\
5020\end{array}$ & & & & & & & & & & & & \\
\hline & & & & 134 & 4950 & 134 & 2870 & 331 & 22100 & 331 & 10600 & 1333 & 68100 & 1333 & 34200 \\
\hline
\end{tabular}

${ }^{2}$ ESC calibration plus adjustment

${ }^{3} \mathrm{ESC}$ calibration, $45^{\circ}$ impaction, $7.5 \mathrm{~m} \cdot \mathrm{s}^{-1}$ 
TABLE El.6. (Continued)

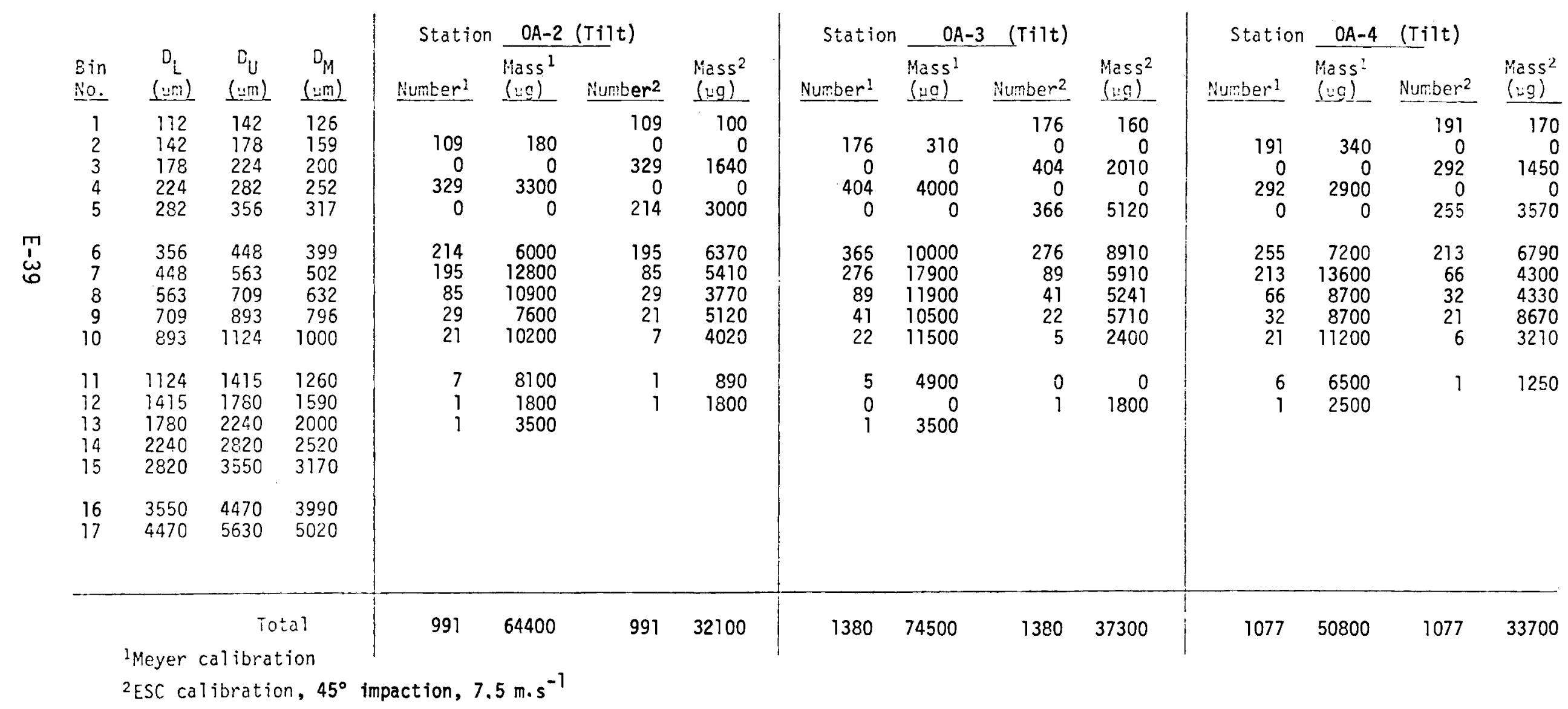


TABLE E].6. (Continued)

\begin{tabular}{|c|c|c|c|c|c|c|c|c|c|c|c|c|c|c|c|}
\hline \multirow[b]{2}{*}{$\begin{array}{l}\text { Bin } \\
\text { No. }\end{array}$} & \multirow[b]{2}{*}{$\begin{array}{c}D_{\mathrm{L}} \\
\text { (uni) }\end{array}$} & \multirow[b]{2}{*}{$\begin{array}{c}D_{U} \\
(\leq n)\end{array}$} & \multirow[b]{2}{*}{$\begin{array}{c}D_{M} \\
(u m) \\
\end{array}$} & \multirow{2}{*}{$\begin{array}{l}\text { Station } \\
\text { Number }\end{array}$} & \multicolumn{2}{|c|}{ IA (Tilt) } & \multirow[b]{2}{*}{$\begin{array}{l}\operatorname{Mess}^{2} \\
(n g)\end{array}$} & \multirow{2}{*}{$\begin{array}{r}\text { Statio } \\
\text { Number! } \\
\end{array}$} & \multicolumn{2}{|c|}{$1 B-1 \quad(T i] t)$} & \multirow[b]{2}{*}{$\begin{array}{c}\operatorname{Mass}^{2} \\
(:: g)\end{array}$} & \multirow{2}{*}{$\begin{array}{r}\text { Statio } \\
\text { Number } \\
\end{array}$} & \multicolumn{2}{|c|}{ IB-2 (Tilt). } & \multirow[b]{2}{*}{$\begin{array}{l}\text { Mass }^{2} \\
\text { (ug) }\end{array}$} \\
\hline & & & & & $\begin{array}{l}\text { Mass } \\
\text { (ug) }\end{array}$ & Number ${ }^{2}$ & & & $\begin{array}{l}\text { Mass } 1 \\
\underline{(\mu g)}\end{array}$ & Number ${ }^{2}$ & & & $\begin{array}{l}\text { Mass: } \\
(\because: 9)\end{array}$ & Number ${ }^{2}$ & \\
\hline $\begin{array}{l}3 \\
2 \\
3 \\
4 \\
5\end{array}$ & $\begin{array}{l}112 \\
142 \\
178 \\
224 \\
282\end{array}$ & $\begin{array}{l}142 \\
178 \\
224 \\
282 \\
356\end{array}$ & $\begin{array}{l}126 \\
159 \\
200 \\
252 \\
317\end{array}$ & $\begin{array}{r}231 \\
0 \\
233 \\
0\end{array}$ & $\begin{array}{r}410 \\
0 \\
2300 \\
0\end{array}$ & $\begin{array}{r}231 \\
0 \\
233 \\
0 \\
217\end{array}$ & $\begin{array}{r}200 \\
0 \\
1160 \\
0 \\
3040\end{array}$ & $\begin{array}{r}328 \\
0 \\
348 \\
0\end{array}$ & $\begin{array}{r}580 \\
0 \\
3500 \\
0\end{array}$ & $\begin{array}{r}328 \\
0 \\
348 \\
0 \\
319\end{array}$ & $\begin{array}{r}290 \\
0 \\
1730 \\
0 \\
4470\end{array}$ & $\begin{array}{r}222 \\
0 \\
215 \\
0\end{array}$ & $\begin{array}{r}390 \\
0 \\
2100 \\
0\end{array}$ & $\begin{array}{r}222 \\
0 \\
215 \\
0 \\
185\end{array}$ & $\begin{array}{r}200 \\
0 \\
1070 \\
0 \\
2590\end{array}$ \\
\hline $\begin{array}{r}6 \\
7 \\
8 \\
9 \\
10\end{array}$ & $\begin{array}{l}356 \\
448 \\
563 \\
709 \\
893\end{array}$ & $\begin{array}{r}448 \\
563 \\
709 \\
893 \\
1124\end{array}$ & $\begin{array}{r}399 \\
502 \\
632 \\
796 \\
1000\end{array}$ & $\begin{array}{r}217 \\
253 \\
76 \\
35 \\
18\end{array}$ & $\begin{array}{r}6100 \\
16300 \\
10200 \\
9400 \\
8900\end{array}$ & $\begin{array}{r}253 \\
76 \\
35 \\
18 \\
3\end{array}$ & $\begin{array}{l}8170 \\
5070 \\
4670 \\
4460 \\
1510\end{array}$ & $\begin{array}{r}319 \\
329 \\
133 \\
65 \\
51\end{array}$ & $\begin{array}{r}9000 \\
21000 \\
17300 \\
17100 \\
24500\end{array}$ & $\begin{array}{r}329 \\
133 \\
65 \\
51 \\
21\end{array}$ & $\begin{array}{r}10700 \\
8640 \\
8730 \\
12400 \\
12000\end{array}$ & $\begin{array}{r}185 \\
239 \\
104 \\
60 \\
40\end{array}$ & $\begin{array}{r}5200 \\
16200 \\
13500 \\
15600 \\
20400\end{array}$ & $\begin{array}{r}239 \\
104 \\
60 \\
40 \\
10\end{array}$ & $\begin{array}{r}8070 \\
6750 \\
7750 \\
10300 \\
5350\end{array}$ \\
\hline $\begin{array}{l}11 \\
12 \\
13 \\
14 \\
15\end{array}$ & $\begin{array}{l}1124 \\
1415 \\
1780 \\
2240 \\
2820\end{array}$ & $\begin{array}{l}1415 \\
1780 \\
2240 \\
2820 \\
3550\end{array}$ & $\begin{array}{l}1260 \\
1590 \\
2000 \\
2520 \\
3170\end{array}$ & $\begin{array}{l}3 \\
1\end{array}$ & $\begin{array}{l}3100 \\
1800\end{array}$ & 1 & 890 & $\begin{array}{r}21 \\
10 \\
2 \\
1\end{array}$ & $\begin{array}{r}24300 \\
19000 \\
7100 \\
7100\end{array}$ & $\begin{array}{r}10 \\
2 \\
1\end{array}$ & $\begin{array}{l}9570 \\
1800 \\
3500\end{array}$ & $\begin{array}{r}10 \\
10 \\
6\end{array}$ & $\begin{array}{l}10700 \\
22100 \\
26000\end{array}$ & $\begin{array}{r}10 \\
6\end{array}$ & $\begin{array}{l}11000 \\
12900\end{array}$ \\
\hline $\begin{array}{l}16 \\
17\end{array}$ & $\begin{array}{l}3550 \\
4470\end{array}$ & $\begin{array}{l}4470 \\
5630\end{array}$ & $\begin{array}{l}3990 \\
5020\end{array}$ & & & & & & & & & & & & \\
\hline & & & & 1067 & 58500 & 1067 & 29200 & 1607 & 150000 & 1607 & 61800 & ו & 132000 & 1091 & 56100 \\
\hline
\end{tabular}


TABLE E1.6. (Continued)

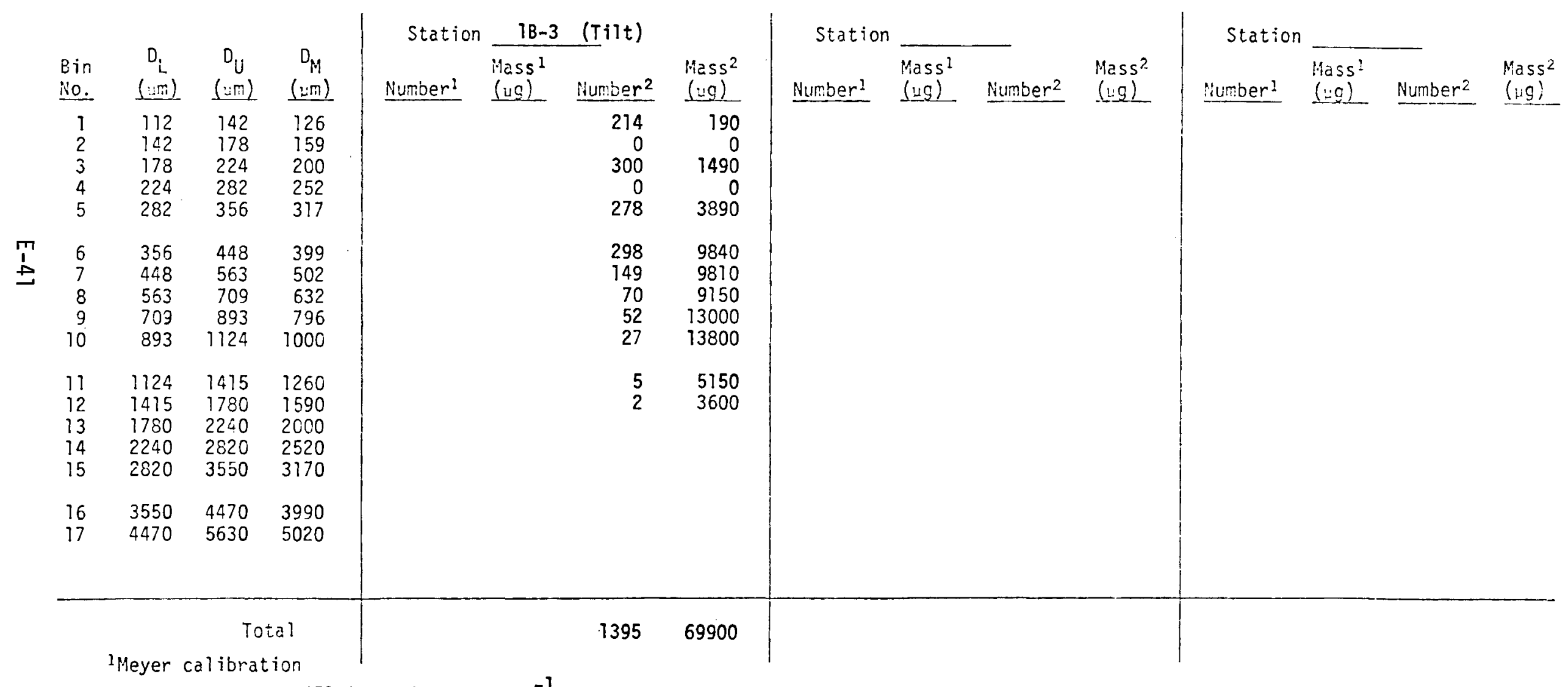

${ }^{2} \mathrm{ESC}$ calibration, $45^{\circ}$ impaction, $7.5 \mathrm{~m} \cdot \mathrm{s}^{-1}$ 
TABLE El.X. Drift Droplet Deposition Spectra, Test Run X, 25 June 1978 (Near Field Test)

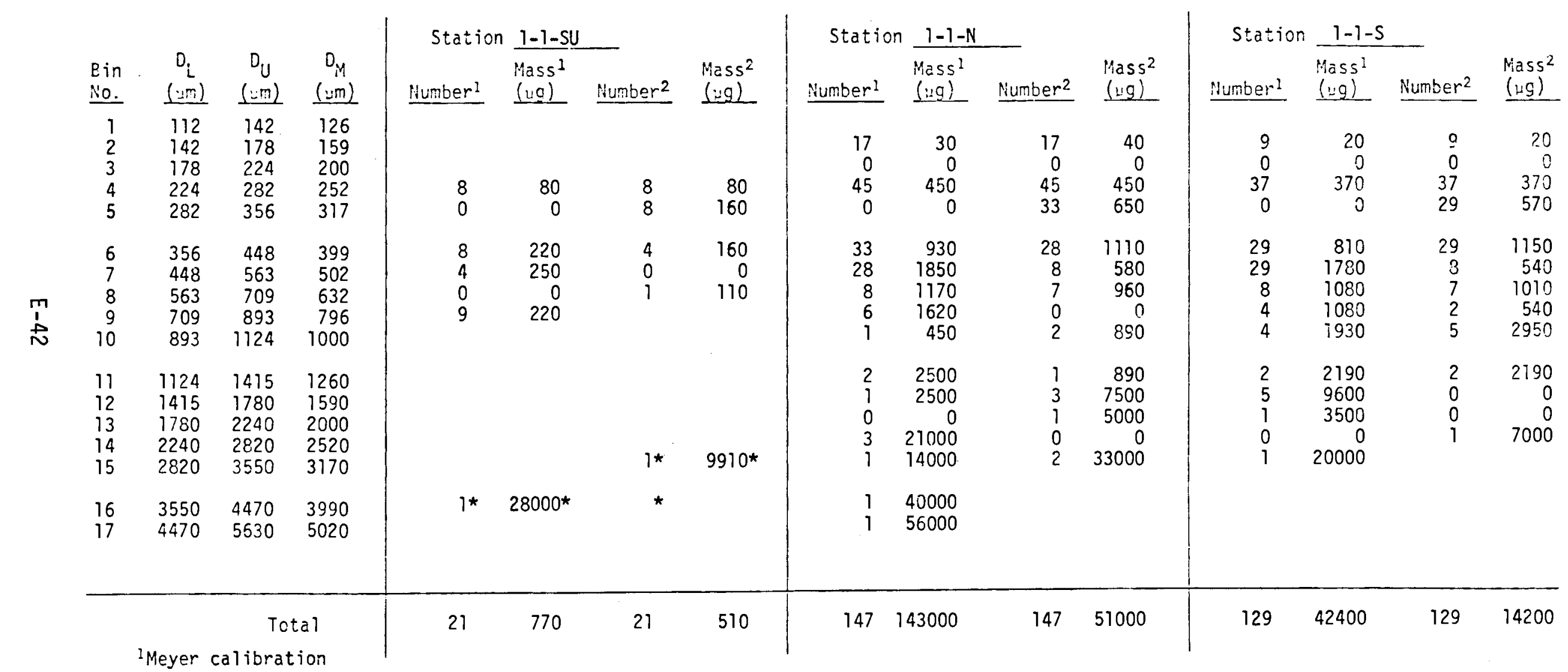

2ESC calibration plus adjustment

* Not included in total 
TABLE E1.X. (Continued)

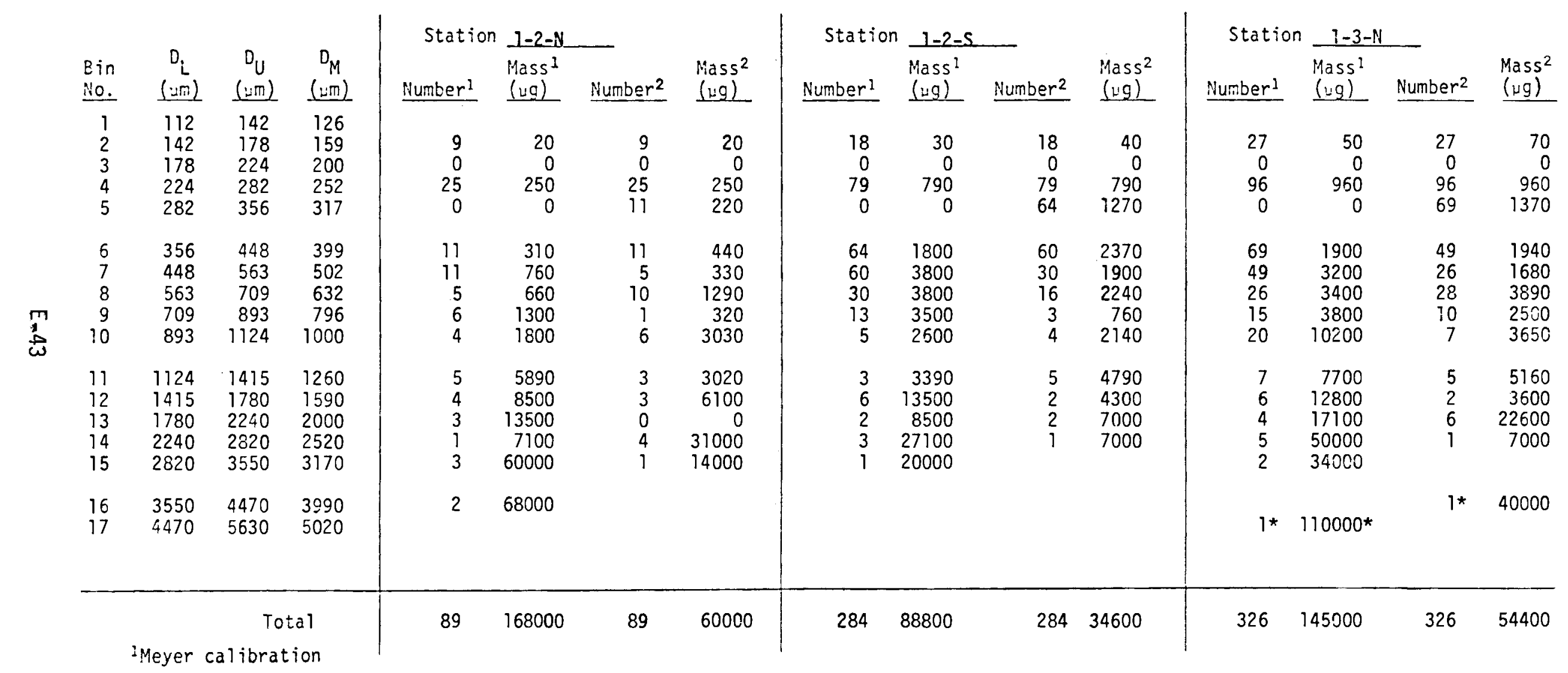

${ }^{2}$ ESC calibration plus adjustment

* Not included in total 
TABLE EI.X. (Continued)

\begin{tabular}{|c|c|c|c|c|c|c|c|c|c|c|c|c|c|c|c|}
\hline \multirow[b]{2}{*}{$\begin{array}{l}\text { Bin } \\
\text { No. } \\
\end{array}$} & \multirow[b]{2}{*}{$\begin{array}{c}D_{i} \\
\text { (um) }\end{array}$} & \multirow[b]{2}{*}{$\begin{array}{c}D_{U} \\
(L m) \\
\end{array}$} & \multirow[b]{2}{*}{$\begin{array}{c}D_{M} \\
(\mu m) \\
\end{array}$} & \multirow{2}{*}{$\begin{array}{r}\text { Station } \\
\text { Number } \\
\end{array}$} & \multicolumn{2}{|c|}{$1-3-5$} & \multirow[b]{2}{*}{$\begin{array}{l}\text { Mass }^{2} \\
(\mu \mathrm{g})\end{array}$} & \multirow{2}{*}{$\begin{array}{r}\text { Station } \\
\text { Number! } \\
\end{array}$} & \multicolumn{2}{|c|}{$1-4-N$} & \multirow[b]{2}{*}{$\begin{array}{l}\text { Mass }^{2} \\
(\mu g)\end{array}$} & \multirow{2}{*}{$\begin{array}{r}\text { Station } \\
\text { Numberl } \\
\end{array}$} & \multicolumn{2}{|c|}{$1-7-N$} & \multirow[b]{2}{*}{$\begin{array}{l}\text { Mass }^{2} \\
(\mu \mathrm{g})\end{array}$} \\
\hline & & & & & $\begin{array}{l}\text { Mass }{ }^{2} \\
\text { (ug) }\end{array}$ & Number ${ }^{2}$ & & & $\begin{array}{l}\text { Mass } \\
(\mu g)\end{array}$ & Number ${ }^{2}$ & & & $\begin{array}{l}\text { Mass } \\
\text { (ug) } \\
\end{array}$ & Number ${ }^{2}$ & \\
\hline $\begin{array}{l}1 \\
2 \\
3 \\
4 \\
5\end{array}$ & $\begin{array}{l}112 \\
142 \\
178 \\
224 \\
282\end{array}$ & $\begin{array}{l}142 \\
178 \\
224 \\
282 \\
356\end{array}$ & $\begin{array}{l}126 \\
159 \\
200 \\
252 \\
317\end{array}$ & $\begin{array}{r}27 \\
0 \\
68 \\
0\end{array}$ & $\begin{array}{r}50 \\
0 \\
680 \\
0\end{array}$ & $\begin{array}{r}27 \\
0 \\
68 \\
54\end{array}$ & $\begin{array}{r}70 \\
0 \\
680 \\
1070\end{array}$ & $\begin{array}{r}16 \\
0 \\
61 \\
0\end{array}$ & $\begin{array}{r}30 \\
0 \\
610 \\
0\end{array}$ & $\begin{array}{r}16 \\
0 \\
61 \\
39\end{array}$ & $\begin{array}{r}40 \\
0 \\
610 \\
770\end{array}$ & $\begin{array}{r}2 \\
0 \\
15 \\
0\end{array}$ & $\begin{array}{r}4 \\
0 \\
150 \\
0\end{array}$ & $\begin{array}{r}2 \\
0 \\
15 \\
16\end{array}$ & $\begin{array}{r}5 \\
0 \\
150 \\
320\end{array}$ \\
\hline $\begin{array}{r}6 \\
7 \\
8 \\
9 \\
10\end{array}$ & $\begin{array}{l}356 \\
448 \\
563 \\
709 \\
893\end{array}$ & $\begin{array}{r}448 \\
563 \\
709 \\
893 \\
1124\end{array}$ & $\begin{array}{r}399 \\
502 \\
632 \\
796 \\
1000\end{array}$ & $\begin{array}{r}54 \\
32 \\
15 \\
12 \\
7\end{array}$ & $\begin{array}{l}1500 \\
1990 \\
1990 \\
2950 \\
3700\end{array}$ & $\begin{array}{r}32 \\
15 \\
16 \\
8 \\
3\end{array}$ & $\begin{array}{l}1260 \\
1000 \\
2100 \\
2240 \\
1700\end{array}$ & $\begin{array}{r}39 \\
24 \\
15 \\
7 \\
6\end{array}$ & $\begin{array}{l}1100 \\
1600 \\
2150 \\
1730 \\
3200\end{array}$ & $\begin{array}{r}24 \\
15 \\
10 \\
7 \\
5\end{array}$ & $\begin{array}{r}950 \\
1090 \\
1340 \\
1920 \\
2580\end{array}$ & $\begin{array}{r}16 \\
13 \\
9 \\
6 \\
8\end{array}$ & $\begin{array}{r}450 \\
820 \\
1240 \\
1520 \\
4300\end{array}$ & $\begin{array}{r}13 \\
9 \\
10 \\
8 \\
2\end{array}$ & $\begin{array}{r}510 \\
620 \\
1390 \\
2150 \\
1070\end{array}$ \\
\hline $\begin{array}{l}11 \\
12 \\
13 \\
14 \\
15\end{array}$ & $\begin{array}{l}1124 \\
1415 \\
1780 \\
2240 \\
2820\end{array}$ & $\begin{array}{l}1415 \\
1780 \\
2240 \\
2820 \\
3550\end{array}$ & $\begin{array}{l}1260 \\
1590 \\
2000 \\
2520 \\
3170\end{array}$ & $\begin{array}{l}6 \\
3 \\
4 \\
0 \\
1\end{array}$ & $\begin{array}{r}5700 \\
6000 \\
17100 \\
0 \\
14000\end{array}$ & $\begin{array}{l}3 \\
2 \\
1 \\
1 \\
1\end{array}$ & $\begin{array}{r}3390 \\
3500 \\
5000 \\
9900 \\
14000\end{array}$ & $\begin{array}{l}7 \\
3 \\
3 \\
4 \\
3\end{array}$ & $\begin{array}{r}7400 \\
6000 \\
14600 \\
34000 \\
54000\end{array}$ & $\begin{array}{l}3 \\
3 \\
3 \\
2\end{array}$ & $\begin{array}{r}3390 \\
6760 \\
14600 \\
14000\end{array}$ & $\begin{array}{l}5 \\
2 \\
2 \\
4\end{array}$ & $\begin{array}{r}4900 \\
4300 \\
8500 \\
37100\end{array}$ & $\begin{array}{l}2 \\
2 \\
3\end{array}$ & $\begin{array}{r}1140 \\
4300 \\
10600\end{array}$ \\
\hline $\begin{array}{l}16 \\
17\end{array}$ & $\begin{array}{l}3550 \\
4470\end{array}$ & $\begin{array}{l}4470 \\
5630\end{array}$ & $\begin{array}{l}3990 \\
5020\end{array}$ & 2 & 68000 & & & & & & & & & & \\
\hline & & & & 231 & 124000 & 231 & 45900 & 188 & 124000 & 188 & 48000 & 82 & 63300 & 82 & 22300 \\
\hline
\end{tabular}

${ }^{2}$ ESC calibration plus adjustment 
TABLE El.X. (Continued)

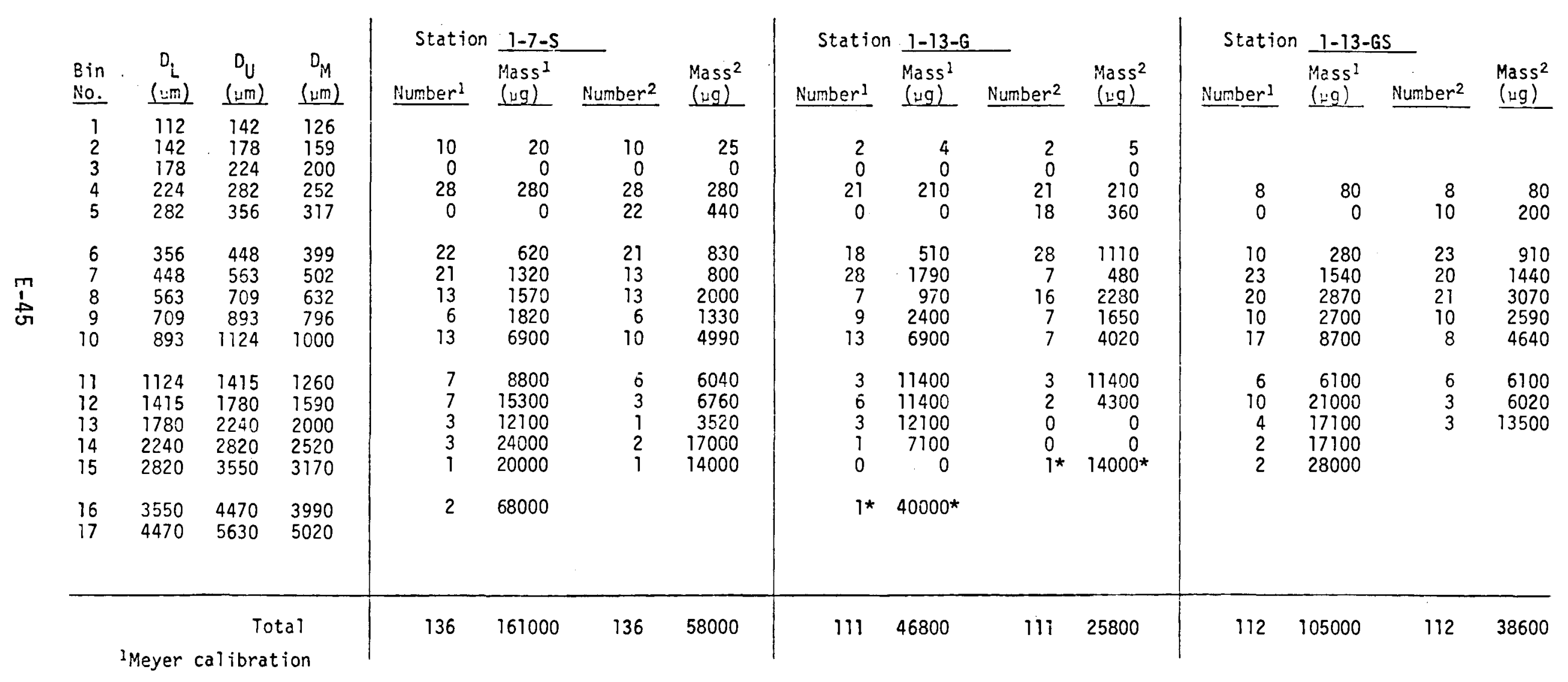

2 ESC calibration plus adjustment

* Not included in total 
TABLE E2.1. Drift Mineral Mass Deposition Rates, Test Run 1, 16 June 1978

Sample Interval

Sample Start Stop $\Delta t$ ID (PDT) (PDT) (hr)

UUA $0348 \quad 1152 \quad 3.07$

$\begin{array}{llll}\text { UUB } & 0852 & 1155 & 3.05\end{array}$

UA $\quad 0845 \quad 1150 \quad 3.08$

$\begin{array}{llll}\text { UB } & 0856 \quad 1157 \quad 3.02\end{array}$

$\begin{array}{llll}\text { OA } & 0840 & 1147 & 3.12 \\ \text { OBN } & 0830 & 1115 & 2.75\end{array}$

083511142.65

$\begin{array}{llll}0 \mathrm{Cl} & 0823 \quad 1110 & 2.78\end{array}$

$\begin{array}{llll}O C 2 & 0823 & 1110 & 2.78\end{array}$

OD $\quad$ CO24 11112.78

OE $0902 \quad 1201 \quad 2.98$

$\begin{array}{llll}1 A & 0820 & 1120 & 3.00\end{array}$

$\begin{array}{llll}1 \mathrm{~A} & 0816 \quad 1116 & 3.00\end{array}$

$\begin{array}{llll}1 \mathrm{Cl} & 0811 & 1110 & 2.98\end{array}$

IC2 $0811 \quad 11102.98$

1D) $0805 \quad 11042.98$

m 102

$\begin{array}{lll}0805 & 1104 & 2.98 \\ 0805 & 1104 & 2.98\end{array}$ $\begin{array}{lll}0805 & 1104 & 2.98 \\ 0747 & 1124 & 3.62\end{array}$ $\begin{array}{lll}0743 \quad 1129 & 3.77\end{array}$

$\begin{array}{lll}0743 & 1129 & 3.77\end{array}$

$\begin{array}{lll}0753 \quad 1117 & 3.40\end{array}$

$\begin{array}{lll}0912 & 1204 & 2.87\end{array}$

$0917 \quad 1213 \quad 2.93$

$\begin{array}{lll}0826 & 1134 & 3.13\end{array}$

$\begin{array}{lll}0831 & 1139 & 3.13 \\ 0804 & 1124 & 3.33\end{array}$

$\begin{array}{lll}0804 & 1124 & 3.33\end{array}$

$\begin{array}{lll}0805 & 1123 & 3.30\end{array}$

$\begin{array}{lll}0805 & 1123 & 3.30\end{array}$

$\begin{array}{lll}0810 & 1127 & 3.28\end{array}$

$0810 \quad 1127 \quad 3.28$

$0810 \quad 1128$ 3.30

$\begin{array}{lll}0807 & 1126 & 3.32\end{array}$

$\begin{array}{lll}0803 \quad 1123 & 3.33\end{array}$

$\begin{array}{lll}0758 & 1119 & 3.35\end{array}$

$\begin{array}{lll}0753 & 1141 & 3.80\end{array}$

$\begin{array}{lll}0755 & 1141 & 3.77\end{array}$

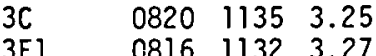

$\begin{array}{llll}3 E 2 & 0816 & 1132 & 3.27\end{array}$

$\begin{array}{llll}3 F & 0810 & 1128 & 3.30\end{array}$
Mass Deposition Rate $\left(\mu \mathrm{g} \cdot \mathrm{m}^{-2} \cdot \mathrm{hr}^{-1}\right)$

\begin{tabular}{|c|c|c|c|c|c|c|c|c|c|c|c|c|c|c|c|c|c|c|c|c|c|}
\hline \multicolumn{3}{|c|}{$\begin{array}{c}\mathrm{SO}_{4}^{--} \\
\text {Total } \\
\end{array}$} & \multicolumn{3}{|c|}{$\begin{array}{c}\mathrm{NO}_{3}^{-} \\
\text {Total Bkgd Drift } \\
\end{array}$} & \multicolumn{3}{|c|}{$\begin{array}{c}C l^{-} \\
\text {otal Bkgd Drift }\end{array}$} & \multicolumn{3}{|c|}{$\begin{array}{c}\mathrm{Na}^{+} \\
\text {Total Bkgd Drift }\end{array}$} & \multicolumn{3}{|c|}{$k^{+}$} & Total & $\mathrm{Ca}^{++}$ & Drift & Total & $\begin{array}{l}\mathrm{Mg}^{++} \\
\text {Bkgd }\end{array}$ & Drift & $\begin{array}{l}\text { Notes } \\
\text { Below }\end{array}$ \\
\hline $\begin{array}{l}58 \\
76 \\
48 \\
50\end{array}$ & & & $\begin{array}{l}51 \\
44 \\
40 \\
28\end{array}$ & & & $\begin{array}{r}75 \\
153 \\
60 \\
35\end{array}$ & & & $\begin{array}{r}37 \\
107 \\
34 \\
21\end{array}$ & & & $\begin{array}{r}8 \\
41 \\
11 \\
8\end{array}$ & & & $\begin{array}{l}37 \\
60 \\
36 \\
63\end{array}$ & & & $\begin{array}{l}5 \\
16 \\
13 \\
15\end{array}$ & . & & \\
\hline $\begin{array}{r}35 \\
278 \\
118 \\
1050 \\
1190 \\
257 \\
27\end{array}$ & $\begin{array}{l}35 \\
40 \\
41\end{array}$ & $\begin{array}{r}0 \\
128 \\
36\end{array}$ & $\begin{array}{r}32 \\
78 \\
40 \\
171 \\
143 \\
106 \\
21\end{array}$ & $\begin{array}{l}32 \\
27 \\
27\end{array}$ & $\begin{array}{l}0 \\
0.9 \\
0.3\end{array}$ & $\begin{array}{r}34 \\
123 \\
100 \\
5370 \\
4830 \\
415 \\
33\end{array}$ & $\begin{array}{l}34 \\
23 \\
46\end{array}$ & $\begin{array}{r}0 \\
100 \\
42\end{array}$ & $\begin{array}{r}29 \\
138 \\
57 \\
1370 \\
1480 \\
219 \\
26\end{array}$ & $\begin{array}{l}26 \\
26 \\
26\end{array}$ & $\begin{array}{r}3 \\
112 \\
31\end{array}$ & $\begin{array}{l}11 \\
35 \\
16 \\
44 \\
71 \\
32 \\
15\end{array}$ & $\begin{array}{l}11 \\
11 \\
11\end{array}$ & $\begin{array}{r}0 \\
24 \\
5\end{array}$ & $\begin{array}{r}17 \\
1425 \\
136 \\
\text { NA } \\
\text { NA } \\
86 \\
19\end{array}$ & $\begin{array}{l}17 \\
30 \\
30\end{array}$ & $\begin{array}{r}0 \\
20 \\
5\end{array}$ & $\begin{array}{r}5 \\
185 \\
24 \\
\text { NA } \\
\text { NA } \\
92 \\
5\end{array}$ & $\begin{array}{l}5 \\
7 \\
7\end{array}$ & $\begin{array}{r}0 \\
17 \\
5\end{array}$ & $\begin{array}{l}1 \\
2 \\
2 \\
2\end{array}$ \\
\hline $\begin{array}{r}93 \\
66 \\
153 \\
308 \\
57 \\
85 \\
30 \\
66 \\
67 \\
96 \\
41 \\
57\end{array}$ & $\begin{array}{l}41 \\
41 \\
11 \\
41 \\
11 \\
26 \\
30 \\
30 \\
41 \\
41 \\
41 \\
41\end{array}$ & $\begin{array}{r}1 \\
5 \\
142 \\
220 \\
46 \\
59 \\
0 \\
35 \\
25 \\
19 \\
0 \\
0\end{array}$ & $\begin{array}{l}53 \\
25 \\
79 \\
95 \\
31 \\
35 \\
20 \\
61 \\
51 \\
35 \\
18 \\
21\end{array}$ & $\begin{array}{l}27 \\
25 \\
27 \\
27 \\
27 \\
27 \\
20 \\
27 \\
27 \\
27 \\
18 \\
21\end{array}$ & $\begin{array}{r}<1 \\
<.1 \\
1 \\
1.6 \\
1.1 \\
0.4 \\
0 \\
0.3 \\
0.2 \\
0.1 \\
0 \\
0\end{array}$ & $\begin{array}{r}54 \\
45 \\
355 \\
440 \\
114 \\
126 \\
11 \\
79 \\
122 \\
52 \\
32 \\
63\end{array}$ & $\begin{array}{l}46 \\
40 \\
46 \\
46 \\
46 \\
46 \\
11 \\
37 \\
46 \\
36 \\
32 \\
46\end{array}$ & $\begin{array}{r}1 \\
5 \\
166 \\
259 \\
54 \\
69 \\
0 \\
42 \\
29 \\
16 \\
0 \\
<1\end{array}$ & $\begin{array}{r}19 \\
27 \\
148 \\
217 \\
63 \\
74 \\
9 \\
49 \\
40 \\
36 \\
18 \\
20\end{array}$ & $\begin{array}{r}19 \\
22 \\
23 \\
23 \\
22 \\
22 \\
9 \\
18 \\
18 \\
20 \\
18 \\
20\end{array}$ & $\begin{array}{r}0 \\
5 \\
125 \\
194 \\
41 \\
52 \\
0 \\
31 \\
22 \\
16 \\
0 \\
0\end{array}$ & $\begin{array}{r}5 \\
22 \\
6 \\
10 \\
25 \\
13 \\
4 \\
36 \\
29 \\
27 \\
27 \\
7\end{array}$ & $\begin{array}{r}5 \\
10 \\
6 \\
10 \\
10 \\
10 \\
4 \\
8 \\
8 \\
9 \\
10 \\
7\end{array}$ & $\begin{array}{r}0 \\
1 \\
0 \\
0.4 \\
11 \\
3 \\
0 \\
9 \\
6 \\
5 \\
0 \\
0\end{array}$ & $\begin{array}{r}42 \\
48 \\
\text { NA } \\
289 \\
80 \\
\text { NA } \\
24 \\
53 \\
65 \\
71 \\
26 \\
32\end{array}$ & $\begin{array}{l}30 \\
30 \\
-- \\
30 \\
30 \\
-- \\
24 \\
30 \\
30 \\
30 \\
26 \\
30\end{array}$ & $\begin{array}{r}<1 \\
0.8 \\
-- \\
33 \\
7 \\
-- \\
0 \\
5 \\
3.7 \\
2.7 \\
0 \\
0\end{array}$ & $\begin{array}{r}3 \\
9 \\
\text { NA } \\
92 \\
35 \\
\text { NA } \\
8 \\
29 \\
30 \\
5 \\
4 \\
5\end{array}$ & $\begin{array}{r}3 \\
7 \\
-- \\
7 \\
7 \\
-- \\
7 \\
7 \\
7 \\
3.6 \\
7 \\
5\end{array}$ & $\begin{array}{r}0 \\
.7 \\
-- \\
29 \\
6 \\
-- \\
0 \\
5 \\
3.2 \\
1.6 \\
0 \\
0\end{array}$ & \\
\hline $\begin{array}{l}12 \\
32 \\
41 \\
46 \\
17 \\
43 \\
15 \\
36 \\
74 \\
49 \\
32 \\
24\end{array}$ & $\begin{array}{l}12 \\
32 \\
33 \\
41 \\
17 \\
41 \\
15 \\
30 \\
32 \\
41 \\
30 \\
24\end{array}$ & $\begin{array}{r}0 \\
0 \\
8 \\
5 \\
0 \\
0 \\
0 \\
6 \\
41 \\
8 \\
2 \\
0\end{array}$ & $\begin{array}{l}15 \\
27 \\
33 \\
32 \\
16 \\
16 \\
11 \\
51 \\
30 \\
21 \\
21 \\
19\end{array}$ & $\begin{array}{l}15 \\
27 \\
27 \\
27 \\
16 \\
16 \\
11 \\
27 \\
27 \\
21 \\
21 \\
19\end{array}$ & $\begin{array}{r}0 \\
0 \\
0.1 \\
<.1 \\
0 \\
0 \\
0 \\
<.1 \\
0.3 \\
0 \\
0 \\
0\end{array}$ & $\begin{array}{r}\text { NA } \\
82 \\
57 \\
20 \\
6 \\
6 \\
5 \\
37 \\
87 \\
63 \\
45 \\
30\end{array}$ & $\begin{array}{r}-- \\
46 \\
46 \\
19 \\
6 \\
6 \\
5 \\
32 \\
38 \\
46 \\
41 \\
30\end{array}$ & $\begin{array}{r}-- \\
<1 \\
10 \\
1.2 \\
0 \\
0 \\
0 \\
5 \\
49 \\
10 \\
4 \\
0\end{array}$ & $\begin{array}{r}1 \\
13 \\
28 \\
22 \\
4 \\
10 \\
9 \\
26 \\
57 \\
28 \\
23 \\
13\end{array}$ & $\begin{array}{r}1 \\
13 \\
21 \\
21 \\
4 \\
10 \\
9 \\
21 \\
21 \\
21 \\
20 \\
13\end{array}$ & $\begin{array}{r}0 \\
0 \\
7 \\
1.5 \\
0 \\
0 \\
0 \\
5 \\
36 \\
7 \\
3 \\
0\end{array}$ & $\begin{array}{r}5 \\
7 \\
9 \\
15 \\
1 \\
39 \\
0 \\
12 \\
16 \\
14 \\
28 \\
5\end{array}$ & $\begin{array}{r}5 \\
7 \\
8.6 \\
10 \\
1 \\
11 \\
0 \\
10 \\
9 \\
11 \\
11 \\
5\end{array}$ & $\begin{array}{r}0 \\
0 \\
0.6 \\
0.4 \\
0 \\
0 \\
0 \\
1.5 \\
7 \\
2 \\
0.8 \\
0\end{array}$ & $\begin{array}{r}10 \\
24 \\
53 \\
28 \\
9 \\
16 \\
15 \\
46 \\
64 \\
46 \\
26 \\
22\end{array}$ & $\begin{array}{r}10 \\
24 \\
30 \\
28 \\
9 \\
16 \\
15 \\
30 \\
30 \\
30 \\
22 \\
22\end{array}$ & $\begin{array}{r}0 \\
0 \\
1.2 \\
0.2 \\
0 \\
0 \\
0 \\
0.9 \\
6 \\
1.2 \\
0.5 \\
0\end{array}$ & $\begin{array}{r}1 \\
7 \\
10 \\
7 \\
2 \\
6 \\
4 \\
15 \\
25 \\
20 \\
8 \\
8\end{array}$ & $\begin{array}{l}1 \\
7 \\
7 \\
7 \\
2 \\
6 \\
4 \\
7 \\
7 \\
7 \\
7 \\
7\end{array}$ & $\begin{array}{r}0 \\
0 \\
1.1 \\
0.2 \\
0 \\
0 \\
0 \\
0.8 \\
5.4 \\
1.1 \\
0.4 \\
0\end{array}$ & \\
\hline $\begin{array}{r}54 \\
53 \\
152 \\
36 \\
87 \\
66\end{array}$ & $\begin{array}{l}38 \\
41 \\
41 \\
10 \\
10 \\
41\end{array}$ & $\begin{array}{r}16 \\
10 \\
26 \\
26 \\
77 \\
0\end{array}$ & $\begin{array}{l}38 \\
50 \\
92 \\
27 \\
42 \\
19\end{array}$ & $\begin{array}{l}27 \\
27 \\
27 \\
27 \\
27 \\
19\end{array}$ & $\begin{array}{r}0.1 \\
0.1 \\
0.2 \\
0.2 \\
0.6 \\
0\end{array}$ & $\begin{array}{r}65 \\
41 \\
184 \\
74 \\
172 \\
6\end{array}$ & $\begin{array}{r}46 \\
32 \\
46 \\
43 \\
46 \\
6\end{array}$ & $\begin{array}{r}19 \\
9 \\
31 \\
31 \\
90 \\
0\end{array}$ & $\begin{array}{r}32 \\
27 \\
44 \\
44 \\
88 \\
5\end{array}$ & $\begin{array}{r}18 \\
18 \\
21 \\
21 \\
21 \\
5\end{array}$ & $\begin{array}{r}14 \\
9 \\
23 \\
23 \\
67 \\
0\end{array}$ & $\begin{array}{r}9 \\
9 \\
0 \\
28 \\
53 \\
4\end{array}$ & $\begin{array}{r}8 \\
8 \\
0 \\
11 \\
11 \\
4\end{array}$ & $\begin{array}{r}1.5 \\
1.4 \\
0 \\
6.5 \\
19 \\
0\end{array}$ & $\begin{array}{r}75 \\
39 \\
371 \\
71 \\
56 \\
18\end{array}$ & $\begin{array}{l}30 \\
30 \\
30 \\
30 \\
30 \\
18\end{array}$ & $\begin{array}{r}2.4 \\
1.4 \\
3.9 \\
3.9 \\
11 \\
0\end{array}$ & $\begin{array}{r}16 \\
56 \\
55 \\
22 \\
19 \\
3\end{array}$ & $\begin{array}{l}7 \\
7 \\
7 \\
7 \\
7 \\
3\end{array}$ & $\begin{array}{r}2.1 \\
1.3 \\
3.4 \\
3.4 \\
10 \\
0\end{array}$ & \\
\hline
\end{tabular}

'Some contamination?

¿Dust contamination 
TABLE E2.2. Drift Mineral Mass Deposition Rates, Test Run 2, 17 June 1978

Sample Interval

Sample Start Stop $\Delta t$ $\begin{array}{lll}\text { Sample Start } & \text { Stop } & \Delta t \\ \text { ID } & \text { (PDT) } & \text { (PDT) } \\ \text { (hr) }\end{array}$

$\begin{array}{llll}0 A & 0945 & 1304 & 3.32 \\ \text { ORN } & 0940 & 1223 & 2.72\end{array}$

$\begin{array}{llll}\text { OBN } & 0940 & 1223 & 2.72 \\ \text { OBS } & 0939 & 1226 & 2.78\end{array}$

$\begin{array}{llll}O C & 0935 & 1307 & 3.53\end{array}$

$\begin{array}{llll}1 C 1 & 0839 & 1300 & 4.35\end{array}$

$\begin{array}{llll}1 C 2 & 0839 & 1300 & 4.35\end{array}$

$\begin{array}{lllll}101 & 0845 & 1237 & 3.87\end{array}$

$102 \quad 0345 \quad 1237 \quad 3.87$

IE $\quad 08551242 \quad 3.78$

IF $\quad 0926 \quad 1246 \quad 3.33$

IAA $\quad 0910 \quad 1258 \quad 3.80$

$\begin{array}{llll}1 A B & 0903 & 1255 & 3.87\end{array}$

AACl $0901 \quad 1250 \quad 3.82$

IAC2 $0901 \quad 1250 \quad 3.82$

$\begin{array}{llll}\text { IADI } & 0850 & 1230 & 3.67\end{array}$

$\begin{array}{llll}1 A D 2 & 0850 & 1230 & 3.67\end{array}$

IAF $1041 \quad i 305 \quad 2.40$

$\begin{array}{lllll}2 E & 0857 & 1304 & 4.12\end{array}$

$\begin{array}{llll}2 F 1 & 0846 & 1307 & 4.35\end{array}$

$\begin{array}{llll}2 F 2 & 0846 & 1307 & 4.35\end{array}$

$2 G 1 \quad 0850 \quad 1309 \quad 4.32$

$\begin{array}{llll}2 G 2 & 0850 & 1309 & 4.32\end{array}$

$\begin{array}{llll}24 & 0853 & 1313 & 4.33\end{array}$

$\begin{array}{llll}3 A & 0915 & 1231 & 3.37 \\ 3 B & 0912 & 1232 & 3.33\end{array}$

$\begin{array}{llll}3 \mathrm{~B} & 0912 & 1232 & 3.33 \\ 3 \mathrm{C} & 0902 & 1242 & 3.67 \\ 3 E & 0906 & 1251 & 3.75\end{array}$

$\begin{array}{llll}3 C & 0902 & 1242 & 3.67 \\ 3 E & 0906 & 1251 & 3.75\end{array}$

Acid contamination,

${ }^{2}$ Acid contamination
Mass Deposition Rate $\left(\mu \mathrm{g} \cdot \mathrm{m}^{-2} \cdot h r^{-1}\right.$ )

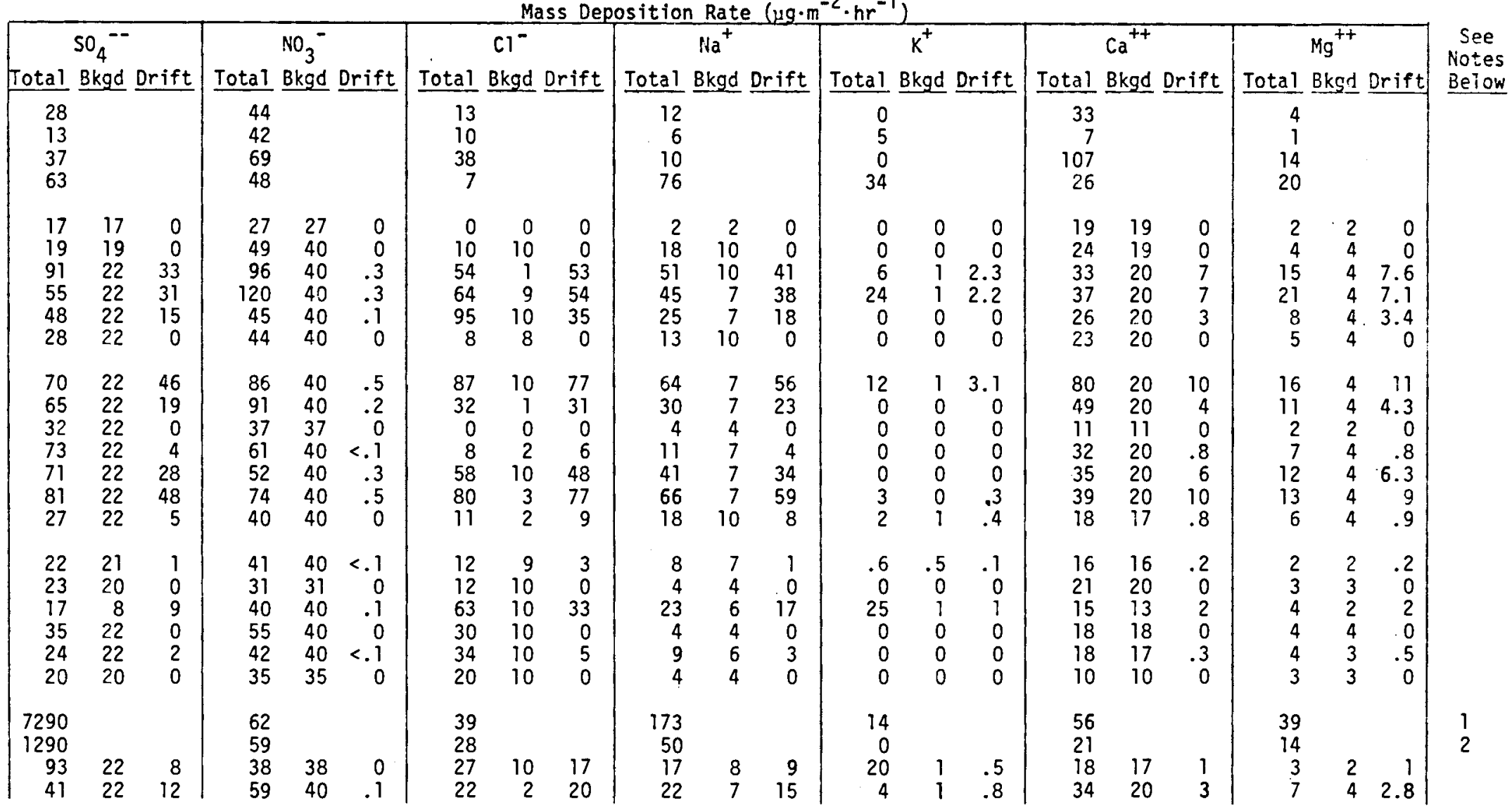


IABLE E2.3. Drift Mineral Mass Deposition Rates, Test Run 3, 15 June 1978

Sample Interval

Sample Start Stop $\Delta t$

ID (PDT) (PDT) (hr)

UUA $\frac{\text { IDA }}{1332} \frac{3035}{17.05}$ Total Bkgd Drift

\begin{tabular}{llll|r} 
IUUB & 1336 & 1534 & 1.97 & 2340
\end{tabular}

\begin{tabular}{llll|l} 
UA & 1331 & 1528 & 1.93 & 104
\end{tabular}

$\begin{array}{llll}\text { UB } & 1337 & 303516.97 & 487\end{array}$

\begin{tabular}{llll|r} 
OBS & 1252 & 1510 & 2.33 & 76 \\
OC1 & 1247 & 1440 & 1.88 & 1420 \\
OC2 & 1247 & 1440 & 1.88 & 1285 \\
OD & 1241 & 1445 & 2.07 & 143
\end{tabular}

\begin{tabular}{llll|r} 
OD & 1241 & 1445 & 2.07 & 143 \\
$O E$ & 1236 & 1450 & 2.23 & 95
\end{tabular}

\begin{tabular}{llll|ll}
$1 C$ & 1252 & 1513 & 2.35 & 95 & 20
\end{tabular}

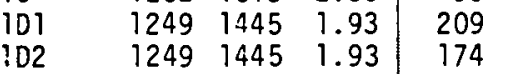

\begin{tabular}{llll|rr}
102 & 1249 & 1445 & 1.93 & 174 & 21 \\
IE. & 1244 & 1440 & 1.93 & 57 & 49
\end{tabular}

\begin{tabular}{llll|rr} 
IE & 1244 & 1440 & 1.93 & 57 & 49 \\
IFI & 1240 & 1503 & 2.38 & 1550 & 60 \\
IE2 & 1240 & 1503 & 2.38 & 506 & 60
\end{tabular}

\begin{tabular}{llll|ll} 
IG & 1251 & 1505 & 2.25 & 335 & 60 \\
II & 1230 & 1456 & 2.43 & 152 & 60
\end{tabular}

\begin{tabular}{llll|ll}
11 & 1230 & 1456 & 2.43 & 152 & 60 \\
$1 \mathrm{~J}$ & 1234 & 1456 & 2.37 & 173 & 60
\end{tabular}

\begin{tabular}{llll|r}
$2 B$ & 1300 & 1515 & 2.25 & 260 \\
$2 E$ & 1301 & 1531 & 2.50 & 44
\end{tabular}

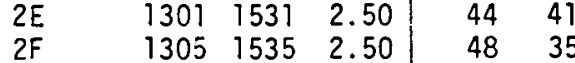

\begin{tabular}{rrrr|rr}
$2 G 1$ & 1304 & 1537 & 2.55 & 101 & 60 \\
$2 G 2$ & 1304 & 1537 & 2.55 & 32 & 28
\end{tabular}

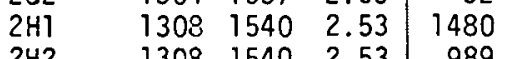

\begin{tabular}{llll|r}
$2 \mathrm{H} 2$ & 1308 & 1540 & 2.53 & 989 \\
$2 \mathrm{I}$ & 1300 & 1516 & 2.27 & 357
\end{tabular}

\begin{tabular}{llll|r}
$2 \mathrm{I}$ & 1300 & 1516 & 2.27 & 357 \\
$2 \mathrm{~J}$ & 1254 & 1510 & 2.27 & 1380 \\
$2 \mathrm{KI}$ & 1257 & 1513 & 2.27 & 8560
\end{tabular}

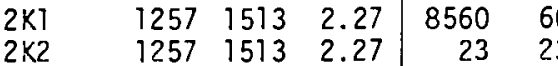

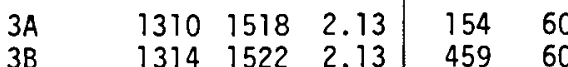

\begin{tabular}{lll|ll}
1314 & 1522 & 2.13 & 459 & 60 \\
1308 & 1527 & 2.32 & 128 & 60
\end{tabular}

\begin{tabular}{lll|ll}
1308 & 1527 & 2.32 & 128 & 60 \\
1308 & 1527 & 2.32 & 618 & 60
\end{tabular}

\begin{tabular}{lll|ll}
1305 & 1524 & 2.32 & 150 & 57
\end{tabular}

\begin{tabular}{rrr|r}
1305 & 1524 & 2.32 & 886 \\
1302 & 1510 & 2.13 & 2050
\end{tabular}

$3 \mathrm{~F}$

On ground, picked up 6-16

${ }^{2} T$ on ground

${ }^{3}$ Road traffic dust contamination

14
303
1420
1285

74 209
On ground at end

$\left.{ }^{6}\right]$ on ground at end

Mass Deposition Rate $\left(\mu \mathrm{g} \cdot \mathrm{m}^{-2} \cdot \mathrm{hr}^{-1}\right)$

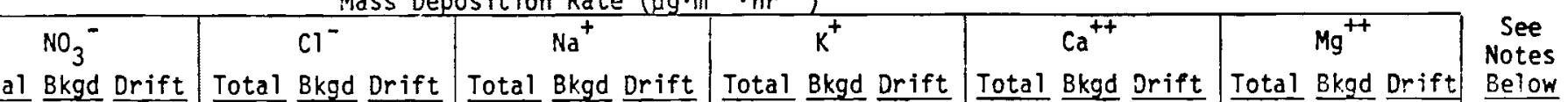
Total Bkgd Drift Total Bkgd Drift Total Bkgd Drift Total Bkgd Drift Total Bkgd Orift Total Bk.gd Drift Betow 146

\begin{tabular}{rlr|rrr|rrr}
65 & 65 & 0 & 77 & 46 & 20 & 43 & 26 & 17 \\
359 & 80 & 6 & 1050 & 46 & 435 & 343 & 26 & 317 \\
408 & 80 & 36 & 6470 & 46 & 2820 & 2070 & 26 & 2030
\end{tabular} \begin{tabular}{lll|lll|lll|}
348 & 80 & 35 & 6140 & 46 & 2760 & 2370 & 26 & 1990
\end{tabular}

\begin{tabular}{l|lll|lll|lll|}
76 & 90 & 80 & 1.4 & 204 & 46 & 110 & 111 & 26 & 85
\end{tabular}

\begin{tabular}{r|} 
\\
\\
\\
\\
17 \\
317 \\
2030 \\
1990 \\
85 \\
9 \\
79 \\
230 \\
160 \\
20 \\
610 \\
230 \\
64 \\
38 \\
64 \\
\hline 106 \\
5 \\
14 \\
42 \\
5 \\
219 \\
241 \\
294 \\
420 \\
690 \\
0 \\
29 \\
77 \\
78 \\
4 \\
98 \\
169 \\
42 \\
\hline
\end{tabular}

$\begin{array}{rl}54 & \\ 70 & \\ 33 & \\ 141 & \\ 2 & 2 \\ 18 & 5 \\ 58 & 6 \\ 70 & 6 \\ 5 & 5 \\ 5 & 5 \\ & \\ 5 & 5 \\ 27 & 6 \\ 33 & 6 \\ 0 & 0 \\ 72 & 5 \\ 41 & 5 \\ 18 & 5 \\ 7 & 5 \\ 29 & 8 \\ & \\ 8 & 5 \\ 0 & 0 \\ 0 & 0 \\ 0 & 0 \\ 0 & 0 \\ 29 & 4 \\ 18 & 4 \\ 11 & 5 \\ 33 & 5 \\ 60 & 5 \\ 10 & 8 \\ & \\ 6 & 5 \\ 19 & 5 \\ 20 & 5 \\ 8 & 7 \\ 1 & 1 \\ 13 & 5 \\ 34 & 8 \\ \end{array}$

${ }^{7}$ Dust contamination

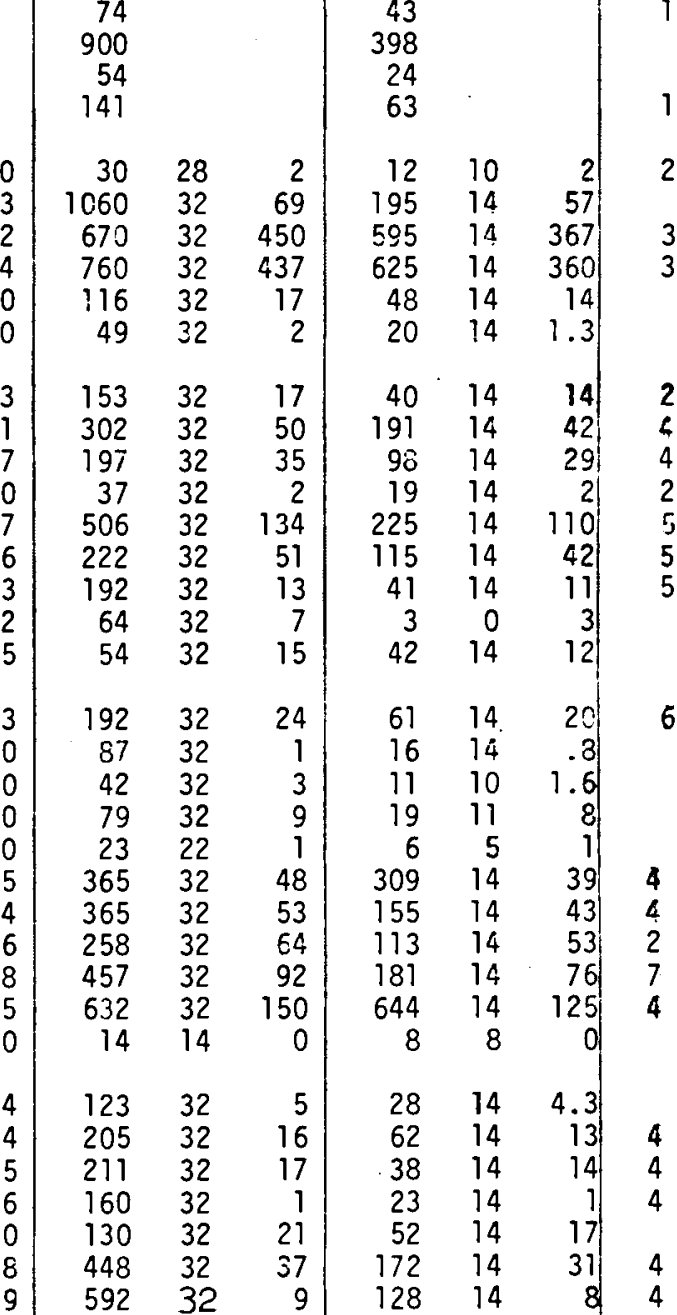


TABLE E2.4. Drift Mineral Mass Deposition Rates, Test Run 4, 21 June 1978

Sample Interval

Mass Deposition Rate $\left(\mu \mathrm{g} \cdot \mathrm{m}^{-2} \cdot \mathrm{hr}^{-1}\right)$

\begin{tabular}{|c|c|c|c|c|c|c|c|c|c|c|c|c|c|c|c|c|c|c|c|c|c|c|c|c|c|}
\hline $\begin{array}{c}\text { Sample } \\
\text { ID } \\
\end{array}$ & $\begin{array}{l}\text { Start } \\
\text { (PDT) }\end{array}$ & $\begin{array}{l}\text { Stop } \\
\text { (PDI) }\end{array}$ & $\begin{array}{c}\Delta t \\
(h r) \\
\end{array}$ & Total & $\begin{array}{l}\mathrm{SO}_{4}{ }^{--} \\
\text {Bkgd }\end{array}$ & & Total & $\begin{array}{l}\mathrm{O}_{3}^{-} \\
\mathrm{kgd}\end{array}$ & Drift & Total & $\begin{array}{l}\mathrm{Cl}^{-} \\
\text {Bkgd }\end{array}$ & Drift & Total & $\begin{array}{l}\mathrm{Na}^{+} \\
\text {Bkgd } \\
\end{array}$ & rift & Total & $\mathrm{kgd}$ & $\underline{\text { Drift }}$ & Tota? & $3 \mathrm{kgd}$ & Drift & Total & $\begin{array}{l}\mathrm{Mg}^{++} \\
\text {Bkgd }\end{array}$ & Drift & $\begin{array}{l}\text { See } \\
\text { Notes } \\
\text { Below }\end{array}$ \\
\hline $\begin{array}{l}\text { UUAंI } \\
\text { UUA2 } \\
\text { UUB } \\
\text { UA } \\
\text { UB }\end{array}$ & $\begin{array}{l}0538 \\
0638 \\
0544 \\
0633 \\
0646\end{array}$ & $\begin{array}{l}1642 \\
1642 \\
1649 \\
1638 \\
1654\end{array}$ & $\begin{array}{l}10.07 \\
10.07 \\
10.08 \\
10.08 \\
10.13\end{array}$ & $\begin{array}{r}288 \\
361 \\
51 \\
114 \\
108\end{array}$ & & & $\begin{array}{l}177 \\
194 \\
244 \\
177 \\
137\end{array}$ & & & $\begin{array}{r}408 \\
549 \\
576 \\
256 \\
99\end{array}$ & & & $\begin{array}{r}325 \\
275 \\
448 \\
218 \\
89\end{array}$ & & & $\begin{array}{r}10 \\
9 \\
12 \\
3 \\
3\end{array}$ & & & $\begin{array}{r}131 \\
159 \\
187 \\
75 \\
52\end{array}$ & & & $\begin{array}{l}65 \\
78 \\
83 \\
45 \\
28\end{array}$ & & & $\begin{array}{l}1 \\
1 \\
1 \\
1 \\
1\end{array}$ \\
\hline $\begin{array}{l}\text { OAI } \\
\text { OA.2 } \\
\text { OBN } \\
\text { GBS } \\
O C\end{array}$ & $\begin{array}{l}0840 \\
0340 \\
0905 \\
0858 \\
0942\end{array}$ & $\begin{array}{l}1248 \\
1248 \\
1219 \\
1223 \\
1316\end{array}$ & $\begin{array}{l}4.13 \\
4.13 \\
3.23 \\
3.50 \\
3.57\end{array}$ & $\begin{array}{r}81 \\
62 \\
233 \\
60 \\
370\end{array}$ & $\begin{array}{r}9 \\
0 \\
40 \\
37 \\
40\end{array}$ & $\begin{array}{r}72 \\
62 \\
75 \\
23 \\
5.4\end{array}$ & $\begin{array}{r}83 \\
57 \\
112 \\
35 \\
215\end{array}$ & $\begin{array}{l}50 \\
50 \\
50 \\
35 \\
50\end{array}$ & $\begin{array}{r}.6 \\
.5 \\
.6 \\
0 \\
<.1\end{array}$ & $\begin{array}{l}202 \\
174 \\
345 \\
122 \\
947\end{array}$ & $\begin{array}{r}0 \\
0 \\
33 \\
31 \\
33\end{array}$ & $\begin{array}{r}202 \\
174 \\
312 \\
91 \\
23\end{array}$ & $\begin{array}{r}164 \\
205 \\
174 \\
71 \\
35\end{array}$ & $\begin{array}{l}22 \\
27 \\
26 \\
24 \\
24\end{array}$ & $\begin{array}{r}142 \\
123 \\
148 \\
47 \\
11\end{array}$ & $\begin{array}{r}13 \\
8 \\
11 \\
7 \\
27\end{array}$ & $\begin{array}{l}2 \\
2 \\
2 \\
2 \\
2\end{array}$ & $\begin{array}{r}6 \\
5 \\
6 \\
2 \\
.5\end{array}$ & $\begin{array}{r}36 \\
31 \\
5 i 3 \\
41 \\
164\end{array}$ & $\begin{array}{l}23 \\
20 \\
25 \\
25 \\
25\end{array}$ & $\begin{array}{r}13 \\
11 \\
14 \\
4 \\
1.0\end{array}$ & $\begin{array}{r}24 \\
23 \\
71 \\
17 \\
172\end{array}$ & $\begin{array}{l}7 \\
5 \\
8 \\
8 \\
8\end{array}$ & $\begin{array}{r}17 \\
18 \\
21 \\
7 \\
1.5\end{array}$ & 1 \\
\hline $\begin{array}{l}1 Z 2 \\
1 Z 1 \\
1 Z 2 \\
1 Y 1 \\
1 Y 2 \\
1 A 1 \\
1 A 2 \\
1 B 1 \\
182 \\
1 C\end{array}$ & $\begin{array}{l}1136 \\
1017 \\
1017 \\
0341 \\
0841 \\
0847 \\
0847 \\
0855 \\
0855 \\
0859\end{array}$ & $\begin{array}{l}1253 \\
1259 \\
1259 \\
1247 \\
1247 \\
1254 \\
1254 \\
1259 \\
1259 \\
1302\end{array}$ & $\begin{array}{l}1.28 \\
2.70 \\
2.70 \\
4.12 \\
4.12 \\
4.12 \\
4.12 \\
4.07 \\
4.07 \\
4.05\end{array}$ & $\begin{array}{r}631 \\
39 \\
43 \\
57 \\
68 \\
106 \\
54 \\
77 \\
\text { NA } \\
214\end{array}$ & $\begin{array}{l}40 \\
39 \\
39 \\
40 \\
40 \\
40 \\
40 \\
18 \\
-10\end{array}$ & $\begin{array}{r}120 \\
0 \\
0 \\
5 \\
15 \\
12 \\
6 \\
59 \\
-- \\
95\end{array}$ & $\begin{array}{r}167 \\
57 \\
50 \\
61 \\
66 \\
70 \\
53 \\
71 \\
\text { NA } \\
190\end{array}$ & $\begin{array}{l}50 \\
50 \\
50 \\
50 \\
50 \\
50 \\
50 \\
50 \\
-- \\
50\end{array}$ & $\begin{array}{r}1 \\
0 \\
0 \\
<.1 \\
.1 \\
.1 \\
<.1 \\
.5 \\
-.8 \\
.8\end{array}$ & $\begin{array}{r}870 \\
41 \\
29 \\
50 \\
74 \\
67 \\
57 \\
247 \\
\text { NA } \\
443\end{array}$ & $\begin{array}{l}33 \\
33 \\
29 \\
25 \\
27 \\
27 \\
33 \\
27 \\
-- \\
33\end{array}$ & $\begin{array}{r}510 \\
0 \\
0 \\
25 \\
47 \\
40 \\
24 \\
220 \\
-- \\
400\end{array}$ & $\begin{array}{r}268 \\
31 \\
33 \\
33 \\
51 \\
44 \\
32 \\
139 \\
41 \\
209\end{array}$ & $\begin{array}{l}27 \\
27 \\
27 \\
21 \\
21 \\
21 \\
21 \\
21 \\
21 \\
21\end{array}$ & $\begin{array}{r}240 \\
0 \\
0 \\
12 \\
30 \\
23 \\
11 \\
118 \\
20 \\
188\end{array}$ & $\begin{array}{r}23 \\
2 \\
0 \\
2 \\
3 \\
1 \\
0 \\
3 \\
2 \\
18\end{array}$ & $\begin{array}{l}2 \\
2 \\
0 \\
1 \\
2 \\
1 \\
0 \\
1 \\
1 \\
2\end{array}$ & $\begin{array}{r}9 \\
0 \\
0 \\
.5 \\
1.3 \\
0 \\
0 \\
2.3 \\
.9 \\
8\end{array}$ & $\begin{array}{r}544 \\
39 \\
24 \\
54 \\
52 \\
45 \\
41 \\
72 \\
\text { NA } \\
172\end{array}$ & $\begin{array}{l}25 \\
25 \\
24 \\
25 \\
25 \\
25 \\
25 \\
25 \\
-- \\
25\end{array}$ & $\begin{array}{r}22 \\
0 \\
0 \\
1.1 \\
2.7 \\
2.1 \\
1.0 \\
11 \\
-17\end{array}$ & $\begin{array}{r}187 \\
11 \\
7 \\
17 \\
17 \\
18 \\
14 \\
\text { NA } \\
\text { NA } \\
73\end{array}$ & $\begin{array}{r}8 \\
8 \\
7 \\
8 \\
8 \\
8 \\
8 \\
-- \\
--\end{array}$ & $\begin{array}{r}35 \\
0 \\
0 \\
1.7 \\
4 \\
3.3 \\
1.6 \\
--. \\
-. \\
37\end{array}$ & 2 \\
\hline $\begin{array}{l}1 A Z 1 \\
1 A Z 2 \\
1 A A \\
1 A B 1 \\
1 A B 2 \\
1 A C\end{array}$ & $\begin{array}{l}0838 \\
0838 \\
0847 \\
0852 \\
0852 \\
0859\end{array}$ & $\begin{array}{l}1249 \\
1249 \\
1254 \\
1257 \\
1257 \\
1301\end{array}$ & $\begin{array}{l}4.18 \\
4.18 \\
4.12 \\
4.08 \\
4.08 \\
4.03\end{array}$ & $\begin{array}{r}75 \\
84 \\
169 \\
92 \\
171 \\
61\end{array}$ & $\begin{array}{l}37 \\
40 \\
40 \\
40 \\
40 \\
40\end{array}$ & $\begin{array}{r}38 \\
22 \\
6 \\
.5 \\
66 \\
17\end{array}$ & $\begin{array}{r}85 \\
65 \\
126 \\
98 \\
119 \\
73\end{array}$ & $\begin{array}{l}50 \\
50 \\
50 \\
50 \\
50 \\
50\end{array}$ & $\begin{array}{r}.3 \\
.2 \\
<.1 \\
0 \\
.6 \\
.1\end{array}$ & $\begin{array}{r}226 \\
186 \\
422 \\
163 \\
273 \\
85\end{array}$ & $\begin{array}{l}33 \\
33 \\
33 \\
33 \\
27 \\
27\end{array}$ & $\begin{array}{r}160 \\
94 \\
26 \\
2 \\
247 \\
58\end{array}$ & $\begin{array}{r}96 \\
65 \\
12 \\
1 \\
152 \\
54\end{array}$ & $\begin{array}{r}21 \\
21 \\
0 \\
0 \\
21 \\
21\end{array}$ & $\begin{array}{r}75 \\
44 \\
12 \\
1 \\
131 \\
33\end{array}$ & $\begin{array}{r}6 \\
11 \\
9 \\
3 \\
28 \\
3\end{array}$ & $\begin{array}{l}2 \\
2 \\
2 \\
2\end{array}$ & $\begin{array}{r}3.3 \\
1.9 \\
.5 \\
.2 \\
6 \\
1.4\end{array}$ & $\begin{array}{r}105 \\
94 \\
224 \\
88 \\
129 \\
48\end{array}$ & $\begin{array}{l}25 \\
25 \\
25 \\
25 \\
25 \\
25\end{array}$ & $\begin{array}{r}7 \\
4 \\
1.1 \\
.1 \\
12 \\
3\end{array}$ & $\begin{array}{l}38 \\
30 \\
76 \\
37 \\
50 \\
22\end{array}$ & $\begin{array}{l}8 \\
8 \\
8 \\
8 \\
8 \\
8\end{array}$ & $\begin{array}{r}11 \\
6 \\
1.7 \\
.2 \\
19 \\
5\end{array}$ & 1 \\
\hline $\begin{array}{l}2 A 1 \\
2 A 2 \\
2 B\end{array}$ & $\begin{array}{l}0907 \\
0907 \\
0913\end{array}$ & $\begin{array}{l}1306 \\
1306 \\
1306\end{array}$ & $\begin{array}{l}3.98 \\
3.98 \\
3.88\end{array}$ & $\begin{array}{r}40 \\
39 \\
194\end{array}$ & $\begin{array}{l}40 \\
39 \\
40\end{array}$ & $\begin{array}{r}0 \\
0 \\
48\end{array}$ & $\begin{array}{l}47 \\
40 \\
78\end{array}$ & $\begin{array}{l}47 \\
40 \\
50\end{array}$ & $\begin{array}{r}0 \\
0 \\
.4\end{array}$ & $\begin{array}{r}26 \\
36 \\
157\end{array}$ & $\begin{array}{l}26 \\
33 \\
23\end{array}$ & $\begin{array}{r}0 \\
0 \\
134\end{array}$ & $\begin{array}{r}24 \\
18 \\
116\end{array}$ & $\begin{array}{l}24 \\
18 \\
27\end{array}$ & $\begin{array}{r}0 \\
0 \\
89\end{array}$ & $\begin{array}{l}4 \\
0 \\
8\end{array}$ & 2 & $\begin{array}{l}0 \\
0 \\
4\end{array}$ & $\begin{array}{r}21 \\
16 \\
104\end{array}$ & $\begin{array}{l}21 \\
16 \\
25\end{array}$ & $\begin{array}{l}0 \\
0 \\
9\end{array}$ & $\begin{array}{r}8 \\
7 \\
34\end{array}$ & $\begin{array}{l}8 \\
7 \\
8\end{array}$ & $\begin{array}{r}0 \\
0 \\
14\end{array}$ & 3 \\
\hline
\end{tabular}

TSand

${ }^{2}$ Sand, insect

${ }^{3}$ Spider 
TABLE E2.5. Drift Minera1 Mass Deposition Rates, Test Run 5, 18 June 1978

Sample Interval

Mass Deposition Rate $\left(\mu \mathrm{g} \cdot \mathrm{m}^{-2} \cdot \mathrm{hr}^{-1}\right)$

Sample Start Stop $\Delta t$ $\frac{10}{\text { IDOT) }} \frac{\text { (PDT) }}{\text { (hr) }}$ OAl $0816 \quad 1220 \quad 4.07$

OA2 $\quad 0816 \quad 1220 \quad 4.07$

$\begin{array}{lllll}0 C 1 & 0811 & 1224 & 4.22\end{array}$

OC2 $0811 \quad 1224 \quad 4.22$

$121 \quad 0844 \quad 1232 \quad 3.80$

$122 \quad 0644 \quad 1232 \quad 3.80$

$\begin{array}{llll}1 Y & 0842 & 1216 & 3.57\end{array}$

$\begin{array}{llll}1 . A 1 & 0339 & 1208 & 3.48\end{array}$

$\begin{array}{llll}1 A 2 & 0839 & 1208 & 3.48\end{array}$

$\begin{array}{lllll}1 \mathrm{~B} & 0834 & 1214 & 3.67\end{array}$

Cl $\quad 0958 \quad 1210 \quad 2.20$

$\begin{array}{llll}1 A Z & 0828 & 1223 & 3.92\end{array}$

$\begin{array}{llll}\text { IAAl } & 0835 & 1221 & 3.77\end{array}$

$\begin{array}{llll}1 A A 2 & 0835 & 1221 & 3.77\end{array}$

$\begin{array}{llll}\text { IAB } & 0929 & 1205 & 2.60\end{array}$

$\begin{array}{llll}1 A C & 1143 & 1235 & 0.87\end{array}$

$\begin{array}{llll}2 A & 0827 & 1226 & 3.98\end{array}$

$\begin{array}{llll}2 B 7 & 0831 & 1228 & 3.95\end{array}$

$\begin{array}{llll}2 B 2 & 0831 & 1228 & 3.95\end{array}$

UUA * $0843 \quad 1416 \quad 5.55$

$\begin{array}{lllll}\text { UUA2* } & 0843 & 1416 & 5.55\end{array}$

\begin{tabular}{lllll|l} 
UUB $^{*}$ & 0855 & 1421 & 5.43 & 108
\end{tabular}

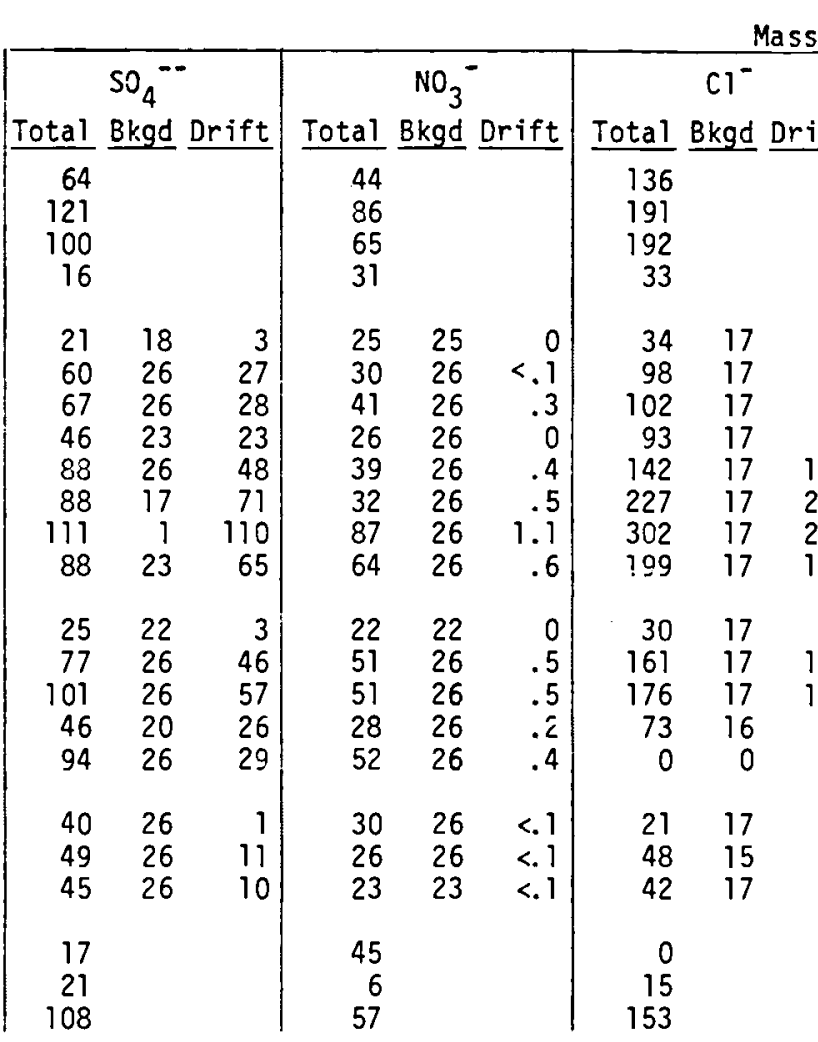

\begin{tabular}{c|c|}
$\mathrm{Na}^{+}$ & $\mathrm{K}^{+}$ \\
Total Bkgd Drift & Total Bkgd Drift \\
\hline
\end{tabular}

$\mid \begin{gathered}\mathrm{Ca}^{++} \\ \text {Total Bkgd Drift }\end{gathered}$

$24 \quad 20$

94

\begin{tabular}{r|r}
122 & 4 \\
99 & 7 \\
25 & 0
\end{tabular}

*Background sample taken 19 June 1978

1 Sand

${ }^{2}$ Lint 
TABLE E2.6. Drift Mineral Mass Deposition Rates, Test Run 6, 22 June 1978

Sample Interva

\begin{tabular}{|c|c|c|c|c|c|c|c|c|c|c|c|c|c|c|c|c|c|c|c|c|c|c|c|c|c|}
\hline $\begin{array}{c}\text { Sample } \\
\text { ID } \\
\end{array}$ & $\begin{array}{l}\text { Start } \\
\text { (FOT) }\end{array}$ & $\begin{array}{l}\text { Stop } \\
\text { (PDT) }\end{array}$ & $\begin{array}{c}\Delta t \\
\langle h r\rangle\end{array}$ & \multicolumn{3}{|c|}{$\begin{array}{l}\mathrm{SO}_{4}^{--} \\
\text {Bkgd Drift }\end{array}$} & Total & $\begin{array}{l}\mathrm{NO}_{3}^{-} \\
\mathrm{Bkgd}\end{array}$ & Drift & Total & $\begin{array}{l}\mathrm{Cl}^{-} \\
\text {Bkgd }\end{array}$ & Drift & Total & $\begin{array}{l}\mathrm{Na}^{+} \\
\mathrm{Bkgd}\end{array}$ & Drift & Total & $\begin{array}{c}\mathrm{K}^{+} \\
\text {Bkgd }\end{array}$ & Drift & Total & $\begin{array}{l}\mathrm{Ca}^{++} \\
\mathrm{Bkgd}\end{array}$ & Drift & Total & $\begin{array}{l}\mathrm{Mg}^{++} \\
8 \mathrm{kgd}\end{array}$ & Drift & $\begin{array}{c}\text { See } \\
\text { Notes } \\
\text { Eeiow }\end{array}$ \\
\hline $\begin{array}{l}\text { UUAT } \\
\text { UUA2 } \\
\text { UA } \\
\text { UB }\end{array}$ & $\begin{array}{l}0652 \\
0552 \\
0646 \\
0700\end{array}$ & $\begin{array}{l}1431 \\
1431 \\
1429 \\
1437\end{array}$ & $\begin{array}{l}7.65 \\
7.65 \\
7.72 \\
7.62\end{array}$ & $\begin{array}{r}486 \\
431 \\
186 \\
77\end{array}$ & & & $\begin{array}{r}178 \\
174 \\
173 \\
54\end{array}$ & & & $\begin{array}{l}870 \\
722 \\
503 \\
147\end{array}$ & & & $\begin{array}{r}317 \\
273 \\
263 \\
74\end{array}$ & & & $\begin{array}{r}11 \\
6 \\
1 \\
11\end{array}$ & & & $\begin{array}{r}195 \\
172 \\
112 \\
41\end{array}$ & & & $\begin{array}{l}95 \\
80 \\
50 \\
26\end{array}$ & & & $\begin{array}{l}1 \\
1 \\
1\end{array}$ \\
\hline $\begin{array}{l}\text { OA1 } \\
\text { OA2 } \\
\text { OBN1 } \\
\text { OSN2 } \\
\text { OSS } \\
\text { OE }\end{array}$ & $\begin{array}{l}0816 \\
0816 \\
0309 \\
0809 \\
0804 \\
0858\end{array}$ & $\begin{array}{l}1145 \\
1145 \\
i 155 \\
1155 \\
1200 \\
1220\end{array}$ & $\begin{array}{l}3.48 \\
3.48 \\
3.77 \\
3.77 \\
3.93 \\
3.37\end{array}$ & $\begin{array}{r}63 \\
65 \\
103 \\
86 \\
58 \\
123\end{array}$ & $\begin{array}{l}43 \\
40 \\
41 \\
45 \\
55 \\
71\end{array}$ & $\begin{array}{r}20 \\
25 \\
62 \\
41 \\
3 \\
3\end{array}$ & $\begin{array}{r}38 \\
49 \\
51 \\
36 \\
39 \\
102\end{array}$ & $\begin{array}{l}38 \\
48 \\
47 \\
36 \\
39 \\
47\end{array}$ & $\begin{array}{r}<.1 \\
.2 \\
.3 \\
<.1 \\
0 \\
<.1\end{array}$ & $\begin{array}{l}268 \\
284 \\
401 \\
326 \\
110 \\
197\end{array}$ & $\begin{array}{r}121 \\
132 \\
124 \\
124 \\
94 \\
132\end{array}$ & $\begin{array}{r}147 \\
152 \\
277 \\
202 \\
16 \\
25\end{array}$ & $\begin{array}{r}168 \\
192 \\
255 \\
195 \\
61 \\
92\end{array}$ & $\begin{array}{l}79 \\
79 \\
79 \\
79 \\
48 \\
79\end{array}$ & $\begin{array}{r}89 \\
113 \\
176 \\
116 \\
13 \\
13\end{array}$ & $\begin{array}{r}16 \\
24 \\
24 \\
15 \\
4 \\
1\end{array}$ & $\begin{array}{l}8 \\
8 \\
8 \\
8 \\
4 \\
1\end{array}$ & $\begin{array}{r}2.5 \\
3.2 \\
5 \\
3.3 \\
<.1 \\
0\end{array}$ & $\begin{array}{r}30 \\
20 \\
100 \\
70 \\
42 \\
50\end{array}$ & $\begin{array}{l}26 \\
15 \\
57 \\
57 \\
41 \\
49\end{array}$ & $\begin{array}{r}4 \\
5 \\
12 \\
8 \\
.6 \\
.3\end{array}$ & $\begin{array}{l}25 \\
21 \\
44 \\
34 \\
21 \\
38\end{array}$ & $\begin{array}{l}19 \\
13 \\
21 \\
21 \\
19 \\
21\end{array}$ & $\begin{array}{r}6 \\
9 \\
19 \\
13 \\
1.4 \\
.5\end{array}$ & \\
\hline $\begin{array}{l}1 Z \\
\text { IY1 } \\
1 Y 2 \\
1 A 1 \\
1 A 2 \\
13 \\
1 C 1 \\
1 C 2\end{array}$ & $\begin{array}{l}0829 \\
0500 \\
0805 \\
0805 \\
0809 \\
0809 \\
0813 \\
0815 \\
0815\end{array}$ & $\begin{array}{l}1205 \\
1149 \\
1154 \\
1154 \\
1200 \\
1200 \\
1205 \\
1209 \\
1209\end{array}$ & $\begin{array}{l}3.60 \\
3.32 \\
3.82 \\
3.82 \\
3.85 \\
3.85 \\
3.87 \\
3.90 \\
3.90\end{array}$ & $\begin{array}{r}147 \\
58 \\
118 \\
125 \\
94 \\
119 \\
195 \\
208 \\
186\end{array}$ & $\begin{array}{l}71 \\
58 \\
71 \\
71 \\
54 \\
59 \\
71 \\
71 \\
71\end{array}$ & $\begin{array}{r}30 \\
0 \\
35 \\
35 \\
40 \\
60 \\
96 \\
49 \\
80\end{array}$ & $\begin{array}{r}62 \\
44 \\
64 \\
72 \\
38 \\
69 \\
50 \\
114 \\
109\end{array}$ & $\begin{array}{l}47 \\
44 \\
47 \\
47 \\
38 \\
47 \\
47 \\
47 \\
47\end{array}$ & $\begin{array}{l}.2 \\
0 \\
.2 \\
.2 \\
.2 \\
.3 \\
.5 \\
.3 \\
.4\end{array}$ & $\begin{array}{l}389 \\
144 \\
307 \\
307 \\
305 \\
349 \\
566 \\
417 \\
475\end{array}$ & $\begin{array}{l}132 \\
132 \\
132 \\
132 \\
122 \\
122 \\
121 \\
132 \\
120\end{array}$ & $\begin{array}{r}135 \\
0 \\
175 \\
175 \\
183 \\
227 \\
445 \\
248 \\
355\end{array}$ & $\begin{array}{r}157 \\
86 \\
177 \\
177 \\
190 \\
249 \\
350 \\
217 \\
304\end{array}$ & $\begin{array}{l}79 \\
79 \\
77 \\
77 \\
77 \\
77 \\
77 \\
76 \\
76\end{array}$ & $\begin{array}{r}78 \\
0 \\
100 \\
100 \\
113 \\
172 \\
273 \\
141 \\
228\end{array}$ & $\begin{array}{r}19 \\
9 \\
8 \\
9 \\
2 \\
12 \\
11 \\
12 \\
92\end{array}$ & $\begin{array}{l}8 \\
8 \\
6 \\
6 \\
2 \\
7 \\
6 \\
8 \\
8\end{array}$ & $\begin{array}{r}2.2 \\
0 \\
2.0 \\
3.0 \\
0 \\
5 \\
5 \\
4 \\
7\end{array}$ & $\begin{array}{r}118 \\
60 \\
97 \\
97 \\
58 \\
73 \\
116 \\
133 \\
135\end{array}$ & $\begin{array}{l}57 \\
57 \\
57 \\
57 \\
53 \\
57 \\
57 \\
57 \\
57\end{array}$ & $\begin{array}{r}5 \\
0 \\
7 \\
7 \\
5 \\
11 \\
18 \\
9 \\
15\end{array}$ & $\begin{array}{l}52 \\
23 \\
39 \\
36 \\
30 \\
39 \\
65 \\
67 \\
75\end{array}$ & $\begin{array}{l}21 \\
21 \\
21 \\
21 \\
20 \\
20 \\
21 \\
21 \\
21\end{array}$ & $\begin{array}{l}8 \\
0 \\
11 \\
11 \\
10 \\
19 \\
30 \\
15 \\
25\end{array}$ & $\begin{array}{l}? \\
1\end{array}$ \\
\hline $\begin{array}{l}\text { IAZ2 } \\
\text { IAA1 } \\
\text { IAA2 } \\
\text { IAB } \\
\text { IAC1 } \\
\text { IAC2 }\end{array}$ & $\begin{array}{l}0811 \\
0817 \\
0806 \\
0806 \\
0304 \\
0758 \\
0758\end{array}$ & $\begin{array}{l}1146 \\
1146 \\
1151 \\
1151 \\
1155 \\
1158 \\
1158\end{array}$ & $\begin{array}{l}3.58 \\
3.58 \\
3.77 \\
3.77 \\
3.85 \\
4.00 \\
4.00\end{array}$ & $\begin{array}{r}98 \\
128 \\
171 \\
201 \\
137 \\
84 \\
61\end{array}$ & $\begin{array}{l}71 \\
71 \\
71 \\
71 \\
71 \\
65 \\
61\end{array}$ & $\begin{array}{l}27 \\
38 \\
94 \\
94 \\
30 \\
19 \\
.2\end{array}$ & $\begin{array}{l}47 \\
57 \\
62 \\
66 \\
69 \\
66 \\
39\end{array}$ & $\begin{array}{l}47 \\
47 \\
47 \\
47 \\
47 \\
47 \\
39\end{array}$ & $\begin{array}{r}.2 \\
.2 \\
.5 \\
.5 \\
.2 \\
.1 \\
0\end{array}$ & $\begin{array}{l}264 \\
343 \\
524 \\
614 \\
305 \\
208 \\
124\end{array}$ & $\begin{array}{l}132 \\
132 \\
125 \\
132 \\
132 \\
115 \\
122\end{array}$ & $\begin{array}{r}131 \\
197 \\
399 \\
469 \\
148 \\
93 \\
1.2\end{array}$ & $\begin{array}{r}157 \\
189 \\
346 \\
346 \\
161 \\
127 \\
75\end{array}$ & $\begin{array}{l}79 \\
79 \\
79 \\
79 \\
77 \\
74 \\
74\end{array}$ & $\begin{array}{r}78 \\
110 \\
267 \\
267 \\
84 \\
53 \\
.7\end{array}$ & $\begin{array}{r}4 \\
21 \\
23 \\
71 \\
25 \\
19 \\
7\end{array}$ & $\begin{array}{l}4 \\
8 \\
8 \\
8 \\
8 \\
8 \\
7\end{array}$ & $\begin{array}{r}0 \\
3.1 \\
8 \\
8 \\
2.5 \\
1.5 \\
<.1\end{array}$ & $\begin{array}{r}116 \\
135 \\
186 \\
186 \\
117 \\
66 \\
47\end{array}$ & $\begin{array}{l}57 \\
57 \\
57 \\
57 \\
57 \\
57 \\
47\end{array}$ & $\begin{array}{r}5 \\
7 \\
18 \\
18 \\
5.5 \\
3.5 \\
<.1\end{array}$ & $\begin{array}{l}37 \\
46 \\
64 \\
64 \\
48 \\
32 \\
25\end{array}$ & $\begin{array}{l}21 \\
21 \\
21 \\
21 \\
21 \\
21 \\
21\end{array}$ & $\begin{array}{r}8 \\
11 \\
29 \\
29 \\
9 \\
6 \\
.7\end{array}$ & $\begin{array}{l}1 \\
1 \\
1 \\
1\end{array}$ \\
\hline $\begin{array}{l}2 \mathrm{~A} 1 \\
2 \mathrm{~A} 2 \\
2 \mathrm{~B} 1 \\
2 \mathrm{~B} 2\end{array}$ & $\begin{array}{l}0817 \\
0817 \\
0827 \\
0821\end{array}$ & $\begin{array}{l}1204 \\
1204 \\
1207 \\
1207\end{array}$ & $\begin{array}{l}3.78 \\
3.78 \\
3.77 \\
3.77\end{array}$ & $\begin{array}{l}71 \\
74 \\
97 \\
81\end{array}$ & $\begin{array}{l}71 \\
71 \\
61 \\
71\end{array}$ & $\begin{array}{r}0 \\
0 \\
36 \\
10\end{array}$ & $\begin{array}{l}49 \\
51 \\
72 \\
40\end{array}$ & $\begin{array}{l}47 \\
47 \\
47 \\
40\end{array}$ & $\begin{array}{r}0 \\
0 \\
.2 \\
<.1\end{array}$ & $\begin{array}{l}116 \\
103 \\
236 \\
165\end{array}$ & $\begin{array}{l}116 \\
103 \\
118 \\
130\end{array}$ & $\begin{array}{r}0 \\
0 \\
118 \\
35\end{array}$ & $\begin{array}{r}77 \\
67 \\
180 \\
97\end{array}$ & $\begin{array}{l}77 \\
67 \\
78 \\
77\end{array}$ & $\begin{array}{r}0 \\
0 \\
102 \\
20\end{array}$ & $\begin{array}{r}4 \\
5 \\
11 \\
15\end{array}$ & $\begin{array}{l}4 \\
5 \\
8 \\
8\end{array}$ & $\begin{array}{r}0 \\
0 \\
3.0 \\
0.5\end{array}$ & $\begin{array}{r}47 \\
54 \\
106 \\
67\end{array}$ & $\begin{array}{l}47 \\
54 \\
57 \\
57\end{array}$ & $\begin{array}{r}0 \\
0 \\
7 \\
1.4\end{array}$ & $\begin{array}{l}17 \\
19 \\
53 \\
24\end{array}$ & $\begin{array}{l}17 \\
19 \\
21 \\
21\end{array}$ & $\begin{array}{r}9 \\
11 \\
2\end{array}$ & 1 \\
\hline
\end{tabular}


$\Delta$ 
PNL -3083

UC- 12

\section{DISTRIBUTION}

No. of

Copies

OFFSITE

R. F. Abbey, Jr.

Office of Nuclear Regulatory Research

U.S. Nuclear Regulatory Commission Washington, DC 20555

D. S. Ballentine

Office of Health \& Environmental Research

U.S. Department of Energy

Washington, DC 20545

M. Breig

Argonne National Laboratory

9700 South Cass Avenue

Argonne, IL 60439

G. A. Briggs (ATDL)

Oak Ridge National Laboratory

P.0. Box $Y$

Dak Ridge, TN 37830

T. G. Brna

Environmental Protection Agency

Research Triangle Park, NC 27711

J. E. Carson

Argonne National Laboratory

9700 South Cass Avenue

Argonne, IL 60439

N. C. J. Chen

Oak Ridge National Laboratory

P.0. Box $Y$

Oak Ridge, TN 37830

A. A. Churm

DOE Patent Division

9800 South Cass Avenue

Argonne, IL 60439
No. of

Copies

OFFSITE

J. H. Coleman

Air Quality Branch

Tennessee Valley Authority

River Oaks Building

Muscle Shoals, AL 35660

T. Crawford

Environmental Transport Division

Savannah River Laboratory

Aiken, SC 29801

27 DOE Technical Information Center

D. M. Eissenberg

B1dg. 9102-1

Oak Ridge National Laboratory

P.0. Box $Y$

Oak Ridge, TN 37830

F. A. Gifford (ATDL)

Oak Ridge National Laboratory

P.0. Box $Y$

Oak Ridge, TN 37830

C. Hakkarinen

Electric Power Research Institute

P.0. Box 10412

Palo Alto, CA 94303

S. R. Hanna (ATDL)

Oak Ridge National Laboratory

P.0. Box $Y$

Oak Ridge, TN 37830

P. Harrison

Meteorology Research, Inc.

P.0. Box 637

Altadena, CA 91001 
No. of

Copies

OFFSITE

B. B. Hicks

Argonne National Laboratory

9700 South Cass Avenue

Argonne, IL 60439

F. W. Hoffman

Calfran Industries

P.0. Box 269

Springfield, MA 01101

H. W. Hoffman

Oak Ridge National Laboratory

P.0. Box $Y$

Oak Ridge, TN 37830

J. D. Holmberg

Marley Cooling Tower Company

5800 Fox Ridge Drive

Mission, KS 66202

F. Huff

Illinois State Water Survey

P.0. Box 232

Urbana, IL 61801

J. Jansen

Southern Company Services, Inc. P.0. Box 2625

Birmingham, AL 35202

L. R. Koenig

Rand Corporation

1700 Ma in Street

Santa Monica, CA 90406

R. Kornasiewicz

Office of Standards Development

U.S. Nuclear Regulatory Commission

Washington, DC 20555
No. of

Copies

OFFSITE

Byron L. Marler

Pacific Gas \& Electric

245 Market Street

San Francisco, CA 94106

10 J. Maulbetsch

Electric Power Research Institute P.0. Box 10412

Palo A1to, CA 94303

J. H. Meyer

Applied Physics Laboratory

Johns Hopkins University

Laurel, MD 20810

3 Margaret Mooney

Pacific Gas \& Electric

245 Market Street

San Francisco, CA 94106

H. Moses

Office of Health \& Environmental

Research

U.S. Department of Energy

Washington, DC 20545

J. Motz

Georgia Power Company

P.0. Box 4545

Atlanta, FA 30302

F. W. Murray

Rand Corporation

1700 Main Street

Santa Monica, CA 90406

R. S. Nietubicz

Chalk Point Cooling Tower Project

c/o Bureau of Air Quality

\& Noise Control

0 'Conor Building

201 West Preston Street

Baltimore, MD 21201 
No. of

Copies

OFFSITE

J. M. Norman

Department of Meteorology

The Pennsylvania State University

University Park, PA 16802

T. J. Overcamp

Environmental Systems Engineering

Clemson University

Clemson, SC 29631

C. Paquin

Engineering Research

Pacific Gas \& Electric

3400 Crow Canyon Road

San Ramon, CA 94583

Shin Park

Oak Ridge National Laboratory

P.0. Box Y

Oak Ridge, TN 37830

5 A. A. N. Patrinos

B1dg. 9204-1, MS3

Oak Ridge National Laboratory

P.0. Box $Y$

Oak Ridge, TN 37830

J. Pell

Office of Environmental

Regulations

Federal Energy Administration

Room 7116

12th Street \& Pennsylvania Avenue Washington, DC 20461

J. Pena

Department of Meteorology

The Pennsylvania State University

University Park, PA 16802

R. Pena

Department of Meteorology

The Pennsylvania State University

University Park, PA 16802
No. of

Copies

OFFSITE

R. Perhac

Electric Power Research Institute P.0. Box 10412

Palo Alto, CA 94303

3 A. J. Policastro

Argonne National Laboratory

9700 South Cass Avenue

Argonne, IL 60439

G. Reynolds

Air Quality Assessment Section

River Oaks Bldg.

Muscle Shoals, AL 35660

A. Roffman

Energy Impact Associates

P.0. Box 1899

Pittsburg, PA 15230

15 A. Rubin

Advanced Nuclear Systems \&

Projects Division

U.S. Department of Energy

Washington, DC 20545

E. Ryzner

Department of Atmospheric \& Oceanic Science

University of Michigan

Ann Arbor, MI 48109

W. F. Savage

Advanced Nuclear Systems \& Projects Division

U.S. Department of Energy

Washington, DC 20545

3 H. W. Schmitt

Environmental Systems Corp.

P.0. Box 2525

Knoxville, TN 37901 
No. of

Copies

OFFSITE

G. 0. Schrecker

Science Applications Inc.

1651 01d Meadow Road

Suite 620

McLean, VA 22101

G. L. Sherwood

Office of Nuclear Energy Programs

U.S. Department of Energy

Washington, DC 20545

F. M. Shofner

Singing Hills Point

Knoxville, TN 37922

P. Slawson

Department of Mechanical

Engineering

University of Water 100

Waterloo, Ontario, Canada

D. W. Thomson

Department of Meteorology

The Pennsylvania State University

University Park, PA 16802

J. L. Voge1

Ill ino is State Water Survey

P.0. Box 232

Urbana, IL 61801

R. 0. Webb

Environmental Systems Corp.

P.0. Box 2525

Knoxville, TN 37901

M. L. Wesley

Argonne National Laboratory 9700 South Cass Avenue

Argonne, IL 60439
No. of

Copies

OFFSITE

K. 0. Wilber

Environmental Systems Corp.

P.0. Box 2525

Knoxville, TN 37901

L. Winiarski

Environmental Protection Agency

200 South 35th Street

Corvallis, OR 97330

G. J. Woffinden

Meteorology Research, Inc.

P.0. Box 637

Altadena, CA 91001

\section{ONSITE}

DOE Richland Operations Office

H. E. Ransom

60

Pacific Northwest Laboratory

T. J. Bander

W. C. Cliff

M. T. Dana

R. L. Drake

C. E. Elderkin

R. K. Hadlock

L. D. Kannberg

N. S. Laula inen (40)

Y. Onishi

M. M. Orgil1

J. V. Ramsde 11

J. M. Thorp

W. R. Wiley

R. K. Woodruff

Technical Information (5)

Publishing Coordination (2) 